CLARISSA FERREIRA DE MELO MESQUITA

\title{
O REGIME JURÍDICO DO SETOR POSTAL: DESAFIOS CONTEMPORÂNEOS E PERSPECTIVAS PARA O SETOR
}

DisSERTAÇão DE MESTRAdo

Orientador: Professor Dr. Floriano de AzeVedo Marques Neto

FACULDADE DE DIREITO DA UNIVERSIDADE DE SÃO PAULO SÃO PAULO 2012 
CLARISSA FERREIRA DE MELO MESQUITA

\section{O REGIME JURÍDICO DO SETOR POSTAL: DESAFIOS CONTEMPORÂNEOS E PERSPECTIVAS PARA O SETOR}

Dissertação apresentada à Faculdade de Direito da Universidade de São Paulo como requisito parcial para a obtenção do título de Mestre em Direito do Estado, na subárea Direito Administrativo, sob a orientação do Professor Dr. Floriano de Azevedo Marques Neto.

\section{SÃO PAULO}




\section{AGRADECIMENTOS}

Agradeço ao Professor Floriano DE AzEvedo MARQues Neto pelos ensinamentos, essenciais à minha formação, pelas oportunidades acadêmicas que tem me dado ao longo dos anos e pela cuidadosa orientação durante a elaboração desta dissertação de mestrado.

Aos Professores Diogo Rosenthal Coutinho e Fernando Dias Menezes de ALMEIDA, pelo rico diálogo, especialmente na banca de qualificação, e incentivo. Ao Professor DIOGO agradeço também pela contribuição que tem tido na minha formação acadêmica.

À Professora DinORÁ Adelaide Musetti GrotTi, que orientou meu trabalho de conclusão de curso da graduação, momento em que o tema do serviço postal surgiu como objeto de reflexão e pesquisa, pelo grande incentivo e leitura atenta de versão preliminar deste material.

À Professora Vera MonteIRo, exemplo de seriedade acadêmica, pela amizade, apoio e incentivo enormes, e leitura atenta de versão preliminar do texto.

Aos amigos e professores, leitores críticos, ANA LUCIA IKENAGA, ARgos Gregorio, Bruno Ramos Pereira (a quem agradeço especialmente), Carlos EduARdo Bergamini Cunha, Conrado Hübner Mendes, Guilherme Jardim Jurksaitis, Heitor Vitor Mendonça Sica, Jorge Antonio Dias Romero, Leo Meirelles do Amaral, Mateus Piva Adami, Rodrigo Pagani de Souza e Rodrigo Pinto de Campos, pelo diálogo constante e leitura atenta, em diferentes estágios da pesquisa, circunstâncias das quais advieram contribuições essenciais para o trabalho.

Aos Professores CARlos Ari Sundfeld e Jacintho ArRuda CÂmara, pela ajuda na viabilização de entrevistas (para a qual meu orientador FLORIANO DE AzEVEDO Marques Neto também foi essencial). Ao Professor CARlos ARI agradeço também por ter me auxiliado a dar os primeiros passos na vida acadêmica, trajetória da qual levo valores fundamentais e valiosos ensinamentos. Agradeço também pelo incentivo e apoio desde então. 
Ao Professor José Marcos LunARdelLI, pelo apoio e incentivo à realização deste trabalho, essenciais para conciliar sua elaboração com minha rotina profissional. Agradeço também aos colegas e amigos do Gabinete.

À Sociedade BRASILEIRA DE DiREITo Público, centro de debate e pesquisa que me inseriu no universo acadêmico do direito público e no qual desenvolvi grande parte da minha formação. Agradeço especialmente a ROBERTA SundFELd, pela amizade e incentivo, e a CONRADO HÜBNER MENDES, pela amizade, contribuição em minha formação acadêmica e por me abrir diversas oportunidades.

À MARINA RIBEIRO, cujo apoio emocional foi essencial para a realização deste trabalho.

A Roberto Melo Mesquita, pela leitura de várias versões deste texto, com a atenção própria a um pai. A Roberto, Sonia, Carolina, Tereza e Mateus, parte essencial de minha vida, agradeço pelo incentivo e apoio incondicionais. 
BANCA EXAMINADORA 


\section{RESUMO}

Este trabalho busca identificar os entraves e perplexidades jurídicas no setor postal - apontará as consequências da falta de clareza legislativa, doutrinária, jurisprudencial e regulatória no setor, aprofundando-se na análise de jurisprudência, especialmente do Supremo Tribunal Federal - chamando atenção para a possibilidade de serem adotadas novas soluções para resolvê-los.

O trabalho estrutura-se a partir de dois eixos intimamente relacionados: a) saber o que é serviço postal, qual é sua relevância na atual conjuntura das comunicações e qual é a realidade de prestação dos serviços nesse setor, objeto dos Capítulos 1 e 2, e b) desenvolver uma discussão crítica sobre serviço (público ou não) postal e "monopólio" postal, objeto do Capítulo 3 e núcleo central do trabalho. Ainda que o foco desta análise não seja a discussão mais ampla sobre a importância do planejamento e dos arranjos jurídico-institucionais do setor, procurar-se-á chamar atenção para esses aspectos no âmbito do setor postal.

A conclusão final da pesquisa, que confirma a hipótese central do trabalho, é a de que o regime jurídico do setor postal se constrói predominantemente a partir da atuação da ECT. O regime jurídico do setor tem sido delimitado a partir das políticas públicas voltadas à ECT, dos serviços postais por ela prestados e das decisões judiciais em que a estatal é autora ou ré, o que lhe confere um regime jurídico privilegiado e protetivo. A análise de todo esse arcabouço jurídico revela que, em grande medida, objetiva-se preservar a empresa pública ECT, em detrimento da avaliação do quadro maior do setor postal brasileiro. Esse entrave do setor leva à reflexão sobre a possibilidade de serem adotadas novas soluções para resolver os problemas setoriais, que podem abarcar desde soluções interpretativas a uma revisão do quadro normativo atualmente aplicável ao setor.

Palavras-chave: serviço postal, realidade do setor postal, natureza jurídica, "monopólio", jurisprudência, Supremo Tribunal Federal, ECT. 


\begin{abstract}
This dissertation aims to identify the legal obstacles and perplexities in the postal sector - will point the consequences of the lack of clarity of the legislative, doctrinal, case law and regulatory treatment of the sector, deepening the analysis of case law, especially of the Supreme Court - calling attention to the possibility of adopting new solutions to solve them.

The work is structured from two closely interconnected axes: a) one, to know what is the postal service, what is its relevance in the current communications, and the reality of service provision, the subject of Chapters 1 and 2; b) two, to develop a critical discussion about postal service (public or not) and post "monopoly", the subject of Chapter 3 and the central core of the work. Although the focus of this analysis does not correspond to the wider discussion about the importance of planning and of legal and institutional arrangements in the sector, this dissertation will seek to draw attention to these aspects within the postal sector.

The final conclusion of the study, which confirms the central hypothesis of the work, is that the legal system of the postal sector is built predominantly from the action of ECT. The legal system has been delimited from public policies to ECT, from the postal services it provides and from judicial decisions in which the public company is either plaintiff or defendant, and which gives to ECT a privileged and protective legal system. The analysis of all this legal framework reveals that, to a great extent, the objective is to preserve the public company ECT, rather than the evaluation of the bigger picture of the postal sector in Brazil. This obstacle of the sector leads to a reflection on the possibility of adopting new solutions to solve the problems, which can range from interpretative solutions to a review of the regulatory framework currently applicable to the sector.
\end{abstract}

Key-words: postal service, actually of the postal sector, legal nature, "monopoly", case law, Supreme Court, ECT. 


\section{SUMÁRIO}

II. METODOLOGIA ............................................................................................................ 15

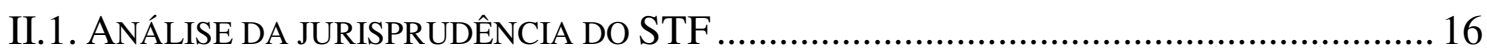

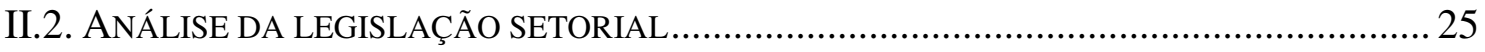

II.3. ANÁLISE DOS SERVIÇOS QUE A ECT PRESTA E DAS POLÍTICAS SOCIAIS DA EMPRESA 27

II.4. ENTREVISTAS 28

\section{CAPÍTULO 1 - REALIDADE DO SETOR POSTAL NO BRASIL ..................... 30}

III.1. CONSIDERAÇÕES HISTÓRICAS: UM BREVE PANORAMA DOS SERVIÇOS POSTAIS......... 30

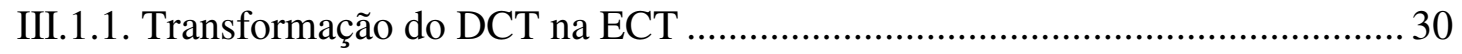

III.1.2. Realidade atual da prestação do serviço postal no Brasil ............................... 31

III.1.2.1. Ampliação dos serviços postais ............................................................. 32

III.1.2.2. Proliferação de prestadores no setor ..................................................... 33

III.2. SETOR POSTAL NO CENÁRIO ATUAL DAS COMUNICAÇÕES ...................................... 42

III.2.1. Déficit de regulação do setor postal: políticas públicas setoriais versus políticas da ECT e déficit de planejamento para o setor ....

III.2.2. Necessidade de um arranjo institucional: vetores que denotam a importância do setor. 49

III.2.2.1. Amplitude dos serviços postais ............................................................. 50

III.2.2.2. Empresa pública ECT: ações sociais e relevância econômica ................. 50

III.2.2.3. Capilaridade do serviço postal .......................................................... 53

\section{CAPÍTULO 2 - CONTEÚDO DOS SERVIÇOS POSTAIS ...................................55}

IV.1. DEFINIÇÃO DOS SERVIÇOS POSTAIS NA LEGISLAÇÃO POSTAL: DELIMITAÇÃO DOS SERVIÇOS COM FOCO NA ECT .....

IV.2. DISTANCIAMENTO DA LEI EM RELAÇÃO À REALIDADE DOS SERVIÇOS PRESTADOS PELA ECT: A CRIAÇÃO DE UMA VERDADEIRA REDE POSTAL .

IV.3. POSSIBILIDADE DE DIFERENCIAÇÃO DA REDE POSTAL POR FASES DO CICLO POSTAL OU POR SERVIÇOS

IV.4. DiVERSIDADE DE SERVIÇOS POSTAIS EM RELAÇÃO À ESSENCIALIDADE, CONTEÚDO ECONÔMICO E COMPETIÇÃO 
V.1. O SETOR POSTAL FRENTE À AVALIAÇÃO CRÍTICA SOBRE O REGIME JURÍDICO DOS SERVIÇOS PÚBLICOS .

V.1.1. O problema central da definição de serviço público 76

V.1.2. Pluralidade de regimes jurídicos dos serviços públicos.... 79

V.2. NATUREZA JURÍDICA DOS SERVIÇOS POSTAIS E A VALIDAÇÃO PELO STF DE UM REGIME JURÍDICO PROTETIVO À ECT .....

V.2.1. Panorama do serviço postal na Constituição Federal de 1988 e na legislação infraconstitucional. 80

V.2.1.1. Alcance do art. 21, X da Constituição . 80

V.2.1.2. Natureza jurídica de serviço público na lei $n^{\circ}{ }^{\circ}$ 9.074/95. 81

V.2.2. Uniformização da natureza jurídica do serviço postal pela doutrina brasileira e suas armadilhas 82

V.2.2.1. Elementos material e formal da noção de serviço público 82

V.2.2.2. Corrente majoritária: serviço postal como serviço público por definição constitucional e suas consequências 83

V.2.3. Análise crítica da judicialização dos privilégios da impenhorabilidade de bens e da imunidade tributária recíproca: as armadilhas da uniformização da natureza jurídica do serviço postal. 89

V.2.3.1. Delimitação incerta do conteúdo do serviço postal. 92

V.2.3.2. Necessidade de avaliação da função dos privilégios postais e impacto sobre a competição no setor. 100

V.2.3.3. Validação de um setor paralelo de prestadores 120

V.2.3.4. Impacto sobre as franquias postais ....

V.3. INTERDIÇÃO DOS PARTICULARES À PRESTAÇÃO DE PARTE DOS SERVIÇOS POSTAIS E A VALIDAÇÃO PELO STF DE UM REGIME JURÍDICO PROTETIVO À ECT .... 123

V.3.1. Discussão sobre a existência do "monopólio" postal constitucional 123

V.3.2. Distanciamento da lei n. ${ }^{\circ} 6.538 / 78$ em relação à realidade setorial e judicialização do privilégio do "monopólio" postal 128

V.3.3. Análise crítica da ADPF n. . 46-7: as armadilhas da recepção do "monopólio" postal 129

V.3.3.1. Delimitação incerta do campo de serviços não "monopolizados” .......... 132

V.3.3.2. Correlação entre serviço público e prestação "monopolista"...... 139

V.3.3.3. Correlação entre "monopólio" e universalização 142

V.3.3.4. Contradição entre a natureza jurídica de serviço público da rede postal e a decisão final da ADPF. 149

V.3.3.5. Desafio da proliferação de prestadores privados...... 156

V.3.3.6. Necessidade de avaliação da função do "monopólio" postal. 159

V.4. HETEROGENEIDADE DO CONTEÚdo DOS SERVIÇOS POSTAIS EM FACE DO REGIME JURÍDICO: POSSÍVEIS NÚCLEOS MATERIAIS DE SERVIÇOS PÚBLICOS NO SETOR POSTAL E O CENÁRIO PROPOSTO PELO PL N. ${ }^{\circ} 1.491 / 97$ 161

V.5. BREVE ANÁLISE DAS PERSPECTIVAS DE REESTRUTURAÇÃO DO SETOR POSTAL NO BRASIL 
VII. REFERÊNCIAS BIBLIOGRÁFICAS ................................................................... 186

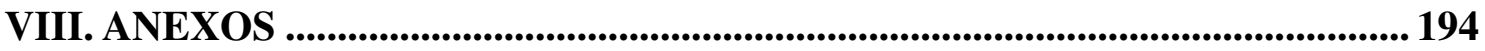
A. OS CASOS DA IMPENHORABILIDADE DOS BENS DA ECT 194
B. OS CASOS DA IMUNIDADE TRIBUTÁRIA RECÍPROCA.
C. O CASO DO “MONOPÓLIO” POSTAL (ADPF N. 46-7/DF) 220 


\section{INTRODUÇÃO}

A importância do estudo do tema regime jurídico do setor postal brasileiro está na insuficiência das soluções dadas aos problemas setoriais pela doutrina e jurisprudência frente aos novos desafios que o setor vem enfrentando.

Não seria retórico dizer que quase tudo no setor é questionável. O tema é marcado por uma grande carga ideológica, por fortes interesses políticos, pelos mais diversos interesses dos agentes econômicos que atuam no setor e juridicamente é envolto por um emaranhado de normas e decisões que muitas vezes são incapazes de regulamentar e regular o setor de maneira clara. No entanto, embora seja um campo importante e repleto de dificuldades, contraditoriamente vem sendo em grande medida negligenciado ${ }^{1}$, tanto na esfera de discussões políticas quanto na de discussões acadêmicas ${ }^{2}$.

Diante desse cenário, o presente estudo procura fazer um mergulho na especificidade do setor postal brasileiro, e, ao fazê-lo, recusa teorias generalizantes, que abstraem peculiaridades centrais para o tratamento e disciplina do setor. O objetivo que se busca no trabalho é pesquisar e revelar os problemas e gargalos jurídicos do setor e novas soluções para resolvê-los, que podem contribuir para uma possível revisão normativa e mesmo para aprimorar os debates e interpretações que envolvem o setor.

\footnotetext{
${ }^{1}$ Exemplifica esse cenário de negligência o déficit de regulação e a defasagem da legislação e de políticas públicas setoriais consistentes para o setor postal brasileiro, o que tem gerado vários problemas para a boa prestação dos serviços no Brasil, como se procurará argumentar ao longo desta dissertação. A título de exemplo, ao compararmos o setor postal a outros setores de infraestrutura, como telecomunicações, petróleo e energia elétrica, verificamos que as principais leis que regulamentam esses setores são da década de 1990 (lei n. ${ }^{\circ}$ 9.472/97, lei n. ${ }^{\circ}$ 9.478/97 e lei n. ${ }^{\circ}$ 9.427/96, respectivamente), enquanto que os principais instrumentos que regem o setor postal brasileiro são do final das décadas de 1960 e 1970 (decreto-lei n. ${ }^{\circ}$ 509/69 e lei n. ${ }^{\circ}$ 6.538/78).

${ }^{2}$ Bem é verdade que há trabalhos publicados que tratam especificamente do setor postal brasileiro, como a dissertação de mestrado de Maria Neuensjchwander Escosteguy Carneiro, posteriormente publicada, Uma nova visão do setor postal brasileiro; e a tese de doutorado de Ubirajara Costódio Filho, posteriormente publicada, $O$ serviço postal no direito brasileiro. Embora esses trabalhos sejam importantes para o debate a respeito do setor, creio que ainda há um grande campo de pesquisa e reflexão para os estudiosos do direito e formuladores de políticas públicas, para que, considerada a acentuada complexidade do regime jurídico atual do setor postal brasileiro, sejam formuladas contribuições sólidas para uma eventual reformulação do setor.
} 
As discussões a respeito do setor postal brasileiro referem-se em grande medida a definir qual é a natureza jurídica dos serviços postais, ficando num plano bastante secundário a questão central de saber o que é serviço postal (qual o núcleo material dos serviços), a realidade da prestação dos serviços (a complexidade dos serviços atualmente englobados como serviços postais e as diversas formas de sua prestação) e as consequências da legislação setorial e das decisões judiciais relacionadas ao setor.

Substancialmente, há hoje uma dificuldade bastante grande de se demarcar quais agentes econômicos podem atuar no setor (se as atividades postais podem ser prestadas por particulares através de concessões e permissões, se podem ser prestadas através de contratos de franquia ou se são livres à exploração privada, independentemente de qualquer vínculo de outorga) e mesmo de saber se o "monopólio" conferido à Empresa Brasileira de Correios e Telégrafos (ECT) pelo decreto-lei n. ${ }^{\text { }}$ 509/69 foi recepcionado pela atual Constituição Federal e, se foi, quais serviços estariam nele englobados. Atualmente, atuam no setor diversos agentes econômicos, sem se saber ao certo quais serviços podem prestar e se podem fazê-lo num regime de mercado.

Esse cenário tem gerado uma judicialização reiterada dos conflitos ${ }^{3}$, envolvendo a ECT, agências franqueadas e empresas de distribuição (as chamadas empresas de courier). Especificamente em relação à ECT essa judicialização reiterada relaciona-se também aos privilégios da impenhorabilidade de bens, rendas e serviços, da "imunidade" tributária ${ }^{4}$ e

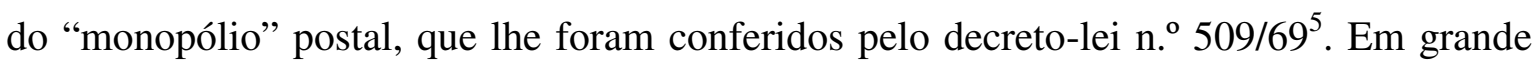

\footnotetext{
${ }^{3}$ A esse respeito, é importante notar que os números de conflitos que chegam ao Judiciário são grandes. A partir das expressões de pesquisa "ECT", "Empresa Brasileira de Correios e Telégrafos", "serviço e postal", "serviços e postais", "franquia e postal" e "franquias e postais", foram julgados ao todo, incluindo-se os casos repetidos, 328 acórdãos apenas no Supremo Tribunal Federal, entre os anos 1990 (inclusive) à data inicial de seleção dos acórdãos, em junho de 2010. Contra isso se pode argumentar que outras matérias geram maior quantidade de conflitos no Judiciário. Porém, a "grande judicialização" dos conflitos no setor postal não se reflete apenas em termos numéricos. Mais do que os números, o problema central da judicialização que se verifica no setor é o eterno retorno dos conflitos, a insuficiência das resoluções judiciais para colocar fim a eles.

${ }^{4}$ Embora o decreto-lei n. ${ }^{0}$ 509/69 confira expressamente à ECT o privilégio da imunidade tributária em seu art. 12, segundo os tributaristas, imunidade advém da própria Constituição, pelo que tecnicamente não existiria imunidade prevista em lei infraconstitucional. Assim, se a referida imunidade decorresse unicamente do decreto-lei seria na verdade uma isenção. Entretanto, como verificaremos na análise da jurisprudência relativa ao setor postal, o STF fundamenta as decisões sobre imunidade no art. 150, VI, "a" da Constituição, que trata da imunidade recíproca.

5 "Art. 12 - A ECT gozará de isenção de direitos de importação de materiais e equipamentos destinados aos seus serviços, dos privilégios concedidos à Fazenda Pública, quer em relação a imunidade tributária, direta ou indireta, impenhorabilidade de seus bens, rendas e serviços, quer no concernente a foro, prazos e custas processuais".
} 
medida, tem-se assistido a uma patente dificuldade de se definir o regime jurídico aplicável ao setor postal como um todo e o aplicável à sua principal prestadora, a ECT.

Mas é preciso escolher um eixo temático nesse universo tão abrangente. Assim, o presente estudo não se destina a teorizar sobre serviço público ou sobre o regime jurídico de sua exploração ou mesmo sobre a introdução de concorrência ao regime de serviço público, tampouco se procurará tratar com profundidade do regime jurídico de exploração das franquias postais (e como ele pode ser usado como forma de parceria com o poder público) ou mesmo dos contornos da atuação empresarial do Estado por meio da empresa pública ECT.

A hipótese central desse trabalho é que o regime jurídico do setor postal se constrói a partir da atuação da empresa estatal ECT mais do que de qualquer outro referencial. A pesquisa, assim, parte da hipótese, a ser testada ao longo do estudo, de que a disciplina jurídica do setor volta-se em grande medida à ECT, o que pode constituir um problema ao verificarmos que há outros agentes econômicos atuando no setor postal.

A pesquisa terá foco em diagnosticar os entraves e perplexidades jurídicas no setor - apontará as consequências da falta de clareza legislativa, doutrinária, jurisprudencial e regulatória no setor postal, aprofundando-se na análise de jurisprudência, especialmente do Supremo Tribunal Federal - chamando atenção para a possibilidade de serem adotadas novas soluções para resolvê-los. O trabalho estrutura-se a partir de dois eixos intimamente relacionados: a) saber o que é serviço postal, qual é sua relevância na atual conjuntura das comunicações e qual é a realidade de prestação dos serviços nesse setor, objeto dos Capítulos 1 e 2, e b) desenvolver uma discussão crítica sobre serviço (público ou não) postal e "monopólio" postal, objeto do Capítulo 3 e núcleo central do trabalho. Ainda que o foco desta análise não seja a discussão mais ampla sobre a importância do planejamento e dos arranjos jurídico-institucionais do setor, procurar-se-á chamar atenção para esses aspectos no âmbito do setor postal.

Com o intuito de descrever a realidade do setor postal no Brasil, o Capítulo 1 será iniciado com breves considerações históricas, identificando-se o momento do surgimento da ECT e as transformações mais recentes no setor, com a ampliação dos serviços postais e a proliferação de prestadores privados. Essa breve descrição histórica será seguida da identificação de um déficit de políticas públicas setoriais, dada a existência de políticas voltadas somente à empresa pública ECT. Imagina-se demonstrar que isso tem levado a um 
déficit de planejamento do setor como um todo, que necessita de um arranjo institucional adequado por ser um setor relevante para a economia nacional.

Em seguida, o Capítulo 2 terá por objetivo descrever o conteúdo dos serviços postais. Para tanto, o primeiro passo será expor como os serviços são definidos na legislação. $\mathrm{O}$ foco da análise será fundamentalmente a lei $\mathrm{n}^{\circ}{ }^{\mathrm{o}} 6.538 / 78$, que traz uma delimitação dos serviços destinada especificamente à ECT. O segundo passo será identificar o distanciamento dessa lei em relação à realidade dos serviços prestados no setor, tendo em vista a sua crescente complexidade, o que leva à necessidade de se perquirir quais são as atividades prestadas como postais. $\mathrm{O}$ objetivo será identificar os efeitos jurídicos derivados desse alargamento dos serviços postais. Imagina-se que se poderá demonstrar que os serviços postais se diferenciam pela essencialidade, por seu conteúdo econômico e sujeição à competição, havendo a possibilidade de a rede postal receber um tratamento jurídico distinto em razão dos serviços ou das fases do ciclo postal.

No Capítulo 3, inicialmente procurar-se-á investigar de maneira geral o que se considera "serviço público", buscando-se com isso avaliar os impactos da pluralidade de regimes de serviço público no setor postal. Em seguida, o estudo será destinado a identificar os limites constitucionais e legais do serviço postal, que dará suporte à análise crítica da natureza jurídica dos serviços postais na doutrina e na jurisprudência. Nesse momento será necessário identificar a construção da uniformização da natureza jurídica do serviço como serviço público, em grande medida relacionada à ECT, e as consequências que disso advêm.

Com isso, imagina-se poder demonstrar que a noção constitucional de serviço público mais atrapalha do que ajuda e que a ideia uniforme de que toda a rede postal é de serviço público, independentemente dos serviços que são prestados, cria diversos problemas no setor (a ideia de "armadilhas"). Além disso, utilizando-se das limitações constitucionais e legais existentes ao "monopólio" postal, serão mapeadas as consequências da recepção do "monopólio", tal como vem sendo construída pelo Supremo Tribunal Federal. 
Uma vez demonstradas a heterogeneidade do setor e a insuficiência de análises voltadas apenas ao texto constitucional, o capítulo será destinado a identificar núcleos materiais de serviços públicos, a partir da análise comparativa do modelo proposto no projeto de lei n. ${ }^{\circ}$ 1.491/97. Por fim, diante dos problemas e gargalos jurídicos identificados no setor, esse capítulo terá por objetivo chamar atenção para a importância do planejamento e dos arranjos jurídico-institucionais do setor. 


\section{METODOLOGIA}

Ao longo da elaboração da pesquisa, foram constatadas quatro dimensões problemáticas no setor: a dimensão normativa, a dimensão doutrinária, a dimensão jurisprudencial e a dimensão regulatória. Ao longo do trabalho serão revelados problemas nessas quatro dimensões: do ponto de vista normativo inexiste um marco legal adequado, do ponto de vista doutrinário e especialmente do jurisprudencial há quase que uma irracionalidade e do ponto de vista regulatório verifica-se a inexistência de uma estrutura regulatória minimamente adequada para um setor da relevância do postal. Por uma necessidade de recorte metodológico, o estudo será mais centrado em torno da análise crítica ao tratamento da doutrina e especialmente da jurisprudência ao setor postal.

O enfoque dado ao tema procurará combinar os tons descritivo e propositivo. Ora os argumentos serão apresentados descritivamente (especialmente nos primeiros dois capítulos), identificando-se como o setor funciona e qual a sua disciplina jurídica e construindo-se possíveis respostas sobre os gargalos do serviço público no direito brasileiro e interpretações sobre o que a nosso ver é mais adequado (o que pressupõe externar juízos valorativos), ora os argumentos avançarão provocativamente sob a forma de perguntas (especialmente no capítulo final), provocações que terão o objetivo de menos do que dar respostas, constranger, problematizar, instigar à reflexão os estudiosos do direito de maneira geral e doutrina e jurisprudência que enfrentam a questão do serviço público por intermédio do setor postal.

A proposta metodológica de abordagem ainda procurará combinar análises estruturais e análises funcionais, a partir da classificação proposta por Norberto Bobbio. Em diversos estudos, reunidos e publicados na obra editada no Brasil com o título $D a$ estrutura à função ${ }^{6}$, o autor chama atenção para o fato de que ainda hoje prevalece uma imagem tradicional do direito, de um ordenamento eminentemente repressivo. Ao lado dessa concepção repressiva do direito, o autor entende que deve somar-se uma nova imagem, do ordenamento com função promocional, capaz de direcionar comportamentos com vistas a atingir certos objetivos.

\footnotetext{
${ }^{6}$ Norberto Bobbio. Da estrutura à função: novos estudos de teoria do direito. Especificamente sobre esse tema, ver os estudos "A função promocional do direito", p. 1-21 e "Em direção a uma teoria funcionalista do direito", p. 53-79.
} 
Tomando por base essas duas imagens do direito trazidas por Bobbio, a pesquisa parte da ideia segundo a qual, seja da perspectiva repressiva, seja do ângulo promocional, o direito aplicável ao setor postal (a legislação setorial e as decisões judiciais) não tem cumprido de maneira eficiente sua função. Não tem conseguido reprimir os atos nocivos às regras legais (tanto assim que se assiste à proliferação de agentes econômicos que atuam nas áreas supostamente "monopolizadas" da ECT e mesmo a uma dificuldade de se definir o regime jurídico aplicável ao setor) e tampouco tem cumprido sua tarefa promocional, de estimular e promover atos socialmente desejáveis à boa prestação do serviço postal, orientados a partir das finalidades que se pretende atingir no setor. Essa concepção de Bobbio de que a análise do direito caminha do ângulo do funcionamento da estrutura do ordenamento jurídico em direção a uma análise da função do ordenamento será central na abordagem deste trabalho.

Embora os contornos gerais da metodologia de abordagem do material pesquisado já tenham sido apresentados, a seguir serão feitas algumas observações específicas relacionadas à análise do material objeto do trabalho: jurisprudência do STF, legislação setorial, serviços postais prestados pela ECT, políticas sociais da empresa e material coletado em entrevistas. Tendo em vista os diferentes pesos atribuídos a cada um desses objetos de pesquisa, apresentados na introdução deste trabalho, e o pressuposto segundo o qual essas fontes de pesquisa relacionam-se entre si, esses materiais serão estudados e referidos ao longo da dissertação sem que haja, no entanto, um capítulo próprio para cada um.

\section{II.1. Análise da jurisprudência do STF}

O estudo de casos, especialmente da linha de entendimento do Supremo Tribunal Federal (STF), terá um papel relevante na dissertação, uma vez que a pesquisa, por uma necessidade de recorte metodológico, será mais centrada em torno da análise crítica da jurisprudência relacionada ao setor postal. Pretende-se que a jurisprudência possibilite, desta forma, o grande mergulho vertical da pesquisa. Trata-se de uma forma de valorizar a jurisprudência como fonte do direito. Necessário frisar, no entanto, que embora a análise da jurisprudência tenha importância significativa no trabalho, objetiva-se analisar de maneira ampla o setor postal brasileiro, razão pela qual a pesquisa não se restringe ao estudo de casos do STF. 
A análise das decisões do STF se justifica em razão dos seguintes fatores: (a) a judicialização reiterada no STF dos conflitos que envolvem a ECT (a principal prestadora do setor) e os demais agentes econômicos que atuam no setor postal (empresas de courier e agências franqueadas); (b) a construção doutrinária e jurisprudencial do entendimento segundo o qual o regime jurídico das empresas estatais é diferente em razão da natureza jurídica dos serviços que prestam (se serviços públicos ou atividades econômicas), o que se pretende argumentar que é bastante discutível em razão da invalidade dessa distinção; (c) a natureza casuística das decisões do STF; (d) o profundo impacto que as decisões do STF têm na sociedade ${ }^{7}$; e (e) a escassez de literatura sobre o setor postal brasileiro.

Diante disso, em grande medida, conhecer o regime jurídico do setor postal brasileiro significa analisar como ele vem sendo criado na prática pelo STF. Ainda que a doutrina majoritariamente reconheça o serviço postal como serviço público, esse entendimento sobre a natureza jurídica do serviço (e, portanto, sobre a forma de sua prestação) não vincula os ministros a se pronunciarem nos casos concretos desta ou daquela maneira.

\footnotetext{
${ }^{7}$ A respeito do tema, ver Oscar Vilhena Vieira, Supremo Tribunal Federal: jurisprudência política, p. 228. Sobre o papel importante que as Cortes Constitucionais podem (e, acredito, ao menos deveriam) exercer de melhorar e qualificar os debates sobre temas importantes a respeito dos quais se pronunciam, e de fortalecer a participação popular, as regras do jogo democrático, ver também Jeremy Waldron, Law and Disagreement, p. 232-254 (cap. 11: "Participation: The Right of Rights").
} 
A pesquisa de jurisprudência foi realizada no site do STF, a partir dos links "jurisprudência"/"pesquisa". Foram utilizadas as seguintes expressões de busca: "ECT", "Empresa Brasileira de Correios e Telégrafos"9 "serviço $e$ postal",10, "serviços $e$ postais"11, "franquia $e$ postal"12 e "franquias $e$ postais"13.

$\mathrm{O}$ objeto da pesquisa restringiu-se aos acórdãos, às súmulas vinculantes e às súmulas, procurando-se com isso os pronunciamentos da instituição $\mathrm{STF}^{14}$. Dessa pesquisa inicial foram coletados 179 acórdãos da expressão de busca "ECT", 168 acórdãos da expressão de busca "Empresa Brasileira de Correios e Telégrafos", 31 acórdãos da expressão de busca "serviço e postal", 7 acórdãos da expressão de busca "serviços e postais", 2 da expressão "franquia e postal" e 0 (zero) da expressão "franquias e postais". Não foram encontradas súmulas e súmulas vinculantes.

Foi feita uma comparação inicial para verificação dos acórdãos iguais e um recorte temporal: a pesquisa foi limitada dos anos 1990 (inclusive) à data de seleção dos acórdãos, em junho de 2010 (pronunciamentos do Tribunal pós-Constituição Federal de 1988). Posteriormente, a pesquisa foi atualizada até dezembro de 2011.

Foi feita uma triagem inicial, na qual foram excluídos os acórdãos que tratavam de questões processuais (por exemplo, preparo, requisitos da petição inicial, tempestividade) ou que não guardavam relação com o objeto de análise (por exemplo, que tratavam da mudança de regime dos empregados do antigo Departamento de Correios e Telégrafos, que foi transformado na ECT, ou mesmo da competência da Justiça Federal para julgamento de ações e da competência privativa da União para legislar sobre serviço postal). Ao material

\footnotetext{
${ }^{8}$ Pesquisa realizada em 04.06.10 e atualizada em 21.12.2011. Disponível em: $<$ http://www.stf.jus.br/portal/jurisprudencia/listarJurisprudencia.asp?s1=ECT\&base=baseAcordaos $>$.

${ }^{9}$ Pesquisa realizada em 12.06.10 e atualizada em 21.12.2011. Disponível em: <http://www.stf.jus.br/portal/jurisprudencia/listarJurisprudencia.asp?s1=empresa\%20brasileira\%20de\%20cor reios $\% 20 \mathrm{e} \% 20$ telégrafos \&base=baseAcordaos $>$.

${ }^{10}$ Pesquisa realizada em 12.06.10 e atualizada em 21.12.2011. Disponível em: $<$ http://www.stf.jus.br/portal/jurisprudencia/listarJurisprudencia.asp?s1=servi\%E7o+e+postal\&base=baseAc ordaos $>$.

${ }^{11}$ Pesquisa realizada em 12.06.10 e atualizada em 21.12.2011. Disponível em: $<$ http://www.stf.jus.br/portal/jurisprudencia/listarJurisprudencia.asp?s 1=servi\%E7os+e+postais\&base=baseA cordaos $>$.

${ }^{12}$ Pesquisa realizada em 12.06.10 e atualizada em 21.12.2011. Disponível em: $<$ http://www.stf.jus.br/portal/jurisprudencia/listarJurisprudencia.asp?s1=franquia+e+postal\&base=baseAcord aos>.

${ }^{13}$ Pesquisa realizada em 12.06.10 e atualizada em 21.12.2011. A pesquisa não retornou nenhum acórdão.

${ }^{14}$ Não integraram a pesquisa as decisões monocráticas, decisões da Presidência, informativos e questões de ordem.
} 
coletado foram agregados eventuais acórdãos que não apareceram na expressão de busca, mas foram referidos em dissertações, livros, artigos e notícias de jornais.

A partir das mesmas palavras-chave e dos mesmos critérios de busca e seleção, integraram também o objeto de análise as repercussões gerais. Da pesquisa inicial foram coletados 3 acórdãos da expressão de busca "ECT", 3 acórdãos da expressão de busca "Empresa Brasileira de Correios e Telégrafos", 2 acórdãos da expressão de busca "serviço e postal", 0 (zero) acórdãos da expressão de busca "serviços e postais", 0 (zero) da expressão "franquia e postal" e 0 (zero) da expressão "franquias e postais". Foram analisadas ao longo do trabalho a Repercussão Geral em Recurso Extraordinário n. ${ }^{\circ}$ 601.392/PR, e a Repercussão Geral no Recurso Extraordinário n. ${ }^{\circ}$ 627.051/PE. Em ambos os casos, o Tribunal reconheceu a existência de repercussão geral da questão constitucional suscitada, ambas relacionadas ao tema da imunidade tributária, o que pode gerar em breve pronunciamentos da instituição STF sobre questões relevantes sobre o tema.

À seleção de acórdãos foi também agregada a análise dos seguintes materiais:

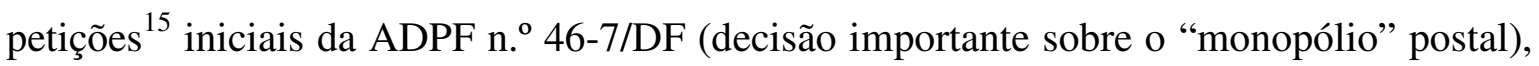
dos embargos de declaração opostos contra esta decisão e da ADI n. ${ }^{\circ}$ 4.155-0/DF (pela qual o Procurador-Geral da República questionou o regime de franquias postais); e da decisão monocrática STA n. ${ }^{\circ}$ 335/DF (proferida pelo ministro Gilmar Mendes quando surgiram especulações de que a substituição dos contratos de franquia celebrados sem prévia licitação poderia colocar em risco a adequada prestação dos serviços).

A partir dessa triagem inicial, verificou-se que os pronunciamentos do Tribunal relacionam-se fundamentalmente a dois assuntos: a impenhorabilidade dos bens da ECT e à imunidade tributária recíproca, privilégios que foram garantidos à estatal pelo decreto-lei n. ${ }^{\circ}$ 509/69, responsável por sua criação.

${ }^{15}$ As petições estão disponíveis no site do STF - link "processos", "acompanhamento processual". 
A respeito da impenhorabilidade de bens, foram analisados os seguintes acórdãos:

Recurso Extraordinário n. ${ }^{\circ}$ 222.041-5/RS - Rio Grande do Sul. Relator: Min. Ilmar Galvão. Julgamento: 15/09/1998. Órgão julgador: Primeira Turma. Recorrente: ECT. Recorrida: Maria Eva Goudinho Souza.

Recurso Extraordinário n. ${ }^{\circ}$ 220.906-9/DF - Distrito Federal. Relator: Min. Maurício Corrêa. Julgamento: 16/11/2000. Órgão julgador: Tribunal Pleno. Recorrente: ECT. Recorrido: Ismar José da Costa.

Recurso Extraordinário n. ${ }^{\circ}$ 225.011/MG - Minas Gerais. Relator: Min. Marco Aurélio. Redator para o acórdão: Min. Maurício Corrêa. Julgamento: 16/11/2000. Órgão julgador: Tribunal Pleno. Recorrente: ECT. Recorrido: Claudio Rodrigues dos Santos.

Recurso Extraordinário n. ${ }^{\circ}$ 229.696-7/PE - Pernambuco. Relator: Min. Ilmar Galvão. Redator para o acórdão: Min. Maurício Corrêa. Julgamento: 16/11/2000. Órgão julgador: Tribunal Pleno. Recorrente: ECT. Recorrido: Edgar Henrique da Silva.

Recurso Extraordinário n. ${ }^{\circ}$ 230.072-3/RS - Rio Grande do Sul. Relator: Min. Ilmar Galvão. Redator para o acórdão: Min. Maurício Corrêa. Julgamento: 16/11/2000. Órgão julgador: Tribunal Pleno. Recorrente: ECT. Recorrida: Sônia Elda Ostrowski da Rosa.

Recurso Extraordinário n. ${ }^{\circ}$ 230.051-6/SP - São Paulo. Emb. Decl. no Recurso Extraordinário. Relator: Min. Maurício Corrêa. Julgamento: 16/11/2000. Órgão julgador: Tribunal Pleno. Embargante: Carlos Roberto Bonjorni e outro(a/s). Embargada: ECT.

Recurso Extraordinário n. ${ }^{0}$ 220.699-3/SP - São Paulo. Relator: Min. Moreira Alves. Julgamento: 12/12/2000. Órgão julgador: Primeira Turma. Recorrente: ECT. Recorrido: Carlos Roberto Bonjorni.

Recurso Extraordinário n. 229.961-2/MG - Minas Gerais. Relator: Min. Moreira Alves. Julgamento: 12/12/2000. Órgão julgador: Primeira Turma. Recorrente: ECT. Recorrido: Henrique Miranda Sá Andrade.

Agr. Regimental no Recurso Extraordinário n. ${ }^{\circ}$ 230.161-6/CE - Ceará. Relator: Min. Néri da Silveira. Julgamento: 17/04/2001. Órgão julgador: Segunda Turma. Agravante: Município de Fortaleza. Agravada: ECT.

Recurso Extraordinário n. ${ }^{\circ}$ 220.907-5/RO - Rondônia. Relator: Min. Carlos Velloso. Julgamento: 12/06/2001. Órgão julgador: Segunda Turma. Recorrente: ECT. Recorrido: Raimundo Pereira Lira.

Recurso Extraordinário n. ${ }^{0}$ 229.444-8/CE - Ceará. Relator: Min. Carlos Velloso. Julgamento: 19/06/2001. Órgão julgador: Segunda Turma. Recorrente: Município de Fortaleza. Recorrida: ECT.

Edcl. no Agrg. no Recurso Extraordinário n. ${ }^{\circ}$ 204.635-3/RS - Rio Grande do Sul. Relator: Min. Maurício Corrêa. Julgamento: 26/06/2001. Órgão julgador: Segunda Turma. Embargante: Camilo Trindade Oleques. Embargada: ECT. 
Agrg. no Agravo de Instrumento n. 313.854-0/CE - Ceará. Relator: Min. Néri da Silveira. Julgamento: 25/09/2001. Órgão julgador: Segunda Turma. Agravante: Município de Fortaleza. Agravada: ECT.

Agrg. no Recurso Extraordinário n. ${ }^{\circ}$ 265.139-7/RS - Rio Grande do Sul. Relatora: Min. Ellen Gracie. Julgamento: 05/02/2002. Órgão julgador: Primeira Turma. Agravante: Joceni Santarém da Silva. Agravada: ECT.

Recurso Extraordinário n. ${ }^{\circ}$ 336.685-8/MG - Minas Gerais. Relator: Min. Moreira Alves. Julgamento: 12/03/2002. Órgão julgador: Primeira Turma. Recorrente: ECT. Recorrido: José Rogério Giudice.

Edcl. no Recurso Extraordinário n. ${ }^{\circ}$ 220.902-3/PE - Pernambuco. Relator: Min. Moreira Alves. Julgamento: 12/03/2002. Órgão julgador: Primeira Turma. Embargante: Edgar Henrique da Silva. Embargada: ECT.

Edcl. no Agravo de Instrumento n. 363.017-1/SP - São Paulo. Relatora: Min. Ellen Gracie. Julgamento: 21/05/2002. Órgão julgador: Primeira Turma. Embargante: Estevão de Souza Melo. Embargado: ECT.

Agravo Regimental em Petição n. 2.677-2/PI - Piauí. Relator: Min. Moreira Alves. Julgamento: 10/09/2002. Órgão julgador: Primeira Turma. Agravante: Sindicato dos Trabalhadores dos Correios e Telégrafos do Estado do Piauí - SINTEC. Agravada: ECT.

Emb. Decl. no Recurso Extraordinário n. ${ }^{\circ}$ 230.051-6/SP - São Paulo. Relator: Min. Maurício Corrêa. Julgamento: 11/06/2003. Órgão julgador: Tribunal Pleno. Embargante: Carlos Roberto Bonjorni e outro(a/s). Embargada: ECT.

Emb. Decl. no Agravo de Instrumento n. ${ }^{0}$ 410.330-0/SP - São Paulo. Relator: Min. Nelson Jobim. Julgamento: 14/10/2003. Órgão julgador: Segunda Turma. Embargante: Luiz Otávio Salustiano da Silva. Embargada: ECT.

Ag. Reg. no Agravo de Instrumento n. ${ }^{\circ}$ 243.250-6/RS - Rio Grande do Sul. Relator: Min. Sepúlveda Pertence. Julgamento: 10/02/2004. Órgão julgador: Primeira Turma. Agravantes: Juvêncio José Faria e outro. Agravada: ECT.

Ag. Reg. no Agravo de Instrumento n.. 238.960-0/RS - Rio Grande do Sul. Relator: Min. Cezar Peluso. Julgamento: 06/09/2005. Órgão julgador: Primeira Turma. Agravante: Frederico Carlos Matte Neto. Agravada: ECT.

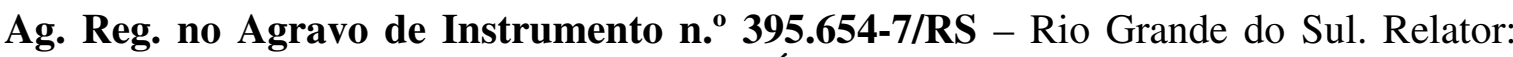
Min. Cezar Peluso. Julgamento: 14/02/2006. Órgão julgador: Primeira Turma. Agravante: Lindomar Lopes Romero. Agravada: ECT.

Ag. Reg. no Recurso Extraordinário n..$^{344.975-3 / R J ~-~ R i o ~ d e ~ J a n e i r o . ~ R e l a t o r: ~ M i n . ~}$ Gilmar Mendes. Julgamento: 29/11/2005. Órgão julgador: Segunda Turma. Agravante: Osmar Ferreira Amâncio. Agravada: ECT. 
Sobre a imunidade tributária recíproca, foram analisados os seguintes acórdãos:

Recurso Extraordinário n. ${ }^{\circ}$ 407.099-5/RS - Rio Grande do Sul. Relator: Min. Carlos Velloso. Julgamento: 22/06/2004. Órgão julgador: Segunda Turma. Recorrente: ECT. Recorrido: Município de São Borja.

Recurso Extraordinário n. ${ }^{\circ}$ 356.122-7/RS - Rio Grande do Sul. Relator: Min. Carlos Velloso. Julgamento: 17/08/2004. Órgão julgador: Segunda Turma. Recorrente: ECT. Recorrido: Município de Alegrete.

Recurso Extraordinário n. ${ }^{\circ}$ 354.897-2/RS - Rio Grande do Sul. Relator: Min. Carlos Velloso. Julgamento: 17/08/2004. Órgão julgador: Segunda Turma. Recorrente: ECT. Recorrido: Município de Montenegro.

Recurso Extraordinário n. ${ }^{\circ}$ 398.630-9/SP - São Paulo. Relator: Min. Carlos Velloso. Julgamento: 17/08/2004. Órgão julgador: Segunda Turma. Recorrente: ECT. Recorrido: Município de Estrela D’Oeste.

Recurso Extraordinário n. ${ }^{\mathbf{4}}$ 424.227-3/SC - Santa Catarina. Relator: Min. Carlos Velloso. Julgamento: 24/08/2004. Órgão julgador: Segunda Turma. Recorrente: ECT. Recorrido: Município de Imbituba.

Recurso Extraordinário n. ${ }^{\circ}$ 428.821-4/SP - São Paulo. Relator: Min. Carlos Velloso. Julgamento: 21/09/2004. Órgão julgador: Segunda Turma. Recorrente: ECT. Recorrido: Município de São Paulo.

Recurso Extraordinário n. ${ }^{\circ}$ 364.202-2/RS - Rio Grande do Sul. Relator: Min. Carlos Velloso. Julgamento: 05/10/2004. Órgão julgador: Segunda Turma. Recorrente: ECT. Recorrido: Município de Viamão.

Recurso Extraordinário n. ${ }^{\mathbf{4}}$ 437.889-2/RS - Rio Grande do Sul. Relator: Min. Carlos Velloso. Julgamento: 14/12/2004. Órgão julgador: Segunda Turma. Recorrente: ECT. Recorrido: Município de Porto Alegre.

Ag. Reg. no Recurso Extraordinário n. 328.843-1/MG - Minas Gerais. Relator: Min. Carlos Britto. Julgamento: 24/05/2005. Órgão julgador: Primeira Turma. Agravante: Estado de Minas Gerais. Agravado: ECT.

Ag. Reg. no Recurso Extraordinário n. ${ }^{\circ}$ 357.291-1/PR - Paraná. Relator: Min. Cezar Peluso. Julgamento: 09/05/2006. Órgão julgador: Primeira Turma. Agravante: Estado do Paraná. Agravado: ECT.

Ag. Reg. na Ação Cível Originária n. 789-2/PI - Piauí. Relator originário: Min. Marco Aurélio. Relator para o acórdão: Min. Joaquim Barbosa. Julgamento: 05/10/2006. Órgão julgador: Tribunal Pleno. Agravante: ECT. Agravado: Estado do Piauí.

Ag. Reg. na Ação Cível Originária n. ${ }^{\circ}$ 814-7/PR - Paraná. Relator originário: Min. Marco Aurélio. Relator para o acórdão: Min. Joaquim Barbosa. Julgamento: 05/10/2006. Órgão julgador: Tribunal Pleno. Agravante: ECT. Agravado: Estado do Paraná. 
Ag. Reg. na Ação Cível Originária n. ${ }^{\circ}$ 765-1/RJ - Rio de Janeiro. Relator originário: Min. Marco Aurélio. Relator para o acórdão: Min. Joaquim Barbosa. Julgamento: 05/10/2006. Órgão julgador: Tribunal Pleno. Agravante: ECT. Agravado: Estado do Rio de Janeiro.

Ag. Reg. na Ação Cível Originária n. ${ }^{\circ}$ 811-5/DF - Distrito Federal. Relator: Min. Gilmar Mendes. Julgamento: 26/04/2007. Órgão julgador: Tribunal Pleno. Agravante: Distrito Federal. Agravado: ECT.

Ag. Reg. na Tutela Antecipada na Ação Cível Originária n. ${ }^{\circ}$ 912-8/MS - Mato Grosso. Relator: Min. Ricardo Lewandowski. Julgamento: 22/11/2007. Órgão julgador: Tribunal Pleno. Agravante: Estado de Mato Grosso do Sul. Agravado: ECT.

Ag. Reg. na Medida Cautelar na Ação Cível Originária n. ${ }^{\circ}$ 1.095-6/GO - Goiás. Relator: Min. Gilmar Mendes. Julgamento: 17/03/2008. Órgão julgador: Tribunal Pleno. Agravante: Estado de Goiás. Agravado: ECT.

Ação Cível Originária n. ${ }^{\circ}$ 959-4/RN - Rio Grande do Norte. Relator: Min. Menezes Direito. Julgamento: 17/03/2008. Órgão julgador: Tribunal Pleno. Autor: ECT. Réu: Estado do Rio Grande do Norte.

Ag. Reg. no Agravo de Instrumento n. ${ }^{0}$ 718.646-1/SP - São Paulo. Relator: Min. Eros Grau. Julgamento: 16/09/2008. Órgão julgador: Segunda Turma. Agravante: Município de Santos. Agravado: ECT.

Ag. Reg. no Agravo de Instrumento n. ${ }^{\circ}$ 690.242-0/SP - São Paulo. Relator: Min. Ricardo Lewandowski. Julgamento: 17/03/2009. Órgão julgador: Primeira Turma. Agravante: Município de Santos. Agravado: ECT.

Ag. Reg. na Ação Cautelar n. ${ }^{0}$ 2.324-6/RS - Rio Grande do Sul. Relator: Min. Joaquim Barbosa. Julgamento: 12/05/2009. Órgão julgador: Segunda Turma. Agravante: Bela Vista Comércio de Produtos e Serviços Postais Ltda. Agravado: Município de Porto Alegre.

Ação Cível Originária n. ${ }^{\mathbf{7}} \mathbf{7 6 5 - 1 / R J}$ - Rio de Janeiro. Relator originário: Min. Marco Aurélio. Relator para o acórdão: Min. Menezes Direito. Julgamento: 13/05/2009. Órgão julgador: Tribunal Pleno. Autor: ECT. Réu: Estado do Rio de Janeiro.

Ag. Reg. no Agravo de Instrumento n. ${ }^{0}$ 748.076/MG - Minas Gerais. Relatora: Min. Cármen Lúcia. Julgamento: 20/10/2009. Órgão julgador: Primeira Turma. Agravante: Município de Belo Horizonte. Agravado: ECT.

Ag. Reg. no Recurso Extraordinário n. ${ }^{\circ}$ 552.736/RS - Rio Grande do Sul. Relatora: Min. Cármen Lúcia. Julgamento: 20/10/2009. Órgão julgador: Primeira Turma. Agravante: Município de Porto Alegre. Agravado: ECT.

Ag. Reg. no Agravo de Instrumento n. ${ }^{\circ}$ 518.325/RS - Rio Grande do Sul. Relator: Min. Joaquim Barbosa. Julgamento: 06/04/2010. Órgão julgador: Segunda Turma. Agravante: Município de São Leopoldo. Agravado: Estado do Rio Grande do Sul. 
Ag. Reg. no Recurso Extraordinário n. ${ }^{\circ}$ 443.648/RS - Rio Grande do Sul. Relator: Min. Joaquim Barbosa. Julgamento: 20/04/2010. Órgão julgador: Segunda Turma. Agravante: Município de Porto Alegre. Agravado: ECT.

Ação Cível Originária n. ${ }^{\mathbf{7}}$ 789/PI - Piaú. Relator: Min. Marco Aurélio. Relator para o Acórdão: Min. Dias Toffoli. Julgamento: 01/09/2010. Órgão Julgador: Tribunal Pleno.

Ag. Reg. na Ação Cível Originária n. ${ }^{\circ}$ 819/SE - Sergipe. Relator: Min. Dias Toffoli. Julgamento: 17/11/2011. Órgão julgador: Tribunal Pleno.

Repercussão Geral em Recurso Extraordinário n. ${ }^{\circ} 601.392$ - Paraná. Relator: Min. Joaquim Barbosa. Decisão: 02/11/2009. Recorrente: ECT. Recorrido: Município de Curitiba.

Repercussão Geral no Recurso Extraordinário n. ${ }^{0}$ 627.051/PE - Pernambuco. Relator: Min. Dias Toffoli. Decisão: 26/05/2011. Recorrente: ECT. Recorrido: Estado de Pernambuco.

Ao longo da dissertação foram analisados esses casos e também os pronunciamentos da Corte agregados à pesquisa inicial (referidos acima), cujas referências integrais são as seguintes:

Petição inicial da ADPF n. ${ }^{\circ}$ 46-7/DF, ajuizada pela Associação Brasileira das Empresas de Distribuição - ABRAED em 14 de novembro de 2003.

Petição de oposição de embargos de declaração, opostos pela ABRAED em 05 de março de 2010, contra a decisão da ADPF n. ${ }^{\circ}$ 46-7/DF.

Arguição de Descumprimento de Preceito Fundamental n. ${ }^{\circ}$ 46-7 - Distrito Federal. Relator originário: Min. Marco Aurélio. Relator para o acórdão: Min. Eros Grau. Julgamento: 05/08/2009. Órgão julgador: Tribunal Pleno. Arguente: ABRAED Associação Brasileira das Empresas de Distribuição.

Petição inicial da Ação Direta de Inconstitucionalidade n. ${ }^{\circ}$ 4.155-0/DF, ajuizada pelo Procurador-Geral da República em 06 de outubro de 2008.

Suspensão de Tutela Antecipada - STA n. ${ }^{\circ}$ 335/DF. Decisão monocrática. Relator: Ministro Presidente Gilmar Mendes. Julgamento: 12/06/2009. 
Ao longo da dissertação, especialmente de seu terceiro capítulo, procurar-se-á analisar os acórdãos e os demais materiais acima referidos expondo sua fundamentação (o que é especialmente relevante quando os ministros procuram diferenciar as atividades integrantes da rede postal e quem está prestando os serviços) e não apenas retratando o resultado do julgamento. Objetiva-se com isso retratar e analisar criticamente os debates existentes no Tribunal sobre o setor postal (inclusive do ponto de vista da consistência e coerência decisórias) e não apenas dar um "placar" de julgamento, que muitas vezes acaba perdendo as especificidades com que cada um dos ministros analisou as questões colocadas em pauta e os debates que estão por trás dos resultados.

Em Anexo a esta dissertação (item VIII) é apresentado o relato dos acórdãos do STF que subsidiaram a elaboração desta pesquisa, especialmente de seu terceiro capítulo. Para se dar uma ideia mais clara, e ao mesmo tempo sintética, de como decidiu o STF, procurou-se relatar os casos e, especialmente nos acórdãos de maior complexidade, agrupar as argumentações semelhantes dos ministros, o que se denominou de "linhas decisórias". Trata-se de resumo pormenorizado das principais razões de decidir dos ministros do STF em cada um dos casos concretos que compuseram a análise de jurisprudência realizada. As principais conclusões extraídas desse resumo e os principais debates nele referidos subsidiaram a redação e análise do Capítulo 3.

\section{II.2. Análise da legislação setorial}

A legislação aplicável ao setor postal foi mapeada a partir dos sites da $\mathrm{ECT}^{16}$ e do Ministério das Comunicações ${ }^{17}$. Foram lidas e estudadas as normas apresentadas abaixo. Do ponto de vista da normatividade, a presente pesquisa não se propõe a aprofundar a análise de todas as leis e demais normas que compõem o quadro da legislação setorial. A análise da legislação setorial, no entanto, justifica-se por ser elemento essencial para se obter um conhecimento aprofundado do setor, e para se avaliar se ela está em harmonia com sua estrutura regulatória, se ela está ou não adequada para um setor da relevância do postal, e tendo em vista suas especificidades (que dizem respeito, por exemplo, à delimitação dos serviços prestados como postais, que é apresentada na legislação, e às ações sociais da ECT).

\footnotetext{
${ }^{16}<$ http://www.correios.com.br/institucional/conheca_correios/conheca.cfm>.

$17<$ http://www.mc.gov.br/servicos-postais $>$.
} 


\section{Leis}

Decreto-lei n. ${ }^{\circ}$ 509, de 20 de março de 1969, Decreto-lei n. ${ }^{\circ}$ 538, de 17 de abril de 1969, Lei n. ${ }^{\circ} 6.538$, de 22 de junho de 1978, Lei n. ${ }^{\circ} 10.577$, de 27 de novembro de 2002, Lei n. ${ }^{\circ}$ 10.753, de 30 de outubro de 2003, Lei n. ${ }^{\circ} 11.282$, de 23 de fevereiro de 2006, Lei n. ${ }^{\circ}$ 11.668, de 02 de maio de 2008

\section{Projetos de Leis}

Projeto de lei n. ${ }^{\circ} 1.491$, de 1999

\section{Decretos}

Decreto n. ${ }^{\circ} 83.726$, de 17 de julho de 1979, Decreto n. ${ }^{\circ} 84.774$, de 06 de junho de 1980 , Decreto legislativo n..$^{\circ} 04$, de 02 de maio de 1985, Decreto n. ${ }^{\circ} 97.486$, de $1^{\circ}$ de fevereiro de 1989, Decreto n. ${ }^{\circ} 1.390$, de 10 de fevereiro de 1995, Decreto legislativo n. ${ }^{\circ} 86$, de 12 de junho de 1995, Decreto legislativo n. ${ }^{\circ} 119$, de 28 de setembro de 1995, Decreto n. ${ }^{\circ}$ 1.687, de 06 de novembro de 1995, Decreto n. ${ }^{\circ}$ 2.326, de 19 de setembro de 1997, Decreto n. ${ }^{\circ} 4.566$, de $1^{\circ}$ de janeiro de 2003, Decreto n. ${ }^{\circ}$ 5.220, de 30 de setembro de 2004, Decreto n. ${ }^{\circ}$ 5.672, de 11 de janeiro de 2006, Decreto n. ${ }^{\circ}$ 6.639, de 07 de novembro de 2008, Decreto legislativo n. ${ }^{\circ} 265$, de 2008, Decreto legislativo n. ${ }^{\circ} 285$, de 2008, Decreto n. ${ }^{\circ}$ 7.483, de 16 de maio de 2011

\section{Portarias}

Portaria n. ${ }^{\circ}$ 301, de 03 de abril de 1975, Portaria n. ${ }^{\circ}$ 322, de 16 de março de 1976, Portaria n..$^{\circ} 1.351$, de 21 de dezembro de 1978, Portaria n. ${ }^{\circ} 117$, de 28 de novembro de 1985, Portaria n. ${ }^{\circ} 245$, de 09 de outubro de 1995, Portaria n. ${ }^{\circ} 818$, de 17 de julho de 1996, Portaria n. $^{\circ} 1.961$, de 06 de dezembro de 1996, Portaria n. ${ }^{\circ} 152$, de 09 de julho de 1997, Portaria n. ${ }^{\circ}$ 371, de 10 de julho de 1997, Portaria n. ${ }^{\circ} 141$, de 28 de abril de 1998, Portaria n. ${ }^{\circ} 310$, de 18 de dezembro de 1998, Portaria n. ${ }^{\circ} 311$, de 18 de dezembro de 1998, Portaria n..$^{\circ} 01$, de 15 de janeiro de 1999, Portaria n. ${ }^{\circ} 150$, de 09 de setembro de 1999, Portaria n. ${ }^{\circ} 588$, de 04 de outubro de 2000, Portaria n. ${ }^{\circ} 589$, de 04 de outubro de 2000, Portaria n. ${ }^{\circ} 710$, de 20 de novembro de 2000, Portaria n. ${ }^{\circ} 819$, de 28 de dezembro de 2000, Portaria n. ${ }^{\circ} 203$, de 10 de julho de 2001, Portaria n. ${ }^{\circ} 386$, de 17 de julho de 2001, Portaria n. ${ }^{\circ} 01$, de 23 de outubro de 2001, Portaria n. ${ }^{\circ}$ 804, de 20 de dezembro de 2001, Portaria n. ${ }^{\circ}$ 251, de 06 de março de 2002, Portaria n. ${ }^{\circ} 250$, de 30 de abril de 2002, Portaria n. ${ }^{\circ} 518$, de 02 de outubro de 2003, Portaria n. ${ }^{\circ} 329$, de 02 de setembro de 2004, Portaria n. ${ }^{\circ}$ 500, de 06 de dezembro de 2004, Portaria n. ${ }^{\circ}$ 500, de 08 de novembro de 2005, Portaria n. ${ }^{\circ} 401$, de 22 de agosto de 2006, Portaria n. ${ }^{\circ} 55$, de $1^{\circ}$ de fevereiro de 2007, Portaria n. ${ }^{\circ} 296$, de 15 de junho de 2007, Portaria n. ${ }^{\circ}$ 694, de 13 de dezembro de 2007, Portaria n. ${ }^{\circ}$ 293, de 10 de junho de 2008, Portaria n. ${ }^{\circ}$ 294, de 10 de junho de 2008, Portaria . $^{\circ} 400$, de 22 de junho de 2009, Portaria n. ${ }^{\circ} 1.061$, de 29 de dezembro de 2009, Portaria n. ${ }^{\circ} 1.062$, de 29 de dezembro de 2009 


\begin{tabular}{|c|}
\hline Medidas provisórias \\
\hline Medida provisória n. ${ }^{\circ} 403$, de 26 de novembro de 2007 \\
\hline Medida provisória n. ${ }^{\circ}$ 509, de 13 de outubro de 2010 \\
\hline Medida provisória n. ${ }^{\circ} 532$, de 28 de abril de 2011 \\
\hline
\end{tabular}

\section{Instruções normativas}

Instrução normativa n. ${ }^{\circ}$, de 28 de abril de 1999 , Instrução normativa n. $^{\circ} 1$, de 14 de dezembro de 2000, Instrução normativa n. ${ }^{\circ} 1$, de 25 de julho de 2001, Instrução normativa n. ${ }^{\circ} 2$, de 25 de julho de 2001

\section{Despachos do Presidente da República}

Mensagem n. ${ }^{\circ} 245$, de 02 de maio de 2008

\section{Acordos de cooperação}

Acordo de cooperação técnica - 2009; $10^{\circ}$ termo aditivo ao acordo de cooperação técnica; ajuste complementar Brasil-Paraguai.

\section{II.3. Análise dos serviços que a ECT presta e das políticas sociais da empresa}

Em razão da complexidade atual da rede postal e da incapacidade da legislação em precisar quais serviços integram essa rede, foram mapeados os serviços que vêm sendo oferecidos pela ECT, bem como as políticas sociais por ela desempenhadas, como empresa pública.

O mapeamento dos serviços postais a partir da ECT tem os seguintes fundamentos: (i) tem-se como hipótese de pesquisa, a ser testada, que o regime jurídico dos serviços postais tem se construído fundamentalmente a partir da atuação da ECT; (ii) a estatal é a principal prestadora dos serviços no Brasil; e (iii) seria inviável do ponto de vista prático averiguar de modo aprofundado todos os serviços ofertados pelas prestadoras de serviços postais. 
O mapeamento dos serviços prestados pela estatal foi realizado a partir do site da empresa $^{18}$, dos relatórios institucionais nele disponibilizados ${ }^{19}$ e da legislação setorial acima referida.

\section{II.4. Entrevistas}

Foram entrevistados o à época Subsecretário de Serviços Postais, Dr. Wagner Moreira dos Santos, do Ministério das Comunicações ${ }^{20}$, o advogado da Associação Brasileira das Empresas de Distribuição (ABRAED), Dr. Dauro Dórea ${ }^{21}$, e a Diretora Jurídica da Associação de Franquias Postais do Estado de São Paulo (ABRAPOST), Dra. Simone Rodrigues ${ }^{22}$.

O objetivo da realização de entrevistas foi identificar os diferentes interesses que atuam no setor postal. Tais atores vêm emergindo ao longo dos anos como grupos de interesse no setor, daí porque puderam oferecer suas impressões de pontos positivos e negativos de suas respectivas atuações no setor e dele como um todo, razão pela qual suas manifestações podem ser úteis para se fazer um estudo aprofundado do setor e de gargalos jurídicos.

As entrevistas foram utilizadas como fonte de cotejo e de reforço às ideias desenvolvidas ao longo do trabalho.

\footnotetext{
${ }^{18}$ Disponível em: <http://www.correios.com.br/>. Acesso: 22.06.2010.

${ }^{19}$ Especialmente dos relatórios "Relatório Empresarial e Social da ECT de 2008" (disponível em: $<\mathrm{http} / / / \mathrm{www}$. correios.com.br/institucional/conheca_correios/relatorios_publicacoes/relatorios_empresariais/2 008/Relatorio_ECT_2008.pdf>) e "Balanço Social dos Correios 2005" (disponível em: $<$ http://www.correios.com.br/institucional/conheca_correios/balanco_social/arquivo/balanco_social_2005[2]. pdf>). Acesso: 22.06.2010.

${ }^{20}$ Entrevista realizada no Ministério das Comunicações, junto à Subsecretaria de Serviços Postais, em 11 de fevereiro de 2011, às 14h. Acompanhou também a entrevista, fazendo algumas intervenções, a Dra. Maria Nazareth Almeida de Moraes, à época Assessora Técnica da Subsecretaria de Serviços Postais. Tempo de entrevista gravada: 1:21:04 (apresentação inicial não gravada).

${ }^{21}$ Entrevista realizada no escritório "Dauro Dórea \& Advogados", em $1^{\circ}$ de março de 2011, às 10h. O advogado falou como representante da ABRAED e tendo por base sua experiência profissional no setor. Tempo de entrevista gravada: 59:32 (apresentação inicial não gravada).

${ }^{22}$ Entrevista realizada na Associação de Franquias Postais do Estado de São Paulo, em 16 de março de 2011, às 13h. Além de Diretora Jurídica da ABRAPOST, a Dra. Simone Rodrigues é franqueada na Zona Leste de São Paulo. Tempo de entrevista gravada: 1:44:55 (apresentação inicial não gravada).
} 
Foram feitas a partir das seguintes questões-chave, sem prejuízo de no decorrer das conversas outros aspectos terem sido abordados:

a) Há notícia de algum esforço mais recente no sentido de implementar políticas públicas consistentes para o setor postal brasileiro (por exemplo, algum estudo tem sido elaborado no âmbito do Ministério)?

b) Há algum tipo de vínculo contratual entre a ECT e empresas de courier (como FEDEX, DHL etc.) e/ou qualquer autorização dada pelo Ministério ou pela ECT para a exploração de serviços postais por essas empresas privadas?

c) Qual é a concepção de cada um dos entrevistados sobre serviços postais?

d) Quantas empresas atuam no setor? Em quais áreas do país?

e) Como tem evoluído a demanda no setor?

f) Qual é o porcentual e o montante de receita que a ECT aufere das atividades monopolizadas?

g) Após a decisão do STF na ADPF n. ${ }^{\circ}$ 46-7/DF, tem-se conhecimento da implantação e/ou reforço de ações para eliminar a exploração por empresas privadas de serviços postais monopolizados pela ECT?

h) Quais são os serviços prestados pelas empresas privadas? 


\section{CAPÍTULO 1 - REALIDADE DO SETOR POSTAL NO BRASIL}

\section{III.1. Considerações históricas: um breve panorama dos serviços postais}

\section{III.1.1. Transformação do DCT na ECT}

Historicamente no Brasil os serviços postais são prestados diretamente pelo Estado, primeiro pela Administração Direta e depois pela Indireta, através do mecanismo da descentralização. Em 1931 foi criado o Departamento de Correios e Telégrafos (DCT), subordinado ao Ministério da Viação e Obras Públicas e, a partir de 1968, ao Ministério das Comunicações. Posteriormente, o Estado passou a prestar os serviços através da Empresa Brasileira de Correios e Telégrafos ("ECT"; popularmente conhecida pela marca “Correios”), empresa pública nascida a partir da transformação do DCT.

Havia na época um forte estímulo para que atividades estatais até então alocadas na Administração Direta passassem a ser desempenhadas sob outros modelos jurídicos, criados pelo processo de descentralização administrativa. Partia-se da ideia de que era preciso capacitar os entes da Administração de maior autonomia gerencial e financeira, e de flexibilidade de ação, o que não os impediria de desempenhar atribuições de natureza pública $^{23}$. Esses novos modelos jurídicos tiveram grande proliferação nas décadas de 1940 a 1960, especialmente em razão da exploração estatal de indústrias de base e do declínio das concessões de serviços públicos. O aumento foi tão acentuado que no ano de 1963 a Administração Direta Federal representava no Brasil um terço das atividades exercidas sob a égide do $\mathrm{Estado}^{24}$.

\footnotetext{
${ }^{23}$ A esse respeito, ver Manuel de Oliveira Franco Sobrinho, "Regime jurídico das empresas públicas no Brasil", Revista de Direito Público, v. 12, p. 18-19.

${ }^{24}$ Cf. Caio Tácito, “As empresas públicas no Brasil”, Revista de Direito Administrativo, v. 84, p. 433.
} 
Além da ECT (1969), data desse período a criação de importantes empresas, como a Companhia Siderúrgica Nacional (1941), a Companhia Vale do Rio Doce (1942), a Companhia Hidrelétrica do São Francisco (1945), a Petrobras (1953), a Rede Ferroviária Federal (1957) e a Eletrobrás - Centrais Elétricas Brasileiras (1961). A expansão de novas estruturas integrantes da máquina administrativa foi tão significativa no período que, especificamente em 25 de fevereiro de 1967, foi editado o decreto-lei n. ${ }^{\circ}$ 200, consolidando do ponto de vista jurídico essas novas entidades integrantes da chamada Administração Indireta (autarquias, empresas estatais ${ }^{25}$ e fundações públicas).

Nesse contexto, a passagem do DCT para a ECT costuma ser lembrada como um momento importante de renovação da prestação dos serviços postais ${ }^{26}$. Os serviços prestados pelo DCT eram considerados de baixa qualidade (com problemas de cumprimento de prazos das entregas, por exemplo) e a gestão dos serviços era considerada pouco eficiente (o serviço era deficitário e a gestão do departamento era marcada por fortes injunções políticas). O decreto-lei n. ${ }^{\circ}$ 509, de 20 de março de 1969, foi o responsável por essa transformação, tendo conferido à ECT a exploração de diversas atividades em regime de "monopólio"27, cujo alcance foi posteriormente delimitado pela lei n. ${ }^{\circ}$ 6.538/78.

\section{III.1.2. Realidade atual da prestação do serviço postal no Brasil}

Desde este momento inicial de criação da ECT, o setor postal vem passando por diversas transformações, que se voltam de maneira significativa à ampliação dos serviços postais e à proliferação de prestadores no setor. A realidade do setor postal é, por assim dizer, marcada por uma significativa ampliação das atividades prestadas dentro do que se denomina "serviço postal", e pelo surgimento e ampliação de diversos prestadores, que vão muito além da ECT, embora ela continue sendo um grande referencial do mercado postal.

\footnotetext{
${ }^{25}$ A denominação "empresas estatais" engloba as empresas públicas, as sociedades de economia mista e as empresas em que o Estado detenha controle, direta ou indiretamente.

${ }^{26}$ Cf. Exposição de motivos EMI n. ${ }^{\text {89/MC/MF/MOG do PL n. }}{ }^{0} 1.491 / 99$, p. 6.

${ }^{27}$ Ao longo deste trabalho, quando a referência à exclusividade na prestação dos serviços postais for feita como "monopólio", serão utilizadas aspas, embora essa terminologia seja utilizada pela legislação postal, conforme justificativa apresentada no item V.3.1.
} 


\section{III.1.2.1. Ampliação dos serviços postais}

Em 1969, quando o DCT foi transformado na ECT, o núcleo material das atividades postais era bastante restrito, quando comparado à proporção que os serviços adquiriram com o passar do tempo. Natural que assim seja. Nas últimas décadas assistiu-se a uma grande mudança nas comunicações, não só no Brasil, como também no cenário internacional. Os avanços tecnológicos permitiram a criação de diversos mecanismos que possibilitam a comunicação entre as pessoas, que vão muito além da carta, um tradicional meio de comunicação. Hoje a sociedade se relaciona também e em grande medida através da internet e da telefonia, marcadas por suas diversas modalidades (webcam, e-mail, telefonia fixa, móvel, dentre tantas outras).

Essa alteração no cenário nacional e internacional das comunicações tem impactado de maneira significativa as características do setor postal brasileiro. O processo de adaptação pelo qual o setor tem passado influencia a forma de prestação dos serviços, o volume de depósitos (faturamento) ${ }^{28}$ do setor, o padrão de consumo, o perfil dos usuários etc., e exige do setor uma conformação expressiva no que tange às atividades exploradas pelas prestadoras do setor postal. Isso porque a perda de importância dos serviços que constituíram no passado o cerne da atividade postal (como carta, cartão-postal, telegrama) tem levado as prestadoras do setor a travarem uma grande luta pela sua sobrevivência.

Por conta da proporção que os serviços vêm assumindo nos últimos anos, seja em razão da criação de novos serviços, seja em razão de toda a segmentação da rede para atender a diversos clientes (os que querem fazer compras pela internet, os que querem que uma encomenda seja entregue mais rápido etc.), é possível afirmar-se que atualmente existe uma verdadeira "rede postal", que engloba um leque bastante abrangente de produtos e serviços, alguns propriamente postais (os serviços mais tradicionais) e alguns ancilares (agregados aos serviços postais tradicionais, mas que utilizam a rede do setor).

\footnotetext{
${ }^{28} \mathrm{Na}$ linguagem técnica utilizada no setor financeiro, é apropriado o uso dos termos "volume de depósitos" e "montante de transações" para referir-se à ideia de "faturamento", termo muito mais comum na linguagem cotidiana. Na presente pesquisa, optou-se por fazer referência às duas expressões.
} 
Desse alargamento dos serviços postais, propiciado por aspectos mais econômicos do que jurídicos, de como manter a sobrevivência do setor (aonde serão investidos recursos, quais são as atividades lucrativas e deficitárias, quais nichos de mercado estão surgindo etc.), claramente derivam efeitos jurídicos, eis que o regime jurídico de determinado setor da economia é concebido considerando o núcleo material dos serviços que engloba. Disso advém a importância de saber o que é hoje prestado dentro do que se denomina "serviço postal", e justifica a existência de um capítulo específico para tratar do conteúdo dos serviços postais (Capítulo 2).

\section{III.1.2.2. Proliferação de prestadores no setor}

A transformação por que tem passado o setor postal não se restringe à criação de uma rede postal com uma variada gama de produtos e serviços e à mudança da indústria que a essa criação se relaciona. Ao longo do tempo tem-se assistido também a uma grande proliferação dos agentes econômicos prestadores dos serviços postais.

É certo que foge ao escopo do presente trabalho tratar profundamente de cada uma das formas de prestação dos serviços postais (o tema das franquias, por exemplo, por si só pode ser objeto de uma dissertação), mas, sem a pretensão de exaurir o tema, é importante que se faça referência aos principais atores do setor postal e o que nele representam, a fim de que se tenha um conhecimento mais amplo do setor e se possa avaliar, por exemplo, seus principais problemas e desafios.

Em 1969, quando o DCT foi transformado na ECT, ela era talvez o único operador dos serviços postais no Brasil. Ainda hoje ela é o único operador público (empresa estatal), prestando os serviços postais diretamente através das agências de correio próprias. No entanto, especialmente a partir da década de 1990, esse operador público passou a coexistir com diversas outras empresas privadas.

Com algumas estabeleceu um vínculo contratual, uma parceria de propagação da rede pública "Correios", daí o nascimento das agências de correio franqueadas e, posteriormente, das agências de correio permissionárias. De maneira assemelhada, para garantir a expansão de sua rede de atendimento, especialmente para as comunidades mais carentes, estabeleceu parcerias, substancialmente com os órgãos governamentais, daí o surgimento das agências de correio comunitárias. Por outro lado, passou a conviver competitivamente com outras empresas, sem qualquer vínculo de outorga ou parceria, em 
razão da proliferação das chamadas empresas de distribuição, também denominadas courier.

A tabela abaixo apresenta a quantidade de prestadores por tipo de agência:

\begin{tabular}{|l|c|}
\hline \multicolumn{1}{|c|}{ Tipo } & Quantidade $^{29}$ \\
\hline Agência de Correio & 6.307 \\
\hline Agência de Correio Filatélica & 30 \\
\hline Agência Comercial Tipo 1 (Permissionária) & 228 \\
\hline Agência de Correio Franqueada & 1.390 \\
\hline Agência de Correio Comunitária & 4.207 \\
\hline Caixas de Coletas & 12.162 \\
\hline Empresas privadas de distribuição & 15.000 \\
\hline
\end{tabular}

Através das agências próprias, hoje mais de 6.000, a ECT presta diretamente os serviços postais, desde 1969.

Em 1989 a empresa adotou o sistema de franchising, instituto nascido e desenvolvido tipicamente no setor privado, para a delegação à iniciativa privada da operação de agências postais, imaginado como uma medida para se injetar recursos privados na preservação e ampliação da rede de atendimento da estatal, sem os custos que envolveria a criação de novas agências para a Administração Pública.

${ }^{29}$ Fonte: dados oficiais obtidos no site da ECT. Disponível em: <http://www.correios.com.br/sobreCorreios/empresa/quemSomos/principaisNumeros.cfm>. Acesso: 21.07.2011. O único dado que não consta do site da estatal é o de empresas de distribuição, que foi obtido na petição inicial da ADPF n. ${ }^{\circ}$ 46-7/DF, p. 6. 
Conforme informações coletadas junto à ABRAPOST-SP ${ }^{30}$, de 1989 a 1994 foram firmados contratos de franquia para a operação de 1.737 Agências de Correio Franqueadas (ACF’s) no território brasileiro. A Administração Pública adotou o sistema de franquias independentemente de lei que tratasse do assunto ou mesmo de lei específica para o setor, observando-se a legislação em geral ${ }^{31}$, e existente alguma liberdade para os ajustes serem moldados de acordo com os casos concretos.

Segundo Maria Sylvia Zanella Di Pietro, o contrato de franquia assemelha-se em grande medida ao contrato de concessão tradicional de serviço público, com a diferença de que a atuação e organização do franqueado sofre limitações muito maiores do que o concessionário $^{32}$, pois o franqueado tem menor liberdade para a execução de suas atividades. $\mathrm{O}$ franqueado não atua em nome próprio segundo suas técnicas de organização e trabalho, mas assume o nome do franqueador, e presta os serviços de acordo com técnicas de atuação que ele determina, sujeitando-se ao pagamento de uma remuneração.

Aproximando as franquias das concessões de serviços públicos, Maria Sylvia Zanella Di Pietro apresenta os seguintes contornos das franquias ${ }^{33}$ : por meio delas transferem-se ao franqueado poderes e deveres próprios do franqueador, que conserva, no entanto, alguns poderes e deveres, como o de controlar e fiscalizar a atuação do franqueado, dar-lhe treinamento e assistência necessários à execução do serviço, e fornecer-lhe os bens necessários para tanto.

Especificamente no caso das franquias postais, a modelagem inicial dos contratos, segundo matéria publicada no jornal O Estado de São Paulo, autorizava as franquias a atuar no varejo (venda de produtos ou comercialização de serviços em pequenas quantidades), mas ao longo do tempo mudaram de perfil, passando a concentrar suas atividades no atacado, com a distribuição de correspondência de bancos, companhias seguradoras, redes de supermercado e empresas especializadas em mala direta ${ }^{34}$. Com isso, segundo a matéria, o volume de depósitos (faturamento) das franquias cresceu muito (entre

\footnotetext{
${ }^{30}$ Informações oriundas da entrevista e de documento interno enviado pela ABRAPOST-SP, "Histórico ACF e análise do edital 2009".

${ }^{31}$ Segundo Maria Sylvia Zanella Di Pietro, se a franquia for feita como concessão de serviço público, deve ser-lhe aplicada a lei n. $^{\circ} 8.987 / 95$. No caso de ser feita nos moldes de serviço, ser-lhe-á aplicável a lei n. ${ }^{\circ}$ 8.666/93, conforme art. 62, $\S 3^{\circ}$, I. Cf. Parcerias na administração pública, p. 206 e 210.

${ }^{32}$ Maria Sylvia Zanella Di Pietro, Parcerias na administração pública, p. 210.

${ }^{33}$ Maria Sylvia Zanella Di Pietro, Parcerias na administração pública, p. 210. Sobre as notas características do instituto das franquias, ver também Dinorá Adelaide Musetti Grotti, $O$ serviço público e a Constituição Brasileira de 1988, p. 214 a 220.

${ }^{34}$ Cf. notícia "Monopólio postal".
} 
1998 e 2002 as agências tiveram um faturamento de mais de US\$ 1 bilhão), e as agências passaram a ser cobiçadas por partidos políticos. Ainda segundo a matéria, com o tempo a ECT perdeu o controle dos franqueados, pois vários deles teriam revendido o negócio ou passado a atuar por meio de "laranjas".

A partir de 1994 passou-se a questionar a delegação dos serviços postais através dessa forma de contratação, especialmente em razão da falta de licitação, o que em certa medida afasta as franquias postais das concessões e permissões de serviço público, formas de delegação que regra geral são precedidas de licitação. O Tribunal de Contas da União, por meio da decisão 601/94 - Plenário (de 21/09/1994) determinou que a ECT passasse a observar o procedimento licitatório para a concessão de novas franquias. As já existentes tiveram uma sobrevida garantida pela decisão do TCU 721/94 - Plenário (de 30/11/1994) que excetuou de sua determinação anterior as agências franqueadas já existentes e as que estavam na fase de concretização dos contratos ${ }^{35}$.

Em decorrência das determinações do TCU, segundo a ABRAPOST-SP ${ }^{36}$, a partir de 1994 a ECT não celebrou mais nenhum novo contrato de franquia, nos moldes então existentes. E dessa rede inicial, segundo a ABRAPOST-SP ${ }^{37}$ hoje existem 1.429 ACF's (os dados oficiais do governo se referem a 1.390, conforme tabela reproduzida acima), quantidade que ainda é representativa no setor. Uma série de instrumentos normativos foi a partir de então elaborada, a fim de postergar o término das contratações realizadas pela ECT sem licitação. A lei n. ${ }^{\circ} 9.648 / 98$ introduziu um parágrafo único no art. $1^{\circ}$ da lei n. ${ }^{\circ}$ 9.074/95, tendo estabelecido que as franquias celebradas poderiam permanecer em vigor até o limite máximo de 31 de dezembro de 2002. Perto do fim do prazo foi editada a lei n. ${ }^{\circ}$ 10.577, de 27 de novembro de 2002, que conferiu às franquias outorgadas o prazo de mais cinco anos, a partir da publicação da lei.

Próximo ao término do prazo de cinco anos foi editada a medida provisória n.$^{\circ} 403$, de 26 de novembro de 2007. Por meio dela foram conferidos contornos jurídicos às novas franquias postais, mas mais uma vez houve uma preocupação em garantir-se a sobrevida às contratações anteriormente firmadas. A MP estabeleceu que até que entrassem em vigor os (novos) contratos de franquia postal, celebrados de acordo com suas novas previsões, continuariam com eficácia os firmados com as ACF's que estivessem em vigor em 27 de

\footnotetext{
${ }^{35}$ Cf. petição inicial da ADI n. ${ }^{\circ}$ 4155, em tramitação no Supremo Tribunal Federal.

${ }^{36}$ Informações obtidas junto à ABRAPOST-SP.

${ }^{37}$ Informações obtidas junto à ABRAPOST-SP.
} 
novembro de 2007 (art. $7^{\circ}$, caput). Conferiu-se um prazo máximo de dezoito meses, a contar de 28 de novembro de 2007, para que fossem concluídas todas as contratações anteriores firmadas com as franqueadas (art. $7^{\circ}$, parágrafo único).

Esta medida provisória foi convertida na lei n. ${ }^{\circ} 11.668$, de 02 de maio de 2008, com algumas alterações. A lei prorrogou o prazo de dezoito meses anteriormente previsto para vinte e quatro meses, contado a partir da data da publicação da regulamentação da lei, a ser editada pelo Poder Executivo (art. $7^{\circ}$, parágrafo único; neste sentido, o art. 10 revogou o $\S 1^{\circ}$ da lei n. $\left.{ }^{\circ} 9.074 / 95\right)$.

Em 07 de novembro de 2008 foi editado o decreto $n .^{\circ}$ 6.639, regulamentando a lei que trata do exercício da atividade de franquia postal. Cerca de seis meses depois, em 12 de junho de 2009, o ministro Gilmar Mendes, em decisão monocrática (Suspensão de Tutela Antecipada n. ${ }^{\circ}$ 335/DF), deferiu pedido de tutela antecipada formulado pela União, sustando os efeitos do acórdão proferido pelo Tribunal Regional Federal que havia determinado que a ECT promovesse, no prazo de cento e oitenta dias, a substituição de todos os contratos de franquia celebrados sem prévia licitação. Os efeitos desse acórdão foram suspensos pelo ministro Gilmar Mendes até o dia 10 de novembro de 2010 (vinte e quatro meses a partir da edição do decreto, prazo que fora fixado na lei n. ${ }^{\circ} 11.668 / 08$ ) ou até a decisão final do processo principal, se este ocorresse antes da decisão fixada.

O ministro justificou sua decisão nas seguintes razões: (i) a razoabilidade do prazo atualmente existente, em razão da complexidade inerente à realização do procedimento licitatório e à extinção de ajustes que vigoram há quase vinte anos; (ii) a falta de demonstração pelo juiz prolator da decisão impugnada de que o prazo de cento e oitenta dias atenderia melhor ao interesse público ou às exigências constitucionais, do que o prazo definido em lei; (iii) a comprovação pela ECT de que parte considerável dos serviços postais é hoje desempenhada pelas agências franqueadas (cerca de 25\% nas áreas de maior concentração populacional) e que o procedimento licitatório ainda não havia sido concluído; e (iv) o prazo estipulado pela decisão judicial colocava em risco a adequada prestação dos serviços. O ministro ressaltou, no entanto, a necessidade de o Ministério das Comunicações e a ECT observarem os prazos estipulados na lei n. $.^{\circ} 11.668 / 08$, “....sob pena de perpetuação de um quadro de patente inconstitucionalidade".

Conforme notícia publicada no jornal Folha de São Paulo no dia seguinte à decisão do STF, diante da liminar (cassada pelo STF), do descumprimento dos prazos pelos Correios e da importância atual das franquias para a prestação do serviço postal, 
“...começaram a surgir especulações de que o país estava à beira de um 'apagão postal ${ }^{, 38}$.

Porém, mais uma vez o quadro se perpetuou com a edição da medida provisória . $^{\circ}$ 509, de 13 de outubro de 2010, que novamente alterou a redação do art. $7^{\circ}$, parágrafo único da lei n. ${ }^{\circ}$ 11.668/08, passando a prever que a ECT deveria concluir as contratações das antigas ACF's até 11 de junho de 2011. Com a prorrogação do prazo final previsto para as atividades das franqueadas, mais uma vez garantiu-se sobrevida aos antigos contratos de franquia outorgados sem licitação.

Conforme notícia do jornal Folha de São Paulo ${ }^{39}$, a um mês do final do prazo, existiam apenas 277 franquias com o processo licitatório concluído e contratos assinados (o processo licitatório de 504 agências estava em andamento e o de 519 estava paralisado, pois as agências haviam conseguido liminares na justiça suspendendo as licitações). Segundo a notícia, isso fez com que o governo cogitasse colocar em prática um plano emergencial para contratar trabalhadores temporários e alugar imóveis e veículos. Dado o custo que isso representaria (cerca de $\mathrm{R} \$ 550$ milhões, conforme a matéria) e em razão de questões políticas (relacionadas, por exemplo, a reivindicações para que os editais de licitação fossem alterados em alguns pontos), optou-se por abortar o plano e mais uma vez prorrogar os prazos dos contratos, dessa vez por sete meses (de 10 de novembro de 2010 a 11 de junho de 2011).

Em 7 de abril de 2011 foi editada a lei n. ${ }^{\circ}$ 12.400, que mais uma vez alterou o prazo de vigência das antigas contratações, desta vez prorrogando-o até 30 de setembro de 2012 (nova redação do art. $7^{\circ}$, parágrafo único da lei n. ${ }^{\circ} 11.668 / 08$ ). Conferiu ainda às novas ACF's prazo de doze meses para fazerem as adequações e padronizações definidas pelas normas técnicas e manuais da ECT.

Os novos contratos de franquia (Correios Conveniência) são disciplinados pela lei n. ${ }^{\circ} 11.668 / 08$ e pelo decreto n. $^{\circ}$ 6.639/08, um modelo diferente do que estava sendo operado $^{40}$. Além de as outorgas serem feitas mediante procedimento licitatório, esse

\footnotetext{
${ }^{38}$ Cf. notícia "STF amplia prazo para franquias dos Correios".

${ }^{39}$ Notícia "Governo muda Correios para evitar 'apagão"”. Ver também "Contratos de franquias dos Correios são prorrogados por sete meses".

${ }^{40}$ Veja a esse respeito a previsão constante do documento Perguntas e Respostas aos franqueados dos Correios: “1.2. Por que os operadores de unidade dos Correios não podem operar ao mesmo tempo a unidade que possuem e a Correios Conveniência? Faz parte da estratégia de terceirização de Agências da ECT não permitir que seus parceiros terceirizados operem diferentes tipos de unidade de atendimento, ao mesmo tempo. Entretanto, caso seja do interesse dos parceiros, poderão participar de licitação para operar
} 
modelo tem prazo de vigência de dez anos (havendo possibilidade de uma prorrogação) e objeto limitado ao desempenho de "atividades auxiliares relativas ao serviço postal" (art. $1^{\mathrm{o}}, \S 1^{\mathrm{o}}$ da lei).

Segundo entrevista junto à ABRAPOST-SP ${ }^{41}$, os franqueados não são contrários à adequação do modelo de franquias postais, nem são contra a celebração de novos contratos de franquia precedidos de licitação. Entendem, no entanto, que o modelo proposto pela ECT/Ministério das Comunicações, consubstanciado no edital de licitação e contrato que dele é parte integrante, é temerário, inviabilizando o modelo de franquias, razão pela qual têm reivindicado que, corrigidos os equívocos que eles veem no edital, ele seja republicado e reiniciado o processo licitatório.

Neste sentido seria um equívoco a licitação não levar em consideração, como critério de pontuação diferenciado ou de desempate, a experiência do franqueado que operou durante todos esses $\operatorname{anos}^{42}$, e haveria problemas em relação ao método de remuneração dos franqueadas no novo modelo ${ }^{43}$. Neste cenário, há notícia de que a ECT promoveria audiência pública com o objetivo de discutir o modelo de edital para as futuras $\mathrm{ACF}^{\prime}{ }^{44}$, o que ocorreu no dia 25 de julho de $2011^{45}$.

um modelo diferente do que já operam, adotando as providências para a migração para o modelo que estão pretendendo". Disponível em: <http://www.correios.com.br/servicos/licita_agencias/faq_franqueado.cfm>. Acesso: 25.06.2010.

41 A atual rede franqueada que ainda opera as antigas franquias postais se organizou em associações (estaduais, como a ABRAPOST-SP, que formam uma única rede nacional, a ABRAPOST nacional).

42 Segundo entendem, o edital teria deixado de prever critérios técnicos, de considerar os postos de atendimento existentes e o tempo em que estão instalados no local e de exigir a comprovação de pessoal especializado, e expertise para atendimento, manuseamento e tratamento do material. Por outro lado, por ser único, o edital teria previsto os mesmos critérios prediais para o país inteiro, deixando de considerar, por exemplo, as condições topográficas das diferentes regiões, e apresentaria o equívoco da desproporcionalidade entre as infrações e as sanções que lhes são correlatas.

${ }^{43} \mathrm{O}$ método atual de remuneração dessas antigas agências franqueadas é inversamente proporcional ao seu volume de depósitos (faturamento), enquanto que o novo limitaria a remuneração a um teto. Paralelamente, nos novos contratos haveria proibições para a exploração de serviços como o de marketing direto.

44 Disponível em: <http://www.correios.com.br/fornecedores/licitacaoagf/default.cfm> e $<$ http://www.abrapostsp.org.br/home/>. Acesso: 21.07.2011.

45 "Correios busca melhoria na parceria com franqueados". Disponível em: <http://blog.correios.com.br/correios/2011/07/27/correios-busca-melhoria-na-parceria-com-franqueados/>. Acesso: 19.12.2011. 
Diante disso, fato é que hoje, a despeito de todos os questionamentos e das prorrogações para a regularização do uso das franquias pela Administração Pública no setor postal, elas ainda continuam sendo importantes prestadores de serviços no setor, ofertando cerca de $25 \%$ dos serviços postais nas áreas de maior concentração populacional $^{46}$.

Semelhante ao modelo de franquia, mas precedido de procedimento licitatório e com diferenças contratuais (relacionadas, por exemplo, ao valor do volume de depósitos faturamento - e à abrangência dos serviços que podem ser operados), a ECT também propaga sua rede de atendimento através das 228 agências de correio permissionárias atualmente existentes.

Em 2001 a portaria n. 386 autorizou a ECT a realizar procedimentos licitatórios em todo o país, para selecionar pessoas jurídicas interessadas em prestar serviços e vender produtos postais, por meio do instituto da permissão, em unidades de atendimento que foram denominadas Agências de Correio Comerciais (ACC's) do Tipo I. Os critérios e a disciplina dos procedimentos para a seleção de interessados em celebrar contratos de permissão foram posteriormente delineados pela portaria $n .^{\circ} 01 / 01$ e demais normas infralegais.

Também operam no setor mais de 4.000 Agências de Correio Comunitárias, cujo procedimento de implantação está disciplinado na instrução normativa $n{ }^{\circ}{ }^{\circ}$, de 14 de dezembro de 2000. São definidas como unidades de atendimento que buscam viabilizar, no mínimo, a prestação de serviços postais básicos ${ }^{47}$, “...em pequenas localidades com população superior a quinhentos habitantes, bem como em áreas urbanas onde predomine o interesse social e a exploração econômica de serviços postais não se mostre viável".

\footnotetext{
${ }^{46}$ Cf. decisão monocrática do ministro Gilmar Mendes. STA 335/DF. Suspensão de Tutela Antecipada. Relator: Ministro Presidente Gilmar Mendes. Julgamento: 12/06/2009.

${ }^{47}$ São considerados básicos os serviços referidos na portaria n. ${ }^{\circ} 310 / 98$, art. $5^{\circ}$ : entrega interna de objetos; cheque Correios e produtos congêneres; cartas simples e registradas, sem valor declarado; encomendas não urgentes, sem valor declarado; e telegrama.
} 
Trata-se de agências terceirizadas, operadas mediante a celebração de convênios, acordos, ajustes ou outros instrumentos congêneres (lei n. ${ }^{\circ} 8.666 / 93$, art. 116 e lei n. ${ }^{\circ}$ $6.538 / 78$, art. $2^{\circ}, \S 3^{\circ}$ ), por entidades públicas ou privadas, conforme procedimento específico de seleção das entidades que têm condições de operá-las. Na prática, conforme entrevista realizada no Ministério das Comunicações, em geral essas agências que têm caráter mais "social", incapazes de gerar lucro, operam por intermédio de convênios com Estados, Municípios, associações comunitárias e de moradores.

De acordo com a instrução normativa que disciplina a parceria, para seu funcionamento o instrumento de contratação especifica a transferência de recursos pela ECT, quando necessária, e a contrapartida do operador terceirizado. Pode-se estabelecer, por exemplo, que a Prefeitura ceda uma sala ou um funcionário, e o Correio providencie mobiliário e treinamento, garantindo a remuneração acordada ${ }^{48}$.

Na década de 1990 o setor também assistiu a uma proliferação bastante expressiva de empresas privadas de distribuição (courier). Como não há mecanismos de controle de acesso desses operadores, não se tem a dimensão exata de quantas empresas privadas atuam no setor, nem do modo como estão distribuídas pelo país ${ }^{49}$. No final de 2003 , quando foi impetrada pela Associação Brasileira das Empresas de Distribuição (ABRAED) no STF a ADPF n. ${ }^{\circ}$ 46-7/DF, a associação mencionava que atuavam no setor cerca de 15.000 empresas privadas de distribuição de serviços postais ${ }^{50}$, pelo país inteiro.

Esse número (que atualizado deve ser ainda maior), no entanto, representa apenas empresas nacionais de pequeno e médio porte (com no máximo 3.000, 4.000 empregados), que são as empresas representadas pela associação ${ }^{51}$, não englobando empresas multinacionais de grande repercussão, como FEDEX, UPS, DHL, TNT, GNT ${ }^{52}$, nem grandes nacionais como TAM CARGO, VARIG LOG ${ }^{53}$, dentre outras, nem, obviamente, a concorrência informal.

\footnotetext{
${ }^{48}$ Informação obtida junto ao Ministério das Comunicações.

${ }^{49}$ Informação obtida junto ao Ministério das Comunicações.

${ }^{50}$ Cf. petição inicial da ADPF n. ${ }^{\circ}$ 46-7/DF, p. 6.

${ }^{51}$ Informação obtida junto à ABRAED.

52 FedEx Express Brasil: <http://fedex.com/br/>. UPS Tracking: $<$ http://www.ups.com/content/br/pt/shipping/index.html?WT.mc_id=TMP_Brazil_11891\&WT.srch=1>. DHL Express: <http://www.dhl.com.br/pt.html>. TNT Txpress: <http://www.tnt.com/express/pt_br/site/home.html>. GNT Express: <http://www.gntexpress.com.br/>. Acesso: 21.04.2011.

53 Tam Cargo: <http://www.tamexpress.com.br/ste/jsp/default.jhtml?adPagina=458>. Varig Log: $<$ http://www.variglog.com/velog-economico.html>. Acesso: 21.04.2011.
} 
Assim, pode-se afirmar que a participação dessas empresas privadas atualmente no mercado postal é bastante expressiva, e da casa de milhares. No segmento internacional a participação é mais concentrada, atuando basicamente essas grandes empresas multinacionais. No segmento nacional a participação é mais pulverizada, atuando desde pequenas empresas até grandes operadoras ${ }^{54}$.

Todas essas empresas privadas vivem numa realidade de livre mercado, inexistindo qualquer vínculo com o Ministério das Comunicações ou com a ECT, nem mecanismos de controle de acesso, preços ou financiamento ${ }^{55}$. Basta à prestadora constituir-se como empresa e, como sociedade comercial autorizada a funcionar (com Cadastro Nacional de Pessoa Jurídica - CNPJ etc.), regular-se pelas leis comerciais e civis do país.

Atualmente, portanto, coexistem no setor postal diferentes agentes econômicos prestadores dos serviços, que ao longo do tempo assumiram um papel importante no setor, submetidos, no entanto, a regimes jurídicos bastante distintos entre si. Traçado esse panorama em torno da realidade atual da prestação do serviço postal no Brasil, analisar-seá em seguida o que o setor postal representa no cenário atual das comunicações brasileiras.

\section{III.2. Setor postal no cenário atual das comunicações}

\section{III.2.1. Déficit de regulação do setor postal: políticas públicas setoriais versus políticas da ECT e déficit de planejamento para o setor}

No final da década de 1990, em meio a um processo de reformulação de diversos setores de infraestrutura brasileiros, foi elaborado e discutido um projeto de lei que previa uma reestruturação no setor postal (projeto de lei n. ${ }^{\circ}$ 1.491/99). O projeto, que intencionava implantar um desenho regulatório diferente do que se tem hoje e teve à época ampla repercussão, foi abortado em 2003 e desde então o debate sobre o setor é praticamente inexistente ${ }^{56}$, mesmo no cenário político.

\footnotetext{
${ }^{54}$ Informação obtida junto ao Ministério das Comunicações.

${ }^{55}$ Informação obtida junto ao Ministério das Comunicações.

${ }^{56}$ Outro projeto que tramitou no Legislativo, do qual temos conhecimento, é o PL n. ${ }^{\text {o } 3.677 / 2008 . ~ T r a t a-s e ~ d e ~}$ projeto que teve menor repercussão e que propunha alterar a lei n. ${ }^{\circ} 6.538 / 78$, excluindo do regime de monopólio da União o transporte e a entrega de carta e cartão-postal para localidades ou horários não atendidos pela ECT e quando executados para endereços não fixos.
} 
Após, entre os anos 2009 e 2010, conforme informações obtidas junto ao Ministério das Comunicações, foi criado um grupo de trabalho, denominado "Grupo de Trabalho Interministerial" (GTI) ${ }^{57}$, do qual participaram representantes da Casa Civil da Presidência da República, do Ministério da Fazenda, do Ministério do Planejamento, Orçamento e Gestão, do Ministério das Comunicações e da ECT. O objetivo do grupo foi o de elaborar propostas que poderiam servir de suporte para uma possível e futura tomada de decisão política. As discussões do grupo e consequentemente as propostas por ele elaboradas (o relatório não tem acesso público), no entanto, voltaram-se especificamente à ECT, de maneira que o objetivo desse grupo foi o de dar respostas de curto e médio prazo para aprimorar a gestão da ECT enquanto empresa estatal.

Nesse contexto, no início do ano de 2010, conforme notícias publicadas, o exministro das comunicações, Hélio Costa ${ }^{58}$, apresentou ao ex-presidente Luiz Inácio Lula da Silva uma minuta de medida provisória para (i) promover a modernização e flexibilização das operações dos Correios, que permitiria (i.1) a utilização de sua infraestrutura para comercialização de produtos como seguros e chips para telefones celulares, e (i.2) a operação da estatal no exterior, com a abertura de agências em outros países, e (ii) para transformar os Correios, de empresa pública de direito privado numa sociedade anônima de capital fechado, a Correios do Brasil S/A. A reformulação da estatal seria necessária para a recuperação de clientes e aumento da receita porque, segundo o então ministro, “...senão estaremos fadados em dois anos a ser uma carga pesada para o governo"59.

Posteriormente, fruto direto das discussões e propostas apresentadas pelo $\mathrm{GTI}^{60} \mathrm{e}$ dessa minuta de medida provisória, em 28 de abril de 2011, foi editada a medida provisória n. ${ }^{\circ}$ 532, convertida (com algumas alterações) na lei n. ${ }^{\circ}$ 12.490, de 16 de setembro de 2011, que ao mesmo tempo em que aprovou um pacote de medidas relativas a combustíveis,

\footnotetext{
${ }^{57}$ Informação obtida em entrevista no Ministério das Comunicações. Coube ao entrevistado, Wagner Moreira dos Santos, então Subsecretário de Serviços Postais, presidir esse grupo de trabalho.

${ }^{58}$ Hélio Costa foi ministro das comunicações de julho de 2005 a março de 2010 . Atualmente, desde $1^{\circ}$ de janeiro de 2011, o cargo é ocupado pelo ministro Paulo Bernardo Silva. Disponível em: <http://www.mc.gov.br/o-ministerio/o-ministro>. Acesso: 16.01.2011.

59 Cf. notícia "Modernização dos correios prevê agências no exterior". Ver também notícia "Um novo correio?".

${ }^{60}$ A exposição de motivos que acompanha a MP 532 é clara nesse sentido: "7. Em relação à modernização da ECT, a referida Medida Provisória se fundamenta nas recomendações apresentadas pelo Grupo de Trabalho Interministerial - GTI, instituído por meio do Decreto $s / n .^{\circ}$ de 22 de outubro de 2008, publicado no Diário Oficial da União - DOU, n. ${ }^{\circ}$ 206, de 23 de outubro de 2008, Seção 1, pg. 9, com a finalidade de elaborar estudos e propor diretrizes para a modernização da ECT." (EM INTERMINISTERIAL n. ${ }^{\circ}$ 00013/MME/MF/MDIC/MAPA/MC/MP, de 28 de abril de 2011). Disponível em: <http://www.planalto.gov.br/ccivil_03/_Ato2011-2014/2011/Exm/EMI-13-MME-MF-MDIC-MAPA-MCMP-Mpv532.htm>. Acesso: 13.07.2011.
} 
alterou o decreto-lei n. ${ }^{\circ}$ 509/69, que criou a ECT. Todas as ações adotadas para o setor postal pela MP relacionam-se à ECT, especificamente à gestão da estatal, e, de maneira geral, colocam em prática as medidas já pensadas no governo anterior, em 2010.

O "pacote" de medidas aprovadas volta-se claramente à gestão da estatal, o que denota uma preocupação governamental, ao menos imediata, mais focada no seu aprimoramento, ficando em plano secundário a avaliação do quadro maior do setor postal brasileiro. A este respeito, a exposição de motivos da MP é bastante clara sobre a necessidade de modernização da estatal. A partir da constatação de que hoje o ambiente no qual a ECT atua é muito mais dinâmico, por conta da globalização econômica e integração de mercados e da disseminação da comunicação eletrônica, e do entendimento segundo o qual os serviços postais continuam sendo vitais, entendeu-se necessário enfrentar as limitações de gestão da estatal que estariam a impedir a empresa de se desenvolver.

Diante disso, tendo por base o conjunto de propostas de diretrizes para a modernização da ECT elaborado pelo GTI a partir da análise da situação atual da ECT e com foco nos problemas identificados, a lei n. ${ }^{\circ} 12.490$ parte de duas frentes, quais sejam, criar um ambiente mais propício à ampliação do âmbito de atuação da ECT e aperfeiçoar os mecanismos de governança da estatal.

Neste sentido, de um lado a empresa teve sua atuação ampliada, de modo a também poder desenvolver suas atividades no exterior (nova redação do decreto-lei n. ${ }^{\circ} 509$, art. $1^{\circ}$, $\left.\S 2^{\circ}\right)$ e, para que possa executar as atividades compreendidas em seu objeto, foi expressamente conferida à estatal a possibilidade de constituir subsidiárias e adquirir o controle ou participação acionária em sociedades empresárias já estabelecidas (incisos I e II do $\left.\$ 3^{\circ}\right)^{61}$. A lei n. 12.490 ainda estendeu a competência da ECT para além dos serviços postais convencionais, prevendo expressamente a possibilidade de a estatal explorar os serviços de logística integrada, financeiros e eletrônicos (art. 2º III, alíneas "a" a "c") e, obedecida a regulamentação do Ministério das Comunicações, firmar parcerias comerciais que agreguem valor à sua marca e proporcionem maior eficiência de sua infraestrutura, especialmente de sua rede de atendimento (art. $2^{\circ}$, parágrafo único).

\footnotetext{
${ }^{61}$ Quando do processo de conversão da MP n. 532 na lei n. ${ }^{\circ} 12.490 / 11$ foi inserida vedação a que essas empresas constituídas ou adquiridas atuem no mercado de entrega domiciliar de que trata o "monopólio" postal $\left(\operatorname{art.} 1^{\circ}, \S^{\circ}\right)$. Foi também acrescentado o dever de comunicação da constituição e aquisição à Câmara dos Deputados e ao Senado Federal no prazo máximo de 30 dias, contado da data da concretização do ato correspondente (art. $1^{\circ}, \S 6^{\circ}$ ).
} 
De outro lado, a lei n. ${ }^{\circ} 12.490$ estabeleceu ainda uma nova estrutura para a estatal $\left(\right.$ art. $3^{\circ}$ ), revogando previsões anteriores do decreto-lei (parágrafos $1^{\circ}$ a $4^{\circ}$ do art. $4^{\circ}$, parágrafo único do art. $3^{\circ}$ e artigos $8^{\circ}$ a 10 ), e previu a aplicação subsidiária da lei n. ${ }^{\circ}$ 6.404, de 15 de dezembro de 1976, que dispõe sobre as sociedades por ações (art. 21-A). Com essas medidas, de acordo com a exposição de motivos, pretende-se aumentar a transparência da estatal e o grau de controle sobre a empresa, e transferir ao Estatuto Social da ECT maior possibilidade de disciplinar a estrutura da estatal, permitindo-se maior flexibilidade ao seu fluxo decisório e gerencial ${ }^{62}$.

Ainda, de acordo com a exposição de motivos, com essas previsões a ECT intenciona também aperfeiçoar e aprofundar o atendimento às necessidades de seus clientes e ter sua disciplina jurídica mais próxima à incidente sobre as sociedades anônimas, com o que pretende ser aproximada das práticas organizacionais e de governança corporativa usadas em sociedades de economia mista como o Banco do Brasil e a Petrobras, constituídos na forma de sociedade por ações.

Na prática, as medidas adotadas pretendem possibilitar à ECT operar no exterior, oferecer serviços de telefonia, ter uma frota de aviões própria ou ter participação minoritária em outra já existente ${ }^{63}$, e associar-se a outras empresas e negócios, investindo, por exemplo, na construção do trem de alta velocidade (TAV ou "trem-bala", planejado para ligar as cidades de Campinas, São Paulo e Rio de Janeiro), tornando-se sócia do banco postal ou ainda se associando a outras empresas financeiras, de serviço de logística e postal eletrônico ${ }^{64}$.

\footnotetext{
${ }^{62}$ O novo Estatuto Social da ECT foi aprovado pelo decreto n. ${ }^{\circ} 7.483$, de 16 de maio de 2011.

${ }^{63}$ Conforme as entrevistas realizadas, atualmente é bastante tormentosa a questão do transporte aéreo postal. Isso porque se trata de recurso crítico para a estatal (é o meio através do qual se consegue garantir entregas num curto espaço de tempo), mas hoje ela apenas gerencia a rede, mas não a executa. Quer dizer, a ECT, por não ter uma frota de aviões própria, tem que ir ao mercado contratar aeronaves para proceder à distribuição, com capacidade para transportar os volumes de acordo com os trajetos que ela ECT especifica. Cabe a ela, estatal, gerenciar a rede aérea, planejando-a operacionalmente de acordo com o volume de objetos postais, "de-para" (ou seja, linhas A-B, B-A, A-B-A, A-B-C) etc., mas a execução dos serviços de transporte fica a cargo das empresas privadas de tráfego aéreo. O problema é que, dadas as limitações desse mercado de transporte aéreo de carga (e a própria expansão das empresas aéreas como concorrentes dos Correios), cada vez são menores as ofertas para a ECT, que precisa então de novas formas para lidar com esse recurso crítico, atendendo à demanda na entrega postal. Daí porque a MP autoriza que a ECT passe a ter uma frota de aviões própria ou constitua subsidiária para gerenciar esse recurso crítico, ou mesmo adquira o controle ou participação acionária em sociedades empresárias já estabelecidas.

${ }^{64}$ A esse respeito, ver notícia "Correios vão poder vender celular e comprar avião". De acordo com a reportagem, com sua superestrutura, a ECT poderá: “...oferecer serviços no exterior; ser operadora de
} 
O núcleo central das discussões do GTI e posteriores medidas aprovadas pela MP, convertida na lei n. ${ }^{\circ} 12.490$, assim, claramente demonstram voltar-se para a gestão da ECT, ainda que se possa ter em vista futuramente a avaliação do quadro maior do setor. Certamente essa análise do setor como um todo foi deixada para momento posterior e até o presente desconhece-se qualquer perspectiva concreta nesse sentido.

Partindo então da ideia desenvolvida por Maria Paula Dallari Bucci segundo a qual “...é sobre o direito que se assenta o quadro institucional no qual atua uma política"65 e de sua tentativa de formular um conceito jurídico de políticas públicas como sendo programas de ação governamental que objetivam coordenar os meios de que o Estado dispõe e as atividades privadas para a realização de objetivos definidos, relevantes e politicamente determinados, que expressem a seleção de prioridades, a reserva de meios necessários à sua consecução e o intervalo de tempo em que se espera atingir os resultados ${ }^{66}$, extrai-se que não há propriamente políticas públicas para o setor postal.

É dizer, as políticas públicas setoriais se confundem em grande medida com as políticas da empresa pública ECT, sem dúvida a maior prestadora do setor, mas não a única. Contra isso se pode argumentar que a pretensão inicial é implantar um projeto mais específico para o setor postal, de se resolver os problemas de gestão da ECT a fim de que ela passe a ser mais organizada, eficiente e modernizada, o que em certa medida impactaria o setor postal como um todo, indiretamente, inclusive pela posição de referência que ela ocupa no mercado.

Entretanto, o foco na sua gestão não serve per se para pautar todo o desenvolvimento do setor, inclusive em vista do fato de que há outros agentes econômicos atuando no mercado postal, sem se saber ao certo quais são os serviços que eles podem prestar e se podem, num regime de mercado. Assim, as políticas voltadas à ECT, a despeito de terem seu mérito, não devem ter o condão de assumir o espaço existente para as políticas públicas do setor postal como um todo. É necessário que para o setor sejam determinados objetivos claros e precisos, definidos os meios e prazos para empreendê-los.

celular móvel virtual; explorar serviços de logística, financeiros e postais eletrônicos; criar seu próprio banco postal; ter companhia aérea postal e associar-se a outras empresas e negócios, como o trem-bala".

${ }^{65}$ Maria Paula Dallari Bucci, "O conceito de política pública em direito". In: BUCCI, Maria Paula Dallari (org.). Políticas públicas: reflexões sobre o conceito jurídico, p. 37.

${ }^{66}$ Cf. Maria Paula Dallari Bucci, "O conceito de política pública em direito". In: BUCCI, Maria Paula Dallari (org.). Políticas públicas: reflexões sobre o conceito jurídico, p. 39. 
Ademais, essa "confusão" entre políticas do setor e a ECT (inexistente uma clara divisão de papéis de planejamento, execução, normatização, fiscalização e regulação no setor) pode acarretar problemas de governança à estatal e em relação à transparência com que ela se apresenta à sociedade civil. Esse, aliás, é um dos principais argumentos que sustentaram a privatização de diversos setores da economia brasileira na década de 1990 e, paralelamente, a ascensão de novos instrumentos regulatórios no processo de "reorganização do Estado" e sua consequente "republicização"67.

E mesmo em relação à ECT, parece que não há muita clareza por parte do próprio governo acerca do papel a ser exercido pela estatal nos próximos anos, faltando, assim, um planejamento consistente e adequado do setor. Como ela vem perdendo mercado (e receita), as medidas a ela voltadas envolveram desde especulações sobre a possibilidade de transformá-la em gestora das redes públicas que seriam utilizadas pela União no projeto de massificação da banda larga no Brasil ${ }^{68}$, até medidas, como as recentemente aprovadas pela MP n. ${ }^{\circ}$ 532, convertida na lei n. ${ }^{\circ}$ 12.490, que têm focos bastante diferentes entre si e propiciam que a ECT adote estratégias empresariais bastante distintas.

Neste sentido, há perspectivas de a ECT abrir agências no exterior, oferecer serviços de telefonia, operando nos moldes de operadora móvel virtual (MVNO) ${ }^{69}$, através do que os Correios comprariam das operadoras de celular espectro ocioso e venderiam aos seus clientes, com a marca Correios. É também possível que os Correios firmem parcerias ou mesmo criem empresa aérea para transporte de carga. Podem ainda participar da operação do trem de alta velocidade, seja na condição de sócios, seja ao menos como

\footnotetext{
${ }^{67}$ Neste sentido, Floriano de Azevedo Marques Neto: "Nesta perspectiva, da regulação da atividade pela reserva de sua exploração ao Estado, por óbvio, inexistia a separação entre regulador e operador da utilidade. A regulação (regulamentação, política tarifária, planejamento e expansão, fiscalização etc.) do serviço ou era feita internamente na própria operadora ou nos espaços estatais que a controlavam. Portanto, no contexto de intervenção direta, há uma confusão entre regulador e operador, o que torna muito pouco claros os parâmetros regulatórios. Daí ser a regulação marcadamente retrospectiva, conjuntural e mediada pela política." ("A nova regulação dos serviços públicos", Revista de Direito Administrativo, v. 228, p. 19-20). A referência a "Estado republicizado" remete à obra de Floriano de Azevedo Marques Neto, Regulação estatal e interesses públicos, p. 183. A expressão é utilizada pelo autor com a intenção de demarcar a passagem de um modelo de Estado marcado por um forte intervencionismo direto para um modelo no qual o Estado intervém indiretamente no jogo econômico, regulando os campos da atividade econômica e social, mas não executando diretamente as atividades que podem ser desenvolvidas por atores privados.

${ }^{68}$ Notícia "MP que cria Correios S.A. deve sair hoje".

${ }^{69}$ Cf. notícia "Correios vão poder vender celular e comprar avião".
} 
clientes $^{70}$, medidas que se justificariam para que o projeto TAV se tornasse mais atraente e uma vez que a entrega de correspondências e mercadorias no eixo Rio de Janeiro - São Paulo representa grande parte do volume de depósitos (faturamento) da estatal.

Todas essas medidas, que impactam de maneira significativa a estatal e o setor como um todo, parecem estar sendo adotadas sem um planejamento adequado, voltado não apenas a aprimorar o viés empresarial da empresa pública, como também as políticas sociais que ela desenvolve e a discussão mais ampla do que o Brasil espera, planeja e pensa para o setor postal, como ele enxerga o setor postal articulado com outras forças econômicas, sociais e políticas, de maneira que o setor postal também possa, em sinergia com outros setores, promover o desenvolvimento econômico e social do país.

A este respeito, chama atenção o fato de inicialmente ter sido utilizado o instrumento normativo medida provisória para implementação de alterações profundas, especialmente no que toca à gestão da estatal. Embora se possa argumentar que o uso de medida provisória para a elaboração de políticas públicas não necessariamente significa um alheamento do Congresso Nacional, é de se questionar se o uso desse instrumento nesse caso não denota no mínimo uma preocupação secundária de se implantar políticas consistentes para o setor. Não apenas porque as alterações são profundas, e feitas no mesmo texto que propõe uma série de alterações no setor de combustíveis - em nada relacionado ao setor postal -, como também por ser possível questionar nesse caso os requisitos de "relevância e urgência" prescritos pela Constituição Federal para adoção desse instrumento (art. 62).

Com relação a este aspecto, a exposição de motivos da medida provisória n. 532 justifica a "relevância e urgência" de sua adoção em vista do "sério risco à própria sustentabilidade da Empresa no curto prazo", por conta da perda substancial de receitas com a progressiva substituição da comunicação física por eletrônica e pelos graves problemas operacionais vividos pela ECT para transporte relacionado à carga postal. A solução desses entraves, conforme o texto da exposição, demandaria ações para sanar deficiências de infraestrutura e o desenvolvimento de linhas de serviços capazes de gerar novas receitas.

${ }^{70}$ Cf. notícia "Correios mantêm interesse no trem-bala". Ver também "Governo inclui Correios no trembala". 
Mas será mesmo que há um risco iminente à ECT de modo a justificar a adoção de uma MP? Se alterações normativas são necessárias, não seria o caso de observar-se o trâmite legislativo "ordinário"? E, por ser um setor importante para o país, não seria o caso de aprimorar as discussões e o debate público para que políticas mais consistentes sejam adotadas? É mais legítimo e eficiente que as políticas sejam definidas unilateral e exclusivamente a partir dos espaços decisórios estatais, e a partir de um trâmite mais apressado que possibilita menos análise e avaliação? Será que focar em respostas de curto e médio prazo para a ECT cumpre o papel de melhor normatizar o setor como um todo? E será que os problemas da ECT circunscrevem-se à sua gestão, não se relacionando aos outros atores envolvidos no setor e, pois, com uma discussão mais ampla do setor como um todo?

A reflexão sobre essas questões e a constatação de que, apesar de sua importância, em grande medida o setor postal tem sido colocado em segundo plano, seja no cenário de discussões acadêmicas, seja no que se refere a discussões governamentais, justificam a assertiva de que há um cenário de descaso em relação ao setor postal brasileiro. Tanto por parte dos estudiosos do direito, quanto por parte do próprio governo não tem havido uma preocupação clara e consistente com o setor. A literatura sobre o tema é muito escassa, a judicialização dos conflitos no setor é reiterada, não há propriamente políticas setoriais, e o debate sobre o setor é praticamente inexistente.

\section{III.2.2. Necessidade de um arranjo institucional: vetores que denotam a importância do setor}

A partir desse cenário de descaso em relação ao setor postal brasileiro e admitindose, nesse contexto, como verdadeira a premissa de que o setor postal não é o único capaz de proporcionar a integração nacional e mesmo internacional das comunicações, procurarse-á a seguir explorar a ideia segundo a qual, mesmo na conjuntura atual das comunicações brasileiras, o setor postal (e a ECT) exerce um papel importante para o país, razão pela qual políticas relacionadas ao setor devem fazer parte da agenda nacional ${ }^{71}$.

\footnotetext{
${ }^{71}$ Ainda que entendêssemos que a ECT não tem qualquer importância (o que não é o caso), seria possível sustentar que mesmo assim o debate seria relevante, pois nesse cenário seria necessário vender seus ativos e extinguir a empresa.
} 
Essa ideia será abordada a partir da análise crítica de três vetores que denotam a importância do setor postal e a necessidade de existir uma preocupação institucional, quais sejam: a amplitude dos serviços postais, as ações sociais e relevância econômica da empresa pública ECT e a capilaridade do serviço postal.

\section{III.2.2.1. Amplitude dos serviços postais}

Um primeiro vetor relaciona-se à amplitude dos serviços postais. O setor postal não se resume à prestação de serviços de carta e telegrama, tradicionais serviços ofertados pelos Correios. Quando se faz uma compra pela internet, a encomenda é entregue por uma prestadora de serviços postais. Quando se recebe em casa um talão de cheque, um cartão de crédito, eles são entregues por uma prestadora de serviços postais (ou ao menos o banco terá celebrado com a ECT um contrato para o franqueamento autorizado de cartas - FAC). Os exemplos são vários e capazes de, em última instância, revelar ainda hoje uma importância estratégica do setor postal, ainda que atualmente ele não seja imprescindível à soberania nacional. Capítulo próprio (Capítulo 2) tratará do alargamento dos serviços postais e dos efeitos jurídicos que dele derivam.

\section{III.2.2.2. Empresa pública ECT: ações sociais e relevância econômica}

Um segundo vetor relaciona-se à importância da empresa pública ECT, em razão de suas ações sociais e relevância econômica. Contraditoriamente a essa importância da estatal, a falta de regras claras também a tem prejudicado ${ }^{72}$. E o próprio descaso com o setor, inclusive em termos de políticas setoriais e de gestão da empresa, tem feito com que uma empresa tida por vários anos como uma das instituições que mais inspiram confiança aos brasileiros ${ }^{73}$ esteja hoje sofrendo diversas críticas em razão de atrasos na entrega de

\footnotetext{
${ }^{72}$ Certamente há também problemas de gestão da estatal. Porém, entendo que a falta de regras claras não prejudica apenas o setor privado. Se, por exemplo, não se sabe ao certo qual é o alcance do "monopólio" da ECT, isso acarreta também um ônus para a estatal. Poderá se valer do privilégio do "monopólio" postal? Pode (e deve) lutar contra a proliferação de prestadoras privadas? De que maneira capacitar a estatal para melhor competir com as empresas privadas nas áreas em que inexiste exclusividade? Essas são algumas das questões que ficam em aberto e que a meu ver demonstram que a falta de regras claras para o setor também prejudica a ECT.

${ }^{73}$ Nesse sentido, o "Relatório Empresarial e Social da ECT de 2008" aponta que no ano em pesquisa do Ibope Solutions a empresa foi eleita pelo sétimo ano consecutivo como a instituição que mais inspira confiança aos brasileiros.
} 
documentos, na realização de concursos e de licitação das agências franqueadas ${ }^{74}$, e até mesmo em razão de possíveis práticas de corrupção ${ }^{75}$.

A falta de regras claras e de políticas consistentes (inclusive para a gestão da estatal) prejudica não apenas o viés empresarial da empresa pública (seu figurino privado), como também a missão pública que lhe é inerente. E há uma série de políticas sociais que vêm sendo prestadas pela estatal como entidade integrante da estrutura orgânica do Estado. A partir da legislação setorial, do site da empresa e dos seus relatórios institucionais, procurou-se mapear as ações sociais da ECT, com vistas a demonstrar que há razões para que a estatal em si e o setor como um todo deixem de ser colocados em segundo plano pelos órgãos governamentais.

No final de 2003 foi editada a lei n. ${ }^{\circ} 10.753$, com o objetivo de estimular a criação e execução de projetos voltados para o acesso a livros e incentivo à leitura. Dentre as medidas adotadas, previu a competência do Poder Executivo para estabelecer tarifa postal preferencial, reduzida, para o livro brasileiro. Atualmente a ECT, em parceria com o Fundo Nacional de Desenvolvimento da Educação (FNDE), vem utilizando sua estrutura logística para realizar o Programa Nacional do Livro Didático (PNLD) e o Programa Nacional do Livro Didático para o Ensino Médio (PNLEM). Conforme o Relatório Empresarial e Social da ECT de 2008, neste ano a operação distribuiu 103 milhões de livros didáticos (o que equivale à metade de toda a produção gráfica do país), sendo que o kit de livros entregues pelos Correios atendeu cerca de 34 milhões de alunos de 140 mil escolas públicas do país ${ }^{76}$.

\footnotetext{
${ }^{74}$ A esse respeito, ver "O que fizeram com os Correios" e editorial "Correio Político".

${ }^{75}$ Sobre o tema, ver "Procuradoria denuncia Jefferson e mais oito por escândalo dos Correios".

${ }^{76}$ No site da ECT há informação de que serão entregues 89 milhões de livros didáticos em 153.900 escolas, em 4.863 municípios, e de que essa entrega no âmbito do Programa Nacional do Livro Didático “...está sendo considerada a maior operação logística envolvendo livros didáticos de que se tem notícia em todo o mundo". Disponível em: <http://www.correios.com.br/institucional/conheca_correios/conheca.cfm>. Acesso: 21.06.2010.
} 
O serviço de cartas é diferenciado em modalidades (carta social, carta não comercial e carta comercial, remetida por pessoa jurídica). A tarifa da chamada carta social é de apenas um centavo $(\mathrm{R} \$ 0,01)^{77}$. Há projetos que visam a estimular a redação de cartas manuscritas por crianças, posteriormente respondidas por voluntários dos Correios (Projeto Papai Noel dos Correios); há projetos que visam a incentivar o aleitamento materno (Projeto Carteiro Amigo) ${ }^{78}$, a partir do treinamento de carteiros e repasse de informações básicas e distribuição de panfletos instrutivos.

Há programas voltados ao desenvolvimento de atividades socioeducativas remuneradas para adolescentes, portadores de necessidades especiais e apenados, para que tenham condições de serem absorvidos pelo mercado de trabalho após desligamento do programa dos Correios $^{79}$. Há grupos de coral da ECT (Projeto Todos os Cantos do Brasil), Museu Nacional dos Correios, Centros e Espaços Culturais Correios (no Rio de Janeiro, em Recife, em Salvador, em Juiz de Fora e Fortaleza). Há, por assim dizer, razões de ordem social para que existam preocupações em relação ao setor postal.

Mesmo do ponto de vista econômico, os números da estatal ainda hoje são significativos. No ano de 2008, por exemplo, o volume de depósitos (faturamento) da ECT girou em torno de $\mathrm{R} \$ 800$ milhões, dos quais $\mathrm{R} \$ 120$ representaram resultados positivos (lucratividade da empresa) ${ }^{80}$. Nesse sentido, também ainda hoje há relevância econômica na prestação dos serviços postais.

\footnotetext{
77 A portaria n. ${ }^{\circ} 245$, de 09 de outubro de 1995, caracteriza a carta social da seguinte forma: (i) limite máximo de peso igual a 10 gramas; (ii) endereçamento manuscrito contendo a indicação carta social; (iii) franqueamento por meio de selo postal adesivo ou estampa de máquina de franquear. A referência à tarifa de R\$ 0,01 da carta social advém da portaria n. ${ }^{\circ} 1.061$, de 29 de dezembro de 2009.

${ }^{78}$ Pelas pesquisas realizadas, o Projeto Carteiro Amigo foi executado entre os anos de 1999 a 2002.

${ }^{79}$ Conforme o "Balanço Social dos Correios 2005", neste ano cerca de 8.000 pessoas tiveram a oportunidade de participar da política de inclusão social da empresa. Ainda segundo o relatório, "As vagas reservadas em edital de concurso público para ingresso nos Correios de pessoas com deficiência, superam em muito os $5 \%$ exigidos pela legislação: $20 \%$ é o percentual estabelecido pela empresa".

${ }^{80}$ Cf. "Relatório Empresarial e Social da ECT 2008". Constam do site oficial dos Correios "Relatórios e Balanços Sociais" atualizados até o ano de 2008. Estão também disponíveis no site demonstrações financeiras atualizadas até o ano de 2010. Segundo a notícia "Correios registram lucro de R\$ 499,6 mi no semestre", "Os Correios registraram lucro líquido de $R \$ 499,65$ milhões no primeiro semestre de 2011, valor 48,2\% superior ao obtido no primeiro semestre do ano passado. De acordo com dados divulgados há pouco pela Empresa Brasileira de Correios e Telégrafos (ECT), houve expansão de 11,72\% nas receitas nos primeiros seis meses do ano, enquanto as despesas aumentaram 9,44\%".
} 


\section{III.2.2.3. Capilaridade do serviço postal}

Um terceiro vetor que denota a importância do setor postal relaciona-se à capilaridade do serviço postal. Nas últimas décadas o setor de telecomunicações alcançou uma significativa ampliação junto à sociedade, mas a universalização do setor ainda hoje é uma tarefa inacabada ${ }^{81}$. Há uma forte pressão política para que os níveis de penetração da internet também se ampliem significativamente (daí a preocupação com o plano nacional de banda larga ${ }^{82}$ ), mas esse programa ainda demandará longos anos de maturação.

Diante disso, embora possa causar estranhamento, ainda hoje há regiões do Brasil em que só há a prestação de serviços postais, e básicos. Segundo o relatório Balanço Social dos Correios $2005^{83}$, os Correios eram à época a única instituição presente em todos os municípios brasileiros.

81 Cf. Alexandre Ditzel Faraco; Caio Mário da Silva Pereira Neto; Diogo Rosenthal Coutinho, "Universalização das telecomunicações no Brasil: uma tarefa inacabada", Revista de Direito Público da Economia, n. ${ }^{\circ}$ 2, p. 18. Os autores chamam atenção para a significativa inclusão social alcançada nos últimos anos no setor de telecomunicações, a partir do processo de privatização e liberalização do setor, acompanhado de uma política de universalização. Apesar disso, no entanto, eles argumentam que o Brasil ainda está longe de atingir os níveis ideais de acesso, especialmente por dois motivos: (i) houve uma expansão da cobertura e capilaridade das redes de infraestrutura de telecomunicações, mas ainda há usuários pouco atrativos que não desfrutam desse benefício (residentes em localidades remotas que apresentam alto custo de implantação e operação de infraestrutura); e (ii) muitos usuários integrados ao "sistema" enfrentam dificuldades para pagar suas contas telefônicas (são consumidores de baixa renda, cujo problema de acesso relaciona-se à sua capacidade aquisitiva), o que os torna expostos a riscos de desconexão.

${ }^{82}$ O Programa Nacional de Banda Larga (PNBL) foi recentemente instituído pelo decreto n. ${ }^{\circ}$ 7.175, de 12 de maio de 2010.

${ }^{83}$ Disponível em:

<http://www.correios.com.br/institucional/conheca_correios/balanco_social/arquivo/balanco_social_2005[2]. pdf>. Acesso: 26.06.2010. 
Em 2006, a União Postal Universal premiou uma brasileira por ter escrito uma carta que retratava a experiência que tinha tido na Comunidade Chico Mendes, no Amazonas. O telefone estava estragado, a internet não alcançava a localidade remota, e as pessoas da região substancialmente recorriam ao setor postal para se comunicarem. A "Casa dos Correios" não existia no lugar, e seus "encarregados" navegavam, carregando as mercadorias, por uma hora no rio Solimões até chegar ao local ${ }^{84}$. Conforme o relato, na Comunidade os Correios desempenham um papel que vai além da prestação de serviços postais convencionais. Os Correios servem como uma verdadeira forma de escoamento da produção da população da região, possibilitando inclusive a venda de seus produtos.

A despeito da grande capilaridade do setor postal, ainda hoje há um déficit de universalização no setor. Conforme o Relatório Empresarial e Social da ECT de 2008, neste ano cerca de 30 milhões de brasileiros não tinham serviços postais adequados às suas necessidades de comunicação. Por essa razão, o debate sobre o tema da universalização do setor postal ainda hoje merece ser objeto de preocupação institucional, embora se trate de um problema que não é eminentemente econômico e social, por vezes revelando-se como um problema geográfico.

\footnotetext{
${ }^{84} \mathrm{Na}$ carta premiada pela União Postal Universal (Universal Postal Union), da brasileira de 14 anos Laura de Paula Silva, ela conta a experiência que teve na Comunidade Chico Mendes, Amazonas, nos seguintes termos: "Depois que me instalei, o natural era buscar comunicação com a minha família. Procurei por um telefone, mas este encontrava-se estragado. Lembrei-me do computador e da Internet. No entanto, eles não tinham contato com esse meio, já que a Internet não alcançava aquela localidade remota e praticamente extinta do mapa e das estatísticas. (...) Aqui na Comunidade Chico Mendes, as pessoas vivem basicamente do artesanato e na busca de mercado, recorrem ao sistema postal. Toda semana e em todas as comunidades vizinhas, encarregados dos Correios driblam uma infinidade de obstáculos para chegarem até aqui. Como na sede municipal, aqui nas proximidades não existe a Casa dos Correios, os encarregados vêm no caminhão de uma cidade maior até a sede municipal. Em seguida navegam uma hora pelo Rio Solimões até chegarem até aqui. Carregam a embarcação com as mercadorias e refazem o percurso. O que seria dessas famílias se não existisse o sistema postal? Como venderiam seus produtos? O sistema postal é a única maneira desse povo escoar sua produção e ficar a par dos acontecimentos externos" (Primeiro prêmio do concurso epistolar 2006. Disponível em: <http://www.upu.int>. Acesso: 04.10.2008).
} 


\section{CAPÍTULO 2 - CONTEÚDO DOS SERVIÇOS POSTAIS}

\section{IV.1. Definição dos serviços postais na legislação postal: delimitação dos serviços com foco na ECT}

Tendo sido descrita, em linhas gerais, a realidade do setor postal no Brasil (Capítulo 1), neste Capítulo 2 procurar-se-á delimitar o conteúdo dos serviços postais, que sofreu um grande alargamento ao longo dos últimos anos. Servirão de pano de fundo para a análise fundamentalmente duas questões: o que são serviços postais, e quais efeitos jurídicos derivam dessa ampliação dos serviços prestados como postais. O ponto de partida para responder a essas indagações será a análise da legislação postal.

O decreto-lei n. ${ }^{\circ}$ 509/69 apenas conferia à ECT competência para executar e controlar, em regime de "monopólio", os serviços postais - sem defini-los -, em todo o território nacional, e exercer as atividades definidas em seus artigos 15 e 16, relacionadas a telecomunicações $^{85}$ (art. $2^{\circ}$, I e II). Mais recentemente, a medida provisória n. ${ }^{\circ}$ 532/11, convertida na lei n. ${ }^{\circ} 12.490$, incorporou ao texto do decreto-lei a competência da ECT para explorar os serviços de logística integrada, financeiros e postais eletrônicos (art. $2^{\text {o }}$, III) e para firmar parcerias comerciais que agreguem valor à sua marca e proporcionem maior eficiência de sua infraestrutura, especialmente de sua rede de atendimento (art. $2^{\circ}$, parágrafo único).

Portanto, afora a referência às atividades de telecomunicações, a serem exercidas de forma residual pela ECT, e a recente atribuição à estatal da competência para explorar serviços de logística integrada, financeiros e postais eletrônicos - cuja definição precisa não consta da MP convertida em lei, não tendo sido incorporada, portanto, ao decreto-lei -, não há nesta norma delimitação de quais são os serviços englobados como postais.

\footnotetext{
85 “Art. 15 - Ressalvadas a competência e jurisdição da Empresa Brasileira de Telecomunicações (EMBRATEL), a ECT, como sucessora ao DCT, poderá prosseguir na construção, conservação e exploração dos circuitos de telecomunicações, executando os serviços públicos de telegrafia e demais serviços públicos de telecomunicações, atualmente a seu cargo.

Art. 16 - Enquanto não forem transferidos, para a EMBRATEL, os serviços de telecomunicações, que o Departamento dos Correios e Telégrafos hoje executa, a ECT, mediante cooperação e convênio com aquela empresa, poderá construir, conservar ou explorar, conjunta ou separadamente os circuitos-troncos que integram o Sistema Nacional de Telecomunicações".
} 
A única lei que demarca o que são os serviços postais é a lei n. ${ }^{\circ}$ 6.538/78. Mesmo assim, ela diz o que são os serviços com a finalidade clara de delimitar o objeto de exploração da ECT - tal como faz o decreto-lei ao tratar das competências da estatal -, como se ela fosse a única prestadora dos serviços postais, mesmo nas áreas não "monopolizadas" 86 . São dois os serviços que a lei prevê que seriam explorados pela ECT: o serviço postal e o serviço de telegrama (art. $2^{\circ}$, caput).

Dentro de serviço postal foram englobadas pela lei as atividades de recebimento, expedição, transporte e entrega de objetos de correspondência (carta, cartão-postal, impresso, cecograma e pequena-encomenda), valores (remessa de dinheiro através de carta com valor declarado, remessa de ordem de pagamento por meio de vale postal e recebimento de tributos, prestações, contribuições e obrigações pagáveis à vista, por via postal) e encomendas (remessa e entrega de objetos, com ou sem valor mercantil, por via postal).

Dentro de serviço de telegrama foram englobadas pela lei as atividades de recebimento, transmissão e entrega de mensagens escritas. A lei ainda previu que a ECT poderia explorar atividades correlatas (como a venda de selos, peças filatélicas, exploração de publicidade comercial em objetos de correspondência) $)^{87}$ e exercer outras atividades afins, autorizadas pelo Ministério das Comunicações (art. $2^{\circ}, \S^{\circ}$ ).

\footnotetext{
86 “Art. $2^{\circ}$ - O serviço postal e o serviço de telegrama são explorados pela união, através da empresa pública vinculada ao Ministério das Comunicações. $\$ 1^{\circ}$ - Compreende-se no objeto da empresa exploradora dos serviços: a) planejar, implantar e explorar o serviço postal e o serviço de telegrama; b) explorar atividades correlatas; c) promover a formação e o treinamento de pessoal sério ao desempenho de suas atribuições; $d$ ) exercer outras atividades afins, autorizadas pelo Ministério das Comunicações".

${ }^{87}$ Atividades correlatas relacionadas tanto ao serviço postal quanto ao serviço de telegrama.

"Art. $8^{\circ}$ - São atividades correlatas ao serviço postal: I - venda de selos, peças filatélicas, cupões resposta internacionais, impressos e papéis para correspondência; II - venda de publicações divulgando regulamentos, normas, tarifas, listas de código de endereçamento e outros assuntos referentes ao serviço postal; III - exploração de publicidade comercial em objetos [de] correspondência. Parágrafo único - A inserção de propaganda e a comercialização de publicidade nos formulários de uso no serviço postal, bem como nas listas de código de endereçamento postal, é privativa da empresa exploradora do serviço postal".

"Art. 26 - São atividades correlatas ao serviço de telegrama: I - venda de publicações divulgando regulamentos, normas, tarifas, e outros assuntos referentes ao serviço de telegrama; II - exploração de publicidade comercial em formulários de telegrama. Parágrafo único - A inserção de propaganda e a comercialização de publicidade nos formulários de uso no serviço de telegrama é privativa da empresa exploradora do serviço de telegrama".
} 
Em razão da abrangência e complexidade que os serviços postais alcançaram especialmente nas últimas décadas, fruto em grande medida das transformações nas comunicações brasileiras, essas previsões legais parecem ter se afastado bastante da realidade, especialmente quando se procura subsumir um dado serviço à legislação, editada numa época em que a complexidade das atividades postais era sensivelmente diversa. A esse respeito, chama atenção a dificuldade atualmente existente para se delimitar o campo dos serviços postais "monopolizados" (para além da questão que também se coloca sobre a própria existência de um “monopólio" postal), discussão da qual se ocupará o Capítulo 3, e que envolve saber, por exemplo, se um cheque é uma encomenda (e como tal não “monopolizado") ou se é uma carta (sobre a qual se estende o regime de exclusividade).

Paralelamente à ampliação da abrangência dos serviços postais e de sua maior complexidade, assiste-se a uma evolução da demanda dos serviços prestados no setor (por exemplo, no perfil dos usuários vinculados aos serviços, e no padrão de consumo) e do seu volume de depósitos (faturamento) (por exemplo, a evolução do faturamento do setor como um todo e da ECT em particular nos últimos anos, e a mudança do rol de atividades que são mais lucrativas e menos lucrativas ou mesmo deficitárias).

A partir da leitura dos dispositivos legais, das transformações por que tem passado o setor e desses conflitos nele existentes, constata-se que a legislação postal é insuficiente para precisar de modo claro o que são serviços postais e a evolução do setor. Talvez a especificação detalhada de quais são todos os serviços que podem ser prestados por operadoras do setor nem seja mesmo o papel da legislação, que pode restringir-se a dar os contornos gerais da atividade. Isso gera a importância de se verificar na prática quais atividades são prestadas como postais, tendo em vista que o regime jurídico de determinado setor da economia é concebido considerando o conteúdo dos serviços que engloba.

\section{IV.2. Distanciamento da lei em relação à realidade dos serviços prestados pela ECT: a criação de uma verdadeira rede postal}

Cabe, pois, investigar quais são os serviços que uma prestadora de serviços postais oferece à sociedade. Nos limites desta dissertação de mestrado, esta avaliação prática será feita em relação à ECT. 
A despeito deste recorte do objeto de pesquisa, necessário pontuar que há dificuldade em se delimitar quais atividades que os demais prestadores do setor postal podem desempenhar. No caso dos prestadores que estabeleceram com a ECT um vínculo contratual, uma parceria de propagação da rede pública "Correios", caso das agências de correio franqueadas, permissionárias e das agências postais comunitárias, dada a ingerência que a ECT exerce sobre suas atividades, os contratos celebrados e a legislação infralegal impõem limitações, em relação às fases do ciclo postal em que essas prestadoras podem atuar e aos serviços que podem prestar. Essas limitações serão referidas de maneira geral ao longo deste capítulo.

Já no caso das empresas de distribuição, como elas convivem competitivamente com a ECT, sem qualquer vínculo de outorga ou parceria, suas atividades empresariais não se submetem a ingerências da estatal, salvo quando esta, ao exercer seu poder de polícia, entende que essas empresas estão violando o "monopólio" postal que lhe foi conferido pela legislação. O Capítulo 3 tratará especificamente do tema da exclusividade da prestação pela ECT de alguns serviços postais.

De maneira geral, no entanto, as alterações no mercado postal também impactam nos serviços prestados por esses agentes econômicos. Na medida em que alguns segmentos do mercado postal estão se tornando menos lucrativos do que outros, a tendência é que os prestadores do setor busquem aprimorar sua atuação nos mais lucrativos. Deveras, na sociedade brasileira é a partir da troca que se estabelecem as relações entre os diferentes atores sociais (economia de mercado) e o funcionamento do mercado de forma eficiente pressupõe que seja conferida aos agentes econômicos certa dose de liberdade, o que não impede, no entanto, que o Estado garanta institucionalmente o equilíbrio entre os agentes econômicos, regulando suas atividades ${ }^{88}$.

Em relação à ECT, conforme seu Relatório Empresarial e Social de 2008, a estatal hoje atua em vários segmentos de negócios: digital, logística, malote, mensagem, encomenda, financeiro, internacional, conveniência e marketing direto.

\footnotetext{
${ }^{88}$ Ver a respeito Tiago Machado Cortez, Moeda, Estado e Direito: o papel do Estado na ordem monetária e seu controle, p. 20.
} 
São prestados serviços ${ }^{89}$ de mensagens, como cartas (inclusive via internet) e telegramas (fonados, captados via web e em agências); marketing direto, que possibilita, a partir da definição de um público-alvo, a venda à distância por meio de catálogos, malas diretas ou serviços on-line. Há todo um sistema de envio de encomendas (PAC, modalidade de encomenda não expressa; e encomenda customizada, produto oferecido a grandes clientes para distribuição em operações especiais, como é o caso dos livros didáticos do MEC), de impressos (como livros, revistas, jornais, prospectos de propaganda), de remessa de documentos dos órgãos de trânsito, de talões de cheque e cartões magnéticos (serviço destinado, por exemplo, a bancos, financeiras, administradoras de cartões de crédito, companhias aéreas, cadeias de hotéis, empresas de telefonia). É oferecido o Serviço de Encomenda Expressa Nacional (Sedex), atualmente prestado por várias modalidades (Sedex, Sedex Hoje, Sedex 10, Sedex Mundi, Conta Sedex).

Há diversos serviços de conveniência, como inscrições para concursos públicos e vestibulares (para instituições públicas e privadas), declaração de imposto de renda e de isentos e emissão de Cadastro de Pessoa Física (CPF). A ECT oferece às pessoas jurídicas que postem grande quantidade de correspondência o franqueamento autorizado de cartas $\left(\mathrm{FAC}^{90}\right)$. Conforme informações no site da ECT, a estatal tem buscado efetivar parcerias com concessionárias de serviços públicos (de água, luz e telefone) e órgãos governamentais para que contas e tributos sejam pagos nas agências do correio. Já estão sendo prestados serviços financeiros, como o Vale Postal (remessa de valores via correio, através de ordem de pagamento), o Dinheiro Certo (para enviar ou receber dinheiro no Brasil ou no exterior) e o pagamento de aposentados do INSS.

\footnotetext{
${ }^{89}$ O catálogo completo e detalhado de produtos e serviços oferecidos pela ECT encontra-se disponível em $<$ http://www.correios.com.br/produtos_servicos/catalogo/catalogo_prod_serv.cfm>. Acesso: 22.06.2010.

${ }^{90}$ A portaria n. ${ }^{\circ}$ 518, de 02 de outubro de 2003, dá contornos para o estabelecimento de metas e ações para a modernização tecnológica do processo de franqueamento dos objetos postais, por meio de máquinas de franquear. Nos termos da portaria, o franqueamento volta-se à rede de atendimento própria, franqueada e permissionária.
} 
Em 2002 foi lançado o Banco Postal, inicialmente uma parceria com o Bradesco ${ }^{91} \mathrm{e}$ a partir do início do ano de 2012 com o Banco do Brasil, que se caracteriza pela utilização da rede de atendimento da ECT para a prestação de serviços bancários básicos ${ }^{92}$. Nos termos da portaria que instituiu o serviço, ele deveria ser implantado prioritariamente nos municípios desassistidos de atendimento bancário. A meta inicialmente prevista para o Plano de Implantação dos Serviços nos Municípios sem atendimento bancário era até dezembro de 2003 (art. 5, II).

Segundo notícia do jornal $O$ Estado de São Paulo ${ }^{93}$, publicada em fevereiro de 2010, com o Banco Postal já haviam sido abertas 9,2 milhões de contas e havia uma movimentação de $\mathrm{R} \$ 40$ bilhões. Conforme a notícia, na última reformulação do contrato com o Bradesco ele havia pago à ECT R 150 milhões e com a parceria o rendimento anual pago à ECT é de R\$ 250 milhões.

Posteriormente, em notícia publicada no jornal Folha de São Paulo em junho de $2011^{94}$, afirma-se que desde o início das atividades do Banco Postal o Bradesco teve 11 milhões de contas nas unidades dos Correios, e um volume de depósitos (faturamento) em 2010 que chegou a R\$ 820 milhões. No final de maio de 2010, ocorreu o leilão para a escolha do novo parceiro dos Correios para o Banco Postal, no qual, tendo dado o lance de R\$ 2,30 bilhões (valor bastante superior ao ofertado pelo Bradesco em 2002, de R\$ 200 milhões), o Banco do Brasil ganhou o direito de ofertar serviços bancários nas agências dos Correios, a partir de 02 de janeiro de $2012^{95}$.

\footnotetext{
${ }^{91}$ Nos termos da portaria n. ${ }^{\circ} 588$, de 04 de outubro de 2000, que instituiu o banco postal, a contratação deve ser precedida de processo seletivo público, "caso a prática recomende a prestação dos serviços com uma única instituição parceira" (art. $2^{\circ}, 3^{\circ}$ ).

${ }^{92}$ Típicos serviços bancários, como se vê do art. $4^{\circ}$ da portaria n. ${ }^{\circ}$ 588, de 04 de outubro de 2000: "Art. $4^{o}$ Na qualidade de correspondente, a ECT poderá prestar um ou mais dos seguintes serviços, em comum acordo com as instituições parceiras: I - recepção e encaminhamento de propostas de abertura de contas de depósito à vista, a prazo e de poupança; II - recebimentos e pagamentos relativos a contas de depósitos à vista, a prazo e de poupança, bem como aplicações e resgates em fundos de investimento; III - recebimentos e pagamentos decorrentes de convênios de prestação de serviços mantidos pelo banco parceiro, na forma de regulamentação em vigor; IV - execução ativa ou passiva de ordens de pagamento em nome do banco parceiro; $V$ - recepção e encaminhamento de pedidos de empréstimos e de financiamentos; VI - análise de crédito e cadastro; VII - execução de cobrança de títulos; VIII - outros serviços de controle, inclusive processamento de dados, das operações pactuadas; e IX - outras atividades, a critério do Banco Central do Brasil. Parágrafo único. A prestação dos serviços referidos nos incisos I e II deste artigo depende de prévia autorização do Banco Central do Brasil".

${ }^{93}$ Cf. notícia "Modernização dos correios prevê agências no exterior".

${ }^{94}$ Cf. notícia "BB desbanca Bradesco e leva Banco Postal".

${ }^{95}$ Cf. notícias "BB desbanca Bradesco e leva Banco Postal" e "Leilão para banco parceiro dos Correios será no dia 31 de maio".
} 
Há serviços adicionais como o Seguro Complementar (pelo qual o cliente declara o valor de mercadorias e outros objetos de valor, postados sob registro, para fins de ressarcimento), o Aviso de Recebimento (que permite comprovar ao remetente para quem foi entregue o objeto por ele postado) e o serviço Mão Própria (pelo qual o remetente recebe a garantia de que o objeto por ele postado será entregue exclusivamente ao destinatário). São oferecidos acessórios especiais, como a Caixa Postal (pode-se alugar uma caixa postal) e a Posta Restante (que possibilita o recebimento, na agência postal conveniente, de todas as correspondências para ali enviadas em nome do cliente).

Há um segmento internacional, que oferece serviços de Correio Internacional (com as modalidades de serviços Sedex Mundi, Serviço Expresso, Serviço Prioritário, Serviço Econômico), Exporta Fácil (serviço de exportação dos correios) e Importa Fácil (serviço de importação dos Correios).

Os Correios também estão disponibilizando serviço de rastreamento de objetos (ainda só em âmbito nacional). Além disso, são oferecidos produtos de conveniência, como aerogramas (nacional, internacional e comemorativo), embalagens (envelopes para cartas e caixas), filatélicos (várias modalidades de selos, carimbos e cartões-postais) e produtos personalizados (como carimbos comemorativos e a griffe via postal, que reúne sob sua marca produtos como agendas, cadernos e camisetas).

O Correios $\log ^{96}$ é o serviço de logística integrado aos Correios, que objetiva modelar os contratos de logística de acordo com as necessidades dos usuários, referentes à remessa de bens e documentos pela via postal. Por meio desse serviço, desde 2002 os Correios têm gerenciado atividades da cadeia de valor de alguns clientes corporativos, desempenhando, de acordo com a estratégia de logística e marketing desses clientes, atividades como recebimento, armazenagem, expedição, transporte, distribuição e logística reversa. São até definidas áreas de atuação dos Correios: editoras/ensino à distância, telefonia celular, som/vídeo, governo, bancos, medicamentos e cosméticos.

\footnotetext{
${ }^{96}$ O Serviço de Logística Postal Integrada a ser prestado pela ECT foi criado pela portaria n. ${ }^{\circ} 500$, de 06 de dezembro de 2004. Nos termos da portaria, o serviço compreende, entre outras, as seguintes atividades: "I recebimento de pedidos, coleta, tratamento, manuseio, armazenagem, postagem, transporte de transferência e de distribuição e entrega de bens e documentos, de forma fracionada ou consolidada, sem limite de peso; II - serviço de informação, por meio de sistema de comunicação, de processamento de dados e de controle; $e$ III - serviços financeiros postais".
} 
Em 2002 foi editada a portaria n. ${ }^{\circ} 2.589$, de 26 de novembro de 2002, criando um serviço especial de comercialização de seguros, previdência privada e títulos de capitalização, denominado Seguro Postal. Com base nessa previsão, houve até a publicação de um chamamento público para seleção de operadores para o Serviço Especial de Seguro Postal (publicado no Diário Oficial da União do dia 09/05/2005), serviço que não chegou a ser implantado em razão de decisão do Tribunal de Contas da União ${ }^{97}$.

Conforme o Relatório Empresarial e Social da ECT de 2008, um dos objetivos da empresa é criar um diferencial competitivo. Nesse sentido, a estatal teria criado um serviço especializado (Remessa Local com Comprovação de Entrega), visando a atender remessa de citações, notificações e intimações dos Tribunais, do Ministério Público e das Procuradorias, bem como de IPTU, taxas, contribuições e notificações de débito das Prefeituras; e estaria também atuando fortemente no mercado eletrônico, criando soluções customizadas de logísticas. Estariam entre os seus clientes grandes empresas como a Nokia, LG, Sony e Motorola.

O relatório ainda veicula estratégias de negócio da empresa, entre as quais estão a ampliação do mercado internacional, a melhoria da capacitação da empresa para lidar com os desafios e a complexidade da gestão dos negócios postais oriundos de novas tecnologias de comunicação, como o comércio pelo celular, e-mail, SMS, e o desenvolvimento mais significativo do setor de telecomunicações, a exemplo do telefone on-line e VoIP.

\footnotetext{
${ }^{97}$ Com base na decisão do TCU (Acórdão n. ${ }^{\circ}$ 2356/2007 - TCU - Plenário) foi editada a portaria n. ${ }^{\circ}$ 694, de 13 de dezembro de 2007, tornando sem efeito a portaria n. ${ }^{\circ}$ 2.589/02, que havia instituído o Seguro Postal. Nessa decisão, embora o TCU tenha reconhecido que "atividades afins" (que podem ser exploradas pela ECT) são um conceito jurídico indeterminado, entendeu necessário diferenciar adequação da estrutura (se a infraestrutura da ECT é ou não adequada à prestação de serviços) de afinidade do serviço (se haveria ou não afinidade entre os serviços postais e aqueles que se pretendia atribuir à ECT). No caso do seguro postal, embora se tenha entendido que a infraestrutura da ECT é adequada à prestação de serviços (assim como seria adequada a qualquer atividade que demandasse uma larga rede de distribuição e de pontos-de-venda), concluiu-se que não havia “.... semelhança ou afinidade entre os serviços postais e a venda de seguros, planos de previdência e títulos de capitalização".
} 
Os Correios têm até uma Universidade Corporativa, através da qual são oferecidos cursos de formação para o desempenho de atividades inerentes a cargos, desenvolvimento de gestores e de capacitação técnica. Segundo o relatório Balanço Social dos Correios 2005, a Universidade tem sede em Brasília e representação em todo o país, incluindo cinco Centros de Educação. Conforme o relatório, seu objetivo é “...construir a ponte entre a competência e as estratégias de negócios da empresa" $"$.

Além disso, de acordo com esse relatório, os Correios oferecem também plano de saúde, contando com uma rede credenciada de aproximadamente 24 mil prestadores de serviços e 66 ambulatórios próprios, para oferecer assistência médica, hospitalar e odontológica a cerca de 354 mil beneficiários, entre empregados, dependentes, aposentados e colaboradores.

Diante desse mapeamento dos serviços prestados como postais, tem-se claramente que eles vão muito além da prestação de serviços tradicionais de carta e telegrama. A existência de um leque bastante abrangente de produtos e serviços, alguns propriamente postais (os serviços mais tradicionais) e alguns ancilares (agregados aos serviços postais tradicionais, mas que utilizam a rede do setor, como serviços bancários), torna possível afirmar que atualmente existe uma verdadeira "rede postal".

Conforme entrevista realizada no Ministério das Comunicações, a grande maioria dos objetos postais é postada por pessoas jurídicas (algo em torno de 92, 93\%), enquanto que apenas cerca de 7 ou $8 \%$ são postados por pessoas físicas. Em termos operacionais, conforme o Ministério, isso significa que o mercado de correspondências atualmente se volta em maior medida para a comunicação comercial, como forma de relacionamento entre empresários e seus clientes (marketing direto, através de malas diretas, por exemplo).

\footnotetext{
${ }^{98}$ O site da Universidade Corporativa dos Correios é <http://www.correios.com.br/universidade/default.cfm>. No site há poucas informações sobre os cursos oferecidos e sobre a "Universidade”. Segundo o relatório "Balanço Social dos Correios 2005”, “...em 2005, foram iniciadas duas turmas do Curso de Administração Postal para 73 alunos e três turmas de MBA com a participação de 121 empregados. Foram concedidas 1.193 bolsas de estudo para graduação, pós-graduação e idiomas. Para a formação e capacitação de técnicos operacionais, técnicos de atendimento e vendas, supervisores e coordenadores foram desenvolvidos cursos com a participação de 650 empregados".
} 
Neste sentido, segundo o Ministério, embora em razão das características do Brasil a carta ainda hoje tenha uma função importante, há uma tendência de que o tráfego de cartas caminhe para uma estabilização e posterior declínio, migrando para meios eletrônicos, assim como para transporte de valores. Mesmo as correspondências em geral, também financeiras (como contas de água, luz, fatura de cartão) tendem a ser substituídas por novas formas de comunicação eletrônica.

Em tal cenário, claramente se nota da política voltada para a estatal a intenção de criar no mercado "novos espaços" para a ECT, adaptando-a a uma nova realidade. Paralelamente ao declínio de preocupação que se verifica no âmbito da estatal com a entrega de cartas (em sentido estrito), assiste-se a um maior investimento não apenas em operações de impressos (que fazem parte de um mercado editorial significativo), de encomendas (que tem sofrido grande impacto devido ao comércio eletrônico) e de marketing direto (que são as propagandas; segundo os franqueados, a maior força da ECT para fazer frente à concorrência), como também em serviços financeiros. Quanto a estes, vêm crescendo não apenas os investimentos com correspondências financeiras, como contas de água, luz, fatura de cartão de crédito, que num médio e longo prazo tendem a sofrer um declínio pela profusão de transferências eletrônicas (associada à tendência atual da substituição dos papéis por novas formas de comunicação eletrônica), como também com outras transações bancárias feitas no banco postal.

Alinhada a essa preocupação institucional com a prestação de serviços financeiros pela ECT e de outros serviços lucrativos, está a edição da medida provisória n. ${ }^{o}$ 532/11, convertida na lei n. ${ }^{\circ} 12.490 / 11$, que expressamente confere à estatal a possibilidade de explorar os serviços financeiros, de logística integrada e postais eletrônicos. E não apenas isso. Como visto anteriormente, com o objetivo de autorizar a prestação dos "novos negócios" pela estatal, a MP possibilitou sua operação no exterior, o oferecimento de serviços de telefonia (com perspectivas de ser uma operadora móvel virtual), a utilização de uma frota de aviões própria ou a participação minoritária em outra frota já existente, e que se associe a outras empresas e negócios.

Em grande medida o discurso sobre os "novos negócios" que lastreia a ampliação da abrangência dos serviços postais tem como ponto central a necessidade de garantir-se a sobrevivência do setor. Neste sentido foi a manifestação do ex-ministro das comunicações Hélio Costa no início do ano de 2010 segundo a qual a reformulação da ECT era necessária 
para a recuperação de clientes e aumento da receita porque, segundo o ex-ministro, “...senão estaremos fadados em dois anos a ser uma carga pesada para o governo" $"$.

Neste sentido também é a redação da própria exposição de motivos da MP n. ${ }^{\circ}$ 532/11, segundo a qual "Em um cenário mais dinâmico de negócios, para que a ECT prossiga em seu modelo de autossustentação econômica e financeira, oferecendo à sociedade e ao mercado serviços de qualidade, será necessário enfrentar também as limitações de gestão que têm impedido a Empresa de se desenvolver".

Não obstante, como assinalado no Capítulo 1, as políticas públicas do setor parecem estar sendo adotadas sem um planejamento adequado e consistente. Bem é verdade que grande parte das medidas que estão sendo implementadas lastreia-se em discussões ocorridas no âmbito do Ministério das Comunicações e da ECT. Neste sentido, inclusive, entre os anos de 2009 e 2010, o “Grupo de Trabalho Interministerial” (GTI) elaborou propostas que serviram de suporte para a tomada de uma decisão política - com a edição da MP - no que toca ao aprimoramento da gestão da ECT. Desconhece-se, no entanto, qualquer trabalho que tenha por objeto não apenas a ECT como o setor postal como um todo.

Ademais, as políticas para a estatal são questionáveis. É possível questionar-se, por exemplo, em que medida uma prestadora de serviços postais tem expertise para a prestação de atividades bancárias, ainda que básicas, e mesmo em que medida isso não se afasta em muito do foco da prestação de serviços postais. Qual é o alargamento que se pretende dar aos serviços postais? A ECT passará a ser um banco, uma seguradora? Uma operadora de telefone, dentro da conjuntura da MP? Em que medida a rede de atendimento do setor postal coaduna-se com a construção e operação do trem de alta velocidade? Quais são as metas, as prioridades da estatal e para o setor como um todo?

E, para além disso, qual é o regime jurídico a que se submeterão esses novos serviços? Será que se coaduna com o ordenamento jurídico brasileiro que essas novas atividades submetam-se ao mesmo regime jurídico que incide sobre a prestação de serviços de carta pela ECT que, por ter traços públicos, é em certa medida privilegiado? Por outro lado, nas áreas em que há competição, como lidar com o desafio de capacitar melhor a estatal para competir com as empresas privadas, para que possam disputar mercados em ${ }^{99}$ Cf. notícia "Modernização dos correios prevê agências no exterior". Ver também notícia "Um novo
correio?". 
igualdade de condições? Poderia ser previsto um regime licitatório mais flexível e menos rígido do que o previsto na lei n. ${ }^{\circ} 8.666 / 93$ ?

As políticas de gestão eminentemente empresariais voltadas à ECT (a própria estatal se refere ao seu objetivo de criar um "diferencial competitivo" no Relatório Empresarial e Social da ECT de 2008) pouco esclarecem a respeito dessas questões. Dada a abrangência e diversidade dos serviços e a agilidade com que mudanças têm sido implementadas no setor (diversos serviços foram criados e regulamentados por portarias e mais recentemente por medida provisória), verifica-se que há uma grande dificuldade de se delimitar o conteúdo dos serviços postais. E, sendo o regime jurídico de determinado setor da economia concebido considerando o núcleo material dos serviços que engloba, a imprecisão da delimitação do conteúdo dos serviços postais acaba por acarretar diretamente consequências negativas ao regime jurídico aplicável ao setor, como se verá adiante.

A partir desse cenário de abrangência e diversidade dos serviços prestados por operadoras postais e adotado o pressuposto segundo o qual é difícil se delimitar claramente o conteúdo dos serviços postais, é importante analisar o funcionamento do ciclo postal e buscar identificar o que os serviços têm em comum e o que eles têm de diferente.

\section{IV.3. Possibilidade de diferenciação da rede postal por fases do ciclo postal ou por serviços}

Do ponto de vista operacional e seguindo o que a legislação preconiza (especificamente o art. $7^{\circ}$ da lei n. ${ }^{\circ} 6.538 / 78^{100}$ ), a ECT se utiliza de quatro sub-redes do ciclo postal, quais sejam, recebimento, expedição, transporte e entrega de objetos postais. Essas sub-redes não foram definidas na legislação postal, mas da prática operacional do setor $^{101}$ pode-se vislumbrar as seguintes características de cada uma delas:

A sub-rede recebimento volta-se ao atendimento da população, através das agências de Correio próprias ou terceirizadas.

\footnotetext{
100 "Art. $7^{o}$ - Constitui serviço postal o recebimento, expedição, transporte e entrega de objetos de correspondência, valores e encomendas, conforme definido em regulamento".

${ }^{101}$ Cf. entrevista realizada no Ministério das Comunicações.
} 
A sub-rede expedição volta-se ao tratamento que será dado ao objeto postal, constituindo-se, pois, na parte industrial do ciclo postal, englobando atividades como a separação dos objetos postais, a triagem dos objetos de acordo com as direções para as quais serão transportados, a preparação de contêineres e assim por diante.

A sub-rede transporte relaciona-se aos meios de transporte a serem utilizados (aéreo, terrestre, aquático) e aos veículos correspondentes.

A sub-rede distribuição refere-se especificamente à entrega dos objetos postais, por intermédio dos carteiros.

O esquema abaixo representa o ciclo postal a partir do momento em que o objeto é postado em uma agência de Correio até ele ser enviado ao seu destino final:

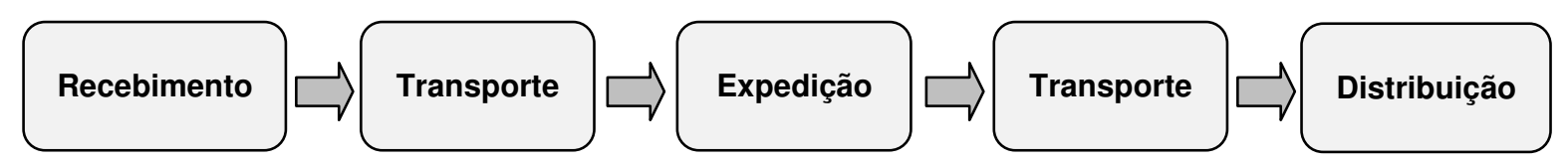

Regra geral, os objetos postados seguem esse ciclo postal integralmente. Alguns, entretanto, pela sua própria natureza, prescindem de passar por todas as etapas do ciclo, utilizando uma ou algumas sub-rede(s) individualmente. É o caso, por exemplo, dos serviços de inscrição para concurso público e do banco postal, que nascem e morrem nas agências, utilizando-se, portanto, de uma única sub-rede, a de recebimento. É o caso também das malas diretas domiciliares que, por serem propagandas não endereçadas, uma vez recebidas passam direto para a distribuição através dos carteiros, prescindindo das demais fases do ciclo.

Como em regra os objetos postais passam por todas as fases da cadeia e dado o fato de a rede do setor ser única, embora dividida em fases, na etapa final do ciclo, de distribuição, por exemplo, haverá nos caminhões dos Correios cartas, cartões-postais, encomendas, Sedex, impressos, objetos de logística como celulares, livros do MEC, ou seja, diferentes modalidades de objetos postais.

Essa configuração da cadeia e da rede do setor torna-se particularmente importante diante da possibilidade de incidências regulatórias distintas sobre etapas da cadeia de atividades econômicas (em sentido amplo), como aconteceu com a divisão da cadeia produtiva do setor de energia elétrica (produção, transmissão, distribuição e comercialização de energia), ou por modalidades de serviços, tal como ocorreu no setor de 
telecomunicações, em que a incidência regulatória recai de maneira distinta em vista das modalidades de serviços, se telefonia fixa ou móvel ${ }^{102}$.

No primeiro caso, em face de uma possível reestruturação do setor postal, pode-se cogitar da segregação da cadeia postal em vista dos segmentos que ela comporta (as subredes), quais sejam, recebimento, expedição, transporte e entrega de objetos postais. Neste caso, eventuais regras de competição seriam relacionadas às diferentes fases do fluxo postal, ainda que pudessem se relacionar também aos tipos de objetos postais (se eles têm as características de carta, encomenda, impresso etc.). É dizer, as regras se relacionariam a como e em que medida essas fases poderiam se sujeitar à exploração privada (com vínculo de outorga ou em regime de mercado, independentemente de qualquer vínculo), e como e em que medida estariam sujeitas à exploração pela ECT.

De certa forma, esta divisão por etapas ocorre hoje no setor em relação às franquias postais. Ainda que ao longo do tempo muitas tenham mudado de perfil, substancialmente as franquias apenas podem atuar na primeira fase do ciclo postal, o recebimento ${ }^{103}$. Uma vez postados os objetos nas agências franqueadas e observada a programação de transporte da ECT, a estatal é responsável por captar os objetos nas agências e transportá-los até o centro de tratamento (sub-rede expedição), ao qual converge o fluxo postal de todas as agências do Correio. Na prática esse transporte até a fase de expedição vem sendo feito também pelas agências franqueadas, que além de aguardarem as viaturas dos Correios, hoje também têm frota de veículos própria ${ }^{104}$.

\footnotetext{
102 Sobre a reformulação dos setores de energia elétrica e telecomunicações, ver Ana Maria de Oliveira Nusdeo, "Agências reguladoras e concorrência". In: SUNDFELD, Carlos Ari (coord.). Direito administrativo econômico, p. 159-189.

${ }^{103}$ É difícil precisar as áreas nas quais as franquias postais podem atuar. A informação de que essas agências só atuam na primeira fase do ciclo postal (captação) foi obtida junto ao Ministério das Comunicações. No entanto, conforme entrevista na ABRAPOST-SP, embora num primeiro momento tenha sido proibido às franqueadas exercerem a primeira fase do transporte (a coleta nas agências para as centrais de expedição), ao longo do tempo isso teve de ser autorizado pela ECT, bem como para as permissionárias do setor postal, as quais inicialmente também podiam atuar apenas na fase de captação. De acordo com a entrevista realizada na ABRAPOST-SP, nos novos contratos de franquia, o que eles consideram temerário, há proibições para as agências fazerem essa coleta. Por outro lado, segundo o Ministério, algumas franquias (não é algo generalizado no Brasil, relacionando-se a algumas agências maiores em São Paulo) passaram a operar uma fase de pré-postagem, que seria uma fase de produção do objeto, existente apenas em operações especiais montadas pela ECT para seus grandes clientes. Nestes casos, são montadas estações de trabalho e ECT/franqueadas entram em contato com as gráficas para que o material gráfico seja feito de acordo com especificações, e procede-se ao manuseio do material antes da postagem (dobra, envelopamento, ordenação, inserção em envelopes, inserção de etiquetas, trabalho com o mailing). Atualmente essa operação de prépostagem é vedada às agências franqueadas e às agências permissionárias.

${ }^{104}$ Conforme entrevista realizada na ABRAPOST-SP.
} 
Portanto, após a fase de recebimento (ou dessa primeira de transporte), é a ECT que opera todas as demais fases do ciclo postal, até que o objeto chegue ao seu destino final. Nesta linha, uma vez dividida a cadeia produtiva do setor postal, e consideradas as condições estruturais e tecnológicas do setor, as empresas privadas poderiam ser autorizadas tão somente a operar uma ou algumas das fases do ciclo, após o que passariam a se utilizar da rede da ECT, trabalhando de maneira integrada, conforme condições estabelecidas, com a rede que a estatal opera.

Apesar dessa experiência das agências franqueadas, dada a forma como tem ocorrido a acomodação de empresas no setor postal, a organização do regime semicompetitivo no setor tem mais características de uma divisão por serviços, a despeito de ainda ser necessário estabelecer mais claramente a organização desse regime semicompetitivo ou competitivo, se assim se entender adequado, e especialmente quais serviços postais podem comportar prestação segundo parâmetros de mercado (em vista de suas condições estruturais e tecnológicas) e em qual extensão.

Neste sentido, como será aprofundado no capítulo subsequente, tem-se firmado entendimento segundo o qual encomendas e impressos são objetos postais competitivos, enquanto que estariam fora do livre mercado serviços como cartas ${ }^{105}$. Essa divisão lastreiase inclusive no fato de o "monopólio" postal conferido à ECT estar, inclusive na legislação atual, delimitado conforme os serviços que a estatal presta. Mesmo no caso das franquias postais, a atuação dos franqueados sofre limitações em relação aos serviços que podem $\operatorname{prestar}^{106}$. É dizer, não são todos os serviços que a ECT oferece à população que os franqueados podem operar, o que é definido nos contratos celebrados com a estatal e pela legislação infralegal.

\footnotetext{
${ }^{105}$ Em linhas gerais, este foi o entendimento adotado na ADPF n. ${ }^{\circ}$ 46-7/DF.

${ }^{106} \mathrm{Nem}$ todos os contratos podem ser operados pela rede franqueada (e pelos permissionários), o que é determinado pela legislação infralegal e contrato. Em certa medida a estatal considera que as decisões de incluir ou excluir serviços no leque de operações das agências franqueadas estão na margem de discricionariedade que ela exerce sobre a regulação da atividade. De acordo com as entrevistas no Ministério e na ABRAPOST-SP, as atuais franqueadas e permissionárias não prestam serviços do banco postal (com os novos contratos passariam a prestá-los) e são proibidas de praticar as operações de pré-postagem. Os novos contratos ainda apresentariam vedações à exploração de serviços de marketing direto, o que segundo a ABRAPOST-SP constituiria um problema, uma vez que essa atividade representa em geral metade do volume de depósitos (faturamento) das agências franqueadas e a forma delas fazerem frente à atuação da concorrência.
} 
Adotada essa divisão por serviços, é importante que se defina claramente o que é uma carta, o que é uma encomenda, o que é um impresso, por exemplo, para que se evitem problemas que hoje acometem o setor, como, e especialmente, a existência de certa insegurança jurídica sobre quais serviços as empresas privadas de distribuição podem prestar. Em grande medida este problema da insuficiência da definição é efeito jurídico oriundo do alargamento da abrangência dos serviços e da complexidade que eles vêm assumindo ao longo dos últimos anos e da insuficiência de clareza quanto à adoção ou não do regime de livre mercado, ao menos parcialmente.

Nesse caso da separação por serviços, o fato de a rede ser única e, pois, um mesmo caminhão transportar os mais variados objetos postais, pode acarretar e tem gerado problemas para diferenciarem-se os regimes jurídicos incidentes sobre cada serviço. É dizer, a rede do setor precisará ser diferenciada, conforme se tenha objetos postais prestados no regime público ou conforme se tenha objetos postais prestados no regime privado.

Isso porque, conforme se verá no Capítulo 3, se os objetos postais transportados pela ECT se submeterem ao regime de serviço público, à estatal serão aplicáveis os privilégios da imunidade tributária recíproca e da impenhorabilidade de bens, o que não acontece quando ela presta atividades em regime de mercado, em competição com os demais prestadores. De maneira assemelhada os veículos da ECT (bem assim os utilizados pelas franquias postais) não se submetem a rodízio, quaisquer que sejam os objetos que estejam transportando, enquanto que os veículos das prestadoras privadas têm de parar sua frota de veículos conforme os dias de rodízio, submetendo-se às sanções pertinentes ${ }^{107}$.

Para que se evitem problemas práticos hoje existentes ${ }^{108}$ de como se tributar os objetos transportados pela ECT (se devem ser tributados e mais precisamente quais devem ser tributados) e de saber se os veículos da ECT devem se submeter a rodízio e quais objetos é lícito que a ECT transporte dispensando-se o rodízio, deve-se lidar com o fato de a rede postal ser única.

\footnotetext{
${ }^{107}$ Cf. entrevista realizada na ABRAED.

108 Conforme se verifica da análise de jurisprudência objeto do Capítulo 3. Em linha assemelhada, em entrevista realizada junto ao Ministério das Comunicações, o então subsecretário dos serviços postais contou que é comum que os caminhões da ECT sejam parados em barreiras, nas quais se questiona se os serviços foram tributados.
} 
É dizer, operacionalmente o fato de a rede postal ser única constitui-se em um problema, gerando a necessidade de ou se duplicar a rede, o que pelo custo que demanda pode ser inviável ou desnecessário, ou se estabelecer, especialmente em relação ao transporte, horários do fluxo postal em regime público e horários em regime privado, ou ainda estruturas e frotas diferenciadas por serviços e assim por diante. Pode-se cogitar ainda do estabelecimento de regras de compartilhamento de redes e de proteção à competição. Ou seja, devem ser criados mecanismos, que não necessariamente passem por soluções estruturais (ou mesmo pelas soluções cogitadas), que possibilitem à estatal competir em determinados serviços em igualdade com as demais prestadoras privadas, sendo-lhe reservado regime específico e mais protetivo na medida do necessário pelos serviços de caráter público que presta à coletividade.

Diante disso, procurar-se-á no tópico seguinte propor uma divisão dos serviços postais tendo em vista as diferenças que apresentam em relação à sua essencialidade para a coletividade, seu conteúdo econômico e sujeição à competição.

\section{IV.4. Diversidade de serviços postais em relação à essencialidade, conteúdo econômico e competição}

Adotado o pressuposto segundo o qual a acomodação de empresas no setor postal tem se organizado baseada nos serviços ofertados, e dada a abrangência e diversidade do conteúdo das atividades prestadas como postais por operadoras do setor, passa a ser relevante identificar o quanto os serviços são essenciais para a coletividade, o quanto são relevantes do ponto de vista econômico e o quanto são competitivos. Isso porque há efeitos jurídicos que derivam dessa ampliação e diversidade dos serviços prestados como postais especialmente relacionados ao regime jurídico ao qual os serviços se submeterão, que pode ser diferenciado.

Os serviços postais diferem em relação à sua essencialidade social para a coletividade. É possível notar que a rede postal engloba serviços que são mais relevantes do ponto de vista social e outros que são menos. Do mesmo modo, tendo em vista que a rede de infraestrutura da estatal é muitas vezes utilizada para atividades que não se relacionam com a transmissão de um fluxo de informações no território nacional e mesmo internacional, é possível diferenciar os serviços pelos diferentes graus de importância que eles têm em relação à raiz da atividade postal, a integração da comunicação nacional. 
O fato de ser dada à população, indistintamente, a possibilidade de postar uma carta cujo endereçamento seja manuscrito contendo a indicação "carta social”, e que tenha limite máximo de peso igual a 10 gramas, pelo preço de um centavo ${ }^{109}$, traz em si uma conotação mais social, especialmente quando este serviço é comparado a outros também prestados pela ECT, como o serviço de logística dos Correios oferecido para a Sony. A entrega de cartas como um todo, a despeito de serem ou não sociais, de maneira geral tem uma conotação social que não é comparável, por exemplo, às malas diretas que visam a proporcionar comunicação entre empresas e seus clientes. Por outro lado também serviços como banco postal, universidade corporativa, pagamento de aposentados do INSS, pagamento de contas, por exemplo, não são tão essenciais do ponto de vista da integração da comunicação nacional.

Diretamente relacionada a esta questão da essencialidade, é possível diferenciar os serviços pelos seus distintos conteúdos econômicos, relacionados à possibilidade de geração de lucros. A entrega de documentos mercantis em geral, atividades como banco postal, seguro postal (ainda não implementado), exporta fácil e importa fácil, por exemplo, denotam um viés mais empresarial da ECT do que os serviços convencionais. Podem ter um valor social agregado, como de fato têm (a prestação de serviços bancários básicos às populações carentes, no caso do banco postal, e a exportação de produtos de pequenas empresas que não tinham acesso ao mercado externo e que através dos correios, de maneira simplificada, passam a ter), mas seu objeto parece ser mais voltado à lucratividade da ECT.

De maneira semelhante, as medidas recentemente instituídas pela MP n. ${ }^{\circ}$ 532/11 visam a proporcionar uma maior lucratividade para a empresa, voltando-se aos serviços financeiros, de logística integrada, postais eletrônicos, à sua operação no exterior, ao oferecimento de serviços de telefonia, e à sua associação a outras empresas e negócios, a partir do estabelecimento de parcerias comerciais que agreguem valor à sua marca e à sua rede de atendimento.

${ }^{109}$ Portaria n. $^{\text {o } 245}$, de 09 de outubro de 1995 c/c portaria n. ${ }^{\circ} 1.061$, de 29 de dezembro de 2009. 
Não se está com isso atribuindo um juízo de valor negativo às diferentes atividades englobadas como serviços postais. Primeiro porque o próprio figurino de empresa pública confere à ECT não apenas a perseguição de uma missão pública (concretizada, por exemplo, através das políticas sociais da empresa vistas acima), mas também um viés empresarial $^{110}$ (as estatais se organizam sob a forma empresarial, tanto assim que têm personalidade jurídica de direito privado). Nesse sentido, a própria escolha política do Estado de atribuir à empresa estatal a prestação do serviço postal deixa claro que a prestação do serviço tem uma natureza econômica.

Segundo porque, especialmente no setor postal, que tem perdido espaço para as novas tecnologias de informação, o aumento da complexidade dos serviços com a criação de uma verdadeira rede postal é forma de garantir a sobrevivência do setor. Terceiro porque a utilização da infraestrutura da rede de atendimento da ECT (de grande capilaridade) para a prestação de serviços não postais pode ser uma boa forma de se alcançar pessoas e localidades que não são atingíveis por outros serviços de interesse geral. É o caso do banco postal, quando prestado no âmbito dos municípios desassistidos de atendimento bancário básico, e do uso da infraestrutura da ECT para entrega de livros didáticos e emissão de CPF, por exemplo.

Os serviços postais diferem ainda em relação à possibilidade de se sujeitarem ou não a algum grau de competição dadas as suas condições estruturais e tecnológicas (um monopólio natural, por exemplo, por suas próprias características, impede que algumas atividades se submetam à concorrência) e à disciplina jurídica que se pretende dar ao setor, o que em grande medida relaciona-se ao modelo de Estado existente ou que se pretende adotar, se mais ou menos intervencionista.

Diante disso, é importante analisar se as atividades postais são monopólios naturais, de acordo com a conceituação econômica. Por essa conceituação, de acordo com N. Gregory Mankiw, um monopólio natural surge “...quando uma só empresa consegue ofertar um bem ou serviço a um mercado inteiro a um custo menor do que duas ou mais empresas" $" 111$.

\footnotetext{
${ }^{110}$ Alguns autores, como Gaspar Ariño Ortiz, veem na própria designação empresa pública uma contradição inerente: como pode ser ao mesmo tempo empresa e pública?, questiona o jurista ("La empresa pública: teoría y práctica. Líneas de reforma". In: Principios de derecho público econômico, p. 397). A imagem contraditória trazida pelo autor parece ser capaz de expressar a combinação de dois fatores distintos, que por vezes parecem ser inconciliáveis, a utilização da forma empresarial para a realização de fins públicos.

${ }^{111}$ N. Gregory Mankiw, Introdução à economia, p. 301.
} 
De acordo com Fábio Nusdeo ${ }^{112}$, são as próprias condições estruturais e tecnológicas de alguns setores, cujos custos de produção fixos (como maquinário, instalações e base territorial) são desproporcionalmente elevados em relação aos custos variáveis (matérias-primas, energia e mão de obra), que impedem sua organização em regime de concorrência. Em suas palavras, "Seus custos [de uma única empresa] em regime de monopólio são assim inferiores àqueles em que incorreriam várias empresas, individualmente, num mercado competitivo, pois a alta proporção dos custos fixos exige a produção em larga escala, e o mercado somente absorve a oferta de uma empresa naquele nível de produção" ${ }^{" 113}$.

Significa dizer, assim, que as empresas potencialmente entrantes num mercado, sabendo que não poderão atingir os mesmos custos baixos do monopolista (que normalmente tem a propriedade de um recurso-chave), optam por não fazê-lo, porque após o ingresso cada uma teria uma fatia menor do mercado ${ }^{114}$ e não produziriam em escala viável.

Estabelecidos os conceitos, há suporte para se afirmar que no passado é possível que o setor postal (ou ao menos algumas etapas da cadeia) tivesse características de monopólio natural (um monopólio natural da União), tendo passado ao longo do tempo a comportar a acomodação de um maior número de empresas que produzem em escala viável, com algum grau de concorrência com a $\mathrm{ECT}^{115}$. É dizer, seu lucro atraiu novas empresas para o mercado, tornando-o mais competitivo, chegando mesmo ao ponto de em certa medida elas ferirem e colocarem em risco o "monopólio" legal (jurídico) conferido à estatal.

\footnotetext{
${ }^{112}$ Fábio Nusdeo, Curso de economia: introdução ao direito econômico, p. 274.

${ }^{113}$ Fábio Nusdeo, Curso de economia: introdução ao direito econômico, p. 274.

${ }^{114}$ Cf. N. Gregory Mankiw, Introdução à economia, p. 302.

115 Fábio Nusdeo não trata especificamente do setor postal, mas afirma que mais recentemente diversos setores que no passado eram tidos como monopólios naturais passaram a comportar algum grau de concorrência, tendo sido submetidos a uma meticulosa regulação estatal, inclusive com a criação de agências reguladoras especiais (Agência Nacional de Energia Elétrica - ANEEL, Agência Nacional de Telecomunicações - ANATEL, Agência Nacional do Petróleo - ANP). Curso de economia: introdução ao direito econômico, p. 275.
} 
A partir da realidade em alguma medida já concorrencial do setor postal (ou ao menos de algumas das etapas de sua cadeia, nas quais atuam variadas empresas produzindo em escala viável), verifica-se que ele pode funcionar nestas condições, restando apenas estabelecer mais claramente a organização do regime competitivo ou semicompetitivo, e especialmente quais segmentos da cadeia produtiva do setor postal podem se submeter a parâmetros de mercado (em vista de suas condições estruturais e tecnológicas) e em qual extensão, observando-se a intensidade de intervenção estatal que se pretende nele adotar, e o modelo de Estado que a esta decisão é subjacente.

Tendo em vista os diferentes graus de essencialidade dos serviços, seu conteúdo econômico e a possibilidade de serem ou não prestados em regime de competição e tomando por base o funcionamento do setor (daí a importância de se diferenciar a rede postal por fases do ciclo postal ou por serviços), passa a ser possível discutir e analisar a possibilidade de se identificar o regime jurídico aplicável à estatal e aos demais prestadores do setor a partir do caso concreto, diante da relevância do serviço envolvido com vistas a atingir finalidades públicas.

Nesse caso, o regime jurídico da ECT e dos demais prestadores do setor passaria a ser modulado, conforme variarem as atividades desenvolvidas (tendo em vista sua essencialidade para a coletividade, seu conteúdo econômico e o fato de serem ou não prestadas em regime de competição), e de acordo com a necessidade de o Estado regulálas. Essa questão será retomada no capítulo seguinte, especificamente no item V.4. Antes, porém, necessário analisar as principais discussões que se tem hoje na doutrina e especialmente na jurisprudência relacionadas ao regime jurídico do setor postal. 


\section{CAPÍTULO 3 - REGIME JURÍDICO DOS SERVIÇOS POSTAIS}

\section{V.1. O setor postal frente à avaliação crítica sobre o regime jurídico dos serviços públicos}

\section{V.1.1. O problema central da definição de serviço público}

A presente dissertação não se destina a teorizar sobre serviço público, tampouco tem por objetivo rever as razões que têm levado à transformação dos serviços públicos. $\mathrm{O}$ objetivo que se busca inicialmente neste Capítulo 3 é investigar o que se considera "serviço público" em geral, dado que a discussão em torno da natureza jurídica do serviço postal depende em grande medida do debate mais amplo acerca dessa questão.

Para tanto, num primeiro momento, procurar-se-á tratar da tradicional separação entre o campo próprio de atuação do Estado e o campo de atuação do setor privado, que parte da dicotomia serviços públicos versus atividades econômicas. A despeito de a presente pesquisa concluir que em grande medida esta dicotomia é insuficiente, considerase importante analisar suas principais notas características em vista de sua larga utilização na doutrina e em especial na jurisprudência.

Seguindo essa repartição, o campo dos serviços públicos não é livremente explorado por particulares, mas estes podem prestar os serviços assim considerados se firmarem com o poder público um contrato de delegação (concessão ou permissão de serviços públicos), nos termos do que dispõe o art. 175 da Constituição ${ }^{116}$. Segundo alguns doutrinadores como Celso Antônio Bandeira de Mello, há serviços públicos que não podem ser prestados por particulares nem mesmo através da celebração de contratos de delegação, uma vez que seriam privativos do Estado, de prestação obrigatória e exclusiva deste $^{117}$.

\footnotetext{
116 "Art. 175. Incumbe ao Poder Público, na forma da lei, diretamente ou sob regime de concessão ou permissão, sempre através de licitação, a prestação de serviços públicos".

${ }^{117}$ Cf. Celso Antônio Bandeira de Mello, Curso de direito administrativo, p. 645. Vera Monteiro, ao tratar da inexistência de garantia de que uma atividade seja necessariamente delegável por ser serviço público, afirma que "[h]á determinados serviços que somente o Estado pode executar diretamente, porque são inerentes à sua soberania, à defesa nacional, à segurança e à saúde pública. São atividades cuja execução envolve atos de autoridade e, com relação a esses atos, não é possível cogitar-se de delegação" (Concessão, p. 123).
} 
O campo das atividades econômicas ${ }^{118}$, por sua vez, é em regra explorado pelo setor privado, podendo o Estado atuar nesse campo em caráter excepcional, (i) quando a exploração direta pelo Estado for necessária aos imperativos da segurança nacional ou a relevante interesse coletivo, conforme definidos em lei (art. 173 da Constituição), e (ii) nos casos previstos na Constituição, ou seja, nas hipóteses do art. 177 e do art. 21, XXIII (monopólios estatais previstos no texto constitucional) ${ }^{119}$.

Segundo essa corrente doutrinária que reparte os serviços públicos das atividades econômicas, a grande razão de ser dessa distinção reside em identificar o regime jurídico aplicável a um determinado serviço ${ }^{120}$. Nesse sentido, da definição da natureza jurídica de um determinado serviço advêm consequências relacionadas ao regime de sua exploração. Se certa atividade é tida como um serviço público, sobre ela recairá um regime de direito público. Se for tida como atividade econômica, lhe será aplicável um regime de direito

118 Adotada a classificação de Eros Grau, bastante difundida, está-se aqui se referindo a atividades econômicas em sentido estrito. O jurista distingue "atividades econômicas em sentido amplo" (área de atuação estatal) das espécies "atividade econômica em sentido estrito" (área de intervenção estatal) e "serviço público". Segundo o autor, a Constituição teria se utilizado da expressão "atividade econômica" ora para se referir à atividade econômica em sentido estrito, ora para se referir à atividade econômica em sentido amplo. Quando a Constituição fala no caput do art. 174 que "Como agente normativo e regulador da atividade econômica, o Estado exercerá, na forma da lei, as funções de fiscalização, incentivo e planejamento, sendo este determinante para o setor público e indicativo para o setor privado" (grifo meu) quer com isto fazer referência à atividade econômica em sentido amplo (e ao papel de Estado regulador). Da mesma forma a Constituição estaria se referindo à atividade econômica em sentido amplo quando prevê que "A ordem econômica, fundada na valorização do trabalho humano e na livre-iniciativa, tem por fim assegurar a todos existência digna, conforme os ditames da justiça social..." (art. 170, caput) e que "É assegurado a todos o livre exercício de qualquer atividade econômica, independentemente de autorização de órgãos públicos, salvo nos casos previstos em lei" (art. 170, parágrafo único, grifo meu), uma vez que toda atividade econômica (seja ela serviço público ou atividade econômica em sentido estrito) deve ser fundada na valorização do trabalho humano e na livre-iniciativa. Quando a Constituição diz no caput do art. 173 "Ressalvados os casos previstos nesta Constituição, a exploração direta de atividade econômica pelo Estado só será permitida quando necessária aos imperativos de segurança nacional ou a relevante interesse coletivo, conforme definidos em lei" (grifo meu), atividade econômica estaria se referindo às hipóteses nas quais é permitida a atuação do Estado no campo próprio ao setor privado (diria respeito às atividades econômicas em sentido estrito), pois o Estado-empresário deve ser considerado exceção. Sua atuação nesse campo estaria adstrita às hipóteses de imperativos de segurança nacional ou relevante interesse coletivo (art. 173) e nos casos de monopólio previstos na Constituição (art. 177 e art. 21, XXIII). Cf. A ordem econômica na Constituição de 1988, p. 105 e ss.

${ }^{119}$ Cf. Eros Grau, A ordem econômica na Constituição de 1988, p. 127.

${ }^{120}$ Cf. Fernando Herren Aguillar, Controle social de serviços públicos, p. 149. Em suas palavras, “...podemos dizer que o regime jurídico é que determina fundamentalmente tratar-se de serviço público ou atividade econômica em sentido estrito". Nesse sentido, também Celso Antônio Bandeira de Mello, Curso de direito administrativo, p. 637. Ver também Fernando Dias Menezes de Almeida: “... a causa principal que justifica a distinção entre serviços públicos e atividades econômicas diz com os regimes jurídicos que lhes são reservados pela Constituição..." ("Aspectos constitucionais da concessão de serviços públicos". In: MEDAUAR, Odete (coord.). Concessão de serviço público, p. 31). 
privado. Em termos práticos, atividades consideradas serviços públicos só poderão ser desempenhadas por particulares mediante concessão ou permissão, contratos celebrados sempre mediante prévio procedimento licitatório. Caso contrário, como nota Fernando Herren Aguillar, essas atividades estarão em situação irregular ${ }^{121}$.

Porém, a despeito de a distinção serviço público versus atividade econômica ser tradicional, nem sempre é fácil na prática dizer se uma determinada atividade caracterizase como serviço público ou como atividade econômica, o que denota a importância de se repensar a utilidade dessa distinção. E mais do que isso: um mesmo serviço pode ser prestado tanto no regime público quanto no privado, desde que se estabeleçam claramente as regras do jogo para o convívio entre os diferentes prestadores, submetidos à variação de regimes, ou seja, a distintas incidências regulatórias, fenômeno que se tem denominado assimetria regulatória ${ }^{122}$.

Essa possibilidade respalda-se no entendimento segundo o qual é possível introduzir competição mesmo em atividades consideradas serviços públicos, como tem ocorrido hoje em setores como o de telecomunicações (o serviço de telefonia fixo é explorado por concessionários, em regime público, e autorizatários, em regime privado, submetidos a incidências regulatórias distintas) ${ }^{123}$. Por detrás desse entendimento, como observa Vera Monteiro, está a visão segundo a qual a concepção de serviço público engloba “...atividades relevantes e de interesse público, independentemente do regime por meio do qual ele é prestado" ". Com isso, poderiam ser considerados "serviços públicos" mesmo os serviços prestados em regime privado que não se sujeitassem às obrigações típicas do regime público.

${ }^{121}$ Cf. Fernando Herren Aguillar, Controle social de serviços públicos, p. 138.

${ }^{122}$ A respeito do tema, ver Floriano de Azevedo Marques Neto, "A nova regulação dos serviços públicos", Revista de Direito Administrativo, v. 228, p. 23. Ver também Carlos Ari Sundfeld, "Meu depoimento e avaliação sobre a lei geral de telecomunicações", Revista de Direito de Informática e Telecomunicações, n. ${ }^{\circ}$ 2 .

${ }^{123}$ Sobre o tema, Floriano de Azevedo Marques Neto: “...inexistindo na Constituição a previsão de exclusividade na prestação do serviço [postal], a lei poderá estabelecer os contornos da competição no setor..." ("Reestruturação do setor postal brasileiro", Revista Trimestral de Direito Público, v. 19, p. 169).

${ }^{124}$ Vera Monteiro, Concessão, p. 86. 
Essa possibilidade de adoção de soluções híbridas, de modulação de regimes aplicáveis acaba inclusive por colocar em xeque a validade de uma apartação estanque entre serviços públicos e atividades econômicas. Nesse sentido, Carlos Ari Sundfeld afirma que a razão principal de a noção de serviço público não ser mais útil, ao menos da forma como era no passado, relaciona-se à dificuldade de se "...identificar o caráter público ou privado do serviço em causa, que teria o mágico condão de determinar a aplicabilidade de um regime jurídico geral" ${ }^{\text {"125 }}$. A partir disso, o autor entende que o enfoque da discussão deve se alterar: deve-se deixar de lado a discussão sobre o caráter público ou privado de um determinado serviço para se buscar identificar como o serviço é regulado nos mais diversos aspectos.

\section{V.1.2. Pluralidade de regimes jurídicos dos serviços públicos}

Diante disso, é possível afirmar que inexiste um regime jurídico único e geral para os serviços públicos e tampouco para as atividades econômicas. Será o arranjo contratual moldado para o caso concreto, conforme as peculiaridades do serviço prestado, o que tiver sido definido no ato de outorga e a legislação aplicável, que ditará as sujeições a que o particular terá de se submeter, relacionadas, por exemplo, à definição dos direitos e obrigações das partes, aos critérios de cobrança pelos serviços, metas e investimentos que serão exigidos, a como se dará a reversão dos bens, prazo de exploração, critérios para extinção do vínculo, hipóteses de extinção antecipada, critérios de reequilíbrio econômicofinanceiro, fiscalização, forma de solução de conflitos, penalidades aplicáveis, repartição de riscos, compartilhamento de ganhos econômicos, fixação de obrigações de universalização, dentre outras ${ }^{126}$.

\footnotetext{
${ }^{125}$ Carlos Ari Sundfeld, "Introdução às agências reguladoras”. In: SUNDFELD, Carlos Ari (coord.). Direito administrativo econômico, p. 33.

126 Trata-se de rol de condicionamentos meramente exemplificativo. Como bem acentua Vera Monteiro, atualmente é importante que as concessões, permissões e autorizações sejam vistas como “....instrumentos de regulação, os quais podem assumir múltiplos formatos, conforme a conveniência e as peculiaridades de um dado setor econômico e das partes envolvidas" (Concessão, p. 94). Nesse sentido, como afirma a autora, " $O$ contrato poderá lançar mão dos variados mecanismos previstos na legislação para compor o melhor arranjo contratual diante de um caso concreto" (Concessão, p. 185). A esse respeito ver também p. 175.
} 
Mesmo as atividades livres aos particulares, ainda que sujeitas à dinâmica do livre mercado, poderiam por suas características ter de se submeter à autorização, como ato de polícia administrativa num setor regulado da economia. Mesmo nesse caso, seria possível que o poder público induzisse comportamentos privados, inclusive através do estabelecimento de relações contratuais (como uma concessão), com vistas a atingir certas finalidades públicas ${ }^{127}$.

A partir dessa constatação de que há uma pluralidade de regimes jurídicos, e tomando por base o setor postal, destaca-se que é possível que, mediante lei, se adote para o setor essa pluralidade de regimes jurídicos. Estabelecidas claramente as regras do jogo para o convívio entre os diferentes prestadores, os serviços postais poderiam se submeter a incidências regulatórias distintas. Especificamente em relação ao setor postal, essa análise da pluralidade de regimes jurídicos em face da heterogeneidade do conteúdo dos serviços, objeto do Capítulo 2, será desenvolvida em item próprio desta dissertação (item V.4).

\section{V.2. Natureza jurídica dos serviços postais e a validação pelo STF de um regime jurídico protetivo à ECT}

\section{V.2.1. Panorama do serviço postal na Constituição Federal de 1988 e na legislação infraconstitucional}

\section{V.2.1.1. Alcance do art. 21, X da Constituição}

A prestação do serviço diretamente pelo Estado respalda-se juridicamente na competência atribuída à União para manter o serviço postal. Na Constituição de 1988 essa competência vem arrolada no art. $21, \mathrm{X}^{128}$, mas a mesma redação é encontrada nas Constituições de 1934 (art. 5º, VII), de 1937 (art. 15, VI), de 1946 (art. 5, XI), de 1967

\footnotetext{
${ }^{127}$ Vera Monteiro, Concessão, p. 124. Diz a autora: “A hipótese aqui tratada não é a do Estado regulador da economia, mas a do Estado indutor de comportamentos privados por meio do oferecimento de uma relação contratual. É o que acontece com os serviços de saúde, educação, assistência social e previdência, cuja oportunidade de exploração pela iniciativa privada independe de ato formal de delegação, haja vista que o direito de exploração já é assegurado pela Constituição, mas que pode ser objeto de uma relação contratual por meio da qual o privado atue em nome do Estado". Nesse caso estaríamos diante de um "...modelo de delegação de 'atividade econômica'..." (Concessão, p. 125).

128 “Art. 21. Compete à União: X - manter o serviço postal e o correio aéreo nacional”.
} 
(art. 8, XI) e na Emenda Constitucional n. ${ }^{\circ}$ 1, de 1969 (art. 8º XII). A Constituição limitou-se a atribuir competência à União para manter o serviço e para privativamente legislar sobre serviço postal (art. 22, $\left.\mathrm{V}^{129}\right)^{130}$.

Conferiu, assim, a esse ente federativo, o dever de explorar tal atividade e o poder de regulá-la. Silenciou, no entanto, sobre a forma de prestação do serviço. Nesse sentido, seu texto nada previu a respeito da possibilidade de os serviços serem prestados por particulares, seja através de contratos de delegação de serviços públicos (concessão, permissão e autorização), seja em regime privado (próprio às atividades econômicas exploradas livremente por particulares). Da mesma forma, não há no texto constitucional nenhuma referência à possibilidade ou obrigatoriedade de a União explorar o serviço em regime de exclusividade, interditando eventual prestação por particulares.

Com isso, pretende-se chamar atenção para o fato de que não se extrai claramente do texto constitucional a natureza jurídica do serviço postal e o regime jurídico que lhe é aplicável. Trata-se de conclusão importante, uma vez que, admitindo-se que a Constituição não restringiu as opções do legislador, a legislação infraconstitucional tem ampla margem para a normatização do setor. Inclusive, novas regras para o setor podem ser fixadas de modo a se incorporar efetivamente nas normas o que na realidade em certa medida já existe, a coexistência entre a prestação pública (pela ECT) e as empresas privadas.

\section{V.2.1.2. Natureza jurídica de serviço público na lei $n .^{\circ} 9.074 / 95$}

Em maio de 1998 a lei n. ${ }^{\circ} 9.648$ incorporou à lei n. ${ }^{\circ}$ 9.074/95 previsão expressa de que os serviços postais sujeitar-se-iam ao regime de concessão ou permissão, nos termos da lei n. ${ }^{\circ} 8.987 / 95$ (art. $1^{\circ}$, VII ${ }^{131}$ ). Diante disso, pode-se afirmar que na legislação há expressa referência ao serviço postal como serviço público em disposição formal da lei federal n. ${ }^{\circ} 9.074 / 95$.

\footnotetext{
129 “Art. 22. Compete privativamente à União legislar sobre: V - serviço postal”. Sobre a competência privativa da União para legislar sobre serviços postais, ver a decisão do STF na ADI n. ${ }^{\circ}$ 3.080-9/SC, em que o Tribunal manifestou seu entendimento pacífico de que normas estaduais que tenham como objeto matérias de competência legislativa privativa da União são inconstitucionais.

${ }^{130}$ Outra referência constitucional relacionada ao setor postal é encontrada apenas no art. 50, XII, que prescreve a inviolabilidade do sigilo da correspondência.

131 “Art. $1^{o}$. Sujeitam-se ao regime de concessão ou, quando couber, de permissão, nos termos da Lei $n^{o}$ 8.987, de 13 de fevereiro de 1995, os seguintes serviços e obras públicas de competência da União: VII - os serviços postais. (Incluído pela Lei n. ${ }^{\circ} 9.648$, de 1998)".
} 


\section{V.2.2. Uniformização da natureza jurídica do serviço postal pela doutrina brasileira e suas armadilhas}

\section{V.2.2.1. Elementos material e formal da noção de serviço público}

De maneira geral, os doutrinadores se referem a dois aspectos necessários para determinar se certa atividade pode ser qualificada como serviço público. Um elemento, de caráter essencialista ou material, relaciona-se à própria atividade que, em razão de sua vinculação ao interesse da coletividade num determinado momento histórico, será tida como serviço público. O outro elemento do conceito, convencionalista-legalista ou formal, relaciona-se à necessidade de o ordenamento jurídico prever constitucionalmente ou através da lei a caracterização da atividade como serviço público ${ }^{132}$. A abordagem desses dois aspectos subsidiará a posterior análise do modo como o serviço postal é tratado na doutrina.

\footnotetext{
${ }^{132}$ Cf. Fernando Herren Aguillar, Controle social dos serviços públicos, p. 126. Eros Grau, por exemplo, adota uma concepção eminentemente essencialista. Entende que a conceituação de serviço público (espécie do gênero atividade econômica em sentido amplo) não advém da submissão da atividade assim caracterizada a um regime jurídico de direito público, pois que a atividade é ou não serviço público, mas não deixa de sê-lo porque prestada por agentes privados. O que faz com que uma atividade seja caracterizada como serviço público é o fato de ser tida num certo momento histórico como atividade de interesse social ( $\mathrm{A}$ ordem econômica na Constituição de 1988, p. 127-128 e 130). Neste sentido, serviços de educação e saúde, por exemplo, permanecem sendo serviços públicos, ainda que prestados pelo setor privado e não pelo Estado (possibilidade conferida pelos arts. 209 e 199 da Constituição, respectivamente) (A ordem econômica na Constituição de 1988, p. 124-125). De maneira diferente, para Celso Antônio Bandeira de Mello, o "traço formal" dos serviços públicos, que lhes confere caráter jurídico e unidade normativa é o regime jurídico de direito público. Ainda que a definição de uma determinada atividade como serviço público leve em conta a assunção pelo Estado das atividades consideradas relevantes (e que por isso não poderiam ser relegadas à iniciativa privada) e a fruição singular pelos administrados ("substrato material" dos serviços públicos), o traço caracterizador do serviço público é o regime de direito público. Nesse sentido, para ele, os serviços de educação e saúde (os quais o Estado tem obrigação de prestar, mas sem reserva de regime) seriam serviços públicos quando prestados pelo Estado, mas assim não seriam caracterizados se prestados pelos particulares, caso em que serão considerados atividades econômicas (Curso de direito administrativo, p. 636-637).
} 


\section{V.2.2.2. Corrente majoritária: serviço postal como serviço público por definição constitucional e suas consequências}

Em linha com uma concepção formal de serviços públicos, grande parte dos doutrinadores extrai da própria redação constitucional, especificamente das competências atribuídas à União (art. 21, X), essa natureza jurídica do serviço. A partir da repartição de competências entre os entes federativos ${ }^{133}$, o serviço postal seria um serviço público "por determinação/definição constitucional”. Nessa linha estão autores como Celso Antônio Bandeira de Mello ${ }^{134}$, Dinorá Adelaide Musetti Grotti ${ }^{135}$, Eros Grau ${ }^{136}$, Fernando Herren Aguillar $^{137}$, Floriano de Azevedo Marques Neto ${ }^{138}$, Maria Sylvia Zanella Di Pietro ${ }^{139}$ e Odete Medauar $^{140}$.

${ }^{133}$ Primando por um federalismo tripartido, a Constituição de 1988 repartiu competências entre União, Estados e Municípios. Em seu art. 25, estabeleceu as competências estaduais, no art. 30 previu as competências municipais e no art. 21 as federais. Nos moldes do art. 25, §1 $1^{\circ}$ da Constituição, aos Estados ficam reservadas competências residuais, de modo que ficam a cargo deles os serviços não atribuídos à União ou aos Municípios. A eles também compete a exploração (direta ou mediante concessão) dos serviços locais de gás canalizado. Em razão do que dispõe o art. 30, V da Constituição, os Municípios ficam encarregados da prestação (direta ou mediante concessão ou permissão) dos serviços públicos de interesse local, incluído aí o de transporte coletivo. As competências da União, por sua vez, foram listadas explicitamente no texto do art. 21 da Constituição.

${ }^{134}$ Celso Antônio Bandeira de Mello, Curso de direito administrativo, p. 642-643. Segundo o autor, "A Carta Magna do País já indica, expressamente, alguns serviços antecipadamente propostos como da alçada do Poder Público federal. Serão, pois, obrigatoriamente serviços públicos (...) os arrolados como de competência das entidades públicas. No que concerne à esfera federal, é o que se passa com o serviço postal e o Correio Aéreo Nacional (art. 21, X, da Constituição)...".

${ }^{135}$ Dinorá Adelaide Musetti Grotti, O serviço público e a Constituição brasileira de 1988, p. 91-92. Nesse sentido, a autora afirma: “...o art. 21 lista atividades que somente podem ser desempenhadas diretamente pela União ou mediante autorização, permissão ou concessão, o que importa necessariamente no reconhecimento de que são serviços públicos...".

${ }^{136}$ Eros Grau, A ordem econômica na Constituição de 1988, p. 125. De acordo com o jurista, “(...) ao texto do art. 21 da Constituição de 1988 extraímos a conclusão de que há serviço público, de titularidade da União, na prestação dos serviços referidos nos seus incisos X, XI e XII".

${ }^{137}$ Fernando Herren Aguillar, Controle social de serviços públicos, p. 135. O autor, após se convencer de que as contribuições doutrinárias sobre o conceito de serviço público têm um caráter apenas didático e que o que determina se certa atividade é ou não serviço público é a previsão constitucional, afirma que o art. 21 da Constituição apresenta uma lista (não taxativa) de serviços que “...somente podem ser desempenhados pela União". Segundo ele, "[s]obre tais atividades não resta dúvida de que se cuida de serviços públicos, porque se trata de atividades econômicas que somente podem ser desempenhadas pelos particulares nas hipóteses previstas no art. 175, ou seja, mediante concessão ou permissão".

${ }^{138}$ Floriano de Azevedo Marques Neto, "Reestruturação do setor postal brasileiro", Revista Trimestral de Direito Público, v. 19, p. 157 e 168. Ao procurar delinear a exata dimensão do disposto no art. 21, X da Constituição, o jurista afirma que o artigo "...prescreve três ordens de disposições: define o serviço postal como um serviço público, o qual, dentro do pacto federativo, é de titularidade da União (ou seja está no rol de suas competências materiais); e, por fim, estabelece a esta o ônus de prover o necessário à existência deste serviço, que deve ser contínua e universalmente posto à disposição dos administrados". 
Em razão do silêncio constitucional em relação à possibilidade de trespasse dos serviços à iniciativa privada através de contratos de delegação de serviços públicos, diferentemente do que o texto da Constituição faz em relação a outros serviços previstos no art. $21^{141}$, Celso Antônio Bandeira de Mello chega mesmo a afirmar que o art. 21, X deve ser lido de modo tal que seja obrigatório à União prestar os serviços postais diretamente e com exclusividade, havendo, portanto, uma vedação à prestação por particulares, através de concessões, permissões e autorizações ${ }^{142}$. Se para esse autor é vedado aos particulares prestarem os serviços através de contratos de delegação, com mais razão ainda não poderiam prestar os serviços em regime privado.

Para Celso Antônio Bandeira de Mello o silêncio constitucional em relação à possibilidade de outorga aos particulares do serviço postal por meio de concessão ou permissão ensejaria a exclusividade da prestação do serviço pelo Estado. Para Luís Roberto Barroso (posição minoritária), ao revés, o silêncio da Constituição deve ser entendido como uma amostra de que o serviço postal é uma atividade econômica, pois o texto constitucional, ao prever a competência da União de manter o serviço postal (silente o texto no que se refere à exploração direta ou mediante delegação), estaria apenas assegurando que o poder público federal garantisse um mínimo de exercício da atividade postal, o que não impediria que os particulares também prestassem a atividade ${ }^{143}$.

\footnotetext{
${ }^{139}$ Maria Sylvia Zanella Di Pietro, Direito administrativo, p. 101-102. Nas palavras da autora, "é o Estado, por meio de lei, que escolhe quais as atividades que, em determinado momento, são consideradas serviços públicos; no direito brasileiro, a própria Constituição faz essa indicação nos artigos 21, incisos X...”.

140 Odete Medauar, Direito administrativo moderno, p. 327. Segundo a autora, "A competência para a prestação de serviços públicos decorre da repartição de competências prevista na Constituição Federal".

141 A Constituição de 1988 refere-se expressamente à possibilidade de serem celebrados contratos de delegação com particulares em relação aos serviços de telecomunicações (inciso X), aos serviços arrolados no inciso XII (radiodifusão sonora e de sons e imagens, energia elétrica, navegação aérea, aeroespacial e infraestrutura aeroportuária, transporte ferroviário e aquaviário, transporte rodoviário, portos marítimos, fluviais e lacustres) e aos serviços e instalações nucleares (o texto permite que sob regime de permissão sejam autorizadas a comercialização e utilização de radioisótopos em determinados casos, cf. inciso XXIII, alíneas "b" e "c").

${ }^{142}$ Celso Antônio Bandeira de Mello, Curso de direito administrativo, p. 645.

${ }^{143}$ Luís Roberto Barroso, "Regime constitucional do serviço postal: legitimidade da atuação da iniciativa privada”, Revista de Direito Administrativo, n. ${ }^{\circ} 22$, p. 209.
} 
Na linha de Luís Roberto Barroso, apenas se o texto falasse da possibilidade de delegação do serviço é que este poderia ser considerado serviço público, pois com isso se operaria a retirada, por opção política, da atividade postal do domínio da livre-iniciativa, uma vez que o serviço postal não poderia ser considerado serviço público inerente (que, por ser ligado às funções estatais típicas, independeria de previsão do direito positivo) ${ }^{144}$.

A partir desse cenário das discussões doutrinárias a respeito do serviço postal, procurar-se-á explorar a ideia segundo a qual a caracterização do serviço como serviço público, do modo como tem sido feita, apresenta alguns problemas. De maneira geral, a doutrina tende a privilegiar uma leitura literal da Constituição, por vezes vinculada aos alinhamentos dos autores sobre o papel que o Estado tem na economia ${ }^{145}$, leitura que se no passado era capaz de resolver as discussões, hoje se apresenta um tanto quanto descolada da realidade setorial, que é marcada pela complexidade das atividades postais e pela proliferação de agentes econômicos que as exploram.

Primeiro, é bastante discutível que da competência da União para "manter" o serviço postal se extraia a forma de prestação do serviço por particulares. Claramente a Constituição confere à União o direito de explorar tal atividade, o dever de mantê-la funcionando adequadamente (e, nesse sentido, de assegurar sua prestação mínima a toda a coletividade - pressuposto da universalização, e contínua - pressuposto da continuidade) e de regulá-la (de sobre ela legislar).

\footnotetext{
${ }^{144}$ Luís Roberto Barroso, "Regime constitucional do serviço postal: legitimidade da atuação da iniciativa privada", Revista de Direito Administrativo, n. ${ }^{\circ} 22$, p. 203. Segundo o autor, fosse serviço público, a lei ordinária não teria motivo para instituir monopólio no setor postal, como de fato fez. Bastaria que sua prestação não fosse concedida ou permitida para seu desempenho ser exclusivamente estatal (ibidem, p. 203). E fosse considerado serviço público pela ECT, ela não teria franqueado sua atividade (por simples contrato e não nos moldes do que prevê o art. 175 da Constituição) (ibidem, p. 205-206). Como atividade econômica que é, o serviço postal poderia a princípio, quanto à forma de atuação estatal, ser prestado sob forma monopolizada ou sob forma não monopolizada e regime concorrencial. Como apenas subsistiriam os monopólios previstos no art. 177 da Constituição e não seria possível ampliar-se o rol de monopólios por lei (do que não seria possível considerar-se que a lei que previa o monopólio dos serviços postais - lei n. ${ }^{\circ}$ 6.538/78 - teria sido recepcionada pela nova ordem constitucional) (ibidem, p. 208 e 210), “...a prestação de serviços postais pelo Estado deve ser entendida como forma de exploração estatal de atividade econômica não monopolizada" e sob regime concorrencial (ibidem, p. 208), sendo, pois, livre aos particulares “...os serviços de entrega, recebimento, expedição e transporte de objetos de correspondências, valores ou encomendas, independentemente de ato de delegação prévia do Poder Público” (ibidem, p. 208).

${ }^{145}$ Celso Antônio Bandeira de Mello, por exemplo, é um autor sabidamente contrário à redução do papel do Estado na economia (o que é refletido na sua opinião de que o serviço postal é de prestação obrigatória e exclusiva da União). Luís Roberto Barroso, por sua vez, é advogado das empresas de distribuição, de modo que sua opinião de que o serviço postal é atividade econômica não está imune à parcialidade.
} 
Mas daí a afirmar que o serviço postal é serviço público, podendo apenas ser prestado por particulares em regime de direito público, ou nem mesmo através de contratos de concessão e permissão, há uma grande diferença. Esse entendimento tem importância significativa, pois a partir dele procurar-se-á afirmar que a Constituição não restringiu as opções do legislador, de modo que a legislação infraconstitucional tem ampla margem para fixar novas regras para o setor em eventual reestruturação.

Nesse sentido, adotando-se como pressuposto que a Constituição não oferece resposta explícita sobre a natureza jurídica do serviço postal e, portanto, sobre a forma de sua prestação, e tomando-se por base os dois elementos utilizados pela doutrina para que uma atividade seja caracterizada como serviço público (o traço material e o formal), verifica-se que a definição da natureza jurídica do serviço deveria levar em consideração a essencialidade do serviço e a legislação setorial, que ao menos teoricamente deveria cumprir um papel importante de delinear a forma pela qual os serviços são prestados pelos diversos agentes econômicos exploradores das atividades postais.

Adotar o elemento material do serviço público implica em levar em conta a alteração verificada no conteúdo concreto das atividades consideradas "serviços postais" (integrantes do que denominamos de rede postal), e os diferentes graus de essencialidade que cada uma delas tem para a coletividade. De maneira geral, a doutrina não trata desse aspecto em relação ao setor postal brasileiro. De outro lado, especialmente partindo-se da ideia segundo a qual do texto constitucional não se extrai a natureza jurídica do serviço postal, é necessário analisar se a legislação setorial dá contornos precisos à possibilidade de exploração do serviço por particulares. Trata-se de outro aspecto pouco explorado pela doutrina nacional.

A análise da legislação setorial permite afirmar, no entanto, que ela não é capaz de conferir contornos precisos à questão da forma de prestação do serviço, seja porque é em grande medida afastada da realidade setorial, seja porque é até certo ponto insuficiente e contraditória. Importante demarcar, no entanto, como visto, que na lei federal n. ${ }^{\circ}$ 9.074/95 há expressa referência de que os serviços postais devem sujeitar-se aos regimes de concessão ou permissão. Essa referência expressa do serviço postal como serviço público em disposição formal da lei afasta-se tanto do entendimento de Celso Antônio Bandeira de Mello quanto do de Luís Roberto Barroso, que ambos, obviamente, consideram essa lei inconstitucional. 
Porém, a realidade setorial vai muito além da exploração do serviço postal por particulares através desses contratos de delegação. Na prática, a partir da década de 1990, o serviço tem sido prestado por permissionários (típica forma de delegação de serviços públicos), mas os particulares também vêm explorando serviços postais através de contratos de franquia, até hoje celebrados no setor postal sem necessidade de licitação e sem lei que estabeleça os contornos das contratações.

Além disso, os serviços também vêm sendo prestados por prestadores que não receberam qualquer autorização legal ou mesmo contratual para a prestação dos serviços. Esses particulares têm disputado fatias do mercado postal em regime de competição, tal como se o serviço postal (ou ao menos as atividades mais lucrativas da rede postal, como a entrega de encomendas) fosse atividade econômica, submetido ao regime jurídico de direito privado. Esses particulares, como mencionado anteriormente, ocupam uma considerável parcela do mercado postal e ao longo do tempo vêm pretendendo aumentar sua atuação nele. Nesse sentido, atualmente cerca de $25 \%$ dos serviços postais são prestados através de agências franqueadas, em sua maioria escolhidas sem procedimento licitatório anterior à celebração dos contratos com a ECT, e no final de 2003 atuavam no setor cerca de 15.000 empresas privadas de distribuição de serviços postais.

Ao que tudo indica, as franquias postais se submeterão a um novo regime jurídico. Os novos contratos de franquia (Correios Conveniência) serão disciplinados pela lei n. ${ }^{\circ}$ 11.668/08 e pelo decreto n. $^{\circ} 6.639 / 08$, um modelo diferente do que atualmente está sendo operado e que já tem sido implantado, inclusive outorgado mediante prévio procedimento licitatório.

Porém, ainda que seja resolvida a situação irregular das franquias postais, persiste o problema da prestação do serviço postal por esses 15.000 agentes econômicos que exploram atividades postais sem qualquer autorização legal para a prestação dos serviços. Em linha com o entendimento segundo o qual o serviço postal é serviço público (o que envolve todas as atividades integrantes da rede postal), partindo-se da dicotomia serviços públicos versus atividades econômicas, para que essas empresas privadas pudessem explorar serviços postais elas deveriam ter participado de um certame licitatório, ao final do qual celebrassem com o poder público um contrato de concessão ou permissão ${ }^{146}$.

\footnotetext{
146 Pode-se ainda cogitar da autorização de serviço público, o que, no entanto, seria questionável. A esse respeito, ver Odete Medauar, Direito administrativo moderno, p. 337; Marçal Justen Filho, Curso de direito administrativo, p. 801-802; e Alexandre Santos de Aragão, Direito dos serviços públicos, p. 725-730.
} 
Assim, seria necessário que tivessem sido estabelecidas condições objetivas e subjetivas que, uma vez preenchidas, possibilitassem a uma pessoa jurídica prestar os serviços postais.

A partir desse raciocínio, seguido o entendimento amplamente difundido na doutrina nacional, atuam no setor postal agentes econômicos com forte poder de barganha e interesses antagônicos, que competem num mercado sem regras claras, sem regulação setorial efetiva que forneça condições mínimas para se garantir o equilíbrio entre esses agentes, num setor importante para o país.

Diante disso, as próprias consequências de se eleger um serviço à categoria de serviço público (em sentido amplo) acabam sendo descaracterizadas ${ }^{147}$. O poder público não está se valendo de mecanismos que lhe permitam restringir o acesso a quem queira explorar os serviços postais, as atividades dos prestadores não têm sido reguladas (ao menos não de maneira ordenada e clara) e há uma preocupação um tanto quanto marginal do poder público em se comprometer e fazer com que as empresas privadas se comprometam em assegurar que o serviço postal exista e seja acessível a toda a sociedade.

Nesse sentido, especialmente levando-se em consideração a realidade setorial, pode-se questionar se realmente faz sentido extrair do texto constitucional (art. 21, X) a natureza jurídica do serviço postal. Será que a resposta à questão de qual é a natureza jurídica do serviço se resume (ou deve se resumir) apenas a um esforço dogmático de qual é a interpretação correta do verbo "manter" da Constituição?

Segundo Alexandre Santos de Aragão, há dois casos em que as leis que regulam setores de serviços públicos fazem referência à autorização: (i) ou a atividade autorizada integra o setor, mas não é serviço público; ou (ii) caso verse sobre serviço público, estar-se-á diante não de uma autorização, mas sim de uma delegação de serviço público, caso em que haverá uma autorização apenas nominal, mas na prática a autorização será contratual. Ao tratar da possibilidade de uso da autorização para prestação de serviço público, Vera Monteiro afirma que a resposta a essa questão depende em grande medida do que se entende por serviço público. Caso se parta da classificação que opõe serviços públicos e atividades econômicas em sentido estrito, “...a autorização seria ato de polícia administrativa por meio do qual se disciplinaria o exercício de direitos ou liberdades próprias dos particulares e, por isso mesmo, comparável à licença" (Concessão, p. 85). De outro lado, segundo a autora, adotar-se a visão segundo a qual serviço público engloba "...atividades relevantes $e$ de interesse público, independentemente do regime por meio do qual ele é prestado" traz como consequência a aceitação de que “...a autorização também pode ser instrumento para a transferência a particulares de atividades públicas, legitimando o desenvolvimento de atividades tradicionalmente tidas como serviço público, como é o caso dos serviços de telecomunicações" (Concessão, p. 86). Diante disso, a autora conclui que "[e]m suma, a depender do que se entende por 'serviço público', é possível aceitar que a autorização seja instrumento para a transferência de serviço público a particulares" (Concessão, p. 87).

${ }^{147}$ Valho-me aqui das principais consequências apontadas por Floriano de Azevedo Marques Neto, oriundas do fato de uma certa atividade ser caracterizada como serviço público. Cf. "A nova regulação dos serviços públicos", Revista de Direito Administrativo, v. 228, p. 22. 


\section{V.2.3. Análise crítica da judicialização dos privilégios da impenhorabilidade de bens e da imunidade tributária recíproca: as armadilhas da uniformização da natureza jurídica do serviço postal}

Esse cenário complexo do setor postal brasileiro, marcado pela expansão das atividades postais e pelo aumento de prestadoras do serviço, tem levado a uma judicialização reiterada dos conflitos que envolvem a ECT, as agências franqueadas e as empresas privadas. Em grande medida, esses conflitos relacionam-se ao regime peculiar conferido à estatal pelo decreto-lei n. ${ }^{\circ}$ 509, de 20 de março de 1969 que, ao criá-la como empresa pública, conferiu-lhe diversos privilégios, próprios da Fazenda Pública (impenhorabilidade de bens, rendas e serviços, imunidade tributária ${ }^{148}$, e também no concernente a foro, prazos e custas processuais) ${ }^{149}$ e lhe garantiu a exploração de algumas atividades em regime de "monopólio"150.

Através da pesquisa realizada junto ao STF, verificou-se que entre 1990 e 2011 muitos credores da ECT, especialmente os credores trabalhistas, insurgiram-se contra a possibilidade de a execução de seus créditos dar-se mediante o sistema de precatórios. No mesmo período, também foram muitos os Estados e Municípios brasileiros que questionaram a imunidade tributária da estatal. Em Anexo a esta dissertação (item VIII) é apresentado o relato dos acórdãos do STF que subsidiaram a elaboração deste terceiro capítulo.

A partir da leitura desses acórdãos do STF e do mapeamento dos principais temas neles discutidos e decididos, verifica-se que o Tribunal, do ano de 1990 até dezembro de 2011, se manifestou sobre o tema da impenhorabilidade dos bens da ECT por 24 vezes, fixando entendimento segundo o qual os bens da estatal são impenhoráveis, devendo a execução contra ela fazer-se mediante o sistema de precatórios. No mesmo período, através de 27 decisões, consolidou entendimento segundo o qual a ECT está abrangida pela imunidade tributária.

\footnotetext{
${ }^{148}$ Conforme nota de rodapé anterior, que reitero, o decreto-lei n. ${ }^{\text {o }}$ 509/69 conferiu expressamente à ECT o privilégio da imunidade tributária (art. 12), mas tecnicamente se ela decorresse apenas da legislação infraconstitucional, seria uma isenção. Na prática, o STF tem fundamentado suas decisões no art. 150, VI, "a", da Constituição, que trata da imunidade recíproca.

${ }^{149}$ Cf. art. 12 do decreto-lei n. ${ }^{\circ} 509 / 69$.

${ }^{150}$ Cf. art. $2^{\circ}$, I do decreto-lei n. ${ }^{\circ} 509 / 69$. O monopólio foi posteriormente delimitado pela lei n. ${ }^{\circ} 6.538 / 78$.
} 
A validação ${ }^{151}$ desses privilégios legais à estatal fundamenta-se em grande medida no entendimento da Corte de que a ECT é prestadora de serviço público, posicionamento esse que parte da dicotomia serviços públicos versus atividades econômicas. Na grande maioria dos casos, tal como faz a doutrina, esta natureza jurídica de serviço público advém da leitura literal do verbo "manter" da Constituição (CF, art. 21, X).

Nesse sentido, foi o voto do ministro Nelson Jobim, representante da corrente majoritária (alinhada à tese conduzida pelo ministro Maurício Corrêa) no julgamento conjunto de 16 de novembro de 2000 (RE n. ${ }^{\circ}$ 220.906-9/DF; RE n. ${ }^{\circ}$ 225.011-0/MG; RE n. ${ }^{\circ}$ 229.696-7/PE; RE n. ${ }^{\circ}$ 230.072-3/RS e RE n. ${ }^{\circ}$ 230.051-6/SP), que defendeu que o serviço postal é por definição constitucional um serviço público. Trata-se, segundo o ministro, de serviço que integra os fins do Estado e que " $E$, por isso e por opção positivada na norma constitucional, um serviço público" ${ }^{152}$.

A partir do julgamento desses casos, o STF assentou firme entendimento segundo o qual o decreto-lei n. ${ }^{\circ}$ 509/69 (que estendeu à ECT privilégios conferidos à Fazenda Pública, dentre eles a impenhorabilidade de seus bens, rendas e serviços) foi recepcionado e os bens da ECT são impenhoráveis por ser empresa pública prestadora de serviço público, conforme prevê a Constituição.

De maneira semelhante, no julgamento do RE n. ${ }^{\mathbf{0}}$ 407.099-5/RS, que serviu de precedente para o STF fixar entendimento segundo o qual a ECT goza de imunidade tributária, no voto condutor do ministro Carlos Velloso ele afirma que o serviço postal é “...serviço público de prestação obrigatória e exclusiva do Estado: CF, art. 21, X”,153. Exatamente no mesmo sentido foi o posicionamento do ministro Eros Grau no julgamento da Ação Cível Originária n. ${ }^{\mathbf{7}}$ 765-1/RJ, de acordo com o qual “.... E Empresa Brasileira de Correios e Telégrafos é uma empresa prestadora de serviço público. Está previsto no art. 21 da Constituição" ${ }^{\prime 154}$.

\footnotetext{
${ }^{151}$ O termo "validação" é utilizado nesta pesquisa (inclusive no item V.2.3.3) como sinônimo de "legitimar", "declarar válido". Os privilégios da ECT, por exemplo, advieram da legislação, e foram declarados válidos pelo STF nas oportunidades em que se manifestou sobre o tema.

${ }^{152} \mathrm{RE} \mathrm{n.}^{\circ} 220.906-9 / \mathrm{DF}$, p. 470.

${ }^{153}$ RE n. $^{\circ} 407.099-5 /$ RS, p. 1560.

${ }^{154} \mathrm{ACO}$ n. ${ }^{\circ} 765-1 / \mathrm{RJ}$, p. 18.
} 
A esse respeito, interessante também retomar o debate travado no julgamento do Ag. Reg. no RE n. 328.843-1/MG, em que os ministros Marco Aurélio (voto vencido) e Eros Grau discordaram a respeito da natureza jurídica do serviço postal. Para o primeiro, a redação constitucional apenas revela que a União manterá o serviço. Para o segundo, ao revés, a ECT presta atividade exclusivamente pública porque a própria Constituição assim diz. E encerra o debate com a seguinte frase: "Perdoe-me Vossa Excelência, acho que tenho a meu favor a doutrina. Posso enunciar quem diz que é serviço público" ${ }^{\text {"155. }}$.

De maneira geral, a análise dos acórdãos nos permite afirmar que ficam em segundo plano a discussão sobre a essencialidade do serviço (aspecto material dos serviços públicos), as previsões da legislação setorial (o aspecto formal do conceito de serviço público é analisado apenas em relação ao texto constitucional) e a própria realidade do setor postal (a complexidade das atividades da rede postal e o aumento das formas de prestação dos serviços). A questão também se enfraquece porque tratada em grande medida sem se definir o que vem a ser serviço postal. Faltam, assim, argumentos consistentes a respaldarem o entendimento segundo o qual o serviço postal tem a natureza jurídica de serviço público.

Mesmo a discussão sobre o motivo pelo qual o ordenamento jurídico confere a alguns entes a prerrogativa de se valer da impenhorabilidade de seus bens e da imunidade tributária em grande medida tem um caráter bastante secundário nas discussões entre os ministros.

No entanto, será mesmo que uma leitura literal da Constituição ou mesmo apenas os posicionamentos doutrinários (de quem diz que é serviço público) conseguem resolver os problemas do setor postal? Será que as discussões a respeito do setor devem se circunscrever a esses debates? Qual é a função de se reconhecer a uma determinada entidade a impenhorabilidade de seus bens e a imunidade tributária? Há efetivamente uma preocupação por parte dos ministros de resguardar os bens e serviços públicos?

Analisadas essas questões nos casos concretos, verifica-se que essa jurisprudência que parte da dicotomia serviços públicos versus atividades econômicas e consagra e propaga um regime jurídico único, fortemente "publicístico", aplicável a todas as atividades integrantes da rede postal, traz em si uma armadilha, problemas práticos que advêm quando se comparam os entendimentos firmados pelo Tribunal com a realidade setorial. São consequências das decisões da Corte que muitas vezes têm um papel bastante

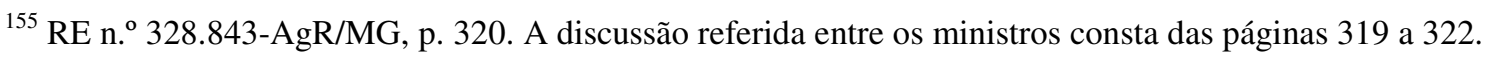


secundário quando ela decide os conflitos que lhe são direcionados. Mas que impactam de maneira significativa (positiva ou negativa) na realidade setorial, fazendo com que as regras que lhe são aplicáveis sejam mais ou menos claras e consistentes para organizar de maneira adequada a exploração dos serviços.

De maneira geral, procurar-se-á desenvolver a ideia segundo a qual a consolidação desse regime jurídico único cria os seguintes problemas práticos para o setor postal brasileiro (a ideia de armadilhas): o conteúdo do serviço postal foi delimitado de maneira incerta, há necessidade de avaliar-se a função dos privilégios postais e seu impacto sobre a competição do setor, as decisões do STF contribuem para que os operadores privados tornem-se um setor paralelo e acarretam um impacto sobre as franquias postais. Essas ideias serão desenvolvidas na sequência.

\section{V.2.3.1. Delimitação incerta do conteúdo do serviço postal}

A leitura dessas decisões do STF permite afirmar que o Tribunal tem reconhecido um tratamento diferenciado à ECT, em razão da natureza jurídica das atividades que presta (serviços públicos). A dicotomia serviços públicos versus atividades econômicas (anteriormente analisada), assim, não tem sido utilizada apenas com vistas a determinar se um dado serviço poderá ser desempenhado por particulares através de contratos de concessão e permissão, ou se será livre a sua prestação, independentemente de qualquer vínculo de outorga.

Com base nessa dicotomia, que também é bastante questionável no que tange ao regime jurídico das estatais ${ }^{156}$, a estatal tem recebido um tratamento diferenciado, sujeitando-se a um regime jurídico em certa medida dotado de privilégios (inicialmente

\footnotetext{
${ }^{156}$ Cf. Carlos Ari Sundfeld; Rodrigo Pagani de Souza, "Licitação nas estatais: levando a natureza empresarial a sério", Revista de Direito Administrativo, v. 245, p. 21. Os autores apresentam a distinção, mas são bastante críticos em relação a ela. Segundo eles, mesmo no que tange ao regime das estatais, a utilidade da distinção "serviços públicos" versus "atividades econômicas" é bastante questionável. Isso especialmente porque a distinção mostra sinais de crise, ante a legislação brasileira, que tem reconhecido, por exemplo, serviços públicos subordinados não ao regime publicístico, mas sim ao regime de direito privado ("Licitação nas estatais: levando a natureza empresarial a sério", Revista de Direito Administrativo, v. 245, p. 22). Também é bastante crítico em relação a essa distinção Floriano de Azevedo Marques Neto, segundo o qual "O que me parece hoje relevante para se verificar o regime jurídico a balizar a atividade da empresa estatal será a atividade que exerce e se a mesma se desenvolve em regime de competição ou não" ("As contratações estratégicas das estatais que competem no mercado". In: OSÓRIO, Fábio Medina; SOUTO, Marcos Juruena Villela (coords.). Direito administrativo: estudos em homenagem a Diogo de Figueiredo Moreira Neto, p. $581)$.
} 


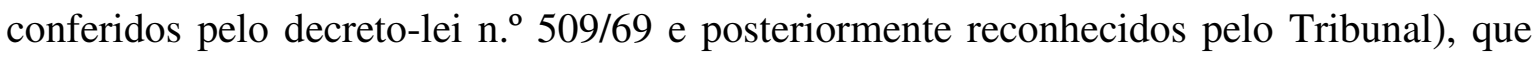
lhe garantem vantagens que não são extensivas às empresas do setor privado, tampouco às estatais prestadoras de atividades econômicas.

É inerente à escolha pelo formato empresarial que a estatal se submeta a um regime jurídico com traços privados, aplicáveis a qualquer empresa do setor privado. A essas regras comuns, somam-se outras, regras próprias, aplicáveis apenas às empresas estatais. É que, diferentemente do que ocorre com as empresas privadas, a atuação das estatais não estará limitada apenas à realização do objeto social, mas também ao interesse público específico que justificou sua criação ${ }^{157}$. Ademais, as estatais pertencem à estrutura da Administração Pública, o que também justifica sua sujeição a um regime jurídico híbrido, com forte influência do regime jurídico público.

Em sua dissertação de mestrado, Henrique Motta Pinto, tendo como parâmetro o regime jurídico empresarial básico, de direito privado, aplicável às empresas do setor privado, propõe uma classificação bastante didática a respeito das normas aplicáveis às empresas estatais, que genericamente denomina excepcionalidades ${ }^{158}$. O autor então reparte essa categoria genérica de excepcionalidades em três espécies de normas, “...conforme elas sejam neutras, restritivas ou vantajosas, diante das normas excepcionadas" ${ }^{\prime 159}$. A essas espécies ele dá o nome de peculiaridades, limitações e privilégios.

Seguindo a classificação do autor, as peculiaridades são normas neutras, que não geram nem restrições nem vantagens às empresas estatais. É o caso, por exemplo, do art. 109, I da Constituição, que confere à Justiça Federal competência para processar e julgar as causas em que empresas públicas federais forem interessadas "...na condição de autoras, rés, assistentes ou oponentes, exceto as de falência, as de acidentes de trabalho e as sujeitas à Justiça Eleitoral e à Justiça do Trabalho". Como afirma Henrique Motta Pinto, essa norma parece ter sua motivação em razões de administração judiciária, não tendo por escopo nem criar uma vantagem à atuação das empresas públicas federais, nem criar uma

\footnotetext{
${ }^{157}$ Sobre essa dupla função das estatais, cf. Mario Engler Pinto Junior, O estado como acionista controlador, p. 13 e ss.; Henrique Motta Pinto, Empresa estatal: modelo jurídico em crise?, p. 9 e ss. Ver a respeito Dinorá Adelaide Musetti Grotti, "O regime jurídico das empresas estatais". In: WAGNER JUNIOR, Luiz Guilherme da Costa (coord.). Direito Público: estudos em homenagem ao professor Adilson Abreu Dallari, p. 130-136.

${ }^{158}$ Henrique Motta Pinto, Empresa estatal: modelo jurídico em crise?, p. 44. Sobre as peculiaridades, ver páginas 45 a 47; sobre as limitações, ver páginas 47 a 72 e sobre os privilégios, ver páginas 72 a 78.

${ }^{159}$ Henrique Motta Pinto, Empresa estatal: modelo jurídico em crise?
} 
restrição à sua atuação. Possuir foro na Justiça Federal e não na Estadual seria, assim, uma norma neutra.

Ainda tomando por base a classificação de Henrique Motta Pinto, as limitações são regras restritivas à atuação empresarial do Estado, que têm o condão de limitar e condicionar seu agir empresarial. É o caso, por exemplo, da sujeição das estatais a procedimento licitatório para contratar serviços e obras, alienar e comprar bens $(\mathrm{CF}$, art. 22, XXVII; art. 37, XXI e art. 173, §1 ${ }^{\circ}$, III), com vistas a garantir processos isonômicos de compra entre todos os potenciais fornecedores e a obter condições mais vantajosas às contratações.

É o caso também da sujeição das estatais ao dever de realizar concurso público $(\mathrm{CF}$, art. 37, II), rito específico que objetiva conferir chances iguais a todos os que pretendam compor os quadros da Administração e assegurar que os profissionais que passem a integrá-los o façam por razões objetivas, relacionadas à sua competência para desempenhar suas funções. Dentro das chamadas limitações está também a sujeição das estatais ao controle interno da Administração, ao controle externo pelo Tribunal de Contas $(\mathrm{CF}$, art. 49, X; 70 e 71) e ao controle jurisdicional, de modo a se garantir a adequada gestão dos recursos públicos e a adstrição à legalidade.

Por fim, os privilégios, de acordo com a classificação proposta por Henrique Motta Pinto, são vantagens atribuídas às empresas estatais, não extensíveis às empresas do setor privado. $\mathrm{O}$ autor dá os seguintes exemplos de privilégios ${ }^{160}$ : impenhorabilidade dos bens das pessoas de direito público (CF, art. 100; CPC, art. 730), imunidade tributária em relação ao patrimônio, renda e serviços das pessoas de direito público (CF, art. 150, VI, "a", $\S \S 2^{\circ}$ e $3^{\circ}$ ) e prerrogativas processuais da Fazenda Pública, como prazos maiores para realização de atos processuais (conforme art. 188 do CPC e art. 10 da lei n. ${ }^{\circ}$ 9.469/97) e duplo grau obrigatório de jurisdição (CPC, art. 475, I e II).

${ }^{160}$ Henrique Motta Pinto, Empresa estatal: modelo jurídico em crise?, p. 75. 
No caso do setor postal, e tendo por base a classificação proposta por Henrique Motta Pinto, pode-se afirmar que a legislação setorial conferiu à ECT privilégios, reconhecidos e mantidos pelo STF nas diversas oportunidades em que foi chamado a se manifestar, com base no fato de ser a ECT prestadora de serviço público. Diante disso, pretende-se sustentar que a jurisprudência (no que vem sendo acompanhada por grande parte da doutrina ${ }^{161}$ ) tem construído ao longo do tempo uma apartação entre as estatais prestadoras de serviços públicos e as prestadoras de atividades econômicas.

Segundo esse entendimento doutrinário, que em grande medida tem sido acompanhado pela jurisprudência ${ }^{162}$, as empresas estatais prestadoras de serviços públicos devem ter um regime muito mais assemelhado ao das entidades públicas, o que é bastante questionável no caso de estatais que prestam serviços públicos em regime de competição, como a ECT.

Por esta razão, o regime jurídico que lhes é aplicável aproxima-se ao das autarquias, sendo inadequadas à ECT as prescrições do art. 173 da Constituição Federal ${ }^{163}$, que substancialmente aproxima as empresas estatais (ou, pode-se entender de maneira mais ampla, as empresas que prestam serviços públicos) das empresas privadas, seja para vedar que as estatais sejam de algum modo privilegiadas (o artigo impede, por exemplo, que as estatais tenham privilégios fiscais não extensivos às empresas do setor privado, conforme $\S 2^{\text {o164}}$ ), seja para possibilitar que elas usufruam, por exemplo, de um regime licitatório mais flexível, para que ele não constitua um entrave a que a estatal seja competitiva no mercado (art. 173, II).

\footnotetext{
${ }^{161}$ Ver a respeito, Dinorá Adelaide Musetti Grotti. "O regime jurídico das empresas estatais". In: WAGNER JUNIOR, Luiz Guilherme da Costa (coord.). Direito Público: estudos em homenagem ao professor Adilson Abreu Dallari, p. 130-136.

${ }^{162}$ Nesse sentido, nos casos analisados, alguns ministros chamaram atenção para a natureza autárquica da ECT. Ver voto do ministro Carlos Velloso no RE n. ${ }^{\circ}$ 220.907-5/RO e no RE n. ${ }^{\circ}$ 407.099-5/RS. Ver também o voto do ministro Menezes Direito na Ação Cível Originária n. ${ }^{\circ}$ 959-4/RN.

${ }^{163}$ Em seu artigo $173, \S 1^{\circ}$, a Constituição determina que lei estabelecerá o estatuto jurídico das empresas estatais que explorem atividade econômica, dispondo sobre: (i) função social e formas de fiscalização pelo Estado e pela sociedade; (ii) sujeição ao regime jurídico próprio das empresas privadas (inclusive no que tange aos direitos e obrigações civis, comerciais, trabalhistas e tributários); (iii) licitação e contratação com observância apenas dos princípios da administração pública; (iv) constituição e funcionamento dos conselhos de administração e fiscal; e (v) mandatos, avaliação de desempenho e responsabilidade dos administradores. Com isso, tem-se entendido que o constituinte objetivou sujeitar as empresas estatais exploradoras de atividades econômicas a um regime diferente do aplicável às prestadoras de serviços públicos.

164 “Art. 173, $\$ 2^{\circ}$. As empresas públicas e as sociedades de economia mista não poderão gozar de privilégios fiscais não extensivos às do setor privado".
} 
Neste sentido, em seu art. $173, \S 1^{\circ}$, III, a Constituição possibilita que lei ordinária trate do regime de licitação aplicável às empresas estatais exploradoras de atividade econômica. Como até o momento essa lei não foi editada, em regra é aplicável a todas as contratações feitas pelas estatais, independentemente da atividade por elas exercida, o regime de contratação da lei n. ${ }^{\circ}$ 8.666/93. Embora essa lei geral não tenha sido editada, algumas leis específicas têm afastado o regime licitatório geral da Administração, definido pela lei n. ${ }^{o}$ 8.666/93. A Lei do Petróleo (lei n. ${ }^{\circ}$ 9.478/97), por exemplo, flexibilizou o regime licitatório da Petrobras, possibilitando que seus contratos para aquisição de bens e serviços sejam precedidos de procedimento licitatório simplificado (art. 67), definido em decreto do Presidente da República (decreto n. ${ }^{0}$ 2.745/98) ${ }^{165}$. Já às empresas estatais exploradoras de atividades econômicas seria aplicável o art. 173 da Constituição.

Ainda que as decisões do STF reconheçam a natureza jurídica de serviço público ao serviço postal e com base nisso confiram à ECT um tratamento diferenciado, reconhecendo-lhe privilégios, a fundamentação ao menos de algumas das decisões revela uma dificuldade dos ministros em aplicar esse regime jurídico privilegiado à ECT.

No julgamento conjunto de 16 de novembro de 2000 (RE n..$^{\circ}$ 220.906-9/DF; RE

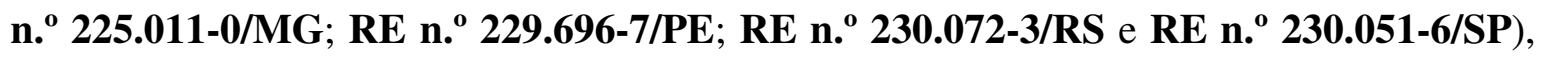
o ministro Ilmar Galvão (voto vencido) chamou atenção para a contradição entre a natureza jurídica de serviço público do serviço postal e sua prestação mediante contratos de franquia ${ }^{166}$. Quem retomou a questão foi o ministro Sepúlveda Pertence (voto vencido), segundo o qual obviamente as franquias eram concessões de serviços públicos ${ }^{167}$. Mas como seriam concessões se não tinham sido precedidas de qualquer procedimento licitatório? E tampouco esses contratos haviam sido celebrados como concessões, de acordo com a legislação reitora?

\footnotetext{
${ }^{165}$ Algumas decisões judiciais e do TCU, no entanto, têm anulado os efeitos dos procedimentos licitatórios da Petrobras, para impor à estatal a observância da lei n. ${ }^{\circ}$ 8.666/93. Por meio de decisões cautelares, no entanto, o STF vem preservando os efeitos desses procedimentos licitatórios, posicionamento-se favoravelmente à modulação de regimes. Ver a esse respeito, medida cautelar no mandado de segurança n. $^{\circ}$ 25.888/DF, interposta contra decisão do TCU e julgada em 22/03/2006; e questão de ordem em medida cautelar na ação cautelar n. ${ }^{\circ}$ 1.193/RJ, interposta contra acórdão do STJ e julgada em 09/05/2006.

${ }^{166} \mathrm{RE}$ n. ${ }^{\circ}$ 220.906-9/DF, esclarecimento do ministro Ilmar Galvão, p. 481 e 482.

${ }^{167} \mathrm{RE} \mathrm{n.}{ }^{\circ} 220.906-9 / \mathrm{DF}$, p. 511.
} 
O debate entre os ministros não resolveu essas questões, mas acabou sendo encerrado com o pronunciamento do ministro Moreira Alves (voto vencedor) dizendo que a emissão de selos é monopólio estatal ${ }^{168}$, afirmação que certamente se distancia do escopo do debate anterior. Pois bem, ainda que as franquias não possam emitir selos, o que dizer do restante de suas atividades, outorgadas a particulares sem prévio certame licitatório?

A questão das franquias ficou em aberto nesse julgamento, tendo sido retomada quando da decisão da Ação Cível Originária n. ${ }^{\circ}$ 765-1/RJ. Neste caso o cerne da discussão foi a extensão do privilégio da imunidade recíproca às agências franqueadas. Porém, o ministro Eros Grau (voto vencedor) levantou a questão da relação entre a natureza jurídica de serviço público do serviço postal e a sua prestação pelas franqueadas. Em seu entender, a prestação do serviço através dessas agências de maneira alguma o descaracterizaria como serviço público.

Em suas palavras: "Se eu pensar na cidade de São Paulo (...) lá há uma empresa concessionária (...) chamava-se MTC, que tinha uma série de franqueados e permitia a outras empresas a prestação do serviço (...). São como empresas franqueadas, sem que isso absolutamente descaracterize o serviço público que (...) é serviço público por definição constitucional..."169. Mas por que absolutamente a prestação do serviço pelas franqueadas não descaracteriza o serviço postal como serviço público? Será que realmente isso é tão claro, como afirma o ministro?

Também no julgamento conjunto de 16 de novembro de 2000, o ministro Marco Aurélio Mello (voto vencido) lembrou que o próprio STF se valia da entrega de correspondências por empresas outras que não a $\mathrm{ECT}^{170}$. Contra isso o ministro Moreira Alves (voto vencedor) afirmou que havia sido feita uma “...construção no sentido de que

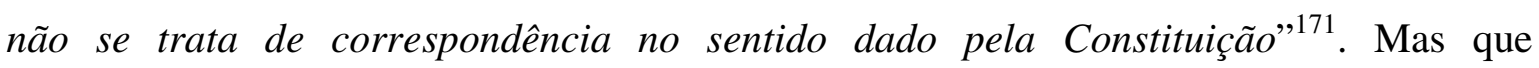
construção é esta? Quais são as suas características? Quem poderia prestar esses serviços? As franqueadas? As empresas privadas em regime de mercado? Ou concessionárias/permissionárias de serviços públicos? São questões que também ficaram em aberto nessa decisão. Assim como também ficou em aberto a questão prática de saber como processar o regime de precatórios em face de uma empresa estatal como a ECT, questão levantada pelo ministro Ilmar Galvão (voto vencido).

\footnotetext{
${ }^{168} \mathrm{RE} \mathrm{n}^{\text {o }} 220.906-9 / \mathrm{DF}$, p. 512.

${ }^{169}$ ACO n. ${ }^{\circ} 765-1 /$ RJ, p. 18.

${ }^{170} \mathrm{RE} \mathrm{n}^{\circ}{ }^{\circ} 220.906-9 / \mathrm{DF}$, p. 511.

${ }^{171} \mathrm{RE} \mathrm{n.}{ }^{\circ}$ 220.906-9/DF, p. 511.
} 
No julgamento conjunto dos agravos regimentais em ações cíveis originárias (Ag. Reg. na Ação Cível Originária n.o 789-2/PI, Ag. Reg. na Ação Cível Originária n.o 814-7/PR e Ag. Reg. na Ação Cível Originária n. ${ }^{0}$ 765-1/RJ), o ministro Ricardo Lewandowski (voto vencido) chamou atenção para a situação das agências franqueadas. Não lhe preocupou, no entanto, a existência de contradição entre a natureza jurídica do serviço postal e sua prestação mediante franquias, mas sim se a isenção de IPVA se estenderia às agências franqueadas, que por competirem com empresas privadas teriam em relação a essas uma condição privilegiada ${ }^{172}$. O ministro ainda ressaltou o fato de que a ECT hoje compete com a iniciativa privada em relação à prestação de alguns serviços e que ela exerce uma série de serviços que não poderiam ser considerados estritamente públicos, como o banco postal, dinheiro fácil e importa fácil ${ }^{173}$. Neste sentido, o ministro Lewandowski chamou atenção para dois pontos importantes para o debate: para o fato de parte das atividades exercidas pela ECT visar apenas o lucro (e nesse sentido, essa parte não corresponderia a serviço público) e para o problema que se causaria caso se acobertassem as agências franqueadas de imunidade tributária (no caso, do não-pagamento de IPVA).

Nessa linha, o ministro Joaquim Barbosa (voto vencido) entendeu que a ECT presta serviços que não são públicos, nem poderiam ser inseridos na categoria de serviços postais, como o banco postal. Essa ponderação, no entanto, haveria de ser feita no julgamento de mérito, uma vez que segundo ele “...os veículos cuja propriedade é tributada com o IPVA são usados para serviços de coleta, remessa ou entrega de correspondência, documentos, objetos, bens e valores" ${ }^{\prime 174}$. Em vista disso o ministro argumentou que o problema da "natureza anfibiológica" da ECT se resolveria com o ente tributante distinguindo as atividades "típicas do Estado" (os serviços públicos, atividades afetadas ao serviço eminentemente postal) das "atividades econômicas" no momento de exercer o seu poder tributário. Estas deveriam ser tributadas.

Mas como fazer essa distinção na prática? Seria realmente possível discriminar para quais serviços a ECT utilizaria seus veículos, limitando-se com isso a imunidade da ECT aos bens e serviços postais convencionais? Em razão desse problema de ordem prática, a própria ministra Ellen Gracie chamou atenção para o fato de que não faz parte da hipótese

\footnotetext{
${ }^{172}$ ACO n. ${ }^{\circ}$ 765-1-AgR/RJ, confirmação de voto ministro Ricardo Lewandowski, p. 25.

${ }^{173}$ ACO n. ${ }^{\circ}$ 765-1-AgR/RJ, p. 21.

${ }^{174}$ ACO n. ${ }^{\circ}$ 765-1-AgR/RJ, p. 19-20.
} 
de incidência do IPVA a forma como a ECT utiliza seus veículos (o imposto é atribuído a débito de quem é proprietário).

Então como fazer para diferenciar o regime jurídico aplicável à ECT em face da natureza jurídica das atividades que presta? Seria o caso de criar uma maneira de tributar os bens da ECT de maneira diferente? E de considerar impenhoráveis apenas os bens afetos especificamente aos serviços postais e telegráficos convencionais? E o que dizer das agências franqueadas, também estariam elas abarcadas por esses privilégios? Os privilégios não poderiam ser estendidos às franqueadas nem à ECT quando prestam serviços em competição com empresas do setor privado?

Essas questões certamente revelam uma dificuldade prática de os ministros delimitarem o conteúdo do serviço postal, o que dificulta a aplicação, com base na legislação do setor postal, do regime jurídico da ECT (e das franquias), que claramente é constituído a partir do núcleo de serviços prestados.

Porém, essas discussões fazem parte substancialmente das fundamentações dos ministros (de suas razões de decidir), especialmente dos que tiveram seus votos vencidos, não tendo qualquer impacto nos resultados finais dos julgamentos. De maneira geral, nem sequer foram objeto de debates efetivos do Tribunal como um todo, sendo encontradas muito mais em posicionamentos isolados dos ministros. Dessa forma, o que efetivamente se extrai dos resultados dos acórdãos é a unificação do regime jurídico aplicável à ECT, prestadora de serviço público.

Pouco importa se a estatal está distribuindo cartas ou se está prestando serviços bancários, todas as atividades que ela presta são tidas como serviços públicos (pelo que acabam sendo abarcadas pelos privilégios da estatal). Assim como também parece ter pouca relevância o fato de cerca de $25 \%$ dos serviços postais nas áreas de maior concentração populacional ser prestado através de agências franqueadas, escolhidas sem procedimento licitatório anterior à celebração dos contratos com a ECT, e de atuarem no setor aproximadamente 15.000 empresas privadas de distribuição de serviços postais. Nesse sentido, pode-se afirmar que a jurisprudência que unifica o regime jurídico aplicável à ECT (como serviço público) acaba em grande medida desconsiderando a complexidade dos serviços da rede postal e os diferentes agentes econômicos que atuam no setor. Tem-se aplicado um mesmo regime jurídico, desconsiderando-se que o núcleo material dos serviços postais é distinto. 


\section{V.2.3.2. Necessidade de avaliação da função dos privilégios postais e impacto sobre a competição no setor}

Da análise das decisões do STF resta claro que o ponto central dos debates sobre a possibilidade de conferir-se ou não à ECT a impenhorabilidade de seus bens e a imunidade tributária gravita em torno de saber se ela presta serviço público. Os ministros demonstram conceber um regime jurídico privilegiado à estatal pela natureza dos serviços que presta. Dada sua relevância para a sociedade, a ECT deve receber um tratamento diferenciado, preservando-se sua capacidade de seguir atuando como um dos grandes prestadores do mercado postal.

No entanto, a partir do momento em que a discussão parece voltar-se mais ao objetivo de preservar a empresa, o debate mais específico sobre a função pela qual o ordenamento jurídico confere a alguns entes a prerrogativa de se valer da impenhorabilidade de seus bens e da imunidade tributária parece ficar num plano secundário nas discussões entre os ministros.

Para proceder a essa análise, importante comentar dois ângulos jurídicos distintos que podem ser vislumbrados sobre o domínio de bens pelo ente personificado Estado, estruturados por Floriano de Azevedo Marques Neto em sua tese de livre-docência, posteriormente publicada ${ }^{175}$. Segundo o autor ${ }^{176}$, as teorias sobre a natureza jurídica dos bens públicos oscilam entre duas dimensões, que por vezes se complementam: de um lado a concepção subjetiva e de outro lado a relação funcional.

A primeira se preocupa em definir a quem cabem os bens existentes dentro do território, a partir de uma relação de titularidade, de domínio do bem. Por essa concepção, prevalecente no Código Civil, importa saber qual pessoa jurídica de direito público interno possui relação jurídica de propriedade sobre a coisa pública. Nessa perspectiva, são bens públicos os bens cujo domínio a legislação confere às pessoas jurídicas de direito público, e qualquer bem pertencente à titularidade privada (que não seja objeto de uma relação dominial de ente público) será privado.

\footnotetext{
${ }^{175}$ A tese, defendida na USP no ano de 2008, denomina-se $O$ regime jurídico das utilidades públicas: função social e exploração econômica dos bens públicos. Posteriormente, foi publicada com o título Bens públicos: função social e exploração econômica - $O$ regime jurídico das utilidades públicas.

${ }^{176}$ Cf. Floriano de Azevedo Marques Neto. Bens públicos: função social e exploração econômica - O regime jurídico das utilidades públicas, p. 102. Especificamente sobre o critério civilista (subjetivo) e sua crítica, ver p. 104-116. Sobre o critério funcionalista (objetivo), ver p. 117-121.
} 
A segunda, por sua vez, prevalecente entre os administrativistas, centra-se em saber para que finalidade o bem está sendo empregado, qual é a utilidade que o bem tem para a coletividade. Por essa perspectiva, são públicos os bens empregados no cumprimento de finalidades públicas, pouco importando saber quem é o titular do domínio do bem. Neste caso, para ser enquadrado como público o bem deve preencher requisitos de "essencialidade" e "indispensabilidade" para o exercício de uma função de interesse geral atribuída ao Estado.

Adotada a classificação de Floriano de Azevedo Marques Neto, pela concepção funcionalista, são três os requisitos a serem preenchidos para que um bem seja considerado público: (a) "a utilidade do bem deve corresponder a uma atividade cometida ao poder público por lei ou pela Constituição ou então cujas características tornem imperativo que ela seja realizada pelo Estado"; (b) "o bem deve ser essencial para aquela atividade, de modo a que dele não se possa prescindir sem prejuízo do exercício desta função pública"; e (c) "ainda que a necessidade recaia não sobre um bem individualizado mas sobre um determinado gênero de bens, aquele bem específico deve ser, ao menos naquelas circunstâncias, insubstituível ou, se substituído por outro equivalente, a este bem substituinte será transferida automaticamente a natureza de bem público" ${ }^{„ 177}$.

Partindo dessas concepções, o autor afirma que o ente da Administração Pública que melhor ilustra a influência do critério funcionalista são as empresas estatais (sociedades de economia mista e empresas públicas) ${ }^{178}$. Por serem constituídas sob regime de direito privado e não constarem do artigo 41 do Código Civil como pessoas jurídicas de direito público interno ${ }^{179}$, os bens das empresas estatais não são à luz do critério subjetivo (civilista) bens públicos. No entanto, segundo o autor, “...tanto a doutrina quanto a jurisprudência vêm construindo ao longo do tempo diversos argumentos para considerar os bens de empresas estatais, ou parte deles, como bens públicos (v.g., submetidos total ou

\footnotetext{
${ }^{177}$ Floriano de Azevedo Marques Neto. Bens Públicos: função social e exploração econômica - O regime jurídico das utilidades públicas, p. 120-121.

${ }^{178}$ Floriano de Azevedo Marques Neto. Bens Públicos: função social e exploração econômica - O regime jurídico das utilidades públicas, p. 160.

179 “Art. 41. São pessoas jurídicas de direito público interno: I - a União; II - os Estados, o Distrito Federal e os Territórios; III - os Municípios; IV - as autarquias, inclusive as associações públicas; (Redação dada pela Lei n. ${ }^{\circ}$ 11.107, de 2005); V - as demais entidades de caráter público criadas por lei. Parágrafo único. Salvo disposição em contrário, as pessoas jurídicas de direito público, a que se tenha dado estrutura de direito privado, regem-se, no que couber, quanto ao seu funcionamento, pelas normas deste Código".
} 
parcialmente a um regime de direito público), no mais das vezes a partir de um critério funcionalista" $" 180$.

Neste sentido, no julgamento conjunto do RE n. ${ }^{\circ}$ 220.906-9/DF, RE n. ${ }^{\circ}$ 225.0110/MG, RE n. ${ }^{\circ}$ 229.696-7/PE, RE n. ${ }^{\circ}$ 230.072-3/RS e RE n. ${ }^{\circ}$ 230.051-6/SP, o ministro Maurício Corrêa, relator, que proferiu o voto condutor da tese vencedora no STF, chamou atenção para o fato de que os bens da ECT são impenhoráveis por pertencerem à entidade estatal mantenedora. Pelo fato de o orçamento da estatal ser aprovado pelo Ministério do Planejamento e Orçamento e sua receita ser constituída de subsídio do Tesouro Nacional, seus bens, rendas e serviços, em seu entender, não devem poder se submeter à penhora. Seguindo essa linha decisória, o ministro Nelson Jobim chamou atenção para o fato de os bens da ECT serem afetados ao serviço público, essa seria a pedra de toque da questão, o fato de eles serem "bens do patrimônio administrativo"181.

O entendimento que prevaleceu nesse julgamento conjunto, portanto, ao sujeitar os bens da ECT ao regime de direito público (impenhorabilidade em processo de execução), por força da sua destinação geral ao serviço público, torna, por um critério funcionalista, os bens da ECT bens públicos, a despeito de assim não poderem ser considerados em sentido próprio (civilista).

O problema dessa linha de entendimento é que a partir dela a impenhorabilidade recai sobre todo o patrimônio da estatal, independentemente dos serviços que presta e do fato de ela, por exemplo, prestá-los ou não em regime de competição com outros agentes econômicos. Se, tal como demonstra toda a argumentação dos ministros, a razão da "publicização" dos bens é seu emprego direto numa atividade de interesse público, caberia fazer uma diferenciação entre os bens da "entidade estatal mantenedora", nos dizeres do ministro Maurício Corrêa, e os bens do "patrimônio administrativo", tomando por base o voto do ministro Nelson Jobim.

\footnotetext{
${ }^{180}$ Floriano de Azevedo Marques Neto. Bens Públicos: função social e exploração econômica - O regime jurídico das utilidades públicas, p. 161.

${ }^{181} \mathrm{RE} \mathrm{n.}^{\circ} 220.906-9 / \mathrm{DF}$, p. 473.
} 
De certo modo essa questão foi levantada pelo ministro Sepúlveda Pertence (voto vencido), condutor de uma linha decisória intermediária ${ }^{182}$ no julgamento conjunto, de acordo com a qual haveria um problema no decreto-lei n. ${ }^{\circ} 509$ por ele ter conferido à ECT o privilégio da impenhorabilidade universal de seu patrimônio e não apenas dos bens afetados ao serviço público. A questão de saber o que pode ser englobado dentro do conceito "serviço postal e telegráfico", ou seja, quais serviços não podem ser caracterizados como serviços públicos, no entanto, não foi explorada pelo ministro.

Diante disso, claramente nota-se que há uma preocupação secundária por parte do STF em verificar quais os bens da empresa estatal ECT estão empregados diretamente no cumprimento de sua atividade fim de interesse público. Se, no entanto, como vimos, para serem enquadrados como públicos por um critério funcional e, pois, submeterem-se a um regime total ou parcialmente público, os bens devem ser essenciais e indispensáveis para o desempenho das funções públicas, o enquadramento genérico dos bens da ECT como públicos é equívoco. Isso porque o raciocínio desenvolvido pelo STF acaba por recair no entendimento segundo o qual como a ECT foi criada para cumprir objetivos de interesse geral, todos os bens do seu patrimônio são públicos, independentemente de sua diversidade e de serem ou não afetos ao serviço postal e telegráfico ou a ele serem ancilares, ou ainda de sua utilização ser mais compatível com a exploração econômica desenvolvida pela empresa estatal.

Deveras, o julgamento do STF parece deixar em aberto a questão de saber se há efetivamente preocupação por parte dos ministros em resguardar os bens e serviços públicos ou se sua preocupação volta-se em maior medida a preservar a empresa pública ECT, independentemente das atividades que presta e dos bens a elas afetados. Retomando os requisitos que Floriano de Azevedo Marques Neto entende que devem ser preenchidos para que um bem seja considerado público e tomando por base o setor postal, cabe indagar: todas as atividades que a ECT presta, nas quais utiliza seus bens, foram cometidas ao poder público (por lei ou pela Constituição) ou têm características que tornam imperativo que sejam realizadas pelo Estado? Quais são os bens essenciais para a realização dessas atividades? Todos os caminhões da ECT, por exemplo, são usados para essas atividades

\footnotetext{
${ }^{182}$ Conforme item II.1, as argumentações semelhantes dos ministros foram agrupadas em linhas decisórias. Em relação a esse julgamento conjunto, entendeu-se que essa linha é intermediária por não adotar a impenhorabilidade ou penhorabilidade total de bens, mas sim a impenhorabilidade parcial, dos bens afetos ao serviço postal. Em anexo, encontram-se especificados os argumentos de cada uma delas.
} 
cometidas ao poder público? Em que medida os bens da ECT são insubstituíveis em relação a todas as atividades que a estatal presta?

E para além dessas questões, do ponto de vista das demais empresas que atuam no mercado postal, é legítimo privilegiar a ECT, impossibilitando a submissão de seus bens, rendas e serviços à penhora, independentemente das atividades prestadas e de serem "essenciais" e "indispensáveis" para a coletividade? Sob esse ponto de vista, em que medida a impenhorabilidade genérica dos bens da estatal se coaduna com o entendimento de que o STF excluiu impressos e encomendas do regime de serviço público (análise que será feita especialmente no item V.3.3.4)? Certamente a reflexão sobre questões como essas enriqueceria o debate entre os ministros e a reflexão mais ampla sobre o setor postal.

De maneira semelhante, a função de se conferir à ECT a imunidade tributária ficou num plano secundário nas discussões entre os ministros. Em termos gerais, o STF entendeu que a distinção entre empresas públicas prestadoras de serviço público e empresas públicas exploradoras de atividade econômica não se limita ao art. 173 da Constituição, alcançando, no caso das prestadoras de serviço público, o art. 150, VI, que veda à União, Estados, Distrito Federal e Municípios instituir impostos em determinadas hipóteses, especificadas em suas alíneas. A este fenômeno os tributaristas dão o nome de "imunidade tributária".

Seguindo a definição proposta por Roque Antonio Carrazza, “...as normas constitucionais que tratam das imunidades tributárias fixam a incompetência das pessoas políticas para fazerem incidir a tributação sobre determinadas pessoas, seja pela natureza jurídica que estas têm, seja porque realizam certos fatos, seja, ainda, por estarem relacionadas com dados bens ou situações" ${ }^{\prime 183}$. A relação de casos de imunidade tributária, segundo o citado tributarista, está toda definida na própria Constituição ${ }^{184}$, especificamente nas alíneas do citado inciso VI, que se refere à imunidade das pessoas políticas ("a"), dos templos de qualquer culto ("b"), dos partidos políticos e suas fundações, das entidades sindicais dos trabalhadores e das instituições de educação e de assistência social ("c") e aos livros, jornais, periódicos e o papel destinado a sua impressão (“d”).

\footnotetext{
${ }^{183}$ Roque Antonio Carrazza, Curso de direito constitucional tributário, p. 678.

${ }^{184}$ Roque Antonio Carrazza, Curso de direito constitucional tributário, p. 681 e 683.
} 
Além dessas imunidades gerais, que alcançam todos ou vários impostos, o autor chama atenção para a existência de imunidades específicas, que dizem respeito a um único imposto, previstas no art. 153, §2º II (revogado pela Emenda Constitucional n. ${ }^{\circ}$ 20/1998,

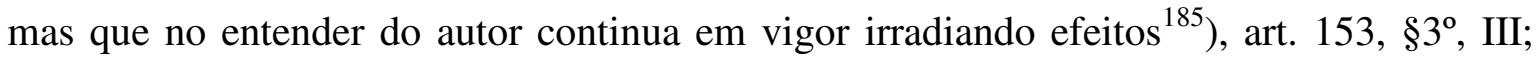

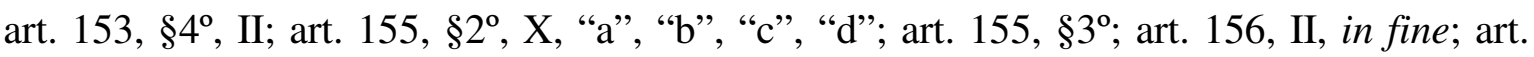
$156, \S 2^{\circ}$, I; art. $184, \S 5^{\circ}$; art. $195, \S 7^{\circ}$, todos da Constituição ${ }^{186}$.

Foge ao escopo do presente estudo analisar o instituto da imunidade tributária a partir de todas as suas hipóteses de incidência, assim como também não se propõe a estudar com profundidade o fenômeno da imunidade tributária. É importante, no entanto, tecer alguns comentários sobre o instituto, especialmente voltados à alínea "a" do art. 150, VI, da Constituição, que a corrente majoritária do STF entende aplicável à ECT, afastada a excludente do $\S 3^{\circ}$.

Todas as hipóteses previstas no art. 150, inciso VI, prescrevem a incompetência das entidades tributantes para onerar certas pessoas jurídicas. Algumas por sua natureza jurídica, como as pessoas políticas, e algumas porque relacionadas a determinados fatos, bens ou situações. Em termos gerais, a previsão constitucional tem por finalidade proteger o princípio federativo no Brasil, a livre manifestação da religiosidade das pessoas num Estado laico, a proteção do pluralismo partidário, a proteção da liberdade sindical, a difusão do ensino e da cultura, a difusão de atividades de assistência social, a livre manifestação do pensamento e o acesso à informação.

Especificamente no caso da alínea "a" "187, a imunidade tributária beneficia pessoas políticas (União, Estados, Municípios e Distrito Federal) em decorrência do princípio federativo - se uma pessoa pudesse instituir impostos de outra acabaria por interferir em sua autonomia enquanto ente federativo do Estado brasileiro (CF, art. $18 \mathrm{c} / \mathrm{c}$ art. 60, $\left.\S 4^{\circ}, \mathrm{I}\right)$ - e do princípio da isonomia, que predica igualdade entre as pessoas políticas, inexistente entre elas qualquer hierarquia e, pois, a possibilidade de um estado de sujeição de quem é tributado em relação a quem o tributa. Subjacente a essa hipótese está o descabimento de uma pessoa política, ao exigir impostos de outra, criar-lhe dificuldades de funcionamento.

\footnotetext{
${ }^{185}$ A esse respeito, ver Roque Antonio Carrazza, Curso de direito constitucional tributário, p. 759.

${ }^{186}$ A esse respeito, ver Roque Antonio Carrazza, Curso de direito constitucional tributário, p. 758-801.

${ }^{187}$ Cf. Roque Antonio Carrazza, Curso de direito constitucional tributário, p. 689-690.
} 
Esse dispositivo, no entanto, deve ser lido junto com o $\S 3^{\circ}$ do art. 150, que restringe a imunidade tributária ao patrimônio, renda e serviços não “...relacionados com exploração de atividades econômicas regidas pelas normas aplicáveis a empreendimentos privados, ou em que haja contraprestação ou pagamento de preços ou tarifas pelo usuário...". Esse artigo prescreve, assim, que sempre que uma pessoa política desempenhar atividades econômicas, não lhe é aplicável a imunidade tributária, sujeitando-se aos impostos pertinentes. O princípio da imunidade tributária recíproca, portanto, alcança pessoas políticas tão somente quando elas desempenham suas funções típicas, as atividades públicas propriamente ditas.

Por outro lado, o $\S 2^{\circ}$ do art. 150 estende a imunidade tributária “...às autarquias $e$ às fundações instituídas e mantidas pelo Poder Público, no que se refere ao patrimônio, à renda e aos serviços, vinculados a suas finalidades essenciais ou às delas decorrentes", alcance que se tem entendido - tanto doutrinariamente ${ }^{188}$ quanto na esfera judicial, especialmente no STF - aplicável também às empresas estatais, enquanto delegatárias de serviços públicos ou enquanto exercem atos de polícia. É dizer, tem-se equiparado as empresas estatais aos beneficiários da imunidade, de modo a criar em seu favor direito subjetivo de que o poder público se abstenha de cobrar-lhes certos tributos.

Segundo Roque Antonio Carrazza ${ }^{189}$, a extensão da imunidade tributária às estatais deve-se ao fato de que, na medida em que a empresa estatal não determina livremente o valor da contraprestação pelo serviço prestado ou pelo ato de polícia praticado, que é regulado por lei (no caso das taxas) ou por ato do poder Executivo (no caso dos preços ou tarifas), esse valor não é adequado, eis que não há equivalência entre o custo da atuação estatal e o valor desembolsado pelo usuário em razão dela. O autor assinala ainda que, mesmo que lhe seja economicamente desvantajoso, a estatal não pode negar-se a prestar o serviço público ou o ato de polícia; trata-se de ônus e não de faculdade.

${ }^{188}$ Cf. Roque Antonio Carrazza, Curso de direito constitucional tributário, p. 694-697.
${ }^{189}$ Cf. Roque Antonio Carrazza, Curso de direito constitucional tributário, p. 695. 
Essa concepção do tributarista claramente parte do objetivo de proteger os serviços prestados pela ECT, é dizer, a atuação da estatal, não se relacionando propriamente às finalidades que a alínea "a" busca proteger, quais sejam, o princípio federativo e correspondente autonomia dos entes políticos, e a igualdade entre as pessoas políticas. Neste sentido, a análise do autor não se atém ao fato de ser a estatal federal, estadual ou municipal, por exemplo. Partindo de sua concepção, embora as regras imunizantes estejam sendo estendidas às estatais com base na alínea "a", o que se busca proteger nesse caso é o funcionamento da ECT, para que ela, enquanto empresa pública, siga agindo em nome do Estado para a consecução de objetivos públicos, a prestação de serviços públicos, com o que afasta-se a excludente do $\S 3^{\circ}$.

Nesta linha também gravita o debate do STF acerca da imunidade tributária conferida à ECT. Em todas as decisões do Tribunal analisadas o argumento central utilizado pelos ministros para a extensão das regras imunizantes à estatal é o fato de ela ser prestadora de serviço público. Neste sentido, foi a decisão do RE n. ${ }^{\circ}$ 407.099-5/RS, que serviu de precedente para os julgamentos do RE n. ${ }^{\circ}$ 356.122-7/RS, do RE n. 354.897 2/RS, do RE n. ${ }^{\circ}$ 398.630-9/SP, do RE n. ${ }^{\circ}$ 428.821-4/SP, do RE n. ${ }^{\circ}$ 437.889-2/RS, do Ag. Reg. no RE n. ${ }^{\circ}$ 357.291-1/PR, do RE n. ${ }^{\circ}$ 424.227-3/SC e do RE n. ${ }^{\circ}$ 364.202-2/RS.

O entendimento pacífico do STF também pode ser verificado no julgamento dos

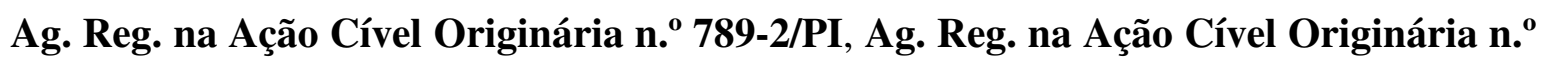
814-7/PR, Ag. Reg. na Ação Cível Originária n. ${ }^{o}$ 765-1/RJ, Ag. Reg. na Ação Cível Originária n. ${ }^{\circ}$ 811-5/DF, Ag. Reg. na Tutela Antecipada na Ação Cível Originária n. ${ }^{\circ}$ 912-8/MS, Ag. Reg. na Medida Cautelar na Ação Cível Originária n. ${ }^{\circ}$ 1.095-6/GO, Ação Cível Originária n. 959-4/RN, Ag. Reg. no Agravo de Instrumento n. ${ }^{\circ}$ 718.6461/SP, Ag. Reg. no Agravo de Instrumento n. ${ }^{0}$ 690.242-0/SP, Ação Cível Originária n. ${ }^{\circ}$ 765-1/RJ, Ag. Reg. no Agravo de Instrumento n. ${ }^{\circ}$ 748.076/MG, Ag. Reg. no Recurso Extraordinário n. ${ }^{\circ}$ 552.736/RS, Ação Cível Originária n. ${ }^{\circ}$ 789/PI e Ag. Reg. na Ação Cível Originária n. ${ }^{\circ}$ 819/SE.

O único julgamento que apresentou uma linha de argumentação um pouco diferente foi o Ag. Reg. no Agravo de Instrumento n. ${ }^{\circ}$ 518.325/RS, ocorrido em 06 de abril de 2010. No caso, a ECT não figurava como parte, tendo surgido no julgamento porque o município de São Leopoldo questionava decisão do ministro Joaquim Barbosa que havia negado seguimento a agravo de instrumento, sustentando que a imunidade tributária 
recíproca só é aplicável ao contribuinte de fato e que deveria ser concedido o mesmo tratamento conferido à ECT.

No julgamento, o ministro Joaquim Barbosa (voto condutor) fundamentou seu voto contrário ao município nas seguintes razões $^{190}$ : (i) o alcance da imunidade tributária recíproca é definido pela sua vocação para servir como salvaguarda do pacto federativo, para evitar pressões políticas entre entes federativos ou para desonerar atividades desprovidas de presunção de riqueza; (ii) a imunidade recíproca opera como um instrumento de proteção de instrumentalidades estatais, não podendo ter como efeito jurídico colateral o desequilíbrio das condições de concorrência econômica, nem o benefício de entidade particular, voltada à exploração econômica e lucrativa de qualquer objeto; (iii) a função da imunidade tributária não é permitir ao ente federado pura e simplesmente contratar serviços onerosos a preços inferiores aos praticados pelo mercado em geral; e (iv) os precedentes invocados pelo município não seriam aplicáveis ao caso, pois reconhecer a imunidade da ECT quando presta seus serviços não significa reconhecer a imunidade do ente público quando ele adquire bens em operações onerosas e que têm por objetivo o lucro.

Neste caso, em que a ECT não figura como parte e, pois, a referência à estatal é apenas indireta, o voto condutor do ministro Joaquim Barbosa, acompanhado pelos demais ministros sem quaisquer reservas, seguiu uma argumentação mais alinhada aos objetivos perseguidos pela alínea "a", embora também tenha sido abordada a questão da extensão das regras imunizantes em razão dos serviços prestados.

Regra geral, portanto, as imunidades vêm sendo conferidas pelo STF à ECT pelo fato de ser prestadora de serviço público. No entanto, a partir do momento em que se questiona o enquadramento genérico das atividades prestadas pela ECT como serviços públicos, a partir da dicotomia serviços públicos versus atividades econômicas, passa a ser questionável a incidência das regras imunizantes a todo "patrimônio, renda e serviços" da ECT. Deveras, quando uma empresa estatal desempenha atividades econômicas, deixa de ser pessoa beneficiada pela imunidade tributária, devendo se submeter aos mesmos tributos que alcançam as empresas privadas em geral, conforme expressamente prescreve o art. $173, \S 2^{\circ}$, segundo o qual “As empresas públicas e as sociedades de economia mista não poderão gozar de privilégios fiscais não extensivos às do setor privado", dispositivo que claramente visa a impedir concorrência desleal. Uma vez competindo com empresas

${ }^{190}$ AI n. ${ }^{\circ} 518.325-\mathrm{AgR} / \mathrm{RS}$, p. $1689-1692$. 
privadas em livre mercado, se as empresas estatais receberem um tratamento tributário especial, seus produtos ou serviços, livres dos custos da tributação, tenderiam a ser mais baratos do que os das empresas privadas, em detrimento delas.

Diante da restrição do alcance da imunidade tributária às pessoas políticas e entes que lhe são equiparados tão somente quando desempenham suas funções típicas, as atividades públicas propriamente ditas, faz sentido questionar se toda a rede postal é ou deve ser imune à tributação, ainda que de maneira geral o STF apresente um enquadramento genérico das atividades da ECT como públicas e a partir disso imponha o dever da abstenção de se tributar todo seu "patrimônio, renda e serviços".

Ao considerarmos, no entanto, que nem todas as atividades da estatal são típicas, propriamente públicas, e "monopolizadas", o enquadramento genérico da imunidade tributária à ECT é equívoco, pois privilegia a ECT em detrimento das empresas privadas que com ela competem no mercado postal. Existente essa área de prestação livre, em regime de mercado, nela a ECT não age em nome do Estado para a consecução de objetivos públicos, do bem comum, mas sim em competição com qualquer outra empresa que atue no mercado postal.

Essa discussão surgiu ao longo de alguns julgamentos do STF. Em 05 de outubro de 2006, o Tribunal julgou três agravos regimentais (Ag. Reg. na Ação Cível Originária n. 789-2/PI, o Ag. Reg. na Ação Cível Originária n. ${ }^{\circ}$ 814-7/PR e o Ag. Reg. na Ação

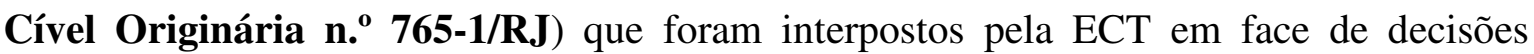
monocráticas em que o ministro Marco Aurélio, dissonante do entendimento pacífico do STF, havia denegado a concessão de tutela antecipada que impediria que os Estados do Piauí, Paraná e Rio de Janeiro, respectivamente, exigissem da ECT o recolhimento de valores a título de Imposto sobre a Propriedade de Veículos Automotores (IPVA). Nestes casos, o ministro Marco Aurélio, em seu voto divergente (minoritário), partiu do entendimento segundo o qual a ECT presta atividades econômicas, além de, como ente integrante da Administração Indireta, ter personalidade jurídica própria e natureza privada.

Numa linha intermediária podem-se englobar os posicionamentos dos ministros Ricardo Lewandowski e Joaquim Barbosa. Votaram em sentidos diversos, mas ambos chamaram atenção para a diversidade da rede postal. O primeiro acompanhou o voto do ministro Marco Aurélio por considerar que (i) a ECT hoje compete com a iniciativa privada no tocante à prestação de alguns serviços; (ii) ela exerce uma série de serviços que não são estritamente públicos (banco postal, dinheiro fácil, importa fácil); e (iii) deveria 
haver uma preocupação com as agências franqueadas, examinando-se se a isenção do IPVA se estenderia também às centenas de franqueadas do correio que, segundo ele, em geral exercem vários serviços em que competem efetivamente com as empresas privadas, razão pela qual teriam com a isenção uma condição privilegiada ${ }^{191}$.

O ministro Joaquim Barbosa (voto vencedor) foi quem iniciou a divergência em relação ao voto do ministro Marco Aurélio, mas em seu voto considerou que a ECT é empresa pública que executa ao menos um conjunto de atividades de caráter público. Segundo ele, a estatal executa serviços que inequivocamente não são públicos nem se inseririam na categoria serviços postais, como a atividade bancária Banco Postal ${ }^{192}$. Porém, ele entendeu que a ponderação deveria ser feita por ocasião do respectivo julgamento de mérito, tendo em vista que segundo a ECT “...os veículos cuja propriedade é tributada com o IPVA são usados para serviços de coleta, remessa ou entrega de correspondência, documentos, objetos, bens e valores" $" 193$.

No entanto, a linha decisória que prevaleceu no julgamento desses agravos entendeu que a prestação dos serviços postais é de serviço público, sem fazer qualquer ponderação em relação às diversas atividades por ele englobadas. Foi a posição dos ministros Eros Grau (que fundamenta seu voto no texto da Constituição: "Não tenho dúvida: a Constituição estabelece que o serviço postal é um monopólio estatal" ${ }^{\text {"194 }}$ ), Carlos Britto (em razão de ser o serviço postal uma atividade estratégica e genuinamente estatal, própria da integração e coesão nacional; e pelo fato de o reconhecimento da imunidade diminuir os custos da manutenção da empresa com sua frota de veículos) ${ }^{195}$ e de Cezar Peluso (que preferiu não antecipar juízo de valor em definitivo, aguardando o julgamento da ADPF n. ${ }^{\text {46-7/DF }}{ }^{196}$.

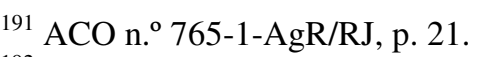

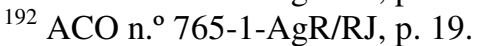

${ }^{193}$ ACO n. ${ }^{\circ}$ 765-1-AgR/RJ, p. 19-20.

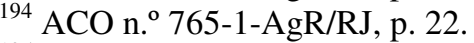

${ }^{195}$ ACO n. ${ }^{\circ} 765-1-A g R / R J, p . ~ 23-24$.

${ }^{196}$ ACO n. ${ }^{\text {o }}$ 765-1-AgR/RJ, p. 26.
} 
Seguindo esse entendimento do ministro Cezar Peluso, em 26 de abril de 2007, quando do julgamento do Ag. Reg. na Ação Cível Originária n. ${ }^{\circ}$ 811-5/DF, o ministro Gilmar Mendes, relator, tendo de se manifestar sobre as alegações da agravante de que algumas atividades da ECT teriam nítida natureza econômica (como o Banco Postal e o Sedex), ressaltava que a natureza jurídica e a amplitude do conceito dos serviços postais prestados pela ECT estavam em debate na ADPF n. ${ }^{\circ} 46-7$, sendo conveniente deixar a sua análise para o momento da apreciação do mérito dessa ação ${ }^{197}$.

Em 2009 mais uma vez os debates surgiram, dessa vez tendo por base o julgamento da Ação Cível Originária n. ${ }^{\mathbf{7}}$ 765-1/RJ, em que a ECT pedia que o STF se pronunciasse pela inexigibilidade de cobrança pelo Estado do Rio de Janeiro do IPVA, e afastasse as sanções decorrentes do não-pagamento do tributo. Fundamentava seu pedido no fato de desempenhar atividades típicas de serviço público obrigatório e exclusivo. O Estado do Rio de Janeiro contestou a inicial sustentando a ausência de imunidade da autora, tendo em conta tratar-se de exploração de atividade econômica pelo Estado. A ação foi julgada procedente, por maioria de votos, vencidos os ministros Marco Aurélio e Ricardo Lewandowski, que a julgavam improcedente, e o ministro Joaquim Barbosa, que a julgava improcedente em parte. Podem-se verificar nos votos três linhas decisórias.

A primeira linha decisória relaciona-se aos votos dos ministros Marco Aurélio e Ricardo Lewandowski. O primeiro reproduziu seu entendimento, na mesma linha dos seus pronunciamentos anteriores ${ }^{198}$. O segundo acolheu os fundamentos do voto do ministro Marco Aurélio (a imunidade do art. 150, II, "a" se aplicaria essencialmente a pessoas jurídicas de direito público; e em razão da previsão do art. $173, \S 2^{\circ}$ ), manifestando uma clara preocupação em relação à extensão da imunidade a empresas que exercem práticas de natureza tipicamente comercial $^{199}$.

Nesse sentido, partia de dois pontos de análise: (i) parte das atividades exercidas pela ECT corresponderia efetivamente a serviço público, mas do seu ponto de vista, existiria uma outra parte, bastante considerável, que visaria apenas o lucro, tal como se fosse uma empresa privada; e (ii) o serviço da ECT é franqueado. Segundo ele, existiriam quase 1.500 franquias da ECT distribuídas por cerca de 500 municípios em todo o Brasil, e lhe causava perplexidade o fato de o STF estar concedendo imunidade a elas. Com isso, o STF estaria terceirizando a imunidade constitucional para acobertar uma atividade de

${ }^{197}$ ACO n. ${ }^{\circ} 811-\mathrm{AgR} / \mathrm{DF}$, p. 26.

${ }^{198}$ ACO n. ${ }^{\circ} 765-1 /$ RJ, p. 4.

${ }^{199}$ ACO n. ${ }^{\circ} 765-1 /$ RJ, p. 15-16. 
caráter nitidamente privado e comercial: "[t]odos os seus veículos estão isentos de IPVA, $e$ suas atividades estariam isentas dos impostos dos demais entes federais. Isso me causa perplexidade..."200. Para o ministro, as franqueadas não estariam compreendidas nessa imunidade.

A segunda linha decisória relaciona-se ao voto do ministro Joaquim Barbosa. Segundo ele, é necessário considerar o que chama de natureza anfibiológica da ECT, pelo fato de ela exercer de um lado atividades típicas do Estado e de outro atividades econômicas (dizia ele: "Ela tem, inclusive, um banco, não é?",201). Por essa razão, ele considerava necessário que o ente tributante fizesse essa distinção no momento de exercer o seu poder tributário. Julgou com isso parcialmente procedente a ação, por abrir a “...possibilidade de o ente tributante fazer essa triagem entre o que é afetado ao serviço eminentemente postal e o que é atividade econômica" ${ }^{\text {202 }}$. Segundo ele, ao atuar como empresa privada, a ECT deveria se submeter às regras de direito tributário ${ }^{203}$.

A terceira linha decisória, majoritária, foi conduzida pelo voto do ministro Eros Grau, segundo o qual o art. 173 claramente se aplica única e exclusivamente a empresas estatais exploradoras de atividade econômica, e segundo ele “...a Empresa Brasileira de Correios e Telégrafos é uma empresa prestadora de serviço público. Está previsto no art. 21 da Constituição"204. Quanto à extensão do privilégio às franquias, o ministro entendeu que elas de forma alguma descaracterizam o serviço público. Segundo ele, em passagem já reproduzida nesta dissertação: "Se eu pensar na cidade de São Paulo (...) lá há uma empresa concessionária (...) chamava-se MTC, que tinha uma série de franqueados $e$ permitia a outras empresas a prestação do serviço (...). São como empresas franqueadas, sem que isso absolutamente descaracterize o serviço público que (...) é serviço público por definição constitucional..."205.

\footnotetext{
${ }^{200}$ ACO n. ${ }^{\circ} 765-1 /$ RJ, p. 19.

${ }^{201}$ ACO n. ${ }^{\circ} 765-1 /$ RJ, p. 23.

${ }^{202}$ ACO n. ${ }^{\circ} 765-1 /$ RJ, p. 25.

${ }^{203}$ ACO n. ${ }^{\circ} 765-1 /$ RJ, p. 26.

${ }^{204}$ ACO n. ${ }^{\text {o }}$ 765-1/RJ, p. 17-18.

${ }^{205}$ ACO n. ${ }^{\circ} 765-1 /$ RJ, p. 18.
} 
Em linha assemelhada são os votos dos ministros Carlos Ayres e Cezar Peluso. O primeiro chamava atenção para o fato de que quando uma empresa como a ECT obtém lucro, ela não faz do lucro um fim, pois ela o obtém para continuar prestando a atividade $^{206}$. O ministro Cezar Peluso, por sua vez, enfatizava não ser possível estabelecer a priori, nem empiricamente, nenhuma distinção sobre a propriedade dos bens porque se todos eles fossem subtraídos da empresa, ela não poderia desempenhar a prestação de serviço público que lhe foi atribuída ${ }^{207}$.

A partir do voto do ministro Ricardo Lewandowski, os ministros discutiram se a imunidade também se estenderia às agências franqueadas, mas o STF acabou não se pronunciando em relação ao tema, concluindo que não estava sendo discutido no caso. A partir do voto do ministro Joaquim Barbosa, os ministros também discutiram se seria possível discriminar para quais serviços a ECT utilizaria os veículos. A ministra Ellen Gracie ponderava que o IPVA é atribuído a débito de quem é proprietário do veículo (a ECT), não fazendo parte da hipótese de incidência tributária a forma como ela se utilizará do veículo ${ }^{208}$ (argumento mencionado anteriormente).

Também em 2010 a conferência de imunidade genérica à estatal foi questionada. Em 20 de abril, a Segunda Turma do STF julgou o Ag. Reg. no Recurso Extraordinário n. ${ }^{\circ}$ 443.648/RS, impetrado contra decisão do ministro Joaquim Barbosa, que havia entendido que não era possível deixar de aplicar a imunidade se o ente tributante não especificasse o modo pelo qual os serviços, a renda ou o patrimônio da ECT não estavam sendo aplicados na execução dos serviços públicos que justificavam a imunidade recíproca. Nas palavras do ministro, “...compete ao ente tributante identificar com precisão os critérios que descaracterizariam as atividades da autora como públicas, no caso concreto"209. O município de Porto Alegre sustentava que a ECT não poderia ser beneficiária da imunidade recíproca por ser entidade que desempenha atividade econômica insuscetível de receber benefícios não extensíveis à iniciativa privada (art. 173, CF). Nos termos do voto do ministro relator, a Segunda Turma do STF, em votação unânime, negou provimento ao agravo regimental.

\footnotetext{
${ }^{206}$ ACO n. ${ }^{\circ} 765-1 /$ RJ, p. 27-32.

${ }^{207}$ ACO n. ${ }^{\circ} 765-1 /$ RJ, p. 34.

${ }^{208}$ ACO n. ${ }^{\circ} 765-1 /$ RJ, p. 25.

${ }^{209}$ RE n. $^{\circ}$ 443.648-AgR/RS, p. 1369.
} 
O ministro Joaquim Barbosa fundamentou sua decisão nas seguintes razões ${ }^{210}$ : (i) o STF havia consolidado orientação segundo a qual a ECT é beneficiária da imunidade recíproca (art. 150, VI, "a" da CF); (ii) o ponto que segundo ele ainda estava pendente de definição relacionava-se à extensão da imunidade ao patrimônio, renda ou serviços estranhos à atividade principal da entidade, matéria que segundo ele seria enfrentada nos autos do RE n. ${ }^{\circ}$ 601.392; e (iii) no caso em análise, a parte agravante não fazia distinção entre as atividades protegidas pela imunidade e as atividades de exclusivo interesse privado-econômico, o que o afastava da decisão do RE. Segundo ele, questionava-se apenas a inaplicação total da imunidade recíproca à atividade postal, tese que já havia sido rechaçada pelo STF.

Em 04 de dezembro de 2009, foi publicado o julgamento da Repercussão Geral em Recurso Extraordinário n. ${ }^{\circ}$ 601.392/PR. Um recurso extraordinário havia sido interposto contra acórdão do Tribunal Regional Federal (TRF) da $4^{\mathrm{a}}$ Região, de acordo com o qual a imunidade tributária da qual a ECT era beneficiária restringia-se aos serviços tipicamente postais mencionados no art. $9^{\circ}$ da lei n. $.^{\circ} 6.538 / 78$, razão pela qual o município poderia cobrar Imposto sobre Serviços (ISS) relativamente aos serviços não abarcados pelo monopólio concedido pela União, que também são realizados por empresas da iniciativa privada. A ECT recorreu da decisão sustentando que (i) a imunidade deve alcançar todas as atividades postais realizadas pela empresa; (ii) executa serviços próprios da União e correlatos, de modo permanente e sem fins lucrativos, arcando com despesas não cobertas pelo preço cobrado nas postagens; (iii) há risco de prejuízo à prestação dos serviços postais, caso haja a obrigatoriedade de recolhimento do ISS; ressaltava estarem em jogo milhões e milhões de reais. Nessa oportunidade, o Tribunal reconheceu a existência de repercussão geral da questão constitucional suscitada. Esse recurso extraordinário pende de julgamento final ${ }^{211}$.

Essa questão da conferência genérica de imunidade à estatal também surgiu quando do julgamento pelo Plenário do STF da Ação Cível Originária n. ${ }^{\circ}$ 789/PI, em $1^{\circ}$ de setembro de 2010, em que a ECT pediu que o Tribunal se pronunciasse no sentido da inexigibilidade, pelo Estado do Piauí, do IPVA e do afastamento de sanções decorrentes do não-pagamento do tributo, considerado o desempenho de atividades típicas de serviço público obrigatório e exclusivo. O Estado do Piauí contestou a inicial, sustentando a

\footnotetext{
${ }^{210}$ RE n. $^{\text {o } 443.648-A g R / R S, ~ p . ~ 1371-1372 . ~}$

${ }^{211}$ Última atualização da pesquisa em 20.12.2011.
} 
ausência de imunidade da autora, tendo em conta tratar-se de exploração de atividade econômica pelo Estado.

O ministro Marco Aurélio, relator, alinhado aos seus pronunciamentos anteriores, julgou improcedente o pedido formulado, reiterando os fundamentos que utilizou no julgamento da ACO n. ${ }^{\circ}$ 959-4/RN. Em sentido diverso, o ministro Dias Toffoli conduziu a corrente majoritária, pela procedência do pedido para declarar a inexistência, por parte da autora, do dever de recolhimento do IPVA relativo aos veículos de sua propriedade, restando definitiva a decisão de antecipação da tutela.

O ministro partiu da ideia segundo a qual a jurisprudência do STF está consolidada, pois desde o julgamento do RE n. ${ }^{\circ}$ 407.099/RS firmou-se no sentido de que a ECT, empresa pública prestadora de serviço público, é beneficiária da imunidade tributária recíproca. Chamou atenção para o fato de que no julgamento da ADPF n. ${ }^{\circ} 46$ confirmou-se que a ECT é prestadora de serviço público em regime de exclusividade, estando fora do regime de "monopólio" encomendas e impressos, e debateu-se a distinção das atividades exercidas pela autora que teriam nítida natureza econômica, a demandar certa ponderação quanto à espécie de patrimônio, renda e serviços protegidos pela imunidade recíproca.

No entanto, embora o ministro tenha interpretado que desse julgamento se extrai a necessidade de ponderação da aplicação das regras imunizantes, entendeu que no presente caso não havia óbice à integral aplicação do entendimento firmado no julgamento da ACO 765/RJ, anteriormente analisado. Segundo o ministro, nesta oportunidade o Tribunal manifestou-se no sentido de que no caso de imunidade tributária relativa ao IPVA, como este, não caberia fazer distinção entre os veículos afetados ao serviço eminentemente postal e o que seria de atividade econômica. Diante do caso concreto, ressaltou o ministro: “...entendo não haver necessidade de mudança de entendimento desta Corte, em especial quanto ao IPVA, pois, independentemente de estar ou não o veículo afetado ao serviço eminentemente postal, a ECT permanece como empresa pública constituída para a prestação dos serviços de que cuida o art. 21, X, da Constituição Federal, e, como assentado na jurisprudência específica desta Suprema Corte, faz jus à imunidade tributária prevista no art. 150, VI, 'a', e $\$ 2^{\circ}$, da Carta Magna”, 212.

${ }^{212}$ ACO n. ${ }^{\circ} 789 /$ PI, p. 10. 
Destacou o ministro que a questão retornaria à discussão do Plenário quando do julgamento do RE n. ${ }^{\circ}$ 601.392/PR, com repercussão geral conhecida, que versa sobre a definição da extensão da imunidade tributária ao patrimônio, renda ou serviços estranhos à atividade principal da ECT, mas aborda apenas o Imposto sobre Serviços (ISS), o que o diferencia essencialmente do presente caso. Ao final, o Tribunal, por maioria, julgou procedente a ação, vencido o ministro Marco Aurélio.

Essas razões de decidir do ministro Dias Toffoli foram por ele reafirmadas quando do julgamento pelo Plenário do STF do Ag. Reg. na Ação Cível Originária n. ${ }^{\circ}$ 819/SE, em 17 de novembro de 2011. O recurso foi interposto pelo Estado de Sergipe em face de decisão do ministro Menezes Direito em que ele julgou procedente o pedido de reconhecimento do gozo pela ECT da imunidade recíproca (CF, art. 150, VI, "a"). Fundamentalmente, o Estado de Sergipe buscava afastar a incidência da cobrança do IPVA, no âmbito daquele ente federativo. No mérito, alegava que a decisão deveria ser reformada por ter partido do pressuposto da prestação exclusiva de serviço público pela empresa, quando esta também desempenha atividades de conteúdo econômico não abrangidas pela imunidade. Ao final, o Tribunal por unanimidade negou provimento ao agravo regimental, sem quaisquer reservas.

Mais uma vez os debates sobre a extensão da aplicação das regras imunizantes surgiram, quando do julgamento da Repercussão Geral no Recurso Extraordinário n. ${ }^{\circ}$ 627.051/PE, em 26 de maio de 2011, pelo Plenário do STF. Neste caso, a ECT havia interposto recurso extraordinário questionando decisão do TRF da $5^{\mathrm{a}}$ Região, segundo a qual, por ser a ECT pessoa jurídica de direito privado, se sujeita às mesmas obrigações tributárias que as empresas privadas, razão pela qual deve incidir Imposto sobre Circulação de Mercadorias e Serviços (ICMS) sobre o transporte de mercadorias que realiza, por não estar protegida pela imunidade constitucional. Em seu favor, a ECT alegou violação ao disposto no art. 150, VI, "a" da CF, sustentando que, com base na jurisprudência do STF, a imunidade tributária que lhe é atribuída é geral e irrestrita, aplicável a todo e qualquer imposto estadual. Defendeu que a atividade de transporte de encomendas não pode ser alvo de incidência de ICMS, pois faz parte do ciclo que compõe a atividade postal. Neste sentido, para fins de fixação da imunidade tributária, não interessaria qual serviço está sendo prestado pela recorrente, pois todos os recursos obtidos pela ECT serão revertidos em favor do serviço postal, destinado à coletividade. Em preliminar de repercussão geral, procurou demonstrar a repercussão da matéria. 
O ministro Dias Toffoli, relator, manifestou-se pela existência de repercussão geral da questão constitucional suscitada, no que foi acompanhado pelos demais ministros. Chamou atenção para a necessidade de o Plenário do STF enfrentar definitivamente a questão relativa à imunidade recíproca no que diz respeito ao ICMS e à sua incidência nos serviços de transporte prestados pela ECT. Neste sentido, mencionou diversas decisões em que foram objeto de discussão no STF os limites da imunidade tributária deferida aos Correios. O ministro ainda ressaltou que a questão "...transcende os interesses das partes, com repercussão na esfera de direitos de todos os Estados da Federação, dada a natureza da empresa pública e dos serviços por ela prestados". Esse recurso extraordinário pende de julgamento final ${ }^{213}$.

No entanto, difícil saber se de fato o STF se pronunciará mais detidamente sobre essa questão da diferenciação dos serviços prestados pela ECT e, pois, das regras imunizantes, quando do julgamento da Repercussão Geral em Recurso Extraordinário n. ${ }^{\circ}$ 601.392/PR (tal como salientou o ministro Joaquim Barbosa ao julgar o Ag. Reg. no Recurso Extraordinário n. ${ }^{\circ}$ 443.648/RS, e o ministro Dias Toffoli ao julgar a Ação Cível

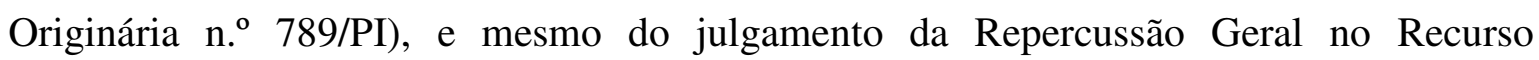
Extraordinário n. ${ }^{\circ}$ 627.051/PE.

Até o presente momento, o que se extrai dos resultados dos acórdãos é o enquadramento genérico das atividades prestadas pela ECT como serviços públicos e, pois, a incidência das regras imunizantes a todo "patrimônio, renda e serviços" da estatal. Deveras, as discussões a respeito do alcance da imunidade tributária e a restrição de sua incidência às atividades públicas propriamente ditas fazem parte substancialmente das fundamentações dos ministros (de suas razões de decidir), não tendo qualquer impacto nos resultados finais dos julgamentos. Em grande medida fizeram parte dos argumentos dos ministros que tiveram seus votos vencidos ou que assinalaram a importância de o STF futuramente discutir o tema. Diante disso, mais uma vez chama-se atenção para o fato de que o que efetivamente se extrai dos resultados dos acórdãos é a unificação do regime jurídico aplicável à ECT, prestadora de serviço público.

${ }^{213}$ Última atualização da pesquisa em 20.12.2011. 
Esse enquadramento genérico, no entanto, apresenta-se problemático na medida em que, como será analisado, especificamente no item V.3.3.4, na prática pode-se interpretar que o Tribunal excluiu impressos e encomendas não apenas do regime de exclusividade conferido à ECT, como também do regime de serviço público. Partindo desse entendimento, nessas áreas de prestação livre, seria indevido à ECT valer-se da imunidade tributária, devendo agir em igualdade de condições com quaisquer outras empresas que atuam no setor, sob pena de, não o fazendo, incidir nas prescrições dos artigos $150, \S^{\circ} \mathrm{e}$ $173, \S 2^{\circ}$ da Constituição.

Além disso, tendo em vista especialmente o fato de as regras imunizantes estarem sendo conferidas à estatal em grande medida para protegerem os serviços por ela prestados (a sua atuação no mercado postal), relacionando-se apenas indiretamente aos objetivos de se perseguir o princípio federativo e a igualdade entre as pessoas políticas, permanece ainda hoje a reflexão sobre a incidência (e extensão) da imunidade tributária às agências franqueadas.

Essa discussão surgiu quando do julgamento do Ag. Reg. na Ação Cautelar n.o 2.324-6/RS, em 12 de maio de 2009, que fora interposto contra decisão monocrática que havia indeferido a concessão de medida liminar para atribuição de efeito suspensivo a RE em que se discutia a incidência do Imposto sobre Serviços de Qualquer Natureza (ISSQN) sobre as atividades de franquia postal. A decisão agravada havia se apoiado em dois fundamentos: (i) a imunidade tributária recíproca não se aplicaria aos empreendimentos privados e àqueles em que haja contraprestação ou pagamento de preços ou tarifas pelo usuário $\left(\mathrm{CF}\right.$, art. $\left.150, \S 3^{\circ}\right)$, mas a atividade examinada, à qual se pleiteava imunidade, era desempenhada por entidade privada com intuito de exploração econômica; e (ii) o segundo fundamento relacionava-se a uma questão de ordem mais processual.

A agravante, Bela Vista Comércio de Produtos e Serviços Postais Ltda. alegava em seu favor: (i) superveniência de elemento novo, consistente no encurtamento do prazo para a realização da licitação que iria definir os novos franqueados da atividade postal; (ii) a orientação firmada pelo STF considerava taxativa a lista de serviços tributáveis com a incidência de ISS definida em normas gerais em matéria tributária; e (iii) registrou a existência de erro material na decisão. Pedia então a reforma da decisão para que fosse concedida a suspensão da exigibilidade do crédito tributário discutido nos autos do RE n. ${ }^{\circ}$ 505.220. O ministro relator Joaquim Barbosa acolheu o pedido para correção do erro 
material, tendo rejeitado as demais alegações. Foi acompanhado pela unanimidade da Turma sem quaisquer reservas.

A razão que o levou a assim decidir foi a seguinte: a decisão do Tribunal do Estado do Rio Grande do Sul tinha se fundamentado no exame da conformação do contrato de franquia, tendo concluído que o acordo entre as partes deixava claro tratar-se de agenciamento. Conforme o voto condutor do acórdão recorrido, explorado pelo ministro Joaquim Barbosa, a franquia não prestava serviços postais e/ou telemáticos, mas de agenciamento, “...colocando referidos no mercado mediante o recebimento de comissões da $E B C T^{, 214}$. Diante disso, o ministro entendeu que eventual conhecimento e provimento do RE dependeria (i) da descaracterização do contrato de franquia postal como agenciamento; e (ii) do reconhecimento de que franquia postal não é serviço previsto na lista de serviços anexa ao decreto-lei n. ${ }^{\circ} 406 / 1968$ ou da lei complementar n. ${ }^{\circ} 87$. Para ambos, segundo o ministro, seria necessário rever a interpretação da norma infraconstitucional, bem como reexaminar os fatos e provas, o que não poderia ser feito mediante agravo ${ }^{215}$.

Como visto anteriormente, o STF também se manifestou sobre o tema quando do julgamento da Ação Cível Originária n. 765-1/RJ, em 13 de maio de 2009, na qual, a partir do voto do ministro Ricardo Lewandowski, os ministros discutiram se a imunidade também se estenderia às agências franqueadas. Nesta ocasião, no entanto, o Tribunal acabou não se pronunciando em relação ao tema, concluindo que não estava sendo discutido no caso.

Por essas decisões, claramente nota-se que o tema da extensão das regras imunizantes às agências franqueadas ainda hoje foi pouco debatido pelo STF. Foi tratado somente quando do julgamento pela Segunda Turma do STF do Ag. Reg. na Ação Cautelar n. ${ }^{\circ}$ 2.324-6/RS, e mesmo nesse caso o Tribunal não se manifestou de forma detida a respeito da caracterização do contrato de franquia como agenciamento e do motivo pelo qual essa caracterização afastaria a incidência das regras imunizantes às agências franqueadas quando, ao atuarem na primeira fase do ciclo postal (o recebimento), captam, por exemplo, cartas, submetendo-as posteriormente à ECT, que viabilizará sua chegada ao usuário final.

\footnotetext{
${ }^{214} \mathrm{AC}$ n. ${ }^{\circ}$ 2.324-MC-AgR/RS, p. 143.

${ }^{215} \mathrm{AC}$ n. ${ }^{\circ}$ 2.324-MC-AgR/RS, p. 142-144.
} 
Será que ao atuarem no núcleo de serviços postais propriamente ditos (serviços públicos), representando a marca ECT, as agências franqueadas também não deveriam se valer do privilégio da imunidade tributária? Tendo em vista que, conforme entrevista na ABRAPOST-SP, as agências franqueadas submetem-se a toda a carga tributária de quaisquer empresas comuns, em que medida é legítima a concorrência entre uma agência própria e uma agência franqueada? Essas também são questões que ainda não foram alvo de uma preocupação mais detida do STF, mas que certamente ainda são importantes para aprimorar o debate mais amplo sobre o setor postal brasileiro.

\section{V.2.3.3. Validação de um setor paralelo de prestadores}

Além disso, as afirmações jurisprudenciais, que tendem a ser generalizantes e pouco comprometidas com a realidade do setor postal, acabam por recair na mesma contradição anteriormente assinalada em termos doutrinários.

Se todas as atividades integrantes da rede postal têm a natureza jurídica de serviço público, partindo-se da tradicional dicotomia serviços públicos versus atividades econômicas, para que as empresas privadas pudessem explorar serviços postais deveriam ter participado de um certame licitatório, ao final do qual celebrassem com o poder público um contrato de concessão ou permissão. Como isso não tem sido constatado na prática, no limite o Tribunal acaba por validar (legitimar) um verdadeiro setor paralelo de prestadores de serviços postais, que atuam numa área que não está reconhecida pela lei ou pela regulamentação.

\section{V.2.3.4. Impacto sobre as franquias postais}

Uma vez que o serviço postal seja considerado serviço público fazem sentido os questionamentos sobre a falta de procedimento licitatório que anteceda a celebração dos contratos de franquia, nos termos do que prevê o art. 175 da Constituição. O tema da delegação dos serviços postais através das franquias sem prévia licitação foi inicialmente questionado no âmbito do Tribunal de Contas da União, mas a polêmica acabou se estendendo de modo tal que até hoje a questão pende de apreciação no STF e, na seara legislativa, ganhou nova disciplina, com a conformação de um modelo diferente do que 
atualmente está sendo operado (Correios Conveniência), e já tem sido implantado, disciplinado pelas regras previstas na lei n. ${ }^{\circ} 11.668 / 08$ e no decreto n. ${ }^{\circ} 6.639 / 08$.

A partir do ano de 1994, momento em que o TCU determinou que a ECT passasse a observar o procedimento licitatório para a concessão de novas franquias, como já visto (item III.1.2.2), uma série de instrumentos normativos foram elaborados, a fim de postergar o término das contratações realizadas pela ECT sem licitação (lei n. ${ }^{\circ}$ 9.648/98, lei n. ${ }^{\circ}$ 10.577/02, medida provisória n. ${ }^{\circ}$ 403/07, lei n. ${ }^{\circ}$ 11.668/08), o que tem sido alvo de diversos questionamentos, inclusive no âmbito do STF.

A prorrogação ocasionada pela lei n. ${ }^{\circ} 11.668 / 08$ fez com que o Procurador-Geral da República, em 06 de outubro de 2008, ajuizasse perante o STF ação direta de inconstitucionalidade em face dos dispositivos que prorrogavam as franquias, com pedido liminar. Sua pretensão justificava-se no fato de ser a ECT uma empresa prestadora de serviço público, cuja delegação pressupõe a ocorrência de procedimento licitatório (CF, art. 175). Segundo ele, as sucessivas prorrogações tinham tido uma razão de ser: manter a continuidade da prestação do serviço. Entretanto, o advento da nova lei estaria por perpetuar um estado de temporariedade que havia se tornado permanente pelas sucessivas prorrogações, que vinham se arrastando desde 1998.

O Procurador ainda chamava atenção para as conclusões a que havia chegado a Comissão Parlamentar Mista de Inquérito - CPMI dos Correios: (i) teria havido uma grande migração de clientes para as agências franqueadas, sendo que a ECT tinha condições de prestar-lhes os serviços sem intermediação das franquias e consequente comissionamento; e (ii) não era possível a contabilização da integralidade do fluxo postal por parte de certos franqueados. Essa ADI ainda está tramitando no STF; trata-se da Ação Direta de Inconstitucionalidade n. ${ }^{\circ}$ 4.155-0/DF. No dia 04 de dezembro de 2008, o ministro Eros Grau, em despacho, decidiu que em face da relevância do caso a decisão do STF deveria ser tomada em caráter definitivo e não em cautelar. Ainda hoje não há decisão final da Corte $^{216}$.

Pouco tempo depois do ajuizamento desta ADI, em 07 de novembro de 2008 foi editado o decreto n. $^{\circ}$ 6.639, regulamentando a lei que trata do exercício da atividade de franquia postal, e cerca de seis meses depois, em 12 de junho de 2009, o ministro Gilmar Mendes proferiu decisão monocrática (Suspensão de Tutela Antecipada n. ${ }^{\circ}$ 335/DF), já

${ }^{216}$ Última atualização da pesquisa em 20.12.2011. 
mencionada e analisada no Capítulo 1 (item III.1.2.2), em que deferiu pedido de tutela antecipada formulado pela União, sustando os efeitos do acórdão proferido pelo Tribunal Regional Federal que havia determinado que a ECT promovesse, no prazo de cento e oitenta dias, a substituição de todos os contratos de franquia celebrados sem prévia licitação, em face do receio de que a ECT não tivesse capacidade de assumir a prestação dos serviços que atualmente são prestados pela rede franqueada.

Os novos contratos de franquia (Correios Conveniência) são disciplinados pela lei n. ${ }^{\circ}$ 11.668/08 e pelo decreto n. ${ }^{\circ}$ 6.639/08, como anteriormente mencionado. Além de as outorgas serem feitas mediante procedimento licitatório, têm prazo de vigência e objeto delimitado (dez anos, e restrição das atividades exploradas às auxiliares, restritas às atividades de "...produção ou preparação de objeto de correspondência, valores e encomendas que antecedem o recebimento desses postados pela ECT, para posterior distribuição e entrega aos destinatários finais") (art. $2^{\circ}, \S 1^{\circ}$ do decreto).

Por meio desta previsão e do art. $2^{\circ}$ da nova lei de franquias, a ECT é responsável pela “...recepção dos postados das franqueadas, sua distribuição e entrega aos destinatários finais", sendo expressamente vedado que as atividades de recebimento, expedição, transporte e entrega de objetos de correspondência, valores e encomendas, inerentes à prestação dos serviços postais, sejam objeto de contrato de franquia (art. $2^{\circ}, \S 2^{\circ}$ do decreto).

Inicialmente, a MP previa um objeto mais amplo aos contratos de franquia. As atividades auxiliares consistiriam na “...prestação da atividade de atendimento e venda de produtos disponibilizados pela ECT junto a clientes do segmento de varejo e comercial", produtos esses que seriam posteriormente delimitados pela ECT $\left(\operatorname{art.} 1^{\circ}, \S \S 2^{\circ}\right.$ e $3^{\circ}$ ). A MP possibilitava ainda que as empresas franqueadas, mediante autorização da ECT, desenvolvessem atividades preliminares ou acessórias à postagem (art. $1^{\circ}, \S 4^{\circ}$ ). Tais dispositivos foram vetados por despacho do Presidente da República (mensagem n. ${ }^{\circ}$ 245, de 02 de maio de 2008), que entendeu que eles tinham caráter contrário ao interesse público. Segundo ele, o intuito da nova lei com a regulamentação das franquias postais era suprir a carência de recursos para investimento no setor e não reduzir a receita da ECT, o que ocorreria se houvesse a ampliação do escopo dos contratos de franquia, sendo que isso inclusive vulneraria o monopólio postal detido pela empresa. 
Analisados os problemas práticos oriundos da uniformização da natureza jurídica do serviço postal, necessário analisar outro ponto central e complexo do regime jurídico do setor postal, o "monopólio" postal.

\section{V.3. Interdição dos particulares à prestação de parte dos serviços postais e a validação pelo STF de um regime jurídico protetivo à ECT}

\section{V.3.1. Discussão sobre a existência do "monopólio" postal constitucional}

De acordo com grande parte dos doutrinadores e com a linha de entendimento que prevaleceu no julgamento da $\operatorname{ADPF}$ n. 46-7/DF, a noção de "monopólio" remete às atividades econômicas em sentido estrito, sendo inaplicável ao conceito de serviço público. Por esta linha de entendimento, as previsões da Constituição Federal, especificamente do seu art. 21, XXIII ${ }^{217}$, que prevê monopólio federal de minerais nucleares, e do art. $177^{218}$, que também estabelece monopólios federais em relação a atividades relacionadas a petróleo, gás natural e outros hidrocarbonetos fluidos, minérios e minerais nucleares e seus derivados, são inaplicáveis aos serviços postais. A partir desse entendimento, o conceito de serviço público já enseja a reserva de sua prestação pelo poder público, sendo, pois, equivocada a utilização do termo "monopólio" no caso de atividades tidas como serviço público.

Neste sentido, Eros Grau, enquanto doutrinador, entende que os monopólios previstos no texto constitucional (artigos 177 e 21, XXIII) são de atividades econômicas em sentido estrito. A exclusividade na prestação de serviços públicos, para o autor, não

\footnotetext{
217 “Art. 21. XXIII - explorar os serviços e instalações nucleares de qualquer natureza e exercer monopólio estatal sobre a pesquisa, a lavra, o enriquecimento e reprocessamento, a industrialização e o comércio de minérios nucleares e seus derivados, atendidos os seguintes princípios e condições: (...)".

218 “Art. 177. Constituem monopólio da União: I - a pesquisa e a lavra das jazidas de petróleo e gás natural e outros hidrocarbonetos fluidos; II - a refinação do petróleo nacional ou estrangeiro; III - a importação e exportação dos produtos e derivados básicos resultantes das atividades previstas nos incisos anteriores; IV o transporte marítimo do petróleo bruto de origem nacional ou de derivados básicos de petróleo produzidos no País, bem assim o transporte, por meio de conduto, de petróleo bruto, seus derivados e gás natural de qualquer origem; V - a pesquisa, a lavra, o enriquecimento, o reprocessamento, a industrialização e o comércio de minérios e minerais nucleares e seus derivados, com exceção dos radioisótopos cuja produção, comercialização e utilização poderão ser autorizadas sob regime de permissão, conforme as alíneas b e $c$ do inciso XXIII do caput do art. 21 desta Constituição Federal. (Redação dada pela Emenda Constitucional n. ${ }^{\circ}$ 49, de 2006)".
} 
constitui monopólio, mas sim privilégio ${ }^{219}$. De maneira semelhante, o ministro Eros Grau se manifesta quando do exercício de sua atuação judicante (posição majoritária). Entende o ministro que é necessário apartar-se o regime de privilégio, de que se reveste a prestação dos serviços públicos, do regime de monopólio sob o qual, algumas vezes, a exploração de atividade econômica em sentido estrito é empreendida pelo Estado: "Monopólio é de atividade econômica em sentido estrito. Já a exclusividade da prestação dos serviços públicos é expressão de uma situação de privilégio"220. Neste sentido, afirma que os regimes jurídicos sob os quais são prestados os serviços públicos importam em que sua prestação seja desenvolvida sob privilégios, inclusive em regra o da exclusividade na prestação, o que acaba tornando atrativo para o setor privado a sua exploração em situação de concessão ou permissão.

Partindo desse posicionamento doutrinário e jurisprudencial, a questão da recepção ou não do "monopólio" postal incorre em equívoco, eis que a denominação "monopólio" caracteriza-se mais como um uso impróprio da expressão (expressão que inclusive é usada na lei n. ${ }^{\circ}$ 6.538/78), não sendo a exclusividade na prestação do serviço comparável aos artigos 177 e 21, XXIII da Constituição. A exclusividade de que se reveste a prestação dos serviços públicos não constitui "monopólio", mas sim privilégio.

De outro lado, na doutrina e nas decisões do STF, há quem questione a recepção do "monopólio" postal (posição minoritária). Partindo do pressuposto segundo o qual o serviço postal é atividade econômica, Luís Roberto Barroso argumenta que fosse serviço público, a lei ordinária não teria motivo para instituir monopólio no setor postal, como de fato o fez. Bastaria que sua prestação não fosse concedida ou permitida para seu desempenho ser exclusivamente estatal ${ }^{221}$. E fosse considerado serviço público pela ECT, ela não teria franqueado sua atividade, por simples contrato e não nos moldes do que prevê o art. 175 da Constituição ${ }^{222}$.

\footnotetext{
${ }^{219}$ Eros Grau, A ordem econômica na Constituição de 1988, p. 140. Em relação à impropriedade do uso do termo "monopólio" para os serviços públicos, ver também Floriano de Azevedo Marques Neto, "A nova regulação dos serviços públicos", Revista de Direito Administrativo, v. 228, p. 20.

${ }^{220}$ ADPF n. ${ }^{\circ} 46-7 / \mathrm{DF}$, p. 89.

${ }^{221}$ Luís Roberto Barroso, "Regime constitucional do serviço postal: legitimidade da atuação da iniciativa privada", Revista de Direito Administrativo, n. ${ }^{\circ} 22$, p. 203: "Os serviços públicos já são, por assim dizer, essencialmente 'monopolistas': aos particulares só se pode ser delegado seu exercício, e ainda assim mediante um ato negocial específico do Poder Público, precedido de um procedimento administrativo de licitação (art. 175, CF). Conseqüentemente, basta que não se conceda ou permita a prestação de determinado serviço para que ele seja desempenhado exclusivamente pelo Estado".

${ }^{222}$ Luís Roberto Barroso, "Regime constitucional do serviço postal: legitimidade da atuação da iniciativa privada", Revista de Direito Administrativo, n. ${ }^{\circ} 22$, p. 205-206.
} 
Como atividade econômica que é, o serviço postal poderia a princípio, quanto à forma de atuação estatal, ser prestado sob forma monopolizada ou sob forma não monopolizada e regime concorrencial. Como apenas subsistiriam os monopólios previstos no art. 177 da Constituição e não seria possível ampliar-se o rol de monopólios por lei (do que não seria possível considerar-se que a lei que previa o monopólio dos serviços postais - lei n. ${ }^{\circ} 6.538 / 78$ - teria sido recepcionada pela nova ordem constitucional) ${ }^{223}$, “...a prestação de serviços postais pelo Estado deve ser entendida como forma de exploração estatal de atividade econômica não monopolizada" e sob regime concorrencial ${ }^{224}$, sendo, pois, livres aos particulares os “...os serviços de entrega, recebimento, expedição e transporte de objetos de correspondências, valores ou encomendas, independentemente de ato de delegação prévia do Poder Público,225.

Nesta linha, no julgamento da ADPF n. ${ }^{\circ}$ 46-7/DF o ministro Marco Aurélio argumenta que quando o legislador constituinte quis remeter à necessidade de exploração direta da atividade pelo Estado, o fez expressamente (art. 21, incisos XI, XII alíneas a, b, c, d, e, f), e a Constituição é exaustiva também no tocante à instituição do monopólio da atividade econômica (artigos 21, XXIII e 177), pelo que "Somente o intérprete mais criativo poderia concluir que o verbo 'manter', a compelir a União a assumir os ônus relativos aos serviços postais, significa na verdade 'prestação direta ou mediante delegação a empresa pública, em regime de reserva de mercado'. A prevalecer esse entendimento, é dado imaginar uma interpretação extensiva, no sentido de dizer que, onde na Constituição se lê 'manter', leia-se 'monopólio', o que é absolutamente risível’226.

\footnotetext{
${ }^{223}$ Cf. Luís Roberto Barroso, "Regime constitucional do serviço postal: legitimidade da atuação da iniciativa privada", Revista de Direito Administrativo, n. '22, p. 208 e 210.

224 "Regime constitucional do serviço postal: legitimidade da atuação da iniciativa privada", Revista de Direito Administrativo, n. ${ }^{\circ} 22$, p. 208.

225 "Regime constitucional do serviço postal: legitimidade da atuação da iniciativa privada", Revista de Direito Administrativo, n. ${ }^{\circ} 22$, p. 208.

${ }^{226} \mathrm{ADPF}$ n. ${ }^{\circ} 46-7 / \mathrm{DF}$, p. $67-68$.
} 
Para ele, "manter" significa um conjunto de serviços que devem ser garantidos necessariamente pela União, o que abrangeria inclusive eventual exigência de prestá-los diretamente, quando não houver interesse econômico suficiente à implementação da atividade em determinados pontos do território nacional. Neste sentido, a atuação do Estado na atividade econômica deve ocorrer apenas quando esta se mostrar falha ou insuficiente, de modo que o poder público aja de maneira a corrigir as imperfeições que o mercado sozinho não for capaz de corrigir. A esse respeito, entende que não há qualquer menção na Constituição Federal de 1988 ao monopólio na prestação de serviços postais, e quando a lei foi editada em 1978 atendia-se a previsão da Constituição de 1967, repetida na Emenda Constitucional n. ${ }^{\circ}$ 1, de 1969 , no sentido de que a legislação infraconstitucional poderia fixar monopólios, isto porque naquela época a atuação estatal na economia não se fazia de forma subsidiária.

Ainda, entende o ministro que não se pode admitir que a liberdade de iniciativa conviva com o "monopólio", e que o sistema de franquias do Brasil serve como reforço de argumentação no sentido de que não se pode considerar o serviço postal como um serviço público exclusivo e monopolístico; mesmo o art. 175 da Constituição proibindo a delegação de serviço público sem que seja precedido de licitação, a ECT realizou entre 1990 e 1994 quase dois mil contratos de franquia, talvez por perceber que não se tratava mais de serviço público.

Partindo desse posicionamento doutrinário e jurisprudencial, a questão da recepção ou não do "monopólio" postal se coloca especialmente importante porque, diferentemente do que faziam a Constituição de 1967 e a Emenda Constitucional n. ${ }^{\circ}$ 1, de $1969^{227}$ (sob a égide das quais a legislação postal foi editada), a Carta de 1988 não prevê a possibilidade de instituição de monopólio por lei infraconstitucional, pelo que seria bastante discutível a possibilidade de o rol de monopólios constitucionais ser ampliado mediante lei, dado o caráter excepcional que qualquer regime monopolista tem no ordenamento jurídico vigente, que em grande medida preza por ambientes concorrenciais. Além de discutível no plano teórico, a questão estaria ganhando nos últimos anos grande proporção prática, por conta da proliferação desenfreada de prestadores dos serviços postais que se verificou nas últimas décadas (são cerca de 15.000 empresas privadas que atuam no setor e que buscam

${ }^{227}$ Cf. art. $157, \S 8^{\circ}$ da $\mathrm{CF} / 67$ e art. 163 da EC n. ${ }^{\circ} 1 / 69$. Ambos os textos legais preveem a possibilidade de criação de monopólio de determinada indústria ou atividade por lei federal “...quando indispensável por motivo de segurança nacional ou para organizar setor que não possa ser desenvolvido com eficácia no regime de competição e de liberdade de iniciativa, assegurados os direitos e garantias individuais". 
ampliar sua participação nele e há ainda a prestação dos serviços pelas agências franqueadas), o que tem gerado uma judicialização reiterada no setor.

Diante dessa diversidade de entendimentos acerca da questão da recepção do "monopólio" postal e partindo-se do pressuposto segundo o qual a diferenciação entre "monopólio" e "privilégio" é útil para que não se comparem coisas distintas ${ }^{228}$, embora a consequência de um "monopólio" ou de um "privilégio" seja a mesma, qual seja, a exclusividade na prestação de determinado serviço, a importância que tem sido dada a essa conceituação diferenciada justifica o uso ao longo deste trabalho das aspas quando o termo for referido e a utilização dos termos "privilégio", "exclusividade" ou "interdição".

Feitas essas considerações iniciais, é importante destacar que a interdição dos particulares à prestação de parte dos serviços postais não advém expressamente do texto constitucional, que nada prevê a este respeito, não se referindo à existência ou inexistência de qualquer exclusividade da ECT. Por outro lado, como será analisado no item V.3.3.2, considera-se que a prestação de serviços públicos não é necessariamente exclusiva.

O decreto-lei n. ${ }^{\circ}$ 509/69, no entanto, expressamente confere à ECT a execução e controle dos serviços postais em regime de monopólio (art. 2º I) - a MP n. ${ }^{\circ}$ 509, recentemente aprovada, não alterou essa previsão -, cujo alcance foi posteriormente delimitado pela lei n. $^{\circ} 6.538 / 78$.

É a legislação infraconstitucional, portanto, que confere exclusividade à prestação do serviço postal, delimitando-a, inclusive porque é a lei que, como visto, diz que os serviços postais são serviços públicos. Trata-se de conclusão importante, uma vez que, admitindo-se que a Constituição não restringiu as opções do legislador, a legislação infraconstitucional tem ampla margem para a normatização do setor, inclusive para tornar competitivas as áreas atualmente exclusivas, disciplinando como se dará a coexistência entre a prestação pública (pela ECT) e as empresas privadas, num regime competitivo ou semicompetitivo.

\footnotetext{
${ }^{228}$ A este respeito, ver Fernando Dias Menezes de Almeida, "Aspectos constitucionais da concessão de serviços públicos”. In: MEDAUAR, Odete (coord.). Concessão de serviço público, p. 32. Em suas palavras, “...uma vez aceita a distinção acima exposta [entre serviços públicos e atividades econômicas], não há que se falar em 'monopólio de serviços públicos', nem em 'concessão de atividades econômicas'. O monopólio é figura que se aplica apena a estas últimas, enquanto concessão refere-se exclusivamente a serviços públicos".
} 


\section{V.3.2. Distanciamento da lei n. $^{0} \quad 6.538 / 78$ em relação à realidade setorial e judicialização do privilégio do "monopólio" postal}

Há na legislação uma delimitação do alcance do "monopólio" postal que, no entanto, é em grande medida insuficiente. Segundo os artigos $9^{\circ}, 26$, parágrafo único e 27 da lei n. ${ }^{\circ}$ 6.538/78, são exploradas em regime de "monopólio" as seguintes atividades: (i) recebimento, transporte e entrega, no território nacional, e expedição, para o exterior, de carta, cartão-postal; (ii) fabricação, emissão de selos e de outras formas de franqueamento postal; (iii) o serviço de telegrama; e (iv) a inserção de propaganda e a comercialização de publicidade nos formulários de uso no serviço de telegrama.

Por expressa previsão legal $\left(\right.$ art. $9^{\circ}, \S 2^{\circ}$ ), estariam fora do "monopólio" legal o transporte de carta e cartão-postal (i) efetuado entre dependências da mesma pessoa jurídica, em negócios de sua economia, por meios próprios, sem intermediação comercial; e (ii) os executados eventualmente e sem fins lucrativos. Existiriam ainda alguns serviços que poderiam ser prestados mediante prévia e expressa autorização da ECT (art. $9^{\circ}, \S 1^{\circ}$ ), (i) a venda de selos e outras fórmulas de franqueamento postal; e (ii) a fabricação, importação e utilização de máquinas de franquear correspondência, bem como de matrizes para estampagem de selo ou carimbo postal.

Diante dessas previsões normativas, o alcance do "monopólio" legal da ECT relaciona-se em grande medida às definições de carta, cartão-postal, selos, franqueamento postal e telegrama, apresentadas no art. 47 da lei: (i) "Carta - objeto de correspondência, com ou sem envoltório, sob a forma de comunicação escrita, de natureza administrativa, social, comercial, ou qualquer outra, que contenha informação de interesse específico do destinatário"; (ii) "Cartão-Postal - objeto de correspondência, de material consistente, sem envoltório, contendo mensagem e endereço"; (iii) "Selo - estampilha postal, adesiva ou fixa, bem com a estampa produzida por meio de máquina de franquear correspondência, destinadas a comprovar o pagamento da prestação de um serviço postal"; (iv) "Franqueamento Postal - pagamento de tarifa e, quando for o caso, do prêmio, relativos a objeto postal, diz-se também da representação da tarifa"; e (v) “Telegrama - mensagem transmitida por sinalização elétrica ou radioelétrica, ou qualquer outra forma equivalente, a ser convertida em comunicação escrita, para entrega ao destinatário".

O alcance do "monopólio" também se relaciona ao objeto de atividades exploradas pela empresa. Como ele engloba mais atividades do que as expressamente 
"monopolizadas" pela lei, numa leitura sistemática do seu texto estariam fora do "monopólio" legal algumas atividades, que incluem serviços como os impressos, cecogramas e as pequenas-encomendas; e alguns serviços, relativos a valores (recebimento de tributos, prestações, contribuições e obrigações pagáveis à vista, por via postal) e a encomendas (remessa e entrega de objetos, com ou sem valor mercantil, por via postal).

Os impressos são definidos pela lei como "reprodução obtida sobre material de uso corrente na imprensa, editado em vários exemplares idênticos". O cecograma é "objeto de correspondência, com ou sem envoltório, sob a forma de comunicação escrita, de natureza administrativa, social, comercial ou qualquer outra, que contenha informação de interesse específico do destinatário". A pequena-encomenda, por sua vez, é definida como "objeto de correspondência, com ou sem valor mercantil, com peso limitado, remetido sem fins comerciais".

Para dar efetividade às suas previsões normativas, a lei tipificou diversas condutas como criminosas e especificou as penas correspondentes. Dentre elas está o crime de violação do privilégio postal da União. Nos termos da lei, aquele que "Coletar, transportar, transmitir ou distribuir, sem observância das condições legais, objetos de qualquer natureza sujeitos ao monopólio da União, ainda que pagas as tarifas postais ou de telegramas" se sujeita à pena de detenção, de até dois meses ou pagamento não excedente a dez dias-multa (art. 42). A lei ainda prevê para o crime uma forma assemelhada, ao estabelecer que "Incorre nas mesmas penas quem promova ou facilite o contrabando postal ou pratique qualquer ato que importe em violação do monopólio exercido pela União sobre os serviços postais e de telegramas" (art. 42, parágrafo único).

Essa enunciação do tratamento que a legislação dá ao setor subsidiará a análise posterior sobre qual é o real alcance do "monopólio" postal, e será fundamental para que se chegue à constatação de que a lei n. ${ }^{\circ}$ 6.538/78 distancia-se da realidade setorial, o que em grande medida tem feito com que o Poder Judiciário tenha de se manifestar sobre o "monopólio", especialmente sobre sua recepção e alcance.

\section{V.3.3. Análise crítica da ADPF n. 46-7: as armadilhas da recepção do "monopólio" postal}

Com vistas a garantir a exclusividade que lhe foi conferida pela lei, e valendo-se da

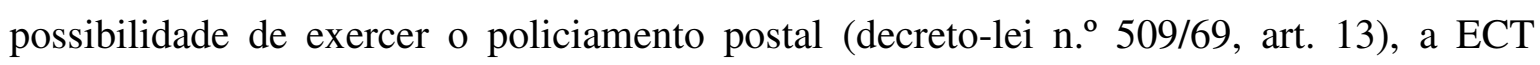


passou a fazer frente à expansão das empresas privadas que atuam no setor. A estatal passou a enviar notificações aos clientes de empresas privadas dizendo que elas desempenhavam atividades ilegais e passíveis de punições civis e criminais, e passou a tomar medidas criminais de busca e apreensão, condução de funcionários à delegacia, mediante escolta policial, dentre outras medidas ${ }^{229}$.

Diante desse cenário, no final do ano de 2003, a Associação Brasileira das Empresas de Distribuição (ABRAED) ajuizou junto ao STF arguição de descumprimento de preceito fundamental (ADPF n.o 46-7/DF). Alegava a associação que inexiste um "monopólio" constitucional, uma vez que o verbo "manter" não daria ensejo a tal interpretação, e que a lei n. ${ }^{\circ}$ 6.538/78 fora tacitamente revogada pela Constituição de 1988, que (i) não prevê a possibilidade de instituição de "monopólio" por lei infraconstitucional; e (ii) estabelece no rol do art. 177 os "monopólios" existentes no Brasil, os quais são taxativos em virtude dos princípios constitucionais da livre-iniciativa (CF, art. $\left.1^{\circ}, \mathrm{IV}\right)$, liberdade de exercício de qualquer trabalho (CF, art. $5^{\circ}$, XIII) e livre concorrência (CF, art. 170, caput; IV). Em consonância com esta linha de raciocínio, o serviço postal seria uma atividade econômica (e não um serviço público).

As empresas de distribuição estariam sendo vítimas da ECT porque inexistente o "monopólio". E ainda que este pudesse ser admitido, não teriam adentrado o terreno exclusivo da ECT, pois em momento algum pretendiam “...entregar ou distribuir cartas, entendidas estas como correspondências de cunho pessoal, íntimo e sigiloso..." ${ }^{230}$. Sob este aspecto, o conceito de carta não compreenderia, por exemplo, as correspondências de mala direta, revistas, jornais e periódicos, encomendas, contas de luz, água, telefone, gás etc. e outros objetos bancários, como talões de cheques, cartões de crédito etc.

Neste sentido, pediam que os ministros julgassem a ação totalmente procedente a fim de que reconhecessem a violação aos preceitos fundamentais da livre-iniciativa, da livre concorrência e do livre exercício de qualquer trabalho, declarassem a inconstitucionalidade da lei n. ${ }^{\circ}$ 6.538/78, especialmente sobre a questão do "monopólio" de entrega de correspondências, e o que se entende por carta.

\footnotetext{
${ }^{229}$ Cf. petição inicial da ADPF n. ${ }^{\circ} 46-7 / D F$, p. 15.

${ }^{230}$ Cf. petição inicial da ADPF n. ${ }^{\circ}$ 46-7/DF, p. 9. Adiante, assevera a ABRAED que carta é o “...papel escrito, metido em envoltório fechado, que se envia de uma parte a outra para comunicação entre pessoas distantes; manuscrito fechado com endereço (cf. Dicionário Brasil Contemporâneo)".
} 
Em manifestação ${ }^{231}$, a ECT alegou ser uma empresa pública prestadora de serviço público, já que o serviço postal seria atividade de interesse coletivo na qual o Estado está presente e que se desenvolve por um procedimento de direito público. Consoante previsão da lei n. ${ }^{\circ}$ 6.538/78, o rol do art. $9^{\circ}$ corresponde a serviços públicos exclusivos. O art. 177 da Constituição não teria previsto o "monopólio" postal porque o serviço postal não corresponderia a atividade de natureza privada.

Ante a previsão do art. $9^{\circ}$ e as definições do art. 47 da lei n. ${ }^{\circ}$ 6.538/78, estaria compreendida no "monopólio" postal, no gênero "cartas endereçadas a diversas pessoas naturais e jurídicas ${ } 232$ a entrega de contas relativas ao consumo de energia elétrica e de água, de documentos bancários etc. As empresas de distribuição não poderiam legitimamente atuar nesta seara da "carta" (bem como no campo do selo), podendo realizar serviços de distribuição de encomendas e impressos (jornais, revistas, livros, mala direta etc.).

O cerne da ação refere-se a duas questões centrais: (i) o "monopólio" legal foi recepcionado pela Constituição de 1988?; e (ii) se foi recepcionado, qual é o seu alcance? Quase seis anos se passaram até que o STF decidisse o caso (em 05/08/2009), pela improcedência da ação e consequente recepção da lei que delimitou o "monopólio" postal (lei n. ${ }^{\circ}$ 6.538/78). O problema é que não é tão simples dizer em termos práticos o que isso significa.

A partir de uma análise crítica da ADPF n. ${ }^{\circ}$ 46-7/DF, verifica-se que a recepção do "monopólio" postal, tal como ocorreu no julgamento, cria os seguintes problemas práticos para o setor postal brasileiro (a ideia de armadilhas): o campo de serviços "monopolizados" foi delimitado de maneira incerta, foi feita uma correlação entre serviço público e prestação "monopolista", bem como entre "monopólio" e universalização, a decisão final da ADPF revela-se contraditória em relação à natureza jurídica de serviço público da rede postal e traz o desafio de se lidar com a proliferação de prestadores privados e a necessidade de avaliar-se a função do "monopólio" postal. Essas ideias serão desenvolvidas na sequência.

\footnotetext{
${ }^{231}$ A íntegra da manifestação da ECT não está disponível no site do Supremo Tribunal Federal. Para uma resenha dos principais argumentos nela desenvolvidos, ver relatório do ministro Marco Aurélio, p. 10-14. ${ }^{232}$ Cf. relatório do ministro Marco Aurélio, p. 13.
} 


\section{V.3.3.1. Delimitação incerta do campo de serviços não "monopolizados"}

A despeito das previsões legais terem sido recepcionadas, há uma clara dificuldade de as atividades atualmente prestadas como serviços postais se subsumirem na prática às prescrições da antiga lei.$^{\circ}$ 6.538/78, editada numa época em que a complexidade das atividades postais era sensivelmente diversa.

O que significa hoje poder transportar impressos, cecogramas, pequenasencomendas, serviços relativos a valores e encomendas (atividades sobre as quais não se estende o regime de exclusividade)? O cheque é encomenda e por isso sua distribuição é livre ou é carta e, portanto, sua distribuição é "monopolizada"? E se uma sociedade de economia mista como a Companhia de Saneamento Básico do Estado de São Paulo (Sabesp) implantar um sistema de leitura de hidrômetro em que um técnico mede o consumo de água no local e ao mesmo tempo emite o boleto de cobrança ao cliente, estará ela ferindo o "monopólio" postal? ${ }^{233}$ Seria diferente o fato de ela estar prestando "serviços postais" para si e não para venda no mercado? É legítimo criarem-se obstáculos ao processo tecnológico em garantia do "monopólio" postal?

Essa dificuldade prática de se subsumir as atividades atualmente prestadas como serviços postais à lei n. ${ }^{\circ}$ 6.538/78 foi manifestada inclusive pela ABRAED no momento em que propôs a ação, quando a associação pediu que os ministros excluíssem do "monopólio" (do que chamaram de conceito de carta) as correspondências de mala direta, revistas, jornais e periódicos, encomendas, contas de luz, água, telefone e assemelhados, bem como objetos bancários como talões de cheque e cartões de crédito $^{234}$.

Os ministros do STF, quando do julgamento da ADPF n..$^{\circ}$ 46-7/DF foram chamados a se pronunciar a respeito dessa questão da delimitação do "monopólio", mas a tumultuada decisão final da Corte pouco esclareceu a respeito do alcance do "monopólio" que recepcionou, o que tem feito com que o debate ainda se arraste no tempo.

\footnotetext{
${ }^{233}$ O sistema de leitura do hidrômetro foi implantado pela Sabesp por volta de 2006. A ECT questionou esse mecanismo de distribuição de conta alegando ser detentora do "monopólio" postal. Em outubro de 2008 a ECT obteve uma liminar em primeira instância que impediu que a Sabesp realizasse o procedimento em parte da zona norte da cidade de São Paulo. Cerca de dois meses depois, em novembro, o caso foi julgado pelo Tribunal Regional Federal da $3^{\text {a }}$ Região que autorizou a entrega de contas de água diretamente aos consumidores. Cf. "Disputa entre Sabesp e ECT pelo direito de emitir boletos".

${ }^{234}$ Cf. petição inicial da ADPF n. ${ }^{\circ}$ 46-7/DF, p. 36 e relatório do acórdão.
} 
Em termos gerais, firmaram-se três posicionamentos: (i) uma primeira posição, minoritária, de acordo com a qual o serviço postal deve ser privado, pelo que a lei n. ${ }^{\circ}$ 6.538/78 não foi recepcionada (sustentada pelo ministro relator Marco Aurélio); (ii) uma posição, que prevaleceu no julgamento, conduzida pelo ministro Eros Grau, segundo a qual o serviço postal deve ser estatal, pelo que a lei n. ${ }^{\circ} 6.538 / 78$ foi recepcionada (ministros Eros Grau, Joaquim Barbosa, Cezar Peluso, Ellen Gracie, Cármen Lúcia e Carlos Britto, cujo entendimento, questionado ao longo da decisão em razão do "empate" inicial ${ }^{235}$, se aproximou mais do voto do ministro Eros Grau); e (iii) uma terceira posição, minoritária, intermediária, pela procedência parcial da ADPF, em diferente extensão, de acordo com a qual alguns serviços devem permanecer sob a exclusividade da atividade estatal e outros podem ser delegados à iniciativa privada (representada pelos ministros Gilmar Mendes, Ricardo Lewandowski, Celso de Mello - voto cujo inteiro teor não foi acostado aos autos, e pelo posicionamento inicial de Carlos Britto, posteriormente alterado).

Tendo prevalecido a posição conduzida pelo ministro Eros Grau, o Tribunal, por maioria de votos, julgou improcedente a ADPF. De maneira geral, essa corrente majoritária não se posiciona de maneira clara sobre a delimitação do "monopólio". Entendem que o serviço postal é serviço público (por definição constitucional) e que existe um regime de privilégio à ECT, cujos contornos seguem a lei n. ${ }^{\circ} 6.538 / 78$, recepcionada.

O ministro Eros Grau, condutor dessa corrente, não trata da delimitação dos serviços de prestação exclusiva pela ECT, limitando-se a afirmar que "Quanto ao âmbito do serviço postal, está bem desenhado nos artigos $7^{\circ}$ e seguintes da lei $n .^{\circ}$ 6.538/78, também recebida pela Constituição de 1988",236, afirmação que em certa medida desconsidera a realidade de prestação do serviço e as discussões a ela relacionadas.

O ministro Joaquim Barbosa, embora tenha votado no mesmo sentido de Eros Grau, se refere explicitamente às atividades que a ABRAED pedia que fossem excluídas do "monopólio", para afastar seu pleito. A partir do entendimento segundo o qual o art. $9^{\circ}$ da lei n. ${ }^{\circ}$ 6.538/78 estabelece as atividades a serem prestadas pela União em regime de privilégio e em seu art. 47 define claramente o que seja carta, o ministro entende que "Não há como excluir desse conceito legal de carta os boletos bancários e notificações para cobrança de débitos, faturas de consumo de gás, luz e outras, bem como qualquer

\footnotetext{
235 Por tratar-se de julgamento de ADPF, era necessária maioria de 6 votos, que foi obtida com o pronunciamento final do ministros Carlos Britto, pela improcedência da ação.

${ }^{236}$ ADPF n. ${ }^{\circ} 46-7 / \mathrm{DF}$, p. 91.
} 
correspondência que contenha informação de interesse específico do destinatário, como o são quaisquer cobranças de débitos",237. Essa tarefa de quebrar o regime de privilégio em relação à entrega de correspondência comercial só poderia ficar a cargo do legislador ordinário, ao qual compete estabelecer as hipóteses de prestação desse serviço pela iniciativa privada, através de contratos de concessão e permissão. Segundo o ministro, "Não cabe a esta Corte substituir o papel do legislador e fixar os critérios e formas para a prestação desse serviço público" ${ }^{238}$.

Sem se referir especificamente aos serviços que são ou não "monopolizados", diferentemente do ministro Joaquim Barbosa, a ministra Cármen Lúcia segue nessa linha de que a Constituição não é imutável e que a própria lei, “...naquilo que ela estipulou como podendo ser, ou não cabendo no caso do artigo $9^{\circ}(\ldots), 239$ pode ser alterada por outra, mas não haveria que se considerar a lei n. ${ }^{o}$ 6.538/78 não recepcionada ou dar-lhe interpretação conforme.

Por essa linha de entendimento, prevalecente no julgamento da ação, a lei já esclarece o escopo do "monopólio" de maneira clara, sendo desnecessário o pronunciamento do Tribunal a este respeito, entendimento que em certa medida se contrapõe à realidade do setor, marcada por discussões. Nesse sentido, a instituição STF não falou expressamente que correspondência comercial, por exemplo, não se enquadra nos serviços de impressos, cecogramas e encomendas (serviços não "monopolizados").

Isso é, não há especificação do conteúdo do "monopólio", de quais são os serviços ofertados hoje em dia que se enquadram nos conceitos apresentados pela lei e por ela definidos num passado em que a realidade de prestação dos serviços era sensivelmente diversa. Apenas no voto isolado do ministro Joaquim Barbosa vê-se uma preocupação em especificar o conteúdo dos serviços, e mesmo assim ele se refere apenas a documentos mercantis em geral e remete essa tarefa ao legislador, tal como também faz a ministra Cármen Lúcia.

A corrente de ministros do STF que procurou fazer uma especificação mais clara do conteúdo dos serviços postais foi a terceira, intermediária ${ }^{240}$, que, ao partir de uma diferenciação do conteúdo dos serviços (daí porque sua especificação), objetivou submetê-

\footnotetext{
${ }^{237}$ ADPF n. ${ }^{4}$ 46-7/DF, p. 109.

${ }^{238}$ ADPF n. ${ }^{\circ} 46-7 / \mathrm{DF}$, p. 110.

${ }^{239}$ ADPF n. $^{\circ}$ 46-7/DF, p. 138.

${ }^{240}$ Os ministros desta linha decisória julgaram a ADPF parcialmente procedente, em diferente extensão. Em anexo, encontram-se especificados os argumentos de cada uma das linhas de argumentação.
} 
los a regimes jurídicos distintos. A despeito disso, essa corrente revela uma dificuldade bastante grande de os ministros delimitarem o campo de serviços não "monopolizados".

O ministro Gilmar Mendes, em seu voto reajustado, decidiu-se por “...julgar parcialmente procedente a argüição, fixando a interpretação de que a prestação exclusiva pela União da atividade postal limita-se ao conceito de carta, cartão-postal e correspondência agrupada, nos termos do art. $9^{\circ}$ da Lei $n .^{\circ} 6.538 / 78$, não abarcando a distribuição de boletos (v.g. boletos bancários, contas de água, telefone, luz), jornais, livros, periódicos ou outros tipos de encomendas ou impressos" ${ }^{241}$. Vê-se claramente que houve uma preocupação do ministro em falar expressamente o que entendia estar fora do "monopólio" postal.

Posicionamento semelhante também foi adotado pelo ministro Ricardo Lewandowski, que considerou a ADPF parcialmente procedente, por entender que não estão abrangidos pelo "monopólio" estatal os serviços de correspondência comercial e a entrega de encomendas. Considerando a realidade de prestação dos serviços postais, entende o ministro que “...estão fora do monopólio estatal a entrega de talões de cheque, de cartão de crédito, de cartões de cobrança, brindes, documentos, amostras trocadas entre empresas, jornais, revistas, impressos que constituem uma atividade tipicamente econômica, até porque uma solução em sentido contrário militaria contra a realidade já delineada no mundo globalizado. Eu entendo, também, que estão excluídas desse monopólio as entregas de encomendas, os serviços de 'courier', mesmo porque já convivem com o correio estatal, não só no Brasil como no exterior, há muitos anos, com êxito, empregando centenas de milhares de pessoas $" 242$.

Inicialmente, o ministro Carlos Britto adotou essa posição intermediária, da qual inclusive foi precursor. Entendia o ministro que a exclusividade da União em prestar os serviços postais estaria circunscrita às atividades que impliquem comunicação privada e comunicação telegráfica. Estaria, pois, afastada da exclusividade da União o que tivesse caráter rigorosamente mercantil, comercial. Após o voto do ministro Gilmar Mendes, Carlos Britto chama a atenção para a necessidade de se definir o que seja serviço postal, eis que, segundo ele: "Com o voto de Vossa Excelência, robustece em mim a idéia de que realmente é preciso definir o que seja serviço postal. $O$ que não se compreender na definição de serviço postal está fora do conceito de serviço público. Por isso que Vossa

${ }^{241}$ ADPF n. ${ }^{\circ} 46-7 / \mathrm{DF}$, p. 224.

${ }^{242}$ ADPF n. ${ }^{\circ} 46-7 / \mathrm{DF}$, p. 140. 
Excelência falou de boleto, de jornal. (...) Avancei no meu voto, talvez para preservar três bens jurídicos: a integração nacional, o sigilo da correspondência e a privacidade. Adiantei no meu voto isso. E realmente esse é um tema que me causa uma inquietação intelectual. Não me encontro ainda confortável, a despeito do magnífico voto de Vossa Excelência" ${ }^{243}$.

Posteriormente, no entanto, chamando atenção para o fato de o tema ser de difícil cognição, dada sua complexidade, o ministro vota por excluir do âmbito de incidência da expressão serviço postal os impressos e as encomendas. Diante desse posicionamento, o ministro Gilmar Mendes questiona: "Portanto, boletos, contas, Vossa Excelência deixaria no conceito de cartas?", ao que Carlos Britto responde: "Deixaria", e Gilmar Mendes finaliza: "Na verdade, então, temos maioria no sentido da improcedência"244.

De fato, da leitura do texto da lei n. ${ }^{\circ} 6.538 / 78$ já se extrai que impressos e encomendas não são atividades prestadas sob regime de exclusividade, assim como atividades como cecogramas, pequenas-encomendas e alguns serviços relativos a valores (recebimento de tributos, prestações, contribuições e obrigações pagáveis à vista, por via postal). Mas isso, no entanto, precisou ser explicitado ao longo do julgamento pelos próprios advogados dos Correios, que tiveram de manifestar-se expressamente no sentido de que encomendas e impressos não são serviços exclusivamente prestados pela ECT.

Em face da manifestação dos advogados, o ministro Carlos Britto chega a afirmar: “...Assentei o regime juspublicístico do serviço e não o jusprivatístico, na linha do voto do Ministro Eros Grau. Eu nem sabia que na prática isso já estava excluído. Excluí, como efetivamente excluo, do âmbito material de incidência desta expressão 'serviço postal', os impressos, a partir do voto de Vossa Excelência, proferido anteontem, e contemplo aquela minha primeira preocupação: também afasto do âmbito de incidência as encomendas, ou seja, os volumes entregues para destinação a terceiros. Então, excluiria exclusivamente do meu voto ou do âmbito de incidência material dessa expressão constitucional serviço postal' tão-só os impressos e as encomendas" 245.

Diante disso, no dia seguinte ao julgamento (06/08/2009) foi publicada no jornal Folha de São Paulo ${ }^{246}$ uma matéria que dizia que as empresas privadas a partir da decisão poderiam explorar livremente o envio de encomendas, jornais e revistas, e os Correios

${ }^{243}$ ADPF n. ${ }^{\circ}$ 46-7/DF, p. 134 e p. 136.

${ }^{244}$ ADPF n. ${ }^{\circ} 46-7 / \mathrm{DF}$, p. $175-176$.

${ }^{245}$ ADPF n. ${ }^{\circ} 46-7 / \mathrm{DF}$, p. 175.

246 "Correios mantêm monopólio sobre serviços postais". 
manteriam a exclusividade do transporte de carta, cartão-postal e correspondência agrupada (malotes), por se tratar de serviço público.

O que a notícia não veiculou, no entanto, é que a corrente majoritária dos ministros (conduzida pelo voto do ministro Eros Grau), efetivamente não tratou desse ponto de maneira consistente, limitando-se a afirmar que o âmbito dos serviços postais está bem desenhado na legislação postal e, entendimento isolado de alguns ministros, que essa tarefa de especificar o conteúdo dos serviços postais deve ficar a cargo do legislador. O que essa decisão significou em termos práticos (as consequências da decisão do STF), no entanto, ficou num plano bastante secundário.

Nesse sentido, a notícia chamava atenção para a falta de consenso entre os ministros quanto à possibilidade de talão de cheque e cartão de crédito serem considerados encomenda ou carta. Este "problema" seria resolvido na análise de casos concretos que chegassem ao Judiciário. Por fim, segundo a matéria, o presidente do STF, ministro Gilmar Mendes, teria afirmado ao final do julgamento que os talões e cartões podem ser considerados encomendas, e defendeu a formulação de uma nova lei de serviços postais para a resolução dos impasses. Esse entendimento do ministro Gilmar Mendes, no entanto, claramente reflete sua posição intermediária, minoritária, de que as correspondências comerciais de maneira geral não são alcançadas pela exclusividade da União. Não reflete, no entanto, o posicionamento da instituição STF.

Em meio a esse cenário, em 05 de março de 2010 a ABRAED opôs embargos de declaração contra a decisão da ADPF n. ${ }^{\circ}$ 46-7/DF. Fundamentalmente a associação pedia que o STF explicitasse os elementos essenciais do conceito de encomenda, segmento no qual, pela decisão do Tribunal, as empresas privadas de entrega expressa podem atuar em regime concorrencial com a ECT. Nessa ação a associação manifestava uma clara preocupação com o risco de as empresas continuarem sendo perseguidas pela ECT, pela falta de delimitação das atividades postais sobre as quais se estende o regime de exclusividade da estatal ${ }^{247}$.

${ }^{247}$ Petição de oposição de embargos de declaração - ADPF n. ${ }^{\circ}$ 46-7/DF, p. 1510-1514. 
O julgamento dos embargos estava previsto para 24 de agosto de 2011, conforme a pauta de julgamentos para a sessão plenária do $\mathrm{STF}^{248}$. Nessa data, através de petição, a associação requereu a desistência dos embargos de declaração opostos, que foi homologada pelo ministro Luiz Fux em 29 de agosto de $2011^{249}$.

Na medida em que o julgamento da ADPF n. ${ }^{\circ}$ 46-7/DF não delimitou claramente o campo que seria livre à exploração das empresas privadas (quais serviços estariam fora do "monopólio" postal), os conflitos no setor tendem a se perpetuar ao longo do tempo. Podese argumentar, tal como fizeram alguns ministros em posicionamentos isolados, que definir precisamente os serviços que devem ser prestados exclusivamente pela União não é competência do STF, cujos ministros não têm nem mesmo capacidade técnica para especificar que a entrega de "x" é uma encomenda e a entrega de "y" é uma carta, e que caberia à legislação postal melhor delimitar o que deve ser entendido por encomenda, a partir de delimitações de peso e formato ou mesmo atributos de segurança, ou seja, de requisitos legais (e infralegais), ainda que mínimos, para se diferenciar as atividades postais.

A despeito disso, dada a repercussão que esse julgamento tem no cenário atual do setor postal e o entendimento do STF de que a legislação postal foi recepcionada, pode-se questionar se não caberia ao Tribunal dar uma interpretação mais funcional à legislação, concatenando-a e articulando-a em vista da realidade setorial, que muitas vezes parece ser relegada a um plano bastante secundário. A instituição STF, por exemplo, tal como fez o ministro Joaquim Barbosa (corrente majoritária), poderia ter expressamente afirmado que cabe à União, exclusivamente, entregar correspondências comerciais (boletos bancários e notificações para cobrança de débitos, faturas de consumo de gás, luz e outras), a partir do entendimento de que englobam o conceito de carta ("monopolizada") e não de encomendas ou impressos. Com isso, embora o STF tenha se manifestado sobre questões centrais do setor, seu posicionamento não foi capaz de trazer ao setor efetiva segurança jurídica.

\footnotetext{
${ }^{248}$ Cf. Notícias STF, "Pauta de julgamentos previstos para a sessão plenária desta quarta", de 23 de agosto de 2011. Disponível em: <http://www.stf.jus.br/portal/cms/verNoticiaDetalhe.asp?idConteudo=187129\&caixaBusca=N>. Acesso: 29.08.2011.

249 Disponível em: <http://www.stf.jus.br/portal/processo/verProcessoAndamento.asp?incidente=2182784>. Acesso: 29.08.2011.
} 
Não apenas a ABRAED questionou o entendimento do STF por intermédio dos embargos de declaração, alegando que existe uma preocupação de as empresas privadas continuarem sendo perseguidas pela ECT - em entrevista junto à associação foi afirmado que continua ocorrendo uma perseguição, ainda que em menor escala - como também persistem outras discussões, como da entrega de contas. Neste sentido, segundo notícia posteriormente publicada ${ }^{250}$, a discussão sobre o "monopólio" dos Correios voltará ao STF, em vista de decisões dos Tribunais Regionais Federais que autorizaram que faturas de energia elétrica e contas de água e esgoto sejam entregues diretamente aos consumidores, afastando qualquer exclusividade da ECT sobre isso.

Deveras, conforme a notícia, decisão do Tribunal Regional Federal da $5^{\text {a }}$ Região teria conferido à ENERGISA, distribuidora de energia que atua nos Estados de Sergipe, Minas Gerais e Paraíba, a possibilidade de entregar suas faturas diretamente aos consumidores, e o Tribunal Regional Federal da $1^{\text {a }}$ Região teria permitido que o Serviço Autônomo de Água e Esgoto de Lagoa da Prata (SAAE), de Minas Gerais, entregue contas de água e esgoto diretamente aos consumidores logo após a realização da leitura do hidrômetro. O pronunciamento do STF que delimita de maneira incerta o campo de serviços não "monopolizados", assim, revelou-se na prática insuficiente para minimizar os conflitos no setor e, pois, funcionalmente inadequado.

\section{V.3.3.2. Correlação entre serviço público e prestação "monopolista"}

Além de ter delimitado de maneira incerta o campo de serviços não "monopolizados", no julgamento da ADPF n. 46-7/DF em grande medida foi feita uma correlação entre a natureza de serviço público do serviço postal e sua prestação "monopolista".

Nesse sentido, em seu voto condutor, o ministro Eros Grau, partindo de uma concepção de Estado intervencionista, afirma que o serviço postal não é atividade econômica em sentido estrito, explorada por empresas privadas, mas sim serviço público por definição constitucional, que deve ser prestado exclusivamente pela União em regime de privilégio (regime de "monopólio" dos serviços públicos), de modo que a ECT atua e deve atuar em regime de exclusividade na prestação dos serviços que lhe incumbem. A esse respeito entende o ministro: “Os regimes jurídicos sob os quais são prestados os

\footnotetext{
${ }^{250}$ Cf. notícia "Monopólio dos Correios voltará à pauta do STF".
} 
serviços públicos importam em que sua prestação seja desenvolvida sob privilégios, inclusive, em regra, o da exclusividade na exploração da atividade econômica em sentido amplo a que corresponde a sua prestação. É justamente a virtualidade desse privilégio de exclusividade na prestação, aliás, que torna atrativo para o setor privado a sua exploração, em situação de concessão ou permissão" ${ }^{\text {251. }}$.

De maneira semelhante posicionou-se a ministra Ellen Gracie, segundo a qual, tratando-se o serviço postal de serviço público, não podem lhe ser aplicados os princípios da livre concorrência e da livre-iniciativa. Trata-se de serviço que o constituinte confiou à União para que mantivesse, com exclusividade, serviço que a União tem o dever de prestar em todo o território nacional e que exercita por delegação legal a uma empresa pública expressamente constituída para tal finalidade ${ }^{252}$.

No mesmo sentido foi a manifestação da ministra Cármen Lúcia, de acordo com a qual: "Vou acompanhar a divergência, Ministro, por entender que o que foi posto, ao iniciar a divergência, pelo Ministro Eros Grau, rigorosamente no sentido de ser serviço público, como diria Pontes de Miranda, assim o é porque a Constituição assim o quer: que o serviço postal e o correio aéreo nacional sejam de competência da União e, nessa condição, exclui da submissão obrigatória os princípios que foram listados pela argüente neste caso, que seriam da livre-iniciativa e da livre concorrência, exatamente porque o regime jurídico aqui é diferenciado" 253.

Embora os ministros tenham entendido que a prestação de serviços públicos se desenvolve sob privilégios, em regra, o da exclusividade na exploração da atividade econômica em sentido amplo a que corresponde a sua prestação, esta correlação entre a natureza jurídica de serviço público do serviço postal e sua prestação em regime de privilégio é bastante questionável. Essa análise, justificada na leitura literal do verbo “manter" da Constituição e em análises bastante alinhadas a concepções políticas dos ministros de qual é o melhor modelo de Estado (se mais ou menos intervencionista) ${ }^{254}$, acaba, no entanto, não analisando de maneira consistente se efetivamente uma dada atividade que tem a natureza jurídica de serviço público necessariamente será prestada em regime de exclusividade.

\footnotetext{
${ }^{251} \mathrm{ADPF} \mathrm{n.}^{\text {o }}$ 46-7/DF, p. 90.

${ }^{252}$ ADPF n. ${ }^{\circ}$ 46-7/DF, p. 120-123.

${ }^{253}$ ADPF n. ${ }^{\circ}$ 46-7/DF, p. 137.

${ }^{254}$ Certamente cada ministro tem suas ideologias, o problema é quando eles não as deixam transparentes.
} 
Deveras, a intervenção direta do Estado na economia não se resume à assunção monopolística da exploração de atividades econômicas, pois o Estado pode assumir a produção de bens e serviços diretamente (no caso, por intermédio de uma empresa estatal), sem interditar a exploração dessas atividades aos particulares. O fato de uma determinada atividade passar a se submeter ao regime de direito público, por ter sido eleita à condição de serviço público, não implica, pois, sua retirada do domínio econômico, a exploração exclusiva pelo Estado ${ }^{255}$.

Isso não significa que o poder público deixará de ter a titularidade dos serviços, restringindo o acesso à sua exploração pela iniciativa privada, através da outorga de concessões e permissões, e exigindo que sua exploração se sujeite a um regime submetido mais fortemente ao direito público, mas não necessariamente implicará no dever ou na prerrogativa de exploração exclusiva.

Mas há ainda outra questão, de saber se as atividades postais são "monopólios" naturais, de acordo com a conceituação econômica, caso em que o mercado absorveria apenas a oferta de uma única empresa em dado nível de produção. Tal como analisado no Capítulo 2 (item IV.4), é possível que no passado o setor postal tivesse características de monopólio natural, mas atualmente é visível que o setor acomoda empresas privadas, que produzem em escala viável. Em alguma medida, o setor, portanto, funciona em condições concorrenciais, pelo que incabível falar que as condições estruturais e tecnológicas da prestação dos serviços postais impedem sua organização em regime competitivo.

Esse aspecto mais econômico da análise das características do setor, no entanto, não fez parte das razões de decidir da corrente majoritária de ministros do STF, embora eles tenham se manifestado sobre a exclusividade da prestação dos serviços postais, relacionando-a inclusive à natureza jurídica de serviço público. O único ministro que procurou analisar se os serviços postais constituem ou não "monopólios" naturais (“privilégios naturais") foi Marco Aurélio, voto vencido. Partindo de uma concepção segundo a qual o Estado interventor é ineficiente, devendo ser substituído pelo Estado

${ }^{255}$ A esse respeito, ver Floriano de Azevedo Marques Neto, "A nova regulação dos serviços públicos", Revista de Direito Administrativo, v. 228, p. 20-22. Ver também Carlos Ari Sundfeld, "Introdução às agências reguladoras". In: SUNDFELD, Carlos Ari (coord.). Direito administrativo econômico, p. 32. Segundo este autor, uma das razões que fazem com que a noção de serviço público não seja mais útil, ao menos não da forma como era no passado, “...é que o conceito ficou excessivamente vinculado a um dado modelo econômico de exploração do serviço, que está sendo abandonado em todo o mundo, no Brasil inclusive, caracterizado especialmente pela exploração monopolista, não-concorrencial, por meio de empresas estatais". 
gerencial, que atua de forma apenas subsidiária, o ministro argumenta que o serviço postal durante muito tempo não foi apenas mantido pela União, como também foi por ela executado, porque não havia no país empresas com capacidade técnica e operacional para desenvolvê-los.

Neste sentido, o ministro afirma: "O serviço postal, durante muito tempo, foi executado pela União - e não somente mantido - porque simplesmente não havia no País empresas com capacidade operacional e técnica suficientes para poder desenvolver, com presteza e agilidade, a entrega de correspondências por todo o território nacional. As dimensões continentais brasileiras, atreladas aos incipientes investimentos nos transportes - aéreo, terrestre, ferroviário -, forçaram o surgimento de um monopólio inevitável. As precárias condições vigentes à época não admitiam o ingresso de empresas privadas" ${ }^{256}$.

Inexistente uma exclusividade automática e a imperatividade da prestação direta, surge um maior ônus argumentativo por parte daqueles que defendem que os Correios devem atuar "monopolisticamente", debate que, no entanto, não foi explorado no julgamento da ADPF n. ${ }^{\circ}$ 46-7/DF. Essa análise surge na decisão de maneira bastante isolada (especificamente no voto vencido do ministro Marco Aurélio), não tendo o STF propriamente discutido o tema da existência ou não do "monopólio" natural.

\section{V.3.3.3. Correlação entre "monopólio" e universalização}

Outra correlação bastante discutível que surgiu no julgamento da ADPF n. ${ }^{\circ}$ 467/DF relaciona-se à exclusividade na prestação do serviço para sua prestação universal. A esse respeito, a ECT alega que a receita dos serviços "monopolizados" é fundamental para que subsidie a prestação dos serviços em locais deficitários (47\% da receita operacional da estatal adviria das atividades "monopolizadas" ${ }^{, 257}$ ). Essa prática, conhecida na literatura econômica como subsídio cruzado, muitas vezes é utilizada para legitimar o regime "monopolista" da estatal.

\footnotetext{
${ }^{256}$ ADPF n. ${ }^{\circ} 46-7 / \mathrm{DF}$, p. 54.

${ }^{257} \mathrm{O}$ dado de $47 \%$ encontra-se em manifestação da ECT no bojo do julgamento da ADPF n. ${ }^{\circ}$ 46-7/DF. Os números veiculados no "Relatório Empresarial e Social da ECT 2008" são ainda maiores: "Na composição do seu faturamento, aufere $58 \%$ da sua receita dos serviços monopolizados (carta, telegrama e correspondência agrupada), de modo que a reserva de mercado desses três serviços é fator essencial para a sobrevivência e para a garantia da universalização". Disponível em:

$<$ http://www.correios.com.br/institucional/conheca_correios/relatorios_publicacoes/relatorios_empresariais/2 008/Relatorio_ECT_2008.pdf>. Acesso: 21.06.2010.
} 
Por essa linha de argumentação, tais serviços "monopolizados", na condição de superavitários, compensariam os deficitários dentro do próprio setor, sem onerar o poder público, o Tesouro Nacional, dado a ECT tratar-se de empresa estatal não dependente ${ }^{258}$. Por trás da formulação desse argumento está a concepção segundo a qual a ECT, ao prestar atividades econômicas, não visa o lucro em si, mas sim as fontes de financiamento para o serviço público.

No julgamento da ADPF n. ${ }^{\circ}$ 46-7/DF, alguns ministros se valeram dessa linha de argumentação para justificar o regime de exclusividade na prestação de serviços postais conferido à ECT. Neste sentido, em seu voto, o ministro Joaquim Barbosa (corrente majoritária) argumentou que as empresas privadas, filiadas à ABRAED, não pretendem operar em todas as áreas em que a ECT atua, mas somente na entrega de documentos comerciais, setor mais lucrativo e de maior interesse econômico. Além disso, a atuação das empresas privadas não estaria voltada a todo o território nacional, uma vez que seu trabalho restringe-se às grandes cidades e capitais do país, não alcançando municípios pequenos e distantes do centro econômico nacional ${ }^{259}$. Diante dessa argumentação, embora o ministro não fale expressamente, está o entendimento segundo o qual, para que a ECT tenha condições de seguir prestando diversos serviços ao longo de todo o país, há de ser dotada de um regime jurídico em certa medida privilegiado, sendo necessária inclusive a exclusividade na prestação de alguns serviços (lucrativos, como é o caso das correspondências comerciais).

\footnotetext{
${ }^{258}$ As empresas estatais têm sido classificadas em "dependentes" e "não dependentes", com base na Lei de Responsabilidade Fiscal (Lei Complementar n. ${ }^{\circ}$ 101/00), que as separa em duas categorias de empresas: (i) aquelas que necessitam de subvenções econômicas para sobreviver (as "dependentes"); e doutro lado (ii) as capazes de por si só custear suas despesas (as "não dependentes", que a lei denominou de "controladas"). A situação de "dependência", portanto, é eminentemente econômica, relacionada à cobertura dos déficits de manutenção das estatais. Pressupõe certa comunicação entre os orçamentos do ente controlador e da empresa controlada (para pagamento de despesas com pessoal ou de custeio em geral ou de capital), como se fosse desconsiderada a personalidade jurídica da estatal, que não consegue ser propriamente dotada de autonomia financeira e gestão patrimonial próprias. Sobre o tema, ver Carlos Ari Sundfeld; Rodrigo Pagani de Souza. “A superação da condição de empresa estatal dependente", Revista de Direito Público da Economia, n. 12. ${ }^{259}$ ADPF n. ${ }^{\circ} 46-7 / \mathrm{DF}$, p. 108-110.
} 
Também a ministra Ellen Gracie se vale dessa linha de argumentação. Entende que por ser o serviço público informado pelo princípio da supremacia do interesse público é que ele é mantido ainda em condições deficitárias, “...como é o caso da entrega de correspondências em locais remotos e de difícil acesso de nosso vasto território nacional. Garantir condições de comunicabilidade e de remessa de mensagens ou objetos a todos os brasileiros é objetivo que responde a mais do que o simples interesse individual dos missivistas. Diz respeito aos superiores interesses da integração nacional ${ }^{260}$.

Posição semelhante também foi adotada pelo ministro Nelson Jobim. Em face do posicionamento inicial do ministro Carlos Britto, segundo o qual não integraria a exclusividade da atividade da União aquilo que tiver caráter rigorosamente mercantil, comercial - a exclusividade seria restrita às atividades que impliquem comunicação privada e telegráfica -, travou-se uma discussão com o ministro Nelson Jobim, na qual este tentou contra-argumentar com Carlos Britto partindo da questão do subsídio cruzado. Questiona Nelson Jobim, "A parte rentável, que financia a entrega de cartas, pode ser privatizada?", ao que responde Carlos Ayres: "Não entendi bem". Nelson Jobim então mostra seu ponto de vista divergente, tendo por pano de fundo a questão da universalização: "Porque o mecanismo tem financiamento cruzado, ou seja, se tira a parte rentável da empresa, inviabiliza-se a outra", ao que Carlos Britto responde: "Digo o seguinte, o que tiver caráter nitidamente mercantil, eu excluiria. Julgo procedente em parte ${ }^{261}$.

Posteriormente, o ministro Carlos Britto justifica sua alteração de posicionamento exatamente por conta dessa questão da necessidade de ter-se o subsídio cruzado para a prestação universal dos serviços postais pela ECT. Segundo o ministro Carlos Britto, “...quando eu fiz aquele primeiro voto, eu tive o cuidado de explicitar que se tratava de um tema de difícil cognição, não só na prática, extremamente complexo, que levava a divergências radicais. Como à luz do próprio Direito, todos nós tínhamos dificuldade em precisar o alcance material dessa dicção constitucional 'serviço postal'. Está bem claro no meu primeiro voto. Depois disso, a Ministra Ellen Gracie trouxe um substancioso voto que me impressionou bastante, entre outras coisas, porque Sua Excelência falava de financiamento cruzado, dizendo que as receitas do serviço público, prestado pelos

${ }^{260}$ ADPF n. ${ }^{46-7 / D F, ~ p . ~} 122$.
${ }^{261}$ ADPF n. ${ }^{\circ}$ 46-7/DF, p. 113. 
Correios e Telégrafos, se compensam, de sorte que algumas financiam outras" ${ }^{\text {262 }}$. E prossegue o ministro: “...Assentei o regime juspublicístico do serviço e não o jusprivatístico, na linha do voto do Ministro Eros Grau"263.

Embora esse tema do subsídio cruzado para a prestação universal dos serviços postais tenha surgido no julgamento, a análise feita pelos ministros foi bastante superficial. Não houve uma preocupação efetiva com a análise crítica do quanto o discurso da ECT de que a receita dos serviços "monopolizados" é fundamental para que subsidie a prestação dos serviços em locais deficitários é consistente.

O subsídio cruzado é de fato necessário para manter o setor? Como é na prática, concretamente, a política tarifária utilizada pela ECT? Por quais regiões do país estão distribuídos os ativos da ECT (o fato de, por exemplo, a maior parte dos ativos da empresa estar em lugares mais ricos pode constituir um problema para a concretização desse discurso oficial)? Qual a relação entre os ativos, o número de atendimentos e o volume de depósitos (faturamento) do setor? A empresa tem uma classificação de quais são os serviços superavitários e deficitários? Em suma, como funciona, concretamente, o subsídio cruzado dos serviços postais? Qual é o papel das Agências de Correio Comunitárias na busca da universalização e como elas são operadas (por meio dessas agências são prestados serviços básicos às mais diversas localidades do país, mas essas agências são terceirizadas)?

Essas são algumas das questões que certamente enriqueceriam as discussões sobre a necessidade de manutenção do "monopólio" postal em vista do tema da universalização do setor, mas que ficaram em aberto quando do julgamento da ADPF n. ${ }^{\circ}$ 46-7/DF. Mais do que isso, o tema foi tratado em posicionamentos isolados dos ministros do STF - que claramente manifestaram uma preocupação em proteger a ECT -, não tendo sido objeto de discussões efetivas por parte deles, razão pela qual esses pronunciamentos são incapazes de gerar um posicionamento da instituição STF como um todo.

${ }^{262}$ ADPF n. ${ }^{\circ} 46-7 / \mathrm{DF}$, p. 174.

${ }^{263}$ ADPF n. ${ }^{\circ} 46-7 / \mathrm{DF}$, p. 175. 
Ademais, tal como chamou atenção o ministro Marco Aurélio (voto vencido), a controvérsia sobre os custos de universalização da atividade não necessariamente é resolvida através do mecanismo do subsídio cruzado $^{264}$. Deveras, essa prática do subsídio cruzado, embora possa legitimar o regime "monopolista" da estatal, ao mesmo tempo pode gerar grandes distorções concorrenciais (além de ser um mecanismo de difícil controle) e, em vista disso e do próprio processo de privatizações verificado nas últimas décadas, vêm sendo criados outros mecanismos para propiciar que os usuários potenciais marginalizados do sistema, pouco atrativos para as operadoras privadas, passem a ter acesso aos serviços.

Como o próprio ministro Marco Aurélio aponta, no setor de telecomunicações, por exemplo, foi criado um fundo, denominado Fundo de Universalização do Setor de Telecomunicações (FUST). Mais precisamente, a Lei Geral de Telecomunicações (LGT), lei n. ${ }^{\circ} 9.472$ de 16 de julho de 1997, ao servir de lei-quadro para a reformulação do setor de telecomunicações do Brasil, previu três mecanismos de universalização: (i) a obrigação dos prestadores dos serviços de telecomunicações em regime público cumprirem metas de universalização (artigos 79 e 80), (ii) os recursos complementares destinados a cobrir a parcela do custo exclusivamente atribuível ao cumprimento das obrigações de universalização de prestadora de telecomunicações, que não possa ser recuperada com a exploração eficiente do serviço, os quais poderão ser oriundos (ii.1) do Orçamento Geral da União, dos Estados, do Distrito Federal e dos Municípios (art. 81, I); e (ii.2) de fundo especificamente constituído para essa finalidade, para o qual contribuirão prestadoras de serviço de telecomunicações nos regimes público e privado, nos termos da lei. A previsão da LGT foi regulamentada por meio da edição da lei n. ${ }^{\circ}$ 9.998/00 (Lei do FUST), que instituiu o Fundo de Universalização dos Serviços de Telecomunicações (FUST), e do decreto n. ${ }^{\circ}$ 3.624/00, que dispõe sobre a regulamentação do Fundo.

Embora a LGT expressamente preveja a possibilidade de recursos complementares para cumprimento das obrigações de universalização dos serviços de telecomunicações serem oriundos do Orçamento Geral dos entes federativos, certamente esta fonte de recursos não pode ser vista como principal ou exclusiva. Na medida em que o processo de reorganização do setor se deu com a finalidade de reduzir a atuação direta do Estado, e tendo em vista que a reforma do Estado brasileiro relaciona-se em grande medida com as constrições de caráter fiscal, a utilização dos recursos orçamentários dos entes federativos tem sem dúvida um papel secundário como fonte de receita para a universalização do setor

${ }^{264}$ ADPF n. ${ }^{\circ} 46-7 / D F$, p. 74. 
de telecomunicações ${ }^{265}$. Portanto, na sistemática da LGT, outros mecanismos de financiamento que não a utilização de recursos orçamentários devem ser buscados.

Disso advém a importância, por exemplo, da previsão pela LGT da criação de fundo especificamente constituído para servir de recurso para cumprimento das obrigações de universalização (art. 81, caput e inciso II). Para sua constituição contribuem todas as prestadoras de serviços de telecomunicações nos regimes público e privado, nos termos da lei (art. 81, II). Seus recursos, conforme prevê a LGT, devem ser destinados a cobrir a parcela do custo da prestadora de serviços de telecomunicações que não possa ser recuperada com a exploração eficiente do serviço (art. 81, caput). O fundo se destina a universalizar serviços de telecomunicações que não sejam obrigação das prestadoras, mas que sejam considerados necessários ou desejáveis. É dizer, uma vez formuladas as políticas públicas para a aplicação dos recursos do FUST, e definidos os serviços como públicos (pela LGT e Lei do FUST, os recursos estão atrelados aos serviços prestados em regime público, conforme definido no Plano Geral de Outorgas - PGO) e, pois, submetidos a obrigações de universalização e continuidade, os recursos do fundo podem ser utilizados como mecanismo para se obter a universalização.

Bem é verdade que atualmente o FUST tem tido problemas relacionados à sua operacionalização e utilização, mas, por tratar-se de mecanismo de universalização em cenário concorrencial, poderia ao menos ter sido mais bem avaliado pelo Tribunal quando se pronunciou favoravelmente à recepção do "monopólio" legal, e certamente é ponto importante a ser tratado numa reestruturação da legislação aplicável ao setor. Quer dizer, a prática de subsídio cruzado não é o único meio de obter-se a universalização dos serviços postais, sendo possível e eficiente avaliar os prós e contras dos mecanismos existentes, com vistas a inclusive aferir-se a funcionalidade de recepcionar-se o "monopólio" postal. Nesse sentido é que é importante que se avalie o impacto da adoção da prática do subsídio cruzado e da criação de fundos setoriais no setor.

\footnotetext{
265 Cf. Alexandre Ditzel Faraco; Caio Mário da Silva Pereira Neto; Diogo Rosenthal Coutinho, "Universalização das telecomunicações no Brasil: uma tarefa inacabada", Revista de Direito Público da

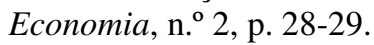


Não apenas o mecanismo do FUST coloca em xeque o pressuposto do qual parte a corrente majoritária dos ministros, de que a prestação universal é alcançada a partir de um regime de exclusividade. A princípio, nem a lógica da prestação de serviços públicos não monopolizados é contrária à universalização, nem a lógica da concorrência o é. Ambas as lógicas poderão vir a ser obstáculos à universalização dependendo da forma como o setor for regulado. $\mathrm{O}$ setor de telecomunicações também é bom exemplo disso. Mesmo os serviços prestados em regime privado (e, portanto, não atingíveis pelos recursos oriundos do FUST), caso da telefonia celular, tiveram uma penetração muito grande junto à sociedade. Neste setor, conforme afirmam Alexandre Ditzel Faraco, Caio Mário da Silva Pereira Neto e Diogo Rosenthal Coutinho ${ }^{266}$ criou-se um ambiente fortemente concorrencial (a partir de um duopólio no setor, com duas prestadoras para cada área geográfica), que reduziu os preços de maneira bastante significativa e levou as prestadoras a oferecerem novas formas de contratação do serviço (como o celular pré-pago).

Assim, a análise da questão da universalização claramente vai muito além de referências à aplicação do mecanismo de subsídio cruzado aos serviços prestados pela ECT, como se ele fosse per se eficaz, consistente e adequado, independentemente de qualquer análise do seu funcionamento e necessidade para manter o setor, inclusive em vista de outras possibilidades existentes (e da avaliação de seus prós e contras). Há ainda espaço para muitas discussões críticas serem travadas para a formulação e implementação de políticas públicas voltadas à universalização do serviço postal, seja no âmbito do Judiciário, especificamente do STF, seja no âmbito do Legislativo, do Ministério das Comunicações e da ECT, e ainda em outras esferas públicas ou privadas ${ }^{267}$.

266 Cf. Alexandre Ditzel Faraco; Caio Mário da Silva Pereira Neto; Diogo Rosenthal Coutinho, "Universalização das telecomunicações no Brasil: uma tarefa inacabada", Revista de Direito Público da Economia, n. ${ }^{\circ}$ 2, p. 35 .

${ }^{267}$ Em relação ao tema da universalização no setor postal, a presente pesquisa procura chamar atenção somente para a insuficiência do seu tratamento, especialmente na jurisprudência do STF. Foge ao objeto deste trabalho tratar com profundidade deste tema que, por si só, merece um estudo à parte. Para uma análise aprofundada do tema da universalização, ver Diogo Rosenthal Coutinho, "A universalização do serviço público para o desenvolvimento como uma tarefa da regulação". In: SALOMÃO FILHO, Calixto (coord.). Regulação e desenvolvimento, p. 65-86. Ver também, do mesmo autor, "Entre eficiência e eqüidade: a universalização das telecomunicações em países em desenvolvimento", Revista Direito GV, v. 2, p. 137-160. 


\section{V.3.3.4. Contradição entre a natureza jurídica de serviço público da rede postal e a decisão final da ADPF}

Mas a decisão do STF deixa em aberto ainda outras questões centrais para o debate sobre o setor. Adotado o entendimento amplamente consolidado pelo STF (inclusive na ADPF n. $\left.{ }^{\circ} 46-7 / D F\right)$ de que o serviço postal como um todo é serviço público (partindo da dicotomia serviços públicos versus atividades econômicas) as empresas privadas não poderiam atuar livremente nem na área do "monopólio" (seja lá qual for o seu alcance) nem nas áreas não "monopolizadas".

Apesar disso, embora da decisão final da Corte se possa extrair outro entendimento, não se vê nos votos uma clara preocupação em se diferenciar a natureza jurídica das atividades que a ECT presta conferindo-lhes um regime jurídico diferente. Tampouco a Corte retirou dos "serviços postais" (serviço público) as atividades competitivas (impressos e encomendas). Nem deu aos "serviços públicos" uma interpretação ampla que englobe atividades relevantes e de interesse público, independentemente do regime por meio do qual eles são prestados. Diante disso, parece haver uma contradição entre a natureza jurídica de serviço público de toda a rede postal e a decisão final da ADPF.

Ao final da decisão o STF deu interpretação conforme ao art. 42 da lei n..$^{\circ}$ 6.538/78 (que criminaliza a violação do privilégio postal da União) para restringir sua aplicação às atividades postais descritas no art. $9^{\circ}$ da lei (ao qual nem sempre é fácil subsumir as atividades postais atualmente prestadas, como visto). O que essa decisão significou em termos práticos (as consequências da decisão do STF) ficou num plano bastante secundário.

Em seu voto condutor da corrente majoritária, o ministro Eros Grau, partindo da dicotomia serviços públicos versus atividades econômicas, claramente afirma que “...a premissa de que parte a argüente é equívoca. O serviço postal não consubstancia atividade econômica em sentido estrito, a ser explorada pela empresa privada"268. Por essa linha de raciocínio, sobre todas as atividades postais é aplicável o regime de serviço público, sendo que algumas são prestadas pela ECT em regime de exclusividade (privilégio). Neste sentido, o ministro chega a afirmar que “...para que empresa privada pudesse ser admitida à prestação do serviço postal, que é serviço público, seria necessário que a Constituição dissesse que o serviço postal é livre à iniciativa privada, tal qual o

${ }^{268}$ ADPF n. ${ }^{\circ} 46-7 / \mathrm{DF}$, p. 88. 
fazem os artigos 199 e 209 em relação à saúde e à educação, os quais podem ser prestados independentemente de concessão ou permissão. Os artigos mencionados excepcionam o art. 175 para dizer que a prestação de serviços de saúde e educação são livres à iniciativa privada"269.

Seguindo essa linha de raciocínio, não apenas é lícito criminalizar-se as empresas privadas que atuam na área de privilégio da ECT (art. $9^{\circ}$ c/c art. 42 da lei n. ${ }^{\circ}$ 6.538/78), como também as empresas privadas que convivem competitivamente com a ECT, sem qualquer vínculo de outorga ou parceria com a estatal, e mesmo as franquias postais, outorgadas sem prévio procedimento licitatório. Seria admissível a prestação dos serviços postais apenas pela ECT e concessionárias e permissionárias do setor. Apesar disso, em seu voto, o ministro - assim como a grande maioria dos que o acompanharam - apresenta seus entendimentos de forma desconexa em relação à realidade do setor.

Uma interpretação mais funcional em vista da complexa realidade do setor foi sinalizada pelo posicionamento inicial, intermediário, do ministro Carlos Britto, segundo o qual o cerne da questão é que o serviço postal é serviço público, mas há atividades prestadas como postais que não podem ser englobadas como serviços postais, pelo que estariam fora do conceito de serviço público, podendo ser livremente prestadas pela iniciativa privada, independentemente de qualquer vínculo de outorga. Ocorre que esse seu posicionamento inicial no sentido de excluir do conceito de serviço postal as encomendas e os impressos não se coaduna com a posição majoritária à qual o ministro ao final do julgamento se filiou, que não exclui nenhum serviço prestado como postal do âmbito dos serviços públicos.

Na medida em que ao final do julgamento o STF deu interpretação conforme ao art. 42 da lei n. ${ }^{\circ} 6.538 / 78$ para restringir sua aplicação às atividades postais descritas no art. $9^{\circ}$ da lei, e as empresas privadas seguem funcionando normalmente, na prática pode-se interpretar que o Tribunal excluiu impressos e encomendas não apenas do regime de exclusividade conferido à ECT, como também do regime de serviço público. Isso foi aferido não apenas da prática setorial, como também das entrevistas realizadas junto ao Ministério das Comunicações, à ABRAED e à ABRAPOST-SP. As empresas privadas estariam, assim, autorizadas a explorar as atividades relacionadas a impressos e encomendas livremente, em regime de mercado, mas o Tribunal, como já visto, não precisou claramente o que isso significa em termos práticos. Outra interpretação da decisão

${ }^{269}$ ADPF n. ${ }^{\circ} 46-7 / \mathrm{DF}$, p. 90. 
final da $\mathrm{ADPF}$ n. ${ }^{\circ}$ 46-7/DF leva a uma completa desconexão com a realidade de prestação dos serviços postais.

Em certa medida, alguns posicionamentos isolados dos ministros do STF chamaram atenção para a necessidade de o Tribunal dar uma decisão conexa com a realidade de prestação dos serviços. Significativa a esse respeito foi a discussão travada entre os ministros Gilmar Mendes e Marco Aurélio. Ao longo do julgamento, o ministro Gilmar Mendes sinaliza uma clara preocupação com o distanciamento da lei em vista da realidade de prestação dos serviços por empresas privadas.

A este respeito, manifesta-se no seguinte sentido: "Em relação à questão da recepção ou não, assumo uma posição intermediária, propondo uma interpretação conforme. Eu até bosquejava a idéia de que esta norma da Lei de 78 era compatível com a Constituição anterior. Parece que a própria evolução social e econômica estaria a sinalizar, aqui, um tipo de processo de inconstitucionalização. A própria dinâmica, hoje, dos serviços estaria a indicar a participação dos atores privados e uma certa obsolescência dos dispositivos, pelo menos se lidos na sua literalidade estrita. Eu não consigo imaginar, por exemplo, que nós possamos invocar essa idéia do serviço público monopolístico para a entrega dos jornais, que se faz em geral, hoje, às cinco horas da manhã, e dizer que toda essa atividade, hoje realizada por empresas privadas, tivesse que ser desempenhada exclusivamente pela Empresa Brasileira de Correios e Telégrafos. Parece que isso está sendo revisto pela realidade, imaginando a sociedade aberta dos intérpretes da Constituição"270. A essas ideias o ministro Marco Aurélio acrescenta: "De reserva de mercado" 271 .

A partir disso, trava-se uma discussão entre os ministros Gilmar Mendes e Marco Aurélio $^{272}$, voltada a este problema da realidade setorial, discrepante da legislação, ou ao menos da interpretação que lhe tem sido dada. Diz Gilmar Mendes, complementando a ideia de Marco Aurélio: "Sim; ou a dizer que todas essas atividades que se exercem universalmente no Brasil são exercidas de forma ilícita, porque essa seria a outra conclusão". Completa Marco Aurélio: “Exato. Se assentado o monopólio, a exclusividade, de forma linear quanto à Empresa Brasileira de Correios e Telégrafos, na prestação de serviço, ter-se-á a clandestinidade". Gilmar Mendes: "Quer dizer, se essa atividade é

\footnotetext{
${ }^{270}$ ADPF n. ${ }^{\circ}$ 46-7/DF, p. 129.

${ }^{271}$ ADPF n. ${ }^{\circ}$ 46-7/DF, p. 129.

${ }^{272}$ ADPF n. ${ }^{\circ}$ 46-7/DF, p. 129-131.
} 
ilícita, é clandestina, teremos que ver. Veja, realmente frustrando uma atividade que é dinâmica, e ninguém imagina que seja necessária para a sociedade, pelo contrário, nós perderíamos talvez a eficiência". Marco Aurélio: "No que nós outros, acatando esse serviço, estaríamos contribuindo para a ilegalidade". Gilmar Mendes: "Se era de fato legítimo e constitucional, condizente até com o modelo anterior da Constituição, parece que a dinâmica dos tempos, a própria atividade plural do mercado fez um tipo de processo de inconstitucionalização”. Gilmar Mendes: “...É o tipo de tema que está a demandar ou uma completa reinterpretação ou uma reconfiguração pelo legislador daquilo que se entende de manutenção do serviço postal. (...) Então, queria assentar essa conclusão provisória e essa perplexidade".

Ainda que alguns posicionamentos isolados dos ministros do STF revelem uma preocupação de alinhar o posicionamento do Tribunal com a complexa realidade de prestação dos serviços no setor, claramente não se vê no julgamento como um todo, e especialmente na corrente majoritária que prevaleceu, uma preocupação institucional de se conectar a decisão da Corte com a realidade de prestação dos serviços postais. De fato, em seus votos, os ministros Eros Grau, Joaquim Barbosa, Cezar Peluso, Ellen Gracie, Cármen Lúcia e Carlos Britto não se manifestaram de maneira consistente sobre a realidade de prestação dos serviços, em certa medida desconsiderando-a, como se as respostas que o Tribunal dá aos jurisdicionados fossem claramente extraídas tão somente da legislação e dos entendimentos doutrinários.

Nesse sentido, diante da complexa realidade setorial, a ministra Cármen Lúcia assim se manifesta: "Farei juntar voto no sentido de acompanhar integralmente a expressão do Ministro Eros Grau, com a devida desculpa do Ministro-Relator. Mesmo com as ponderações de Vossa Excelência, quanto à dinâmica da vida, principalmente dessas novas formas de comunicação, eu diria que a Constituição não é imutável, pode ser mudada, que a própria lei, naquilo que ela especificamente estipulou como podendo ser, ou não cabendo no caso do artigo $9^{\circ}$, pode ser repassada por outra, mas, considerar não recepcionada nem dar interpretação conforme, não estou convencida disso ${ }^{, 273}$.

Em seu voto, o ministro Carlos Britto revela um desconhecimento da realidade do setor e, pois, uma desconexão entre sua atividade judicante e a prática. A esse respeito, diante do seu posicionamento final de que encomendas e impressos não são serviços exclusivamente prestados pela ECT, os advogados da empresa manifestaram-se dizendo 
que esses serviços não são prestados em regime de exclusividade (o que inclusive se extrai da própria legislação e da manifestação da ECT), ao que Carlos Britto, surpreso, afirma que nem sabia que na prática isso já estava excluído.

Diz o ministro Carlos Britto, em passagem anteriormente transcrita: “...Assentei o regime juspublicístico do serviço e não o jusprivatístico, na linha do voto do Ministro Eros Grau. Eu nem sabia que na prática isso já estava excluído. Excluí, como efetivamente excluo, do âmbito material de incidência desta expressão 'serviço postal', os impressos, a partir do voto de Vossa Excelência, proferido anteontem, e contemplo aquela minha primeira preocupação: também afasto do âmbito de incidência as encomendas, ou seja, os volumes entregues para destinação a terceiros. Então, excluiria exclusivamente do meu voto ou do âmbito de incidência material dessa expressão constitucional 'serviço postal' tão-só os impressos e as encomendas" ${ }^{274}$.

Apenas em alguns votos isolados dos ministros, especificamente de Gilmar Mendes e Marco Aurélio, é que foi dada alguma importância à realidade do setor. Não apenas os ministros discutiram entre si esse aspecto, discussão abordada linhas atrás, como também em seus votos eles atribuíram alguma importância a esta questão. O ministro Gilmar Mendes, por exemplo, afirmou que a lei n. ${ }^{\circ} 9.074 / 95$ (art. $1^{\circ}$, VII) dispõe que os serviços postais se sujeitam ao regime de concessão ou quando couber de permissão, razão pela qual a delegação do serviço postal é admissível, desde que o legislador assim discipline. Em relação a este aspecto, porém, o ministro não chegou a mencionar as já existentes agências permissionárias no setor.

O ministro observou ainda que o modelo de franquia postal é tratado na legislação (lei n. ${ }^{\circ} 11.668 / 08$ e decreto n. $\left.{ }^{\circ} 6.639 / 08\right)$, de modo que, segundo entende, "Evidentemente, a franquia postal não se confunde com a clássica concessão e permissão de serviço público, o que já revela que o legislador pode dispor sobre a execução do serviço postal para além das hipóteses do art. 175, da CF, desde que respeitados os princípios

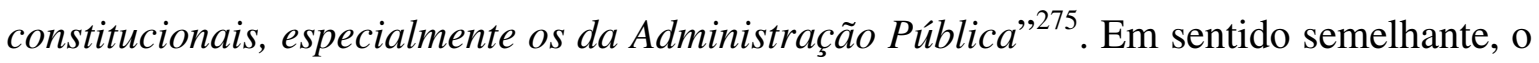
ministro Marco Aurélio em seu voto afirmou que o sistema de franquias do Brasil reforça a argumentação de que embora o art. 175 da Constituição proíba a delegação de serviço público sem que seja precedida de licitação, a ECT realizou entre 1990 e 1994 quase dois mil contratos de franquia, talvez por perceber que não se tratava mais de serviço público.

\footnotetext{
${ }^{274}$ ADPF n. ${ }^{\circ}$ 46-7/DF, p. 175.

${ }^{275}$ ADPF n. ${ }^{\circ}$ 46-7/DF, p. 214-215.
} 
Pode-se afirmar, assim, que a conexão com a realidade setorial teve um papel secundário no julgamento, tendo em grande medida sido atribuída apenas ao legislador, como se também não fosse tarefa do Tribunal ao menos minimizar os conflitos no setor, conferindo-lhe maior segurança jurídica. Com relação a este aspecto, em passagem citada, a ministra Cármen Lúcia chamou atenção para o fato de que, em vista da dinâmica da vida, principalmente dessas novas formas de comunicação, a Constituição e a legislação podem ser mudadas, não cabendo ao Tribunal considerar a lei não recepcionada ou dar-lhe interpretação conforme. O ministro Joaquim Barbosa, por sua vez, disse que é papel do legislador estabelecer as hipóteses de prestação do serviço de entrega comercial (no qual inclui as cobranças de débitos) pela iniciativa privada, através de contratos de concessão ou permissão.

Também o ministro Gilmar Mendes chamou atenção para a existência de uma margem de flexibilidade do legislador ordinário para tratar do tema. Conforme o ministro, a Constituição, ao prever a competência da União de manter o serviço postal (segundo ele expressão mais abrangente do que explorar diretamente ou mediante autorização, concessão e permissão), possibilita ao legislador escolher o modo através do qual a Administração deve assegurar a prestação do serviço postal à coletividade. Em suas palavras, "Dessa forma, o legislador ordinário poderá, por exemplo, determinar que o serviço postal seja prestado por exploração direta pela Administração Pública; pela exploração indireta, mediante autorização, concessão ou permissão; ou por outros meios, inclusive a execução pela iniciativa privada, nos termos da legislação, mantendo a União o papel de ente regulador, 276 .

O ministro Gilmar Mendes, embora tenha sinalizado que a legislação tem um papel importante para a conformação do setor, no entanto, buscou em seu voto alinhar seus posicionamentos com a realidade do setor, chamando atenção inclusive para a necessidade de avaliar-se uma possível clandestinidade na prestação dos serviços, a depender da interpretação que o próprio STF dá à legislação e à realidade. Trata-se, no entanto, de posicionamento isolado, não representando a posição do Tribunal como um todo.

${ }^{276}$ ADPF n. ${ }^{\circ} 46-7 /$ DF, p. 212-213. 
Em certa medida deixando em segundo plano a reflexão acerca da realidade de prestação dos serviços postais e sinalizando que é dever do Legislativo delinear melhor as regras setoriais, o STF acabou por autorizar as empresas privadas a explorarem as atividades relacionadas a impressos e encomendas livremente, em regime de mercado. Dado que esse entendimento consiste na manutenção do status quo, à interpretação que já vinha sendo dada à legislação postal, recepcionada, parece que a decisão da ADPF n. ${ }^{\circ}$ 467/DF perde muito de sua eficácia prática, revelando-se insuficiente para conferir claros contornos ao setor, garantindo-lhe maior segurança jurídica.

Diante desse cenário, pode-se questionar inclusive a própria questão da persecução penal, em especial a extensão da aplicação do art. 42 da lei $n .^{\circ}$ 6.538/78. Ao final do julgamento, o ministro Ricardo Lewandowski propôs que o Tribunal se manifestasse acerca dessa questão - ponto anteriormente levantado pelo ministro Gilmar Mendes - pois seria fundamental, por exemplo, manifestarem-se sobre se as empresas que entregam encomenda podem ou não ser objeto de persecução penal. Após longa discussão sobre se isso era ou não objeto do pedido, o Tribunal decidiu dar interpretação conforme ao art. 42 conjugadamente com o art. $9^{\circ}$, para que se evitassem situações de pouca clareza e insegurança jurídica. Dado o conteúdo do art. $9^{\circ}$, em termos gerais, essa interpretação do STF restringe a aplicação do art. 42 exclusivamente a cartas, cartões-postais e correspondência agrupada (serviços "monopolizados”).

Segundo o ministro Gilmar Mendes, em seu voto reajustado, a interpretação conforme aos artigos era necessária porque estava enfraquecida a função de garantia do art. 42 (taxatividade), em violação ao princípio da reserva legal estrita (CF, art. 5 , XXXIX; Código Penal, art. $1^{\circ}$ ). De fato, a decisão do STF objetivou tornar o art. 42 menos amplo, uma vez que este, ao tipificar como crime a violação do privilégio postal da União, prevê a coleta, transporte, transmissão ou distribuição, sem observância das condições legais, se referindo de maneira genérica, a “...objetos de qualquer natureza sujeitos ao monopólio da União...”. Implicitamente essa previsão genérica remete ao art. $9^{\circ}$, que lista as atividades postais exploradas em regime de "monopólio". Na medida em que o Tribunal deu interpretação conforme ao art. 42, expressamente restringiu sua aplicação ao art. $9^{\circ}$.

No entanto, não tendo conseguido delimitar quais atividades postais específicas se incluem nesses serviços "monopolizados", pode-se questionar se o Tribunal efetivamente cumpriu o objetivo que pretendia alcançar com a interpretação conforme ao art. 42, conjugado com o art. $9^{\circ}$, qual seja, de precisar quais condutas estão autorizadas, e quais são 
os limites das hipóteses permissivas. Permaneceu ainda a questão de saber em que medida é lícito às empresas privadas prestarem esses serviços autorizados no mercado.

A entendermos que o STF autorizou as empresas privadas a explorarem as atividades relacionadas a impressos e encomendas livremente, em regime de mercado, a Corte, sem ter sinalizado isso expressamente, parece ter retirado dos "serviços postais" (serviço público) as atividades competitivas (impressos e encomendas), o que, no entanto, contradiz seu entendimento de que todos os serviços prestados como postais são serviços públicos. Diante disso, questões como as seguintes claramente permanecem em aberto: em que medida é lícito aos particulares prestarem serviços no mercado postal? Devem ser concessionários e permissionários ou podem seguir atuando numa área que não está reconhecida pela lei ou pela regulamentação? Efetivamente, quais são as atividades que os particulares podem prestar?

Ademais, entender-se que o STF firmou o entendimento segundo o qual a prestação de atividades relacionadas a impressos e encomendas pode ser livremente explorada por particulares, em regime de mercado, deverá trazer reflexos para o regime jurídico aplicável à ECT. Isso porque os privilégios da impenhorabilidade de bens e da imunidade tributária recíproca têm sido conferidos pelo STF à estatal com base no entendimento de que ela presta serviço público. Se impressos e encomendas não têm essa natureza jurídica, sendo livre sua prestação, seguindo a linha de entendimento do STF, esses privilégios não seriam aplicáveis à estatal quando ela transporta impressos e encomendas. Ao mesmo tempo, seria necessário refletir-se sobre mecanismos que possibilitem melhor capacitar a estatal a competir no mercado postal. Restaria então uma dificuldade prática de se modular o regime jurídico da estatal em vista das atividades que presta.

\section{V.3.3.5. Desafio da proliferação de prestadores privados}

Além disso, permanece hoje, em face da recepção do "monopólio" postal de grande parte da rede de atividades, uma dificuldade grande de ordem prática, a ser considerada numa possível reestruturação do setor. Será possível com o uso da força, ou seja, com o uso do poder de polícia, tentar impedir a proliferação da prestação do serviço por empresas privadas? Se sim, como afastá-las no cenário atual? Se não, essas empresas que exercem atividades ilegais não estariam colocando em xeque o poder do Estado brasileiro? 
A operacionalização do papel de fiscalização do setor postal, desempenhado fora do âmbito do Ministério das Comunicações, pela ECT em operações conjuntas com, por exemplo, a polícia federal ${ }^{277}$, também parece ser interessante sob dois aspectos. Primeiro: considerando que todos os serviços postais são serviços públicos, a partir da dicotomia serviços públicos versus atividades econômicas, é necessário que o Estado atue de modo tal que impossibilite a prestação de quaisquer serviços postais por empresas privadas. Caberia então à ECT, em conjunto com o Ministério das Comunicações, celebrar contratos com eventuais concessionárias e permissionárias, precedidos de procedimento licitatório, tal como preconiza o art. 175 da Constituição.

O problema disso é que na prática parece ser extremamente difícil tornar cerca de 15.000 empresas privadas ilegais, empresas essas que foram devidamente autorizadas a funcionar como empresas, regulando-se pelas leis comerciais e civis do país (as empresas funcionam, têm alvará de funcionamento, pagam impostos que são devidamente recolhidos pelo governo, têm CNPJ, geram empregos etc.), o que parece em certa medida contradizer eventual situação de ilegalidade. Além disso, como o mercado postal ainda é promissor do ponto de vista da rentabilidade empresarial e inexistem mecanismos de controle de acesso dos operadores privados, torna-se difícil impedir a proliferação da prestação do serviço por empresas privadas.

Cabe salientar ainda que a ECT atualmente não demonstra ter estrutura suficiente para arcar com todo o mercado postal (o espaço em que ela atua e mais o das empresas privadas), nem parece ter interesse em que essas empresas se tornem clandestinas, em todos os segmentos da rede postal, como se vê da própria manifestação dos seus advogados na ADPF n. ${ }^{\circ}$ 46-7/DF. Ademais, muitas das empresas de distribuição prestam serviços de qualidade, a preços competitivos e impossibilitar a competição pode em última instância gerar grandes prejuízos ao consumidor final, pessoas físicas ou jurídicas. A competição, especialmente quando implantada com regras claras e políticas consistentes, não é necessariamente ruim. Ao possibilitar que os consumidores escolham entre diferentes empresas, ela pode favorecer substancialmente que os preços se reduzam e que as empresas procurem alternativas tecnológicas para o aprimoramento da prestação dos serviços.

${ }^{277}$ Cf. entrevista realizada no Ministério das Comunicações. 
Segundo aspecto: a entendermos que o STF autorizou as empresas privadas a explorarem as atividades relacionadas a impressos e encomendas livremente, em regime de mercado, quaisquer outras atividades que não impressos e encomendas não podem ser prestadas por quaisquer outras empresas que não a ECT. Ocorre que, uma vez que não se sabe exatamente quais são as atividades exercidas como impressos e encomendas, uma vez proferida a decisão no STF na ADPF n. ${ }^{\circ}$ 46-7/DF - a partir da qual é de se esperar um reforço das ações de fiscalização da ECT/Polícia Federal - há dificuldade de se implementar na prática o que deve ser fiscalizado. Como já foi ressaltado, ainda estão em aberto muitos dos questionamentos sobre quais são as atividades lícitas e quais são as atividades ilícitas que devem ser proibidas, especialmente as relacionadas a documentos comerciais (p. ex., boletos de contas de água e luz, entrega de cartões de crédito etc.).

Ademais, como não há mecanismos de controle de acesso (ou mesmo de preços) desses operadores privados (inclusive de grandes multinacionais que têm atuado cada vez mais no Brasil neste âmbito), as ações de fiscalização tendem a ser mais difíceis do ponto de vista operacional. Isso inclusive do ponto de vista de proteção ao cidadão, para evitar-se que as redes do setor sejam usadas para ilícitos, para ações criminosas, de terrorismo, tráfico etc.

Há ainda outra questão a ser considerada, de saber se as ações fiscalizadoras também devem envolver as agências franqueadas e permissionárias existentes. É dizer, na medida em que é lícito às agências franqueadas e permissionárias receberem carta, por exemplo, não estariam afrontando o "monopólio" postal, de acordo com o art. 9, I, lei n. ${ }^{\circ}$ 6.538/78? O "monopólio" objetiva preservar a bandeira ECT, a marca, ou as receitas necessárias à consecução das atividades da estatal ou a melhor prestação dos serviços pela estatal? A depender de reflexões em torno de questões como essas, não há como manterem-se as franqueadas e permissionárias prestando as atividades "monopolizadas".

Nesta linha, inclusive, como já mencionado, a nova lei de franquia e decreto que a ela se relaciona, aplicáveis ao novo modelo de agências, não incidentes sobre as franquias que estavam operando, expressamente vedam que as atividades de recebimento, expedição, transporte e entrega de objetos de correspondência, valores e encomendas, inerentes à prestação dos serviços postais, sejam objeto de contrato de franquia (art. $2^{\circ}, \S 2^{\circ}$ do decreto), previsão que como já visto teve como um dos seus objetivos evitar que o "monopólio" detido pela ECT fosse vulnerado (item V.2.3.4). 


\section{V.3.3.6. Necessidade de avaliação da função do "monopólio" postal}

Subjacente a essa questão da possibilidade prática de se assegurar o "monopólio" postal, permanece outra, de saber se vale a pena tentar afastar a prestação privada das atividades postais. Embora na decisão do STF tenha ficado num plano bastante secundário a reflexão sobre a razão de se estar garantindo à ECT a prestação exclusiva de algumas atividades postais, a função do "monopólio" postal, algumas questões voltadas a este aspecto se colocam especialmente importantes porque a decisão do STF na ADPF n. ${ }^{\circ}$ 46-7 não vincula uma possível reestruturação do setor, razão pela qual uma lei que trate de um novo marco regulatório para o setor postal pode ser editada sem que preveja um regime de exclusividade à ECT, assim como o próprio entendimento do STF pode se alterar.

Em outros termos, tem-se ainda hoje espaço para a reflexão sobre questões como as seguintes: a competição é em si ruim para o setor ou ela pode ser usada de modo tal que beneficie o aprimoramento dos serviços postais? Será que, por exemplo, empresas concessionárias de serviços públicos (de água, luz, telefone etc.) não podem buscar soluções de entrega de contas mais eficientes e mais baratas que beneficiem os usuários porque os Correios entendem que têm o "monopólio" dos serviços de entrega de contas? Até que ponto esse "monopólio" não constitui um ônus indevido para a sociedade? Até que ponto o "monopólio" é juridicamente legítimo e economicamente necessário?

A questão da entrega de contas, que continua gerando discussões, por exemplo, traz em si a questão de saber em que medida as ações conservadoras no sentido de impedir que SABESP, ENERGISA, SAAE, por exemplo, entreguem suas contas aos seus consumidores, independentemente dos Correios, acabam constituindo-se em obstáculo ao progresso, ao desenvolvimento do próprio processo tecnológico, que vem se alterando ao longo do tempo. Em que medida é legítimo que a empresa ECT, ao buscar recursos para seu desenvolvimento, impeça que o processo tradicional seja substituído por um processo mais célere e funcionalmente mais eficiente (sujeito a menos erros, mais barato, simplificado, conveniente etc.)? ${ }^{278}$

\footnotetext{
${ }^{278}$ É possível ainda argumentar que no caso de concessionárias que entregam contas (como no caso da Sabesp, em que no sistema de leitura de hidrômetro o técnico mede o consumo de água no local e ao mesmo tempo emite o boleto de cobrança ao cliente), como elas estariam prestando serviços para si (o interessado diretamente mantém o sistema, por seus próprios meios) e não para venda no mercado, sua atividade não seria "monopolizada", pois o art. $9^{\circ}, \S 2^{\circ}$, a, da lei n. ${ }^{\circ} 6.538 / 78$ expressamente afirma que "Não se incluem no regime de monopólio: a) transporte de carta ou cartão-postal, efetuado entre dependências da mesma pessoa jurídica, em negócios de sua economia, por meios próprios, sem intermediação comercial". No
} 
Uma interpretação ampla e conservadora do "monopólio" postal pode não apenas impossibilitar essas soluções de entregas de contas, como ainda outras que estão surgindo ou podem vir a se desenvolver. Na medida em que a tendência atual é a substituição dos papéis por novas formas eletrônicas, tem sido desenvolvido pela Federação Brasileira de Bancos (Febraban), em conjunto com os bancos associados, um sistema denominado Débito Direto Autorizado $\left(\mathrm{DDA}^{279}\right)$. Atualmente já é possível que as compensações financeiras de boletos sejam realizadas de forma eletrônica, sem o trânsito do documento físico.

Com a implementação do novo sistema, já em operação, os clientes dos bancos podem optar no sentido de que todos os seus compromissos de pagamentos sejam recebidos eletronicamente, por meio dos bancos, sendo os valores das transações automaticamente creditados nas contas. Com isso, os clientes não precisam mais receber os boletos de pagamentos em papel, bastando autorizar os pagamentos no banco que escolherem. Em certa medida, conforme entrevista realizada no Ministério das Comunicações, essa modernização dos pagamentos tende a acarretar a evaporação do tráfego postal (a transação é toda eletrônica), será que isso também constitui afronta ao "monopólio" postal?

Essa evolução tecnológica de fato nos coloca diante da necessidade de avaliar, sob um ponto de vista mais funcional e aplicado, a necessidade de manter-se o "monopólio" postal e sobre quais áreas ele tem de ser mantido. Se de um lado parece legítima a preocupação com a manutenção da ECT (em grande medida as decisões do STF demonstram que o Tribunal tem uma clara preocupação com a preservação da estatal), também parece legítimo conferir-se aos consumidores a possibilidade de se utilizarem de soluções criadas ao longo do desenvolvimento do processo tecnológico. Ademais, na medida em que a legislação postal e a interpretação que a ela deram os ministros do STF propagam um estado de incertezas, as próprias empresas podem não mais ter interesse em desenvolver soluções de mercado inovadoras e em investir recursos numa atividade na qual não sabem ao certo por quanto tempo poderão atuar. Neste sentido, esse estado de incertezas que vem sendo propagado no mercado postal prejudica o setor postal como um todo e pode criar entraves ao próprio desenvolvimento do país.

entanto, nesses casos pode ocorrer de os serviços serem terceirizados, ainda que sejam feitos em nome da concessionária.

$279 \quad$ Disponível em: <http://www.febraban.org.br/projetodda/dda_historico.asp > e $<$ http://www.febraban.org.br/projetodda/dda_oque.asp>. Acesso: 12.08.2011. 


\section{V.4. Heterogeneidade do conteúdo dos serviços postais em face do regime jurídico: possíveis núcleos materiais de serviços públicos no setor postal e o cenário proposto pelo PL n. ${ }^{\circ}$ 1.491/97}

Diante desse quadro do setor postal, diagnosticados entraves e perplexidades jurídicas do ponto de vista legislativo, doutrinário e jurisprudencial, verifica-se que a aplicação do regime jurídico da ECT merece um enfoque distinto da unificação de regime baseada na dicotomia empresa estatal prestadora de serviço público versus empresa estatal exploradora de atividade econômica a que se tem assistido.

Parece agregar mais ao debate sobre o setor dar menor ênfase a interpretações constitucionais do que é serviço público, ao menos do modo como essas interpretações vêm sendo feitas (o que pode ser a "armadilha", da qual decorrem as outras), voltando-se em maior medida para uma interpretação mais aplicada e funcional e mesmo para o desenvolvimento de novas ferramentas para o setor, que forneçam condições para que novas soluções sejam adotadas para resolver os problemas setoriais.

Partindo da ideia segundo a qual o direito deve ser visto cada vez mais como um instrumento de consecução de fins ${ }^{280}$, exercendo um papel essencial para a implementação e estruturação de políticas públicas, seja no nível legislativo, executivo ou judicial, e de que o direito é um veículo importante para o desenvolvimento de um país, seja sob a ótica da implementação de decisões já tomadas, seja mesmo sob a ótica da modelagem de decisões governamentais ${ }^{281}$, tem-se um claro espaço para a criatividade institucional: formulações doutrinárias e jurisprudenciais, institutos e instituições devem ser repensados, recriados ou mesmo concebidos.

\footnotetext{
${ }^{280}$ No Estado pós-liberal, como nos diz Fábio Konder Comparato, “(...) a função primordial do Estado (...) passou a ser a produção de políticas ou programas de ação. No primeiro caso [no modelo de Estado liberal], o Direito apresentava um caráter meramente declaratório da 'ordem natural das coisas'; no segundo [com o advento do Estado pós-liberal], ele se torna um instrumento de consecução de fins, ou seja, assume o caráter de norma técnica." ("Ordem econômica na Constituição brasileira de 1988”, Revista de Direito Público, n. ${ }^{\circ}$ 93, p. 264). Mais adiante, o autor ainda afirma: "A função social da ordem jurídica não é, evidentemente, a de suprir a ausência de políticas públicas e, sim, a de criar as condições institucionais para que elas se desenvolvam eficazmente." ("Ordem econômica na Constituição brasileira de 1988", Revista de Direito Público, n. ${ }^{\circ}$ 93, p. 275).

281 "Da mesma forma como ocorre com a decisão sobre a destinação dos recursos públicos (...) no âmbito da elaboração das leis orçamentárias, as diversas afetações atribuídas aos bens públicos constituem decisões de implementação de políticas públicas." (Floriano de Azevedo Marques Neto, O regime jurídico das utilidades públicas: função social e exploração econômica dos bens públicos, p. 521). Alguns autores chegam mesmo a dizer que vivemos hoje no que denominam de "novo Estado desenvolvimentista", o que resulta em repensar o papel do Direito para o desenvolvimento. Ver, por todos, David Trubek, Law and development in a time of multiple visions: the challenge of law in the new developmental state.
} 
Neste sentido, tendo em vista os "gargalos" setoriais, é essencial que se estabeleçam regras e políticas setoriais claras e consistentes, que prevejam as pautas e metas para a organização da exploração dos serviços postais no Brasil. Retomando a classificação proposta por Norberto Bobbio, apresentada na proposta metodológica desta dissertação (item II), parece ser essencial que o direito aplicável ao setor postal caminhe de um ângulo substancialmente estrutural para um ângulo essencialmente funcional. Uma vez detectados problemas no setor, deve-se caminhar para a análise de soluções práticas orientadas a partir das finalidades que se pretende atingir no setor, de modo que elas sejam implementadas num futuro próximo.

Para resolver os problemas que hoje comprometem o setor postal brasileiro não basta apenas ter foco na ECT. Paralelamente ao projeto que já vem sendo implantado, de se resolver os problemas de gestão da estatal, de modo que ela, passando a ser mais organizada, eficiente e modernizada, aprimore sua capacidade de atuar no setor, deve-se criar um espaço para o desenvolvimento de políticas públicas para o setor postal como um todo. Isso porque as políticas voltadas à ECT, a despeito de terem seu mérito, não têm o condão de assumir o espaço existente para as políticas públicas do setor postal como um todo. Menos do que serem vistas como excludentes, devem se complementar, conectandose a partir de um objetivo comum, tendo em vista o aprimoramento da prestação dos serviços postais no Brasil.

Além de estar em curso um projeto de revitalização da ECT, num passado recente iniciado em 1997 com o programa Reforma Estrutural do Setor Postal Brasileiro (através da portaria n. ${ }^{\circ} 778$ do Ministério das Comunicações) foi discutida de maneira mais ampla uma possível reestruturação do setor postal. Como anteriormente mencionado, como fruto do programa de reforma foi encaminhado ao Congresso Nacional em 1999 o projeto de lei n. ${ }^{\circ}$ 1.491, acompanhado da Exposição de Motivos EMI n. ${ }^{\circ}$ 89/MC/MF/MOG. O projeto do que poderia vir a ser a Lei Geral do Sistema Nacional de Correios (que "dispõe sobre a organização do Sistema Nacional de Correios, do seu órgão regulador, e dá outras providências") foi retirado em outubro de 2003 , através da mensagem n. ${ }^{\circ} 558^{282}$.

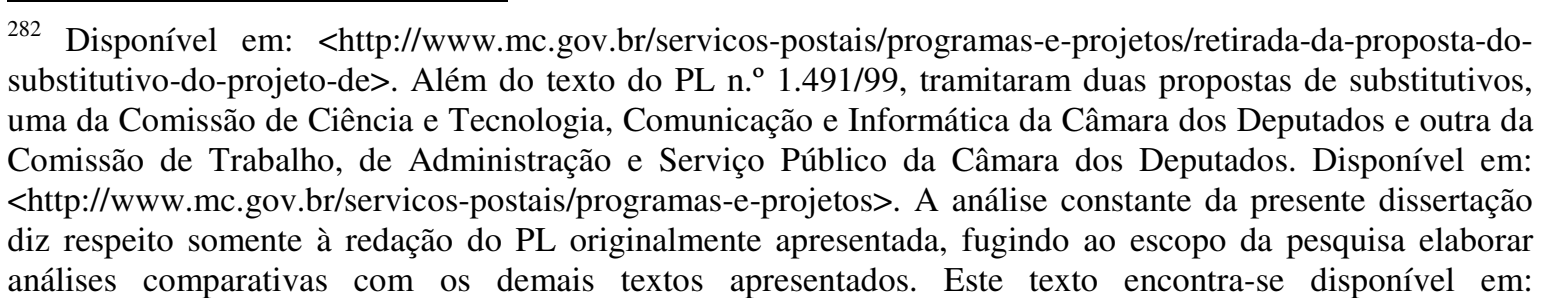


Embora tenha sido paralisada sua tramitação, dada a repercussão que o projeto teve na época, a inexistência de outros projetos tão bem estruturados e a possibilidade de a discussão mais ampla sobre perspectivas de reestruturação do setor ser retomada, inclusive tendo em vista essa proposta do PL n. ${ }^{\circ}$ 1.491/99, que veiculou um modelo regulatório diferente do aplicável atualmente, é importante assinalar seus principais contornos, pois suas regras podem servir de referencial ou contraponto ao desenho regulatório que pode vir a ser implantado numa futura reforma do setor. Foge ao escopo da presente dissertação analisar com profundidade o projeto em todo o seu teor, sendo, no entanto, oportuno assinalar suas principais linhas condutoras, que em grande medida relacionam-se à incidência de regimes jurídicos distintos, em vista da heterogeneidade do conteúdo dos serviços postais, o que nos levará a um diálogo importante com as ideias desenvolvidas no Capítulo 2.

Subjacente ao projeto claramente está a adoção de uma concepção ampla de serviço público, respaldada no entendimento segundo o qual serviço público engloba “...atividades relevantes e de interesse público, independentemente do regime por meio do qual ele é prestado",283 (analisado no item V.1.1), possibilitando que a previsão constitucional que confere à União competência para manter o serviço postal (art. 21, X) permita a acomodação de prestadores em regime público e em regime privado. "Manter" o serviço postal equivaleria a de um lado garantir a prestação dos serviços essenciais (sujeitos a metas de qualidade e universalização) e de outro organizar o Sistema Nacional de Correios $(\mathrm{SNC})^{284}$, inclusive em relação aos serviços prestados em regime privado (art. $2^{\circ}$, caput).

A este SNC, organizado por intermédio de órgão regulador e nos termos das políticas estabelecidas em lei, caberia dizer se existem ou não serviços essenciais à população (art. $2^{\circ}, \S 1^{\circ}$ ), competindo ao Poder Executivo, por meio de decreto, definir a amplitude dos serviços essenciais, bem como sua prestação em regime público ou privado (art. $3^{\circ}, \mathrm{I}$ ), aprovar as metas de qualidade e universalização desses serviços (inciso II), e aprovar plano de exploração dos serviços essenciais (inciso III). De outro lado, caberia ao SNC regulamentar, disciplinar, planejar e fiscalizar o uso e a exploração econômica de

<http://www.mc.gov.br/images/servicos-postais/programas-e-projetos/projeto-lei--n1491-1999.pdf> e a exposição de motivos a ele relacionada em: <http://www.mc.gov.br/images/servicos-postais/programas-eprojetos/exposicao-motivos-interministerial-n89-1999.pdf>. Acesso (a todos os materiais referidos nesta nota): 27.09.2011.

${ }^{283}$ Vera Monteiro, Concessão, p. 86.

${ }^{284}$ O PL define o SNC da seguinte forma: “Art. $9^{\circ}$. - O Sistema Nacional de Correios é o conjunto integrado pelos operadores, órgão regulador, redes físicas e processos que, de forma articulada e inter-relacionada, concorrem para a prestação à sociedade dos serviços de correios, observados os parâmetros desta Lei." 
todas as modalidades de serviços de correios e atividades inerentes aos serviços postais no Brasil (art. $\left.2^{\circ}, \S 2^{\circ}\right)$.

Os serviços essenciais seriam prestados no mínimo por um operador em regime público, podendo ser prestados também em regime privado por outros operadores (art. $4^{\circ}$, $\S 1^{\circ}$ ), e os serviços não-essenciais seriam prestados tão somente no regime privado ( $\operatorname{art} .4^{\circ}$, $\S 2^{\circ}$ ). Em grande medida, assim, a incidência do regime público ou privado variaria conforme sejam as atividades essenciais ou não-essenciais. Embora o projeto remeta a definição da essencialidade dos serviços ao SNC articulado com o Poder Executivo segundo o art. 20, competiria ao Poder Executivo, mediante proposta encaminhada pela Agência, definir as modalidades de serviços de correios que integram o serviço essencial -, dá alguns contornos para a sua caracterização, conteúdo e financiamento.

A caracterização do serviço como essencial visa fundamentalmente à consecução de dois objetivos: garantir que os serviços importantes ao cidadão sejam a ele acessíveis, e que seja assegurada a prestação de serviços importantes para o desenvolvimento e integração nacional. Dada sua essencialidade para a coletividade, em paralelo a uma prestação privada, “...a União obriga-se a assegurar a toda a sociedade, em todo o território nacional, de modo contínuo e economicamente acessível e com observância das metas e deveres de qualidade e universalização..." (art. 19).

Uma vez estabelecidos critérios para a diferenciação do serviço postal por conta de sua essencialidade (o PL já estabelece alguns serviços que por suas características são considerados essenciais ${ }^{285}$ ), possibilita-se a aplicação diferenciada de regimes jurídicos, que também se lastreia no reconhecimento de que o serviço postal engloba um leque vasto de serviços e na delimitação de quais atividades são englobadas nos "serviços de correios", constituídos pelo serviço postal, serviço parapostal e serviço de interesse social (art. 10; a definição de cada qual consta dos artigos 11 a $13^{286}$ ), e ainda por outras modalidades de

\footnotetext{
${ }^{285}$ Pelo artigo 21, sem prejuízo de outros, são considerados essenciais os seguintes serviços: (i) "o serviço de telegrama" (inciso I); (ii) "o envio, no âmbito nacional e a expedição para o exterior, de correspondência ou objeto postal que tenha peso máximo de dois quilogramas, observados os padrões de freqüência, prazo de entrega e dimensões fixados pelo Poder Executivo, mediante proposta da Agência" (inciso II); e (iii) "a transferência, a remessa ou o recebimento de dinheiro ou valores até o limite de mil vezes o valor da tarifa básica unitária do serviço de carta" (inciso III).

${ }^{286}$ De maneira geral, sem as minúcias encontradas nos incisos e parágrafos dos referidos artigos, os "serviços de correios" são definidos da seguinte forma: "Art. 11. Serviço postal é o conjunto de atividades que torna possível o envio de correspondência ou objeto postal de um remetente para um endereço final certo e determinado, com ou sem indicação de destinatário, sob o regime de prestação definido nesta Lei”; "Art. 12. Serviço parapostal é o serviço correlato, conexo ou afim ao serviço postal"; "Art. 13. Serviço de interesse social é aquele relevante para a coletividade e para o Estado prestado aos usuários pelo operador, cuja
} 
serviços definidos pelo órgão regulador, em razão de atributos como natureza, forma, âmbito, modo de postagem, tecnologia empregada, prazo e local de entrega (art. 14).

Claramente, assim, o PL adota uma diferenciação da rede postal e, pois, da regulação que sobre ela incide, em vista dos serviços que ela comporta, deixando de lado a possibilidade de diferenciar-se a intensidade da regulação em vista das sub-redes existentes na cadeia do setor postal (de recebimento, expedição, transporte e entrega de objetos postais), conforme visto no item IV.3 do Capítulo 2.

Adotada essa divisão por serviços, para a aplicação diferenciada de regimes jurídicos, o PL prevê, por exemplo, a prestação dos serviços por no mínimo um operador em regime público, operando os serviços concomitantemente com outros prestadores privados. A esse respeito, vale ressaltar também a previsão de fontes de financiamento diferenciadas para suportar os custos do serviço essencial prestado em regime público (art. $22^{287}$ ), dentre as quais estão a transferência de lucros decorrentes da exploração pelo operador em regime público de outros serviços e atividades, o pagamento pelos demais operadores (regime privado) de valor adicional ao preço decorrente da utilização da rede física do operador em regime público, e a criação de fundo de universalização dos serviços essenciais. Mencionem-se ainda os deveres, de universalização e continuidade, inerentes ao regime público, incidente sobre os serviços essenciais (art. 44 a 47), bem como prerrogativas próprias ao operador em regime público (art. 48).

execução dependa ou seja consideravelmente facilitada pela utilização de sua rede física, sem prejuízo da prestação dos demais serviços de correios".

287 “Art. 22. Os custos do serviço essencial prestado em regime público, que não puderem ser cobertos com a sua regular exploração, poderão ser financiados pelas seguintes fontes: I - transferência dos lucros decorrentes da exploração, pelo operador em regime público, de outros serviços e atividades, inclusive dos lucros auferidos por subsidiárias, coligadas ou controladas; II - pagamento, pelos demais operadores, de valor adicional ao preço decorrente da utilização da rede física do operador em regime público; III - fundo destinado a garantir a universalização dos serviços essenciais, que vier a ser criado especificamente para esta finalidade; IV - orçamento geral da União; V - recursos, mediante convênio ou forma equivalente, dos Estados, do Distrito Federal e dos Municípios; ou VI - doações efetuadas por pessoas físicas ou jurídicas. Parágrafo único. O sistema de compensação para o financiamento do serviço essencial a que se refere esse artigo será disciplinado pela Agência." 
Cada uma das modalidades de serviços de correios seria regulada pela Agência (Agência Nacional de Serviços de Correios), à qual caberia estabelecer deveres, direitos e condicionamentos dos operadores e dos usuários (art. 23). A partir disso, permite-se que, considerada a heterogeneidade do conteúdo dos serviços postais, definam-se verdadeiros núcleos materiais de "serviços públicos" em sentido amplo, nos quais incidiriam diferentes graus de regulação. A adoção de um modelo semelhante a esse permite, por assim dizer, que, consideradas as especificidades dos diferentes serviços, eles sejam submetidos a diferentes incidências regulatórias, em vista de seus mais variados aspectos, deixando de lado a aplicação de um único regime jurídico geral, aplicável às mais diversas atividades integrantes da rede postal.

Neste sentido, o PL estabelece, por exemplo, que os serviços não-essenciais estariam sujeitos “...apenas aos condicionamentos necessários para que sua exploração não prejudique o interesse público e os direitos dos usuários" (art. 25, I), e que a regulação, normatização, disciplinamento, controle e fiscalização incidiriam sobre todos os serviços do SNC, devendo essa incidência ser proporcional à importância dos serviços para a coletividade (art. 25, II).

Retomando as ideias desenvolvidas especialmente ao longo do Capítulo 2, item IV.4, a rede postal seria essencialmente diferenciada pelos serviços dela integrantes, tendo por base os graus de essencialidade dos serviços, seu conteúdo econômico e a possibilidade de, de maneira geral, o setor postal funcionar em condições concorrenciais, podendo organizar-se em regime competitivo ou semicompetitivo.

Subjaz ao PL ainda o objetivo de abranger todos os prestadores do setor postal na atividade regulatória estatal, submetendo-os, todos, a regras comuns e a direitos, deveres, e condicionantes específicos, tendo em vista as diferentes intensidades regulatórias a que se sujeitam. De maneira geral, são previstos comportamentos a serem coibidos, por comprometerem a existência do serviço essencial ou que sejam prejudiciais à livre, ampla e justa competição entre operadores (art. 24), bem assim obrigações comuns a todos os operadores (art. 27), como a de submeter-se à fiscalização da Agência, ter disponíveis relatórios periódicos de sua situação financeira e dos indicadores de qualidade e eficiência, informar a localização de sua sede e de suas instalações e os nomes dos seus dirigentes, observar e zelar pela manutenção do sigilo da correspondência, bem como pela confiabilidade e integridade do objeto postal, zelar para que as redes físicas não sejam utilizadas para fins ilícitos, cumprir fielmente os termos constantes dos instrumentos de 
concessão, permissão ou autorização, em especial a área de abrangência do serviço concedido, permitido ou autorizado, dentre outras.

Ao submeter todos os prestadores de serviços postais a obrigações comuns como essas e a regras específicas constantes dos instrumentos de concessão, permissão e autorização, sendo que todos os prestadores devem ser necessariamente concessionários, permissionários ou autorizatários (apenas serviços de interesse restrito definidos pela Agência não dependeriam de autorização, conforme art. 90, §2 $2^{\circ}$, impede-se que se replique o modelo atual, no qual boa parte dos prestadores do setor, especificamente as empresas de courier (cerca da 15.000 empresas privadas que atuam no setor), passaram a atuar no setor sem se submeterem a quaisquer mecanismos de controle de acesso desses operadores, regulando-se tão somente pelas leis comerciais e civis do país, sem se sujeitarem a condicionantes próprias ao setor postal (relacionadas, por exemplo, a regras de segurança), previstas na legislação (no PL, que futuramente seria convertido em lei), num instrumento de outorga e mesmo junto à Agência, que representa um vínculo de todos os prestadores e, pois, uma forma de se controlar sua atuação no mercado. Permite-se ainda que se limite o número de operadores por regiões do país, como preveem o art. 50, em relação à outorga de concessões dos serviços de correios, e os artigos $88, \S^{\circ}$ e 92 , em relação às autorizações.

Um modelo como este do PL possibilita, pois, que todos os operadores do setor submetam-se a uma regulação mais incisiva - ao menos no plano legislativo -, ainda que moldada em vista das características dos serviços prestados pelos operadores do setor (pressuposto da diferenciação da aplicação de regimes jurídicos, público ou privado).

Nesta linha, o PL prescreve a exploração de serviços de correios em regime público através de concessão (art. 49), outorgada mediante processo licitatório (art. 51), admitida a possibilidade de a Agência restringir a acumulação de concessões para exploração de mais de uma modalidade de serviços de correios ou em mais de uma região pela mesma concessionária (art. 53). Nos termos do PL, “...o Poder Executivo poderá estabelecer, por meio de decreto, as regiões em que se dividirá o País para fins de concessões dos serviços de correios, o número de operadores em cada região, a existência ou não de um operador em âmbito nacional e o prazo para admissão de novos operadores em regime público" (art. 50). 
Por serem os serviços essenciais e, pois, o regime público, não apenas os prestadores submetem-se aos deveres de universalização e continuidade, como também a maiores sujeições, determinadas no contrato de concessão (art. 56), relacionadas, por exemplo, ao âmbito territorial de prestação do serviço concedido, às regras e condições de execução do serviço, aos critérios, parâmetros e indicadores de qualidade, expansão e modernização do serviço, às tarifas a serem cobradas dos usuários, aos direitos e obrigações dos usuários, à Agência e concessionária, às possíveis receitas e fontes de financiamento, aos bens reversíveis, se houver, às condições de compartilhamento das redes físicas, dentre outras.

O regime público admite ainda a exploração por permissionários, mas em caráter excepcional e transitório, nas hipóteses de haver “...risco de comprometimento do funcionamento do serviço essencial e não for possível ou viável a outorga de concessão, a intervenção na concessionária, nem a prestação direta do serviço" (art. 80). Tal como a concessão, a permissão deve ser precedida de procedimento licitatório, devendo o instrumento contratual especificar direitos e obrigações do permissionário, usuários e Agência, e os parâmetros gerais para exploração do serviço permitido, inclusive quanto à sua continuidade e universalidade (art. 82; as especificações do contrato de permissão são menos especificadas no PL, em comparação com o de concessão).

De outro lado, o PL prevê a exploração de serviços postais em regime privado, mediante autorização. Para fins de aplicação do artigo, os serviços postais prestados em regime privado são “...todos os serviços de correios, inclusive as modalidades que, compreendidas no serviço essencial, não sejam prestadas com deveres de universalização e de continuidade" (art. 86). Ainda que submetidos ao regime privado, esses serviços e seus operadores (autorizatários) deveriam se submeter à atividade regulatória da Agência, bem como a condicionamentos administrativos, necessários para garantir competição, diversidade de serviços e operadores, respeito aos direitos dos usuários e equilíbrio entre estes e os operadores, isonomia de tratamento entre os prestadores, fiscalização, a existência, continuidade e eficiência do serviço essencial, dentre outros (art. 87).

Regra geral, a autorização para exploração dos serviços em regime privado, que incumbe à Agência, deveria ser dada a todos os operadores que preencham as condições subjetivas e objetivas necessárias (art. 90), podendo a Agência negar a concessão de autorização em algumas hipóteses específicas, como em situações excepcionais (art. 88, incisos I a III), e ainda oferecer restrições ao número de autorizações para exploração de 
um serviço em uma dada região quando a preservação do serviço ou as condições de competição assim determinarem (art. $88, \S 1^{\circ}$ ). O estabelecimento das condições objetivas e subjetivas para a obtenção de autorização ficaria a cargo da Agência, sendo algumas condições subjetivas já elencadas no art. 91, que veda à interessada, por exemplo, ser proibida de licitar ou contratar com o poder público, explorar a mesma modalidade de serviço, na mesma região, em regime público, e explorar outras modalidades de serviços, em regime público ou privado, quando tal acumulação for vedada pela Agência.

O país seria dividido em áreas ou regiões de abrangência de cada categoria de autorização (que poderiam ou não coincidir com as áreas de abrangência de outorga de concessão para exploração dos serviços no regime público), repartidas por modalidades de serviços de correios, havendo a possibilidade de um operador atuar em mais de uma delas (art. 92), devendo, se limitado o número de prestadores, a seleção ser precedida de procedimento licitatório $\left(\operatorname{art} .88, \S 2^{\circ}\right)$.

Mencione-se ainda que, diferentemente dos serviços prestados em regime público, remunerados mediante pagamento de tarifas por parte dos usuários, as quais devem ser fixadas pela Agência (art. 65), o operador em regime privado seria livre para fixar os preços cobrados do usuário (art. 89).

Diante disso, é possível afirmar que o PL estrutura-se fundamentalmente na criação de regimes jurídicos distintos tendo em vista o conteúdo heterogêneo dos serviços postais. Lida, assim, com a expansão das atividades postais e com o aumento de prestadores no setor. Deixando de lado a concepção segundo a qual existe um regime jurídico único e geral para os serviços públicos e para as atividades econômicas, em grande medida o PL confere a determinação das sujeições a que o particular terá de se submeter ao arranjo contratual moldado para o caso concreto, conforme as peculiaridades do serviço prestado, o que tiver sido definido no ato de outorga (concessão e permissão) e a legislação aplicável.

Mesmo as atividades livres aos particulares (exploradas em regime privado), ainda que sujeitas à dinâmica do livre mercado, por suas características, teriam de se submeter à autorização, como ato de polícia administrativa num setor regulado da economia. Neste sentido, por exemplo, as obrigações veiculadas de submissão à fiscalização da Agência e de ter disponíveis relatórios periódicos da situação financeira e de indicadores de qualidade. Mesmo nesse caso de prestação privada, o PL não impede que o poder público induza comportamentos, com vistas a atingir finalidades públicas. Neste sentido, por 
exemplo, denota uma preocupação com a acomodação de prestadores públicos e privados pelas diferentes regiões do país.

Esse modelo regulatório, da forma como estruturado, respalda-se em grande medida na criação de uma Agência (disciplinada pelos artigos 121 e seguintes do PL), à qual competiria regular todas as modalidades de serviços de correios e, pois, todos os operadores, em vista das atividades que prestam e, consequentemente, dos distintos regimes jurídicos a que se submetem. De certa forma, a criação de um órgão regulador independente traz consigo o objetivo de mitigar a hoje existente "confusão" entre políticas do setor postal e a ECT (inexistente uma clara divisão de papéis de planejamento, execução, normatização, fiscalização e regulação no setor), que pode estar gerando problemas de governança à estatal e em relação à transparência com que ela se apresenta à sociedade civil (Capítulo 1, item III.2.1) ${ }^{288}$. A regulação já não se daria a partir da ECT, mas sim dos objetivos que se busca atingir no setor, tendo a ECT como um dos operadores postais, e reconhecendo que o serviço postal pode ser prestado por outros operadores, todos regulados, mas submetidos a distintas intensidades regulatórias.

No que tange especificamente à atuação da estatal no setor, o PL prevê regras para sua reestruturação, relacionadas à sua transformação em sociedade de economia mista vinculada ao Ministério das Comunicações, com denominação alterada para "Correios do Brasil S.A. - Correios" (art. 175) e à possibilidade de seu objeto social ser ampliado para abarcar novas modalidades de serviços, inclusive financeiros, em regime privado, e de transporte, inclusive de valores (art. 175, parágrafo único). O PL autoriza ainda que o Poder Executivo adote medidas de reestruturação e reorganização da ECT (art. 176), como a cisão em várias empresas com objeto social segmentado por atividades ou modalidades de serviços; a segmentação do objeto social da empresa, com a constituição de subsidiárias, coligadas ou controladas, inclusive com sede no exterior; a abertura do capital da empresa; a associação da empresa com outras atuantes no âmbito do SNC, dentre

\footnotetext{
${ }^{288}$ Nesse sentido, ao tratar das agências reguladoras independentes, Floriano de Azevedo Marques Neto afirma que a atividade estatal de regulação tem como pressupostos “(...) i) a separação entre o operador estatal e o ente encarregado da regulação do respectivo setor e ii) a admissão pelo setor regulado da existência de operadores privados competindo com o operador público (introdução do conceito de competição em setores sujeitos à intervenção estatal direta), o que leva alguns autores a caracterizar essa nova regulação como 'regulação para a competição"” (Agências reguladoras independentes: fundamentos e seu regime jurídico, p. 30-31). Sobre a independência como pressuposto de constituição das agências reguladoras, ver p. 67-80.
} 
outras. Prescreve ainda outras regras aplicáveis ao processo de reestruturação e reorganização (arts. 177 a 181).

Este desenho regulatório também estabelece um regime competitivo ao setor postal de maneira geral, possibilitando que todos os segmentos da cadeia produtiva do setor, inclusive os serviços que atualmente são prestados em regime de exclusividade, sejam abertos ao funcionamento concorrencial, cabendo apenas definir a extensão de serviços prestados por cada um dos prestadores (concessionários, permissionários e autorizatários). Detectada a possibilidade de funcionamento do setor postal em condições concorrenciais, o PL estabelece a organização de uma transição da regulação para o regime competitivo, prescrevendo regras para um regime não exclusivo, definindo em determinados períodos de tempo quais segmentos dentro da cadeia produtiva teriam possibilidade de viver em concorrência e em que extensão.

Neste sentido, o PL estabelece que a exclusividade nos serviços de "atendimento, coleta, triagem, transporte e distribuição no território nacional, e a expedição para o exterior, de carta e cartão-postal"; "o serviço público de telegrama"; e "o atendimento, coleta, triagem, transporte e distribuição no território nacional, e a expedição para o exterior, de correspondência agrupada" (art. 184, incisos I a III) seria extinta ao final do prazo de dez anos (art. 184, $\S 1^{\circ}$ ). A abrangência dos serviços exclusivos, segundo veicula o art. $184, \S 2^{\circ}$, poderia ser reduzida para o prazo de cinco anos pelo Poder Executivo, por proposta da Agência.

De todo modo, a exclusividade não se aplicaria às atividades e serviços realizados pelas agências de atendimento da ECT, que fossem objeto de concessão, permissão ou autorização específica, nos termos da regulamentação que seria editada pela Agência (art. 184, $\S 3^{\circ}$ ). A figura das Agências de Correio Franqueadas (ACF’s), em vista desta previsão e da previsão segundo a qual os contratos celebrados entre ECT e ACF's permaneceriam válidos pelos prazos nele previstos (art. 185), denota a intenção do PL de substituir as atuais franquias postais por concessionárias, permissionárias e autorizatárias reguladas pela Agência.

Admitida, assim, a possibilidade de a ECT, como mais um operador postal, prestar serviços em regime público e em regime privado, a depender da relevância do serviço envolvido com vistas a atingir finalidades públicas, não mais seria devida a aplicação uniforme de um regime jurídico protetivo à estatal, consubstanciado especialmente nos privilégios da impenhorabilidade de seus bens e da imunidade tributária recíproca. Nesse 
caso, subjacente ao PL parece estar a visão segundo a qual também o regime jurídico da ECT passaria a ser modulado, conforme variarem as atividades desenvolvidas pela empresa (tendo em vista sua essencialidade para a coletividade e seu conteúdo econômico), e de acordo com a necessidade de o Estado regulá-las.

Esta questão da aplicação dos privilégios da impenhorabilidade de bens e da imunidade tributária não foi expressamente enfrentada pelo PL. No entanto, parece estar subjacente ao projeto o reconhecimento de que esses privilégios são aplicáveis a determinadas entidades com a função de resguardar bens e serviços públicos, função que foi analisada neste capítulo, especialmente no item V.2.3.2. O desenho regulatório proposto pelo PL coaduna-se menos com um enquadramento genérico dos bens da ECT como públicos, voltando-se mais para a aplicação da impenhorabilidade aos bens essenciais e indispensáveis para o desempenho de funções públicas. Do mesmo modo, parece estar subjacente ao modelo o entendimento segundo o qual o alcance da imunidade tributária ficaria restrito às pessoas políticas e entes que lhe são equiparados somente quando desempenham suas funções típicas.

Em grande medida, isso possibilita que sejam aplicados mecanismos existentes ou mesmo que sejam criados outros, que permitam à estatal competir em igualdade com as demais prestadoras privadas, sendo-lhe reservado regime específico e mais protetivo na medida do necessário pelos serviços de caráter público que presta à coletividade, atividades entendidas aqui como as prestadas em regime público ou mesmo em privado, desde que isso se justifique no caso concreto.

Com a aplicação restrita dos privilégios, de um lado garante-se competição no setor (e igualdade na competição) e de outro se permite que a ECT receba um tratamento diferenciado, quando isso justificar as peculiaridades dos casos concretos, inclusive no que tange às características dos serviços prestados, preservando-se sua capacidade de seguir atuando como um dos grandes prestadores do mercado postal. Diante disso, e tendo em vista que o PL adota a separação por serviços, seria necessário lidar com o desafio de a rede postal ser única e, pois, de ter que ser diferenciada, conforme se tenha objetos postais prestados no regime público ou conforme se tenha objetos postais prestados no regime privado, o que nos remete à discussão desenvolvida no item IV.3 do Capítulo 2.

Ademais, também como forma de se aprimorar a ECT para competir com empresas privadas, disputando mercados em igualdade de condições, poderia ser prevista a fruição da estatal a um regime licitatório mais flexível, como o que a Lei do Petróleo disciplinou 
para a Petrobras, para que ele não constitua um entrave a que a estatal seja competitiva no mercado (art. 173, II) (V.2.3.1. deste Capítulo 3).

Dessa análise das principais linhas condutoras do PL, vê-se que em grande medida o projeto enfrenta os problemas do setor postal a partir da formulação de contribuições jurídicas focadas na heterogeneidade de regimes jurídicos aplicáveis ao setor, em vista da expansão das atividades postais e do aumento de prestadores no setor. Não se pretende com essa análise chegar à conclusão de que esse cenário constitui a melhor estratégia de reformulação do setor postal, mas certamente um dos cenários possíveis que podem vir a orientar uma futura reestruturação jurídica do setor, seja servindo de referencial ou de contraponto ao desenho regulatório que poderá ser implantado.

\section{V.5. Breve análise das perspectivas de reestruturação do setor postal no Brasil}

Mais do que propriamente analisar as regras propostas pelo modelo regulatório consubstanciado no PL n. ${ }^{\circ}$ 1.491/99, procurou-se chamar atenção no item anterior para o fato de que é possível adotar outros desenhos regulatórios, e mesmo para o fato de que, conforme analisado ao longo deste capítulo, do ponto de vista das normas atualmente aplicáveis ao setor postal, é possível interpretá-las e concatená-las de maneira mais adequada e funcional. Deveras, paralelamente ao projeto, que está em trânsito, de se formular um marco regulatório para o setor postal, a concatenação, articulação e interpretação coerentes da legislação atualmente existente já consegue mitigar em muito os problemas que comprometem o setor postal brasileiro.

No que tange a este aspecto de interpretação das normas aplicáveis ao setor, é importante, pois, lidar com o desafio de a jurisprudência do STF estar atualmente consolidada, de forma que o Tribunal exerça de maneira mais efetiva o papel que ele pode (e deve) exercer de melhorar/qualificar o debate, e de fortalecer a participação popular, as regras do jogo democrático. Ao longo desta dissertação de mestrado, procurou-se demonstrar que muito do debate existente apresenta falhas de consistência e de coerência, o que prejudica a consolidação de uma jurisprudência consistente sobre a matéria, e a sistematização que se poderia esperar de um Tribunal que exerce um papel tão importante no direito brasileiro. Ao que parece, a jurisprudência ainda titubeia sobre a conceituação de serviço público, atividade econômica e "monopólio", e sobre a aplicação de um ou vários regimes jurídicos, em vista das diferentes atividades postais, dos prestadores que atuam no 
setor e das características do Estado brasileiro. Isso acaba gerando diversas indefinições, acerca do papel dos prestadores em regime público e em regime privado, que não são benéficas para o setor como um todo.

Em paralelo a esta necessidade de o STF interpretar o arcabouço jurídico aplicável ao setor postal de maneira mais consistente e funcional, parece estar o debate, em alguma medida hoje em curso, de se desenvolverem novas ferramentas para o setor, que forneçam condições para que novas soluções sejam adotadas para resolver os problemas setoriais.

Diante disso, admitindo-se como verdadeira a premissa de que há razões jurídicas a levarem o poder público a concretizar um movimento de reestruturação do setor postal brasileiro, parte-se dos pressupostos segundo os quais (i) não há uma fórmula universal para estabelecer as regras do jogo para o setor, isto é, que as "estratégias" num cenário hipotético podem ser livremente adotadas (eis que nem a legislação, nem a jurisprudência vinculam uma possível reestruturação setorial); (ii) o direito atualmente aplicável ao setor postal não tem cumprido de maneira eficiente sua função, mas pode (e deve) ter um papel essencial de criar condições institucionais para que políticas públicas se desenvolvam; e (iii) a formulação de contribuições sólidas para o setor (legítimas e eficientes) merece um enfoque distinto da leitura literal de qual é o real significado do verbo "manter" da Constituição (CF, art. 21, X), da tradicional dicotomia serviços públicos versus atividades econômicas e mesmo de análises alinhadas apenas a concepções políticas de qual é o melhor modelo de Estado (se mais ou menos intervencionista).

Neste contexto, faz sentido a reflexão ampla em torno de possíveis cenários de reformulação do setor postal brasileiro, que poderiam ser mais ou menos "liberalizantes", a depender do modelo regulatório que se pretende implantar. O presente estudo, como já salientado, não tem o objetivo de analisar esses possíveis cenários (tendo sido objeto de pesquisa somente o PL n. ${ }^{\circ}$ 1.491/99), mas pretende chamar atenção para o fato de que é necessário que se retome a discussão mais ampla sobre a avaliação geral de estratégias de reformulação do setor, que pode ser mais enriquecida com a análise de questões como as seguintes, tratadas, especialmente do ponto de vista jurisprudencial, ao longo desta dissertação:

a) Que tipo de abordagem e de visão de serviço público é funcionalmente mais adequada para pautar os debates relacionados ao setor postal?

b) Todas as atividades postais devem ter necessariamente a natureza jurídica de serviço público (a partir da dicotomia serviços públicos versus atividades 
econômicas) e serem submetidas a um único regime jurídico? Há razões jurídicas para se dividir a cadeia produtiva dos serviços postais (pode-se cogitar repartir o ciclo postal nas seguintes fases: recebimento, expedição, transporte e entrega de objetos postais) ou as atividades que compõem a rede postal (em razão da essencialidade dos serviços e de seu conteúdo econômico), sujeitando-as a regimes jurídicos moldados às distintas necessidades de regulação dos serviços?

c) Como lidar com o desafio de elaborar políticas públicas consistentes para o setor postal, que prevejam as pautas e metas para a organização da exploração dos serviços postais no Brasil? Os vetores para essa elaboração pressupõem, a partir de um diagnóstico do potencial de mercado e do volume de depósitos (faturamento) que os serviços e as redes geram, definir e hierarquizar objetivos prioritários para o setor, lidar com os interesses contrapostos de diversos grupos de interesse, definir claramente o papel a ser desempenhado por cada um desses grupos (por exemplo, caso se defina que franquias podem atuar no setor, faz sentido pensar num conselho de franquias que incentive medidas propositivas), monitorar as atividades constantemente, definir que áreas do Brasil são deficitárias de atendimento postal e como nelas abrir novos postos de atendimento (dentro da garantia de universalização dos serviços).

d) A elaboração de políticas públicas para o setor postal pressupõe necessariamente a alteração da legislação postal? Como conferir ao STF o ônus de concatenar, articular e interpretar de forma coerente a legislação existente? A elaboração de políticas públicas setoriais implica em aceitar que do ponto de vista normativo e regulatório inexiste uma estrutura minimamente adequada para um setor da relevância do postal e que o Tribunal não tem a exclusividade na formulação de argumentos constitucionais e no encerramento dos debates públicos de grandes questões constitucionais? $?^{289}$

\footnotetext{
${ }^{289}$ Sobre o tema, ver Daniel A. Farber, "Legislative Constitutionalism in a System of Judicial Supremacy", in Richard Bauman / Tsvi Kahana (eds.), The Least Examined Branch: The Role of Legislation in the Constitutional State, p. 431-451. O autor chama atenção para o fato de que há muitas matérias que não estão propriamente na Constituição, mas que são "materialmente constitucionais", razão pela qual poderíamos falar em direito constitucional no Legislativo. Neste sentido, seguindo sua linha de raciocínio exposta no artigo, atribuir a tarefa de "reserva de justiça" apenas ao Tribunal (que se autointitula como o guardião da Constituição, detentor da palavra final), seja por desconfiança dos outros Poderes (em especial do legislador), seja pela ideia de que apenas os Tribunais poderiam decidir corretamente, parece empobrecer o debate público, tão caro à democracia.
} 
e) Há razões jurídicas para deixar-se de unificar o regime jurídico aplicável aos prestadores do setor postal, inclusive à ECT, passando-se a identificar o regime jurídico no caso concreto, a partir da relevância do serviço envolvido para atingir fins públicos, e em vista do serviço estar ou não sendo prestado em regime de competição? (o regime jurídico aplicável aos prestadores, inclusive à ECT, passaria a variar conforme as atividades por ela desempenhadas e de acordo com a necessidade de o Estado regulá-las - por exemplo, as atividades são prestadas em regime de competição? Quais bens e serviços públicos devem ser preservados com os privilégios da impenhorabilidade de bens e da imunidade tributária?).

f) Há razões jurídicas para se manter o "monopólio" postal, em toda a rede de serviços ou em parte dela, na linha da decisão do STF? Se a resposta for positiva, há necessidade de se editar uma lei que delimite claramente o alcance do monopólio, tornando possível que as diversas atividades postais sejam a ela claramente subsumidas? Se a resposta for negativa, é necessário planejar o setor de tal modo que sejam construídos mecanismos regulatórios capazes de lidar com o desafio da universalização do setor?

g) Há razões jurídicas para manter-se num único ente da Administração Pública (a ECT) a concentração dos papéis de planejamento, execução, normatização, fiscalização e regulação do setor postal? Seria o caso de se pensar em um modelo em que uma agência reguladora assuma os serviços postais (como no modelo adotado no PL n. ${ }^{\circ}$ 1.491/99)? Em que medida essa concentração gera problemas de governança à ECT, no que tange à transparência com que a estatal se apresenta à sociedade e em relação ao planejamento e regulação do setor?

h) Qual é o futuro da ECT em eventual reestruturação do setor? Como capacitar a estatal para competir com empresas privadas (o que já vem sendo pensado, sob o ponto de vista gerencial)? 


\section{CONCLUSÃO}

O presente estudo procurou fazer um mergulho na especificidade do setor postal brasileiro, através da análise de peculiaridades centrais para o tratamento e disciplina deste setor da economia. A constatação que levou à elaboração deste trabalho é a de que o setor postal é um campo importante e repleto de dificuldades, mas em grande medida tem sido negligenciado como campo de análise e reflexão, o que prejudica a identificação de soluções para os problemas setoriais.

Foi dito na Introdução que o objetivo que se queria buscar no trabalho era revelar os problemas e gargalos jurídicos do setor, com a consequente indicação de possíveis soluções para resolvê-los.

A hipótese central do trabalho era a de que o regime jurídico do setor postal se constrói a partir da atuação da ECT mais do que de qualquer outro referencial, o que poderia constituir um problema considerando que há outros agentes econômicos atuando no setor.

A conclusão final da pesquisa, que confirma a hipótese central do trabalho, é a de que o regime jurídico do setor postal se constrói predominantemente a partir da atuação da ECT. O regime jurídico do setor tem sido delimitado a partir das políticas públicas voltadas à ECT, dos serviços postais por ela prestados e das decisões judiciais em que a estatal é autora ou ré, o que lhe confere um regime jurídico privilegiado e protetivo. A análise de todo esse arcabouço jurídico revela que, em grande medida, objetiva-se preservar a empresa pública ECT, em detrimento da avaliação do quadro maior do setor postal brasileiro. Esse entrave do setor leva à reflexão sobre a possibilidade de serem adotadas novas soluções para resolvê-lo, que podem abarcar desde soluções interpretativas a uma revisão do quadro normativo atualmente aplicável ao setor.

Para testar a validade dessa hipótese e chegar a essa conclusão final foi necessário analisar como o setor tem sido tratado na legislação, doutrina e jurisprudência, diagnosticando-se as consequências da falta de clareza do regime setorial.

O corpo do trabalho foi dividido em três capítulos.

No Capítulo 1, a pesquisa foi iniciada com a descrição da realidade do setor postal no Brasil. Buscou-se identificar o momento do surgimento da ECT, a partir da transformação do DCT, e o contexto atual de prestação do serviço postal, marcado pela 
significativa ampliação dos serviços postais, com o surgimento de uma verdadeira "rede postal". Observou-se, também, a proliferação de prestadores no setor, com a profusão de agências próprias dos correios, em paralelo a agências franqueadas, permissionárias, comunitárias e empresas privadas de distribuição. Demonstrou-se que cada um desses prestadores tem características próprias, submetidos a regimes jurídicos bastante diferentes entre si. Alguns estabeleceram com a ECT um vínculo contratual, para expansão de sua rede de atendimento (caso das franqueadas, permissionárias e agências comunitárias), enquanto que outros passaram a conviver competitivamente com a estatal, sem qualquer vínculo de outorga ou parceria (caso das empresas de courier).

O caminho percorrido na sequência voltou-se à análise do que o setor postal representa no cenário atual das comunicações brasileiras. Imaginava-se, em linha com a hipótese do trabalho, e restou comprovado, que as políticas públicas setoriais confundemse em grande medida com as políticas voltadas à ECT e que há um déficit de planejamento para o setor. A este respeito, verificou-se que o núcleo das discussões do GTI e posteriores medidas aprovadas pela medida provisória n. ${ }^{\circ}$ 532/11, convertida na lei n. ${ }^{\circ}$ 12.490/11, claramente voltou-se para a gestão da ECT, tendo ficado num plano secundário a avaliação do quadro maior do setor postal brasileiro. Além disso, mesmo as medidas adotadas para a ECT mostraram-se planejadas de maneira insuficiente. Nesse contexto, concluiu-se que as políticas voltadas à ECT, a despeito de terem seu mérito, não têm o condão de assumir o espaço existente para as políticas públicas do setor, considerando a existência de outros agentes em regime de competição com o prestador estatal. É necessário, assim, que uma política pública mais abrangente determine objetivos claros e precisos, com prazos definidos e meios para empreendê-los.

Verificado um cenário de descaso em relação ao setor postal, foram identificados três vetores que denotam a sua importância e a necessidade de existir uma preocupação institucional para com ele, quais sejam: (i) a amplitude dos serviços postais, que revela ainda hoje sua importância estratégica; (ii) as ações sociais e relevância econômica da empresa pública ECT; e (iii) a grande capilaridade do serviço postal ao longo do país. Objetivou-se com isso demonstrar que há razões suficientes para que políticas relacionadas ao setor postal façam parte da agenda nacional, ou seja, para que a estatal em si e o setor como um todo deixem de ser colocados em segundo plano pelos órgãos governamentais.

O Capítulo 2 pautou-se na constatação de que houve uma ampliação dos serviços postais e de que é fundamental para a análise do setor conhecer o conteúdo dos serviços 
prestados como postais e a operacionalização de sua cadeia. Subjacente a este capítulo está a ideia segundo a qual do alargamento dos serviços postais derivam efeitos jurídicos, eis que o regime jurídico de determinado setor da economia é concebido considerando o núcleo material dos serviços que presta. Serviram de pano de fundo para a análise fundamentalmente duas questões: o que são serviços postais, e quais efeitos jurídicos derivam da ampliação dos serviços prestados como postais.

O ponto de partida para responder a essas indagações foi a análise da legislação postal. O foco da análise foi fundamentalmente a lei n. $^{\circ} 6.538 / 78$, única que traz uma delimitação dos serviços, destinada, no entanto, especificamente a delinear o objeto de exploração da ECT. Constatado que a lei se distancia da realidade de serviços prestados no setor, tendo em vista a sua crescente complexidade, a pesquisa optou por investigar quais são os serviços oferecidos à sociedade pela ECT. Esse mapeamento possibilitou ter uma visão mais clara dos serviços englobados na "rede postal", e concluir que, dada a abrangência e diversidade dos serviços e a agilidade com que mudanças têm sido implantadas no setor (alinhadas às novas tendências do tráfego postal e aos "novos negócios”), há uma grande dificuldade de se delimitar o conteúdo dos serviços postais. Tal dificuldade acarreta diretamente consequências negativas ao regime jurídico aplicável à atividade.

Registrou-se então que, do ponto de vista operacional, seguindo o que a legislação preconiza, a ECT se utiliza de quatro sub-redes do ciclo postal (recebimento, expedição, transporte e entrega de objetos postais), numa rede postal única, configuração que torna-se particularmente importante diante da possibilidade de incidências regulatórias distintas sobre etapas da cadeia de atividades econômicas (em sentido amplo) ou por modalidades de serviços. Demonstrou-se que, dada a forma como tem ocorrido a acomodação de empresas no setor postal, a organização do regime semicompetitivo no setor tem características de uma divisão por serviços. Não obstante, verificou-se que ainda é necessário estabelecer mais claramente a organização desse regime semicompetitivo ou competitivo, se assim se entender adequado, e especialmente quais serviços postais podem comportar prestação segundo parâmetros de mercado (em vista de suas condições estruturais e tecnológicas) e em qual extensão.

Assinalou-se que a separação por serviços implica na necessidade de diferenciaremse claramente os regimes jurídicos incidentes sobre cada serviço, a depender do objeto postal. Assim, conforme se tenha objetos postais prestados no regime público (aplicáveis à 
ECT os privilégios da impenhorabilidade de bens e da imunidade tributária recíproca) e conforme se tenham objetos postais prestados no regime privado (inaplicável o regime privilegiado), evitam-se problemas práticos que atualmente existem no setor. Como consequência, a pesquisa demonstrou a necessidade de serem criados mecanismos que não necessariamente passem por soluções estruturais, mas que possibilitem à estatal competir em determinados serviços em igualdade com as demais prestadoras privadas (o que implica em lidar com o fato de a rede postal ser única). Seria reservado à ECT um regime específico e mais protetivo na medida do necessário pelos serviços de caráter público que presta à coletividade - de acordo com o objeto postal.

A pesquisa então se pautou na diferenciação dos serviços postais em relação aos diferentes graus de essencialidade, conteúdo econômico e possibilidade de se sujeitarem à competição. Concluiu-se que, tendo em vista esses critérios e tomando por base o funcionamento do setor, passa a ser possível discutir e analisar a possibilidade de se identificar o regime jurídico aplicável à estatal e aos demais prestadores a partir do caso concreto, em vista dos serviços prestados.

O Capítulo 3, por sua vez, formou o núcleo central do trabalho. Ele foi estruturado para atingir o objetivo central da pesquisa, qual seja, revelar os problemas e gargalos jurídicos do setor, chamando atenção para a possibilidade de serem adotadas novas soluções para resolvê-los. Serviram de base para tal intento as informações obtidas sobre a realidade do setor postal no Brasil (Capítulo 1) e sobre o conteúdo dos serviços postais (Capítulo 2).

O capítulo partiu da investigação geral do que se considera "serviço público", dado que a discussão em torno da natureza jurídica do serviço postal depende em grande medida do debate mais amplo acerca deste conceito. Assinalaram-se as principais características da dicotomia serviços públicos versus atividades econômicas, apresentando o debate em curso na atualidade. Identificou-se uma tendência de se repensar a validade dessa distinção, a partir de uma concepção de serviço público que engloba atividades relevantes e de interesse coletivo (sem depender do regime jurídico através do qual são prestadas), e da constatação de que inexiste um regime jurídico único e geral para os serviços públicos e tampouco para as atividades econômicas.

A partir disso, o capítulo foi repartido em três eixos centrais do regime jurídico dos serviços postais: (i) a natureza jurídica dos serviços postais, (ii) a interdição dos particulares à prestação de parte dos serviços postais (enfoques centrais do trabalho), e (iii) 
a discussão mais ampla sobre a importância do planejamento e dos arranjos jurídicoinstitucionais do setor.

O estudo caminhou no sentido de identificar os limites constitucionais e legais do serviço postal, concluindo que a Constituição não restringiu as opções do legislador, e que atualmente há na legislação expressa referência ao serviço postal como serviço público. Essas conclusões deram suporte à análise crítica da natureza jurídica dos serviços postais na doutrina e na jurisprudência.

Após uma incursão na formulação doutrinária sobre a natureza jurídica do setor postal, constatou-se que ela tende a privilegiar uma leitura literal da Constituição (especificamente do verbo "manter", contido em seu art. 21, X), ao considerar o serviço postal como serviço público "por determinação/definição constitucional”.

Criticou-se essa formulação, pois, partindo-se da dicotomia serviços públicos versus atividades econômicas, para que as empresas privadas de distribuição pudessem explorar serviços postais, deveriam ter participado de um certame licitatório, ao final do qual celebrassem com o poder público um contrato de concessão ou permissão. Questionou-se, então, se faz sentido extrair do texto constitucional a natureza jurídica do setor postal, desconsiderando-se a realidade de prestação dos serviços.

Analisou-se, a partir disso, o tratamento que o STF tem dado ao tema da natureza jurídica dos serviços postais, tendo por base as decisões da Corte relacionadas aos privilégios da impenhorabilidade de bens e da imunidade tributária recíproca. Concluiu-se que a validação desses privilégios à ECT fundamenta-se em grande medida no entendimento da Corte de que a estatal é prestadora de serviço público, posicionamento esse que parte da dicotomia serviços públicos versus atividades econômicas, e em grande medida da leitura do texto constitucional. A partir disso, demonstrou-se que a jurisprudência tem consagrado e propagado um regime jurídico único, fortemente publicístico, aplicável a todas as atividades integrantes da rede postal, o que traz problemas práticos para o setor.

Foi revelada uma dificuldade prática de os ministros delimitarem o conteúdo do serviço postal, mas, a despeito disso, verificou-se que o que se extrai dos resultados dos acórdãos é a unificação do regime jurídico aplicável à ECT, prestadora de serviço público, com o que a jurisprudência em grande medida desconsidera a complexidade dos serviços da rede postal e os diferentes agentes econômicos que atuam no setor. Tem-se aplicado um 
mesmo regime jurídico, desconsiderando-se que o núcleo material dos serviços postais é distinto.

Demonstrou-se também a necessidade de se avaliar a função dos privilégios postais e seu impacto sobre a competição no setor.

Em relação ao privilégio da impenhorabilidade de bens, viu-se que o STF privilegia o enquadramento genérico dos bens da ECT como públicos, em detrimento da verificação de quais são os bens da estatal que estão empregados diretamente no cumprimento de sua atividade fim de interesse público. Esse raciocínio levou a se concluir que a preocupação da Corte volta-se em maior medida a preservar a empresa pública ECT, independentemente da natureza das atividades que explora e dos bens a ela afetados.

Em relação à imunidade tributária, de maneira semelhante, verificou-se que a função de se conferir à ECT este privilégio ficou num plano secundário nas discussões entre os ministros, cujo argumento central para a extensão das regras imunizantes à estatal é o fato de ela ser prestadora de serviço público, o que mais uma vez levou à conclusão de que a preocupação da Corte volta-se em maior medida a preservar o funcionamento da ECT nos moldes atuais. Verificou-se ainda que a argumentação dos ministros relacionouse apenas indiretamente aos objetivos de se perseguir o princípio federativo e a igualdade entre as pessoas políticas.

Ademais, demonstrou-se que o enquadramento genérico dos bens da estatal como afetados a serviços públicos e, pois, a impenhorabilidade genérica dos bens da ECT, e a incidência das regras imunizantes a todo o "patrimônio, renda e serviços" da estatal apresentam-se problemáticos na medida em que podem trazer prejuízos à competição no setor. Isso ocorre especialmente porque, conforme se verificou na análise da ADPF n. ${ }^{\circ}$ 467, é possível interpretar que o Tribunal excluiu impressos e encomendas não apenas do regime de exclusividade conferido à ECT como também do regime de serviço público.

Verificou-se também que o fundamento dos votos tende a ser pouco alinhado com a realidade do setor, além de deixar de enfrentar problemas sérios - como a existência de competição. Isso faz com que exista um "setor paralelo", com regime jurídico indefinido, à margem da lei e da regulamentação. Ademais, constatou-se que tais entendimentos jurisprudenciais impactam diretamente sobre o regime jurídico aplicável às franquias postais, que na seara legislativa vêm ganhando nova disciplina, acompanhada de diversos debates e questionamentos. 
Fundamentalmente, assim, em relação a esse eixo de análise (natureza jurídica dos serviços postais), o trabalho concluiu que o STF validou um regime jurídico protetivo à ECT, a partir da unificação do regime jurídico que lhe é aplicável. Desconsiderou-se, com isso, a complexidade dos serviços da rede postal, a existência de diferentes agentes econômicos que atuam no setor, e que o núcleo material dos serviços postais é distinto.

A partir disso, adotada como eixo de análise a interdição dos particulares à prestação de parte dos serviços postais, a pesquisa caminhou no sentido de dizer que inexiste um "monopólio" postal constitucional, o que confere ao legislador ampla margem para a normatização do setor. Identificou-se o alcance do "monopólio" postal, tomando por base sua delimitação legal (lei n. ${ }^{\circ}$ 6.538/78), para então analisar criticamente o julgamento da ADPF n. ${ }^{\circ} 46-7$, sem dúvida um dos mais paradigmáticos do setor, que recepcionou o "monopólio" postal. Essa análise crítica foi estruturada a partir dos problemas práticos vislumbrados por conta da recepção do "monopólio" postal, tal como ocorreu no julgamento.

Constatou-se que a despeito de as previsões legais terem sido recepcionadas, há uma clara dificuldade de as atividades atualmente prestadas como serviços postais se subsumirem na prática às prescrições da antiga lei n..$^{\circ}$ 6.538/78, editada numa época em que a complexidade das atividades postais e os atores eram sensivelmente diversos. Uma vez chamado a se pronunciar a respeito da delimitação do "monopólio", em decisão final o STF não delimitou claramente o campo que seria livre à exploração das empresas privadas (quais serviços estariam fora do "monopólio" postal), razão pela qual os conflitos tendem a se perpetuar ao longo do tempo. Concluiu-se que, ainda que não seja papel do Tribunal definir precisamente os serviços que devem ser prestados exclusivamente pela ECT, caberia a ele dar uma interpretação mais funcional à legislação, concatenando-a e articulando-a em vista da realidade setorial e ao regime constitucional aplicável, pois seu posicionamento não foi capaz de trazer ao setor efetiva segurança jurídica.

Verificou-se que em grande medida foi feita uma correlação entre a natureza jurídica de serviço público do serviço postal e sua prestação "monopolista", o que foi questionado. A conclusão foi de que o fato de uma determinada atividade ter sido eleita à condição de serviço público não implica necessariamente sua exploração exclusiva pelo Estado. Inexistente uma exclusividade automática e a imperatividade da prestação direta, surge um maior ônus argumentativo por parte daqueles que defendem que os Correios 
devem atuar "monopolisticamente", debate que, no entanto, não foi explorado no julgamento.

Questionou-se ainda a correlação entre exclusividade na prestação do serviço e sua prestação universal. Verificou-se que o tema do subsídio cruzado para a prestação universal dos serviços postais foi analisado de maneira bastante superficial no julgamento, bem como ficou num plano secundário a questão de saber se de fato ele é necessário para manter o setor. Com isso, de maneira geral, deixou-se de lado a análise mais ampla sobre a possibilidade de serem adotados no setor outros mecanismos voltados à universalização dos serviços, como a criação de fundos setoriais.

Constatou-se uma contradição entre a natureza jurídica de serviço público da rede postal e a decisão final da ADPF. Uma vez que é possível interpretar que o STF autorizou as empresas privadas a explorarem as atividades relacionadas a impressos e encomendas livremente, em regime de mercado (em razão da interpretação conforme ao art. 42 da lei n. ${ }^{\circ}$ 6.538/78 e do fato de as empresas privadas seguirem atuando normalmente), a Corte parece ter retirado dos "serviços postais" (serviço público) as atividades competitivas (impressos e encomendas). Isso contradiz o entendimento manifestado pelo STF de que todos os serviços prestados como postais são serviços públicos.

Chamou-se atenção para a dificuldade de operacionalização da fiscalização do setor postal, em razão das incertezas sobre se as empresas privadas atuam de maneira legítima e sobre quais atividades podem prestar.

Concluiu-se, por fim, que é necessário avaliar a função do "monopólio" postal, sob um ponto de vista mais funcional e aplicado, pois esse estado de incertezas no mercado postal pode criar entraves à evolução tecnológica do setor e, com isso, ao próprio desenvolvimento do país.

Em relação a esse eixo de análise (interdição dos particulares à prestação de parte dos serviços postais), na mesma linha do que se concluiu em relação à natureza jurídica dos serviços postais, verificou-se que o STF validou um regime jurídico protetivo à ECT.

A partir disso, a pesquisa concentrou-se na análise da proposta do PL n. ${ }^{\circ}$ 1.491/99, que veiculou um modelo regulatório diferente do aplicável atualmente. Constatou-se que em grande medida o projeto propõe enfrentar os problemas do setor postal a partir da formulação de contribuições jurídicas focadas na heterogeneidade de regimes jurídicos a 
ele aplicáveis, em vista da expansão das atividades postais (e da diversidade do conteúdo dos serviços) e do aumento de prestadores no setor.

Concluiu-se, então, que esse é um dos cenários que podem vir a orientar uma futura reestruturação jurídica do setor postal, seja como referencial ou contraponto ao desenho regulatório que poderá ser implantado no Brasil. Outros desenhos regulatórios podem ser adotados em eventual reformulação do setor, mas é necessário que se retome uma discussão mais ampla sobre a avaliação geral de estratégias de reformulação.

Paralelamente a este projeto de se formular um marco regulatório para o setor postal, concluiu-se que a concatenação, articulação e interpretação coerentes da legislação atualmente existente já mitigam em muito os problemas que comprometem o setor postal brasileiro. Muito do debate existente, especificamente no STF, apresenta falhas de consistência e de coerência, o que prejudica a consolidação de uma jurisprudência consistente sobre a matéria, e a sistematização que se poderia esperar de um Tribunal que exerce um papel tão importante no direito brasileiro. 


\section{REFERÊNCIAS BIBLIOGRÁFICAS}

AGUILLAR, Fernando Herren. Controle social de serviços públicos. São Paulo: Max Limonad, 1999.

ALMEIDA, Fernando Dias Menezes de. "Aspectos constitucionais da concessão de serviços públicos”. In: MEDAUAR, Odete (coord.). Concessão de serviço público. São Paulo: Revista dos Tribunais, 1995, p. 23-37.

Anteprojeto de Lei Orgânica da Administração Pública Federal e Entes de Colaboração, acompanhado da Exposição de Motivos. Elaborado pela Comissão instituída pela portaria n. ${ }^{\circ} 426$, de 6 de dezembro de 2007, do Ministério do Planejamento, Orçamento e Gestão.

ARAGÃO, Alexandre Santos de. Direito dos serviços públicos. $2^{\mathrm{a}}$ ed. Rio de Janeiro: Forense, 2008.

BANDEIRA DE MELLO, Celso Antônio. Curso de direito administrativo. $18^{\mathrm{a}}$ ed. São Paulo: Malheiros, 2005.

BARROSO, Luís Roberto. "Regime constitucional do serviço postal: legitimidade da atuação da iniciativa privada". Revista de Direito Administrativo, n. ${ }^{\circ} 22$, Rio de Janeiro, out./dez. 2000, p. 179-212.

BOBBIO, Norberto. Da estrutura à função: novos estudos de teoria do direito. Tradução de Daniela Beccaccia Versiani; revisão técnica de Orlando Seixas Bechara e Renata Nagamine. Barueri, SP: Manole, 2007.

BUCCI, Maria Paula Dallari. "O conceito de política pública em direito”. In: BUCCI, Maria Paula Dallari (org.). Políticas públicas: reflexões sobre o conceito jurídico. São Paulo: Saraiva, 2006, p. 1-49.

CARNEIRO, Maria Neuensjchwander Escosteguy. Uma nova visão do setor postal brasileiro. Rio de Janeiro: Lumen Juris, 2006.

CARrAZZA, Roque Antonio. Curso de direito constitucional tributário. $21^{\mathrm{a}}$ ed. São Paulo: Malheiros, 2005. 
COMPARATO, Fábio Konder. "Ordem econômica na Constituição brasileira de 1988”, Revista de Direito Público, n. ${ }^{\circ}$ 93, ano 23, São Paulo, RT, jan./mar. 1990, p. $263-$ 276.

CORTEZ, Tiago Machado. Moeda, Estado e Direito: o papel do Estado na ordem monetária e seu controle. 227 f. Tese (Doutorado em Direito) - Faculdade de Direito, Departamento de Direito Econômico e Financeiro, Universidade de São Paulo, São Paulo, 2004.

COSTÓDIO FILHO, Ubirajara. O serviço postal no direito brasileiro. Curitiba: JM, 2006.

COUTINHO, Diogo Rosenthal. "Entre eficiência e eqüidade: a universalização das telecomunicações em países em desenvolvimento". Revista Direito GV, v. 2, São Paulo, 2005, p. 137-160.

. "A universalização do serviço público para o desenvolvimento como uma tarefa da regulação". In: SALOMÃO FILHO, Calixto (coord.). Regulação $e$ desenvolvimento. São Paulo: Malheiros, 2002, p. 65-86.

; FARACO Alexandre Ditzel; PEREIRA NETO, Caio Mário da Silva. "Universalização das telecomunicações no Brasil: uma tarefa inacabada". Revista de direito público da economia, ano 1, n. ${ }^{\circ}$ 2, Belo Horizonte, abr./jun. 2003, p. 1384.

DI PIETRO, Maria Sylvia Zanella. Direito administrativo. 23 ${ }^{\mathrm{a}}$ ed. São Paulo: Atlas, 2010.

- Parcerias na Administração Pública: concessão, permissão, franquia, terceirização, parceria público-privada e outras formas. $6^{a}$ ed. São Paulo: Atlas, 2008.

Exposição de Motivos EMI n. ${ }^{\circ}$ 89/MC/MF/MOG, referente ao Projeto de Lei Geral do Sistema Nacional de Correios (Projeto de Lei n. ${ }^{\circ}$ 1.491, de 1999).

FARBER, Daniel A. "Legislative Constitutionalism in a System of Judicial Supremacy", in Richard Bauman / Tsvi Kahana (eds.), The Least Examined Branch: The Role of Legislation in the Constitutional State. Cambridge: Cambridge University Press, 2006, p. 431-451. 
FRANCO SOBRINHO, Manuel de Oliveira. "Regime jurídico das empresas públicas no Brasil”. Revista de Direito Público, ano III, v. 12, São Paulo, Revista dos Tribunais, abr./jun. 1970, p. 14-39.

GRAU, Eros Roberto. A ordem econômica na Constituição de 1988. 11 a ed. São Paulo: Malheiros, 2006.

GROTTI, Dinorá Adelaide Musetti. O serviço público na Constituição Brasileira de 1988. São Paulo: Malheiros, 2003.

"O regime jurídico das empresas estatais". In: WAGNER JUNIOR, Luiz Guilherme da Costa (coord.). Direito Público: estudos em homenagem ao professor Adilson Abreu Dallari. Belo Horizonte: Del Rey, 2004, p. 125-179.

JUSTEN FILHO, Marçal. Curso de direito administrativo, 5ª ed. São Paulo: Saraiva, 2010.

MANKIW, N. Gregory. Introdução à economia. Tradução de Allan Vidigal Hastings e Elisete Paes e Lima; revisão técnica de Carlos Roberto Martins Passos e Manuel José Nunes Pinto. São Paulo: Cengage Learning, 2009. Tradução da $5^{\text {a }}$ edição norte-americana.

MARQUES NETO, Floriano de Azevedo. "Reestruturação do setor postal brasileiro". Revista Trimestral de Direito Público, v. 19, São Paulo, 1997, p. 149-169.

. “Concessão de serviço público sem ônus para o usuário”. In: WAGNER JUNIOR, Luiz Guilherme da Costa (coord.). Direito Público: estudos em homenagem ao professor Adilson Abreu Dallari. Belo Horizonte: Del Rey, 2004, p. 331-351.

. Regulação estatal e interesses públicos. São Paulo: Malheiros, 2002.

- “As contratações estratégicas das estatais que competem no mercado". In: OSÓRIO, Fábio Medina; SOUTO, Marcos Juruena Villela (coords.). Direito administrativo: estudos em homenagem a Diogo de Figueiredo Moreira Neto. Rio de Janeiro: Lumen Juris, 2006, p. 575-604.

. O regime jurídico das utilidades públicas: função social e exploração econômica dos bens públicos. 593 f. Tese (Livre-Docência em Direito) - Faculdade de Direito, Departamento de Direito do Estado, Universidade de São Paulo, São Paulo, 2008.

. Bens públicos: função social e exploração econômica. O regime jurídico das utilidades públicas. Belo Horizonte: Fórum, 2009. 
MARQUES NETO, Floriano de Azevedo. "A nova regulação dos serviços públicos". Revista de Direito Administrativo, v. 228, Rio de Janeiro, abr./jun. 2002, p. 13-29. Agências reguladoras independentes: fundamentos e seu regime jurídico. Belo Horizonte: Fórum, 2005.

MEDAUAR, Odete. Direito administrativo moderno. $13^{\mathrm{a}}$ ed. São Paulo: Revista dos Tribunais, 2009.

MONTEIRO, Vera. Concessão. São Paulo: Malheiros, 2010.

Notícia "BB desbanca Bradesco e leva Banco Postal", matéria de autoria de Sofia Fernandes, publicada no jornal Folha de São Paulo (dia $1^{\circ}$ de junho de 2011, B4).

Notícia "Contratos de franquias dos Correios são prorrogados por sete meses", matéria de autoria de Rafael Bitencourt e André Borges, publicada no jornal Valor Econômico em 11 de outubro de 2010. Disponível em: $<$ http://clippingmp.planejamento.gov.br/cadastros/noticias/2010/10/11/contratosde-franquias-dos-correios-sao-prorrogados-por-sete-meses>. Acesso: 30/10/2010.

Notícia "Correios busca melhoria na parceria com franqueados", de 27 de julho de 2011. Disponível em: <http://blog.correios.com.br/correios/2011/07/27/correios-buscamelhoria-na-parceria-com-franqueados/>. Acesso: 19.12.2011.

Notícia "Correios mantêm interesse no trem-bala", de 15 de julho de 2011. Disponível em: <http://www.estadao.com.br/estadaodehoje/20110715/not_imp745122,0.php>. Acesso: 18.07.2011.

Notícia "Correios mantêm monopólio sobre serviços postais", de 5 de agosto de 2009, de autoria de Felipe Seigman e Larissa Guimarães. Disponível em: <http://www1.folha.uol.com.br/fsp/dinheiro/fi0608200912.htm>.

Acesso: 28/06/2010.

Notícia (Editorial) "Correio Político", publicado no jornal Folha de São Paulo (dia 29 de junho de 2010, A2).

Notícia “Correios registram lucro de R \$ 499,6 mi no semestre", de 14 de julho de 2011, de autoria de Eduardo Rodrigues (Agência Estado). Disponível em: $<$ http://economia.estadao.com.br/noticias/negocios+geral,correios-registram-lucrode-r-4996-mi-no-semestre,75978,0.htm>. Acesso: 20.12.2011. 
Notícia "Correios vão poder vender celular e comprar avião", matéria de autoria de Andreza Matais, Natuza Nery e Márcio Falcão, publicada no jornal Folha de São Paulo (dia 29 de abril de 2011, A9).

Notícia “Disputa entre Sabesp e ECT pelo direito de emitir boletos", de 17 de dezembro de 2008, de autoria de Clarissa Ferreira de Melo Mesquita e José Roberto Manesco. Disponível em: <http://www.migalhas.com.br/mostra_noticia.aspx?cod=75502>. Acesso: 28/06/2010.

Notícia "Governo inclui Correios no trem-bala", matéria de autoria de Leonardo Souza e Andreza Matais, publicada no jornal Folha de São Paulo (dia 3 de fevereiro de 2011, B1).

Notícia “Governo muda Correios para evitar 'apagão"”, publicada no jornal Folha de São Paulo (dia 9 de outubro de 2010. Caderno Poder, A9).

Notícia "Leilão para banco parceiro dos Correios será no dia 31 de maio", publicada no jornal Folha de São Paulo (dia 30 de abril de 2011, B16).

Notícia "MP que cria Correios S.A. deve sair hoje", de março de 2010. Disponível em: <http://www1.folha.uol.com.br/fsp/dinheiro/fi3103201026.htm>.

Acesso: 30.06.2010.

Notícia "Modernização dos correios prevê agências no exterior", de 8 de fevereiro de 2010. Disponível em: $<$ http://economia.estadao.com.br/noticias/economia,geral,modernizacao-doscorreios-preve-agencias-no-exterior,not_4317.htm>. Acesso: 28.06.2010.

Notícia "Monopólio dos Correios voltará à pauta do STF", matéria de autoria de Josette Goulart, publicada no jornal Valor Econômico (dia 07 de abril de 2011). Disponível em: $<$ https://conteudoclippingmp.planejamento.gov.br/cadastros/noticias/2011/4/7/mon opolio-dos-correios-voltara-a-pauta-do-stf/>. Acesso: 08.08.2011.

Notícia “Monopólio postal”, publicada no jornal O Estado de São Paulo (dia 8 de maio de 2006, A3).

Notícia "O que fizeram com os Correios", matéria de autoria de Maria Inês Dolci, publicada no jornal Folha de São Paulo (dia 28 de junho de 2010, B8). 
Notícia "Procuradoria denuncia Jefferson e mais oito por escândalo dos Correios", de 11 de setembro de 2008.2 Disponível em: <http://www1.folha.uol.com.br/folha/brasil/ult96u443813.shtml>.

Acesso: 19.12.2011.

Notícia "STF amplia prazo para franquias dos Correios", publicada no jornal Folha de São Paulo (dia 13 de junho de 2009. Caderno Dinheiro, B3).

Notícia "Um novo correio?". Disponível em: <http://www.estadao.com.br/estadaodehoje/20100216/not_imp511787,0.php>. Acesso: 29.06.2010.

NUSDEO, Ana Maria de Oliveira. "Agências reguladoras e concorrência”. In: SUNDFELD, Carlos Ari (coord.). Direito administrativo econômico. São Paulo: Malheiros, 2006, p. 159-189.

NUSDEO, Fábio. Curso de economia: introdução ao direito econômico. $4^{\mathrm{a}}$ ed. São Paulo: Revista dos Tribunais, 2005.

ORTIZ, Gaspar Ariño. “La empresa pública: teoría y práctica. Líneas de reforma”. In: Principios de derecho público econômico. $3^{\mathrm{a}}$ ed. - Lección decimotercera. Granada: Comares, 2004, p. 397-444.

PINTO JUNIOR, Mario Engler. O estado como acionista controlador. $516 \mathrm{f}$. Tese (Doutorado em Direito) - Faculdade de Direito, Departamento de Direito Comercial, Universidade de São Paulo, São Paulo, 2009.

PINTO, Henrique Motta. Empresa estatal: modelo jurídico em crise? 200 f. Dissertação (Mestrado em Direito) - Faculdade de Direito, Departamento de Direito do Estado, Pontifícia Universidade Católica de São Paulo, São Paulo, 2010.

Projeto de Lei Geral do Sistema Nacional de Correios (Projeto de Lei n. ${ }^{\circ}$ 1.491, de 1999),

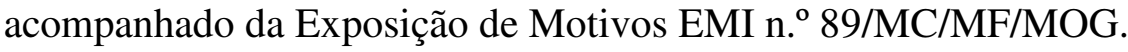

"Relatório Empresarial e Social da ECT de 2008". Disponível em: $<$ http://www.correios.com.br/institucional/conheca_correios/relatorios_publicacoe s/relatorios_empresariais/2008/Relatorio_ECT_2008.pdf>. Acesso: 22.06.2010. 
Relatório "Balanço Social dos Correios 2005". Disponível em: $<$ http://www.correios.com.br/institucional/conheca_correios/balanco_social/arquiv o/balanco_social_2005[2].pdf>. Acesso: 22.06.2010.

SILVA, Laura de Paula. Primeiro prêmio do concurso epistolar 2006. Comunidade Chico Mendes, Amazonas, 19 de março de 2006. Disponível em: <http://www.upu.int/letter_writing/en/letters/2006_en.pdf>. Acesso: 04.10.2008.

SUNDFELD, Carlos Ari. "Meu depoimento e avaliação sobre a lei geral de telecomunicações". Revista de Direito de Informática e Telecomunicações, ano 2, n. ${ }^{\circ}$ 2, Belo Horizonte, jan./jun. 2007, p. 55-84.

. "Introdução às agências reguladoras”. In: SUNDFELD, Carlos Ari (coord.). Direito administrativo econômico. São Paulo: Malheiros, 2006, p. 17-38.

; SOUZA, Rodrigo Pagani de. "Licitação nas estatais: levando a natureza empresarial a sério". Revista de Direito Administrativo, v. 245, Rio de Janeiro, 2007, p. 13-30.

; SOUZA, Rodrigo Pagani de. "A superação da condição de empresa estatal dependente". Revista de Direito Público da Economia, n. 12, Belo Horizonte, outubro a dezembro de 2005, p. 9-49.

TÁCITO, Caio. “As empresas públicas no Brasil”. Revista de Direito Administrativo, v. 84, Rio de Janeiro, FGV, abr./jun. 1966, p. 432-439.

TRUBEK, David. Law and development in a time of multiple visions: the challenge of law in the new developmental State. Mimeo., março de 2008.

VIEIRA, Oscar Vilhena. Supremo Tribunal Federal: jurisprudência política. $2^{\mathrm{a}}$ ed. São Paulo: Malheiros, 2002.

VOJVODIC, Adriana de Moraes. Nos labirintos do STF: em busca do conceito de serviço público. Trabalho de final de curso, Escola de Formação, Sociedade Brasileira de Direito Público, São Paulo, 2006. Disponível em: <http://www.sbdp.org.br/arquivos/monografia/76_Adriana\%20Vojvodic.pdf>. Acesso: 15.08.2010.

WALDRON, Jeremy. Law and Disagreement. Oxford: Oxford University Press, 1999, p. 232-254 (cap. 11: "Participation: The Right of Rights"). 
Decisões e normas referidas no item II (Metodologia), especialmente nos subitens II.1 e II.2. Site <http://www.correios.com.br/>. Acesso: 22.06.2010.

Sites referidos ao longo da pesquisa. 


\section{ANEXOS}

A seguir é apresentado o relato dos casos do STF referentes à impenhorabilidade de bens, à imunidade tributária recíproca e ao "monopólio" postal que subsidiaram as discussões do Capítulo 3 da dissertação.

\section{A. OS CASOS DA IMPENHORABILIDADE DOS BENS DA ECT}

Em 15 de setembro de 1998 a Primeira Turma do STF julgou o RE n. ${ }^{\circ}$ 222.0415/RS em que a ECT questionava decisão do Tribunal Superior do Trabalho (TST) que havia recusado a ela o direito de ser executada judicialmente pelo regime de precatórios. No STF, a ECT sustentava que só poderia se sujeitar à execução mediante precatório, não apenas por força da impenhorabilidade de seus bens - genericamente prevista no decretolei n. ${ }^{o}$ 509/69, que a criou -, mas também pela redação do art. 100 da Constituição, dado cuidar-se de empresa pública delegatária da União no exercício do monopólio do serviço postal, que a essa última confiou o art. $21, \mathrm{X}$.

O ministro Ilmar Galvão, relator, não conheceu do recurso, tendo sido acompanhado pelos demais membros da Turma sem quaisquer reservas. Seus fundamentos para decidir foram os seguintes: (i) o pagamento de débitos resultantes de sentença judiciária por meio de precatório, regulado pelo art. 100 e parágrafos da CF de 1988 é sistema aplicável somente às entidades de direito público; (ii) o art. 173, §1º , II da CF é óbice insuperável, vedando a aplicação do processo dos precatórios à execução de débitos judiciais de responsabilidade dos entes da Administração Pública de natureza privada (óbice inclusive já existente quando da edição do decreto-lei n. ${ }^{\circ} 509 / 69$, cf. $§ 2^{\circ}$ do art. 163 da CF/67 reproduzido ipsis literis no $§ 2^{\circ}$ do art. 170 da EC 1/69); (iii) o decreto-lei n. ${ }^{\circ}$ 509/69 não estabelecia nenhuma ressalva em consideração à natureza jurídica do serviço prestado pela empresa pública, e o regime de monopólio previsto apenas possibilitava a instituição, em favor da empresa pública, de privilégios de ordem fiscal, os quais foram suprimidos pela CF/88; (iv) a ECT é empresa delegatária de serviço cuja manutenção incumbiu à União (art. 21, X); não presta, no entanto, serviço público inerente ao Estado, mas atividade econômica; (v) a atividade econômica é exercida pela ECT em forma de monopólio estatal, o que não pode conferir à ECT posição privilegiada em face das 
empresas privadas, efeito que decorreria do art. 12 do decreto-lei n. ${ }^{\circ}$ 510/69, no ponto em que instituiu para a empresa regime específico, diverso do previsto para as empresas privadas em geral, ao gravar todos os seus bens, rendas e serviços com a cláusula da impenhorabilidade; e (vi) o art. 12 do decreto-lei n. ${ }^{\text {5 }}$ 510/69 é incompatível com os textos constitucionais.

Em 16 de novembro de 2000 o Plenário do STF julgou cinco recursos extraordinários (RE n. ${ }^{\circ}$ 220.906-9/DF; RE n. 225.011-0/MG; RE n. ${ }^{\circ}$ 229.696-7/PE; RE n. ${ }^{\circ}$ 230.072-3/RS e RE n. ${ }^{\circ}$ 230.051-6/SP), firmando a partir daí entendimento diverso do julgamento anterior, segundo o qual os bens, rendas e serviços da ECT são impenhoráveis. Em todos esses casos, a ECT recorria de decisões da justiça do trabalho que conferiam aos credores da estatal a garantia de que seus créditos seriam adimplidos através da execução direta da estatal, sob pena de penhora de seus bens. Em todos os casos, a estatal pretendia ver reconhecido pelo STF o direito de que seus débitos fossem executados pelo regime de precatórios (execução que observaria as normas relacionadas à execução contra a Fazenda Pública, constantes dos artigos 100 da Constituição e 730 e 731 do Código de Processo Civil). Após longo debate, o Plenário do STF, por maioria de votos, conheceu e deu provimento aos recursos extraordinários, vencidos os ministros Ilmar Galvão, Marco Aurélio Mello e Sepúlveda Pertence.

O ministro Maurício Corrêa, relator, proferiu o voto condutor da tese vencedora no STF. As razões que o levaram a votar pela recepção do decreto-lei n. ${ }^{\circ}$ 509/69 e, pois, pela conferência de privilégios à ECT como a impenhorabilidade de seus bens, rendas e serviços foram as seguintes: (i) a ECT é pessoa jurídica equiparada à Fazenda Pública, que explora serviço de competência da União (CF, art. 21, X), atividade tipicamente estatal; (ii) a restrição contida no art. $173, \S 1^{\circ}$ da $\mathrm{CF} / 88$ não é aplicável às entidades estatais exploradoras de serviços públicos; (iii) a ECT presta serviço público mantido pela União; (iv) seus bens são impenhoráveis por pertencerem à entidade estatal mantenedora (o orçamento da estatal é aprovado pelo Ministério do Planejamento e Orçamento e sua receita é constituída de subsídio do Tesouro Nacional).

Em linha com a tese do ministro Maurício Corrêa foi o voto do ministro Nelson Jobim, que defendeu que por definição constitucional, o serviço postal é um serviço que integra os fins do Estado. Segundo ele, "É, por isso e por opção positivada na norma constitucional, um serviço público". Nessa linha, chamou atenção para o fato de os bens da ECT serem afetados ao serviço público, essa seria a pedra de toque da questão, o fato de 
eles serem "bens do patrimônio administrativo". Também integraram essa linha decisória os votos dos ministros Sydney Sanches, Moreira Alves e Carlos Velloso.

A linha decisória que acabou sendo minoritária foi conduzida pelo ministro Ilmar Galvão. Na linha do seu posicionamento anterior, ele votou pelo não conhecimento do RE e declaração da inconstitucionalidade da expressão "impenhorabilidade de seus bens, rendas e serviços", contida no art. 12 do decreto-lei n. ${ }^{\circ}$ 509/69. Em aditamento ao voto, o ministro chamou atenção para dois pontos importantes: (i) para o fato de que se aceita a alegação de que o serviço postal prestado pela ECT não é atividade econômica, mas serviço público inerente ao Estado, ele não poderia ser prestado por particulares, mediante contrato, o que segundo ele não ocorria; (ii) o ministro chamava atenção para a exploração do serviço por meio de franchising: "Nunca vi serviço essencial do Estado prestado por particular. A cidade de Brasília está cheia de agências dos Correios particulares, porque não é um serviço essencial do Estado. Este serviço, no Brasil, é exercido pela União em regime de monopólio"; (iii) a criação pelo STF de empresa pública de direito público (o que seria incompatível com o ordenamento jurídico); e (iv) as dificuldades práticas de se processar o sistema de precatórios em face da ECT, que como empresa pública, entidade de direito privado, não tem orçamento.

A essa tese aproxima-se o voto do ministro Marco Aurélio, que chamava atenção para os seguintes pontos: (i) em razão de as empresas públicas serem pessoas jurídicas de direito privado, seus bens não poderiam ser enquadrados como bens públicos; (ii) o regime jurídico do pessoal da ECT é o da CLT, o que revelaria sua submissão às regras próprias das empresas privadas quanto aos débitos existentes. A esse respeito, o ministro Ilmar Galvão chamava atenção para uma contradição no pronunciamento que estava sendo fixado pelo STF: “...o Estado cria uma empresa pública, contrata servidores e os despede quando bem entender. Agora, na hora de responder pelos débitos, não é empresa pública; mas, sim, autarquia".

Uma terceira linha decisória relaciona-se ao voto do ministro Sepúlveda Pertence, voto vencido (não conheceu do RE). Seu voto pode ser considerado intermediário, em razão de ter ele entendido que haveria um problema no decreto-lei tendo em vista que ele havia conferido à ECT privilégio da impenhorabilidade universal de seu patrimônio e não apenas dos bens afetados ao serviço público. Segundo o ministro, havia inconstitucionalidade no art. 12 do decreto-lei n. ${ }^{\circ} 509 / 69$ por (i) prescrever a impenhorabilidade das rendas da ECT; e (ii) no que dizia respeito aos seus bens, para ele 
poderiam ser considerados impenhoráveis os bens afetos ao serviço postal e telegráfico. Entendia ser inaplicável à ECT o art. 100 da Constituição e que a execução de seus débitos deveria fazer-se mediante o direito comum, através de penhora dos bens não afetados ao serviço público que lhe é delegado, incluídas as suas rendas.

A tese levantada pelo ministro Ilmar Galvão, segundo a qual se o STF entendesse que os credores da ECT não poderiam efetuar penhora, eles ficariam completamente descobertos, em razão da impossibilidade de processar-se o regime de precatórios, gerou uma longa discussão entre os ministros. Sua tese respaldava-se no fato de que a ECT havia instituído um sistema informal de precatório, cujo processamento ficava a critério da administração da empresa, não havendo nenhuma lei que o disciplinasse. Isto porque a mecânica da execução mediante precatório pressupunha que a entidade devedora fosse dotada de orçamento legal e anual de despesas, do qual não dispunham as empresas públicas ou sociedades de economia mista. Para alguns ministros, a solução prática disso era interpretação conforme à Constituição (ministro Nelson Jobim); para outros era impossibilitar a utilização desse mecanismo por empresas públicas, sob pena de os credores das estatais ficarem completamente a descoberto (ministros Ilmar Galvão, Marco Aurélio e Sepúlveda Pertence).

Outra questão que ensejou debate por parte dos ministros foi a prestação do serviço postal por empresas privadas. Quem levantou essa questão foi o ministro Marco Aurélio. O ministro Moreira Alves afirmava ser crime “...utilizar-se de terceiros para efeito de correspondência". O ministro Marco Aurélio então lembrou que havia o serviço de entrega no próprio STF. Diante disso, o ministro Moreira Alves afirmou que “...foi uma construção no sentido de que não se trata de correspondência no sentido dado pela Constituição". O ministro Ilmar Galvão lembrava também que existiam as agências dos correios exploradas pelo sistema de franchising, espalhadas por todo o Brasil. O ministro Sepúlveda Pertence alegava que essas franquias eram concessões, obviamente. O ministro Moreira Alves questionava então: "Pergunto: então, isso seria o quê? Concessão de serviços públicos?”. O ministro Ilmar Galvão não concordava: "O serviço é explorado por particular". O ministro Moreira Alves então encerra o debate: "E há mais. Quem edita selos? Essa é uma atividade do Estado. São os Correios, e só ele pode fazê-lo, o que demonstra tratar-se de monopólio do Estado. Não é possível, por exemplo, uma empresa particular emitir selos".

Em 12 de dezembro de 2000, a Primeira Turma do STF julgou o Recurso Extraordinário n. ${ }^{\circ}$ 220.699-3/SP. A ECT recorria de decisão do TST que lhe negara o 
direito de ter o pagamento de seus débitos trabalhistas através de precatório. $\mathrm{O}$ ministro Moreira Alves, relator, conheceu do recurso e lhe deu provimento em face do precedente do RE n. ${ }^{\circ}$ 220.906. A decisão foi unânime, nos termos do seu voto. Segundo ele, com esse julgamento, o STF havia recebido pela atual Constituição o decreto-lei $n^{\circ}$ 509/69, que estende à ECT os privilégios conferidos à Fazenda Pública, dentre os quais o da impenhorabilidade de seus bens, rendas e serviços. Nesse sentido, a execução contra ela deveria fazer-se mediante precatório, sob pena de ofensa ao disposto no art. 100 da CF/88. No mesmo sentido foi a decisão do Recurso Extraordinário n. ${ }^{\circ}$ 229.961-2/MG, julgado no mesmo dia e também relatado pelo ministro Moreira Alves.

Em 17 de abril de 2001, a Segunda Turma do STF julgou o Agr. Regimental no Recurso Extraordinário n. 230.161-6/CE, em que o Município de Fortaleza entendia que a ECT não podia abrigar-se nas disposições do decreto-lei 509/69 para desfrutar das prerrogativas conferidas à Fazenda Pública, dentre elas, a impenhorabilidade de seus bens, em detrimento das disposições da lei n. ${ }^{\circ}$ 6.830/80, que lhe era posterior. O ministro Néri da Silveira, relator, conheceu do recurso, mas lhe negou provimento, sob o fundamento de que a jurisprudência do STF reconhecia à estatal a impenhorabilidade de seus bens. Nos termos do seu voto, por unanimidade, o Tribunal negou provimento ao agravo.

Em 12 de junho de 2001, a Segunda Turma do STF julgou o Recurso Extraordinário n. ${ }^{0}$ 220.907-5/RO. Em processo de execução trabalhista, o juiz de primeira instância de Rio Branco, Acre, havia determinado a expedição de mandado de citação, avaliação e penhora dos bens da ECT, no prazo de 48 horas. As decisões do Tribunal Regional do Trabalho (TRT) e do Tribunal Superior do Trabalho (TST) lhe tinham sido desfavoráveis, em vista do que ela recorria ao STF, através de RE. Sustentava que (i) por ser empresa pública prestadora de serviço público, a execução contra ela deveria obedecer à regra do art. 100 da Constituição; (ii) ao considerar o serviço postal um dever do Estado, o legislador havia atribuído à ECT privilégios e prerrogativas especiais, como a impenhorabilidade de seus bens (decreto-lei n. ${ }^{\text {o } 509 / 69) ; ~(i i i) ~ o ~ a r t . ~ 21, ~ X ~ d a ~ C F / 88 ~}$ confere à União a competência para manter o serviço postal e o correio aéreo nacional; e (iv) pertencendo à União o capital da ECT, deveria ser observado o instituto do precatório. Nos termos do voto do ministro relator Carlos Velloso, por unanimidade, o STF conheceu do recurso e lhe deu provimento.

O ministro Carlos Velloso, relator, julgou o caso com base nos seguintes fundamentos: (i) seria preciso distinguir as empresas públicas exploradoras de atividade 
econômica (sujeitas ao regime jurídico próprio das empresas privadas), das prestadoras de serviços públicos (cuja natureza é de autarquia e às quais não se aplica o art. $173, \S^{\circ} \mathrm{da}$ Constituição); (ii) a ECT é empresa pública prestadora de serviço público, o serviço postal $(\mathrm{CF}$, art. $21, \mathrm{X})$, razão pela qual não se equipara às empresas privadas e integra o conceito de fazenda pública; seus bens não poderiam ser penhorados, estando ela sujeita à execução própria das pessoas públicas (CF, art. 100); e (iii) o STF havia fixado entendimento segundo o qual o decreto-lei n. ${ }^{\circ}$ 509/69 era compatível com a Constituição, razão pela qual os bens, rendas e serviços da ECT eram impenhoráveis, devendo a execução proposta contra ela, empresa pública prestadora de serviço público, fazer-se mediante precatório.

Poucos dias depois, em 19 de junho de 2001, o ministro Carlos Velloso conduziu, com base nesse precedente, o julgamento do Recurso Extraordinário n. ${ }^{\circ}$ 229.444-8/CE. Nos termos do seu voto, a unanimidade da Segunda Turma não conheceu do recurso.

Em 26 de junho de 2001, a Segunda Turma do STF julgou o Edcl. no Agrg. no Recurso Extraordinário n. ${ }^{\circ}$ 204.635-3/RS, em que questionava-se decisão do STF que negara provimento a agravo regimental sob a alegação de que a Corte havia pacificado entendimento segundo o qual o decreto-lei n. ${ }^{\text {o }}$ 509/69 era compatível com a ordem constitucional vigente e, por essa razão, eram impenhoráveis os bens, rendas e serviços de empresa pública exploradora de serviço monopolizado, devendo a execução fazer-se mediante precatório.

O embargante alegava em seu favor que o acórdão havia sido omisso a respeito dos fundamentos que levaram ao entendimento segundo o qual o decreto-lei n. ${ }^{\circ}$ 509/69 havia sido recepcionado pela Constituição de 1988, tendo em vista que os precedentes mencionados na decisão ainda não haviam sido publicados. Pedia que o STF explicitasse os fundamentos adotados nos precedentes mencionados, que ainda não haviam transitado em julgado. O ministro Maurício Corrêa, relator, rejeitou os embargos de declaração, tendo sido acompanhado pela Turma sem quaisquer reservas.

As razões que levaram o ministro a votar dessa forma foram as seguintes: (i) a publicação do acórdão que serviu de fundamento à decisão embargada não é imprescindível, nos termos da jurisprudência do STF; e (ii) o Plenário do STF havia

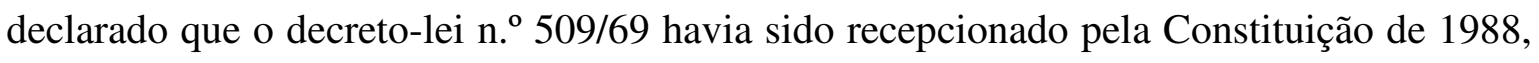
tendo entendido que os bens da ECT, empresa pública mantida pela União, seriam impenhoráveis, devendo a execução da condenação que lhe foi imposta fazer-se mediante precatório. 
Em 25 de setembro de 2001 a Segunda Turma do STF julgou o Agrg. no Agravo de Instrumento n. ${ }^{\circ}$ 313.854-0/CE interposto pelo Município de Fortaleza contra despacho do Ministro Néri da Silveira, sob o argumento de que a concessão de privilégios da Fazenda Pública à ECT não poderia ser aceita, constituindo-se foco de tratamento desigual a uma empresa que possui natureza privada e não pode se elidir às consequências dessa qualidade. O ministro conheceu do agravo regimental, mas lhe negou provimento, baseado no julgamento do RE n. 220.906 e em outros julgados do Tribunal. Nos termos do seu voto, a unanimidade da Turma negou provimento ao agravo regimental.

Em 05 de fevereiro de 2002, a Primeira Turma do STF julgou o Agrg. no Recurso Extraordinário n. ${ }^{\circ}$ 265.139-7/RS em que a agravante sustentava que o precedente citado no despacho agravado não havia sido publicado e que a ECT, por ser uma empresa pública, deveria se submeter ao regime jurídico próprio das empresas privadas, respondendo com seu patrimônio pelas obrigações assumidas. Em seu voto, a ministra Ellen Gracie, relatora, sustentou que o julgamento do RE n. 220.906 havia sido público e que o Plenário do STF, naquela ocasião, havia firmado jurisprudência contrária ao pedido da agravante, razão pela qual seu recurso havia se tornado inviável. Nos termos do voto da relatora, sem quaisquer reservas, a Turma negou seguimento ao agravo regimental no RE.

Em 12 de março de 2002, a Primeira Turma do STF julgou o Recurso Extraordinário n. ${ }^{\circ}$ 336.685-8/MG, interposto contra decisão do TST, que havia negado provimento ao agravo regimental sob o fundamento de que a empresa pública exerce atividade manifestamente econômica, submetendo-se ao mesmo regime de execução previsto para as empresas privadas. O ministro Moreira Alves, relator, fundamentou seu voto no precedente do RE n. ${ }^{\circ} 220.906$, no qual o STF havia decidido que o decreto-lei n. ${ }^{\circ}$ 509/69 havia sido recepcionado pela Constituição de 1988. O decreto-lei havia estendido à ECT os privilégios conferidos à Fazenda Pública, dentre os quais a impenhorabilidade de seus bens, rendas e serviços, razão pela qual a execução contra ela deveria fazer-se mediante precatório, sob pena de ofensa ao disposto no art. 100 da Constituição. Nos termos do seu voto, a Turma conheceu do Recurso e lhe deu provimento.

No mesmo dia, a Primeira Turma do STF julgou o Edcl. no Recurso Extraordinário n. ${ }^{\circ}$ 220.902-3/PE, no qual questionava-se o julgamento de RE a partir das seguintes alegações: (i) teria havido omissão no julgamento do RE quanto aos fundamentos adotados no RE n. ${ }^{\circ} 220.906$, que havia sido citado como precedente; (ii) o decreto-lei n. ${ }^{\circ}$ 509/69 havia transformado o antigo Departamento de Correios e Telégrafos em empresa 
pública, que deveria se sujeitar ao regime das empresas privadas, inclusive quanto à legislação trabalhista, na qual inexiste o precatório. Nos termos do voto do ministro Moreira Alves, relator, a Turma, por unanimidade, rejeitou os embargos de declaração no RE.

As razões que o levaram a assim decidir foram as seguintes: (i) o acórdão embargado havia dado os fundamentos da decisão prolatada pelo Plenário do STF ao julgar o RE n. 220.906 (a recepção do decreto-lei n. ${ }^{\circ}$ 509/69 pela Constituição de 1988, que havia estendido à ECT os privilégios conferidos à Fazenda Pública, dentre os quais a impenhorabilidade de seus bens, rendas e serviços, razão pela qual a execução contra ela só poderia ser feita mediante precatório, sob pena de ofensa ao art. 100 da Constituição); e (ii) o STF havia fixado entendimento segundo o qual a não publicação de precedente referido na decisão não impede que se julgue com base nele, se os fundamentos do acórdão forem sintetizados na decisão recorrida.

No dia 21 de maio de 2002 o STF julgou o Edcl. no Agravo de Instrumento n. ${ }^{\circ}$ 363.017-1/SP, no qual questionava-se despacho proferido com fundamento no RE n. $^{\circ}$ 220906. Nos embargos alegava-se que (i) a matéria dos autos não poderia ser decidida através de despacho do relator, pois o acórdão que havia servido de precedente para sua decisão ainda não havia sido publicado, o que inviabilizava o pleno exercício do direito de defesa; (ii) o relator deveria aguardar a publicação do precedente do Plenário do STF para proferir sua decisão; e (iii) os bens da ECT são penhoráveis, como o de qualquer outra empresa pública.

Em seu voto, a ministra Ellen Gracie acolheu os embargos de declaração como agravo regimental, mas lhe negou provimento, diante dos seguintes fundamentos: (i) o julgamento do RE n. ${ }^{\text {o } 220.906}$ havia sido público e havia respeitado os ditames constitucionais; (ii) nesse julgamento, o STF, mesmo por maioria de votos, posicionou-se favoravelmente à tese da embargada (ECT); e (iii) o despacho recorrido havia resumido a

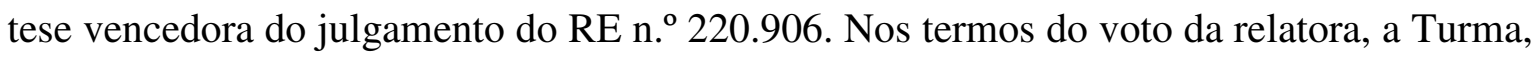
por unanimidade de votos, converteu os embargos de declaração no agravo de instrumento em agravo regimental no agravo de instrumento, mas lhe negou provimento.

Em 10 de setembro de 2002, a Primeira Turma do STF julgou o Agravo Regimental na Petição n. ${ }^{\circ}$ 2.677-2/PI. Cinco meses antes, o ministro Moreira Alves havia deferido cautelar para cancelar a realização de um leilão em que seriam vendidos, em processo de execução trabalhista, o edifício sede da ECT em Teresina (PI), mais outros 
dois imóveis, vários computadores, condicionadores de ar, automóveis e caminhões no valor de sete milhões, setecentos e oitenta e seis mil, sessenta e quatro reais e setenta e seis centavos.

Seu despacho, agora agravado, havia se baseado nos seguintes fundamentos: (i) a iminência do leilão (previsto para 15 de abril de 2002) demonstrava o dano irreparável ou de difícil reparação; (ii) a execução da sentença contrariava a jurisprudência do STF, segundo a qual a execução contra a ECT deveria processar-se de acordo com o art. 100 da Constituição para a expedição de precatório; e (iii) o leilão poderia acarretar grave prejuízo à atividade da ECT no tocante ao serviço de correios e telégrafos, pois estava prevista inclusive a venda de sua sede na capital do Estado do Piauí. Com base nesses fundamentos, o ministro havia deferido cautelar suspendendo o leilão. Posteriormente, no julgamento do agravo regimental, o ministro Moreira Alves, relator, votou no sentido de ser referendado o despacho que dera, para deferir a cautelar. Referendado ele, considerava prejudicado o agravo regimental contra ele interposto. Nos termos do seu voto, a Turma, por unanimidade de votos, referendou o despacho que deferia a cautelar, julgando prejudicado o agravo regimental contra ele interposto.

Em 11 de junho de 2003, o Plenário do STF julgou o Emb. Decl. no Recurso Extraordinário n. ${ }^{o}$ 230.051-6/SP. A ECT havia interposto RE contra acórdão que, entendendo penhoráveis os bens de empresa pública, havia afastado o pagamento do débito por meio de precatório. No STF, o caso havia sido julgado pelo Plenário que, por maioria de votos, dele conheceu e lhe deu provimento. Contra essa decisão foram opostos embargos de declaração sob o fundamento de que existiam omissões a sanar, relacionadas à decisão de 16/11/2000. Fundamentalmente, questionava-se a certidão dessa decisão segundo a qual o ministro Celso de Mello estava ausente, após o que havia sido incluído seu voto dando provimento ao recurso, e afirmava-se que o acórdão não havia apreciado a questão à luz do art. $173, \S^{\circ}$ da Constituição, na redação da Emenda Constitucional n. ${ }^{\circ}$ 19/98. Os embargos de declaração foram rejeitados por unanimidade de votos, nos termos do voto do ministro Maurício Corrêa.

O ministro Maurício Corrêa fundamentou sua decisão com base nos seguintes argumentos: (i) o ministro Celso de Mello havia estado presente à sessão de 08 de agosto de 2000, tendo proferido voto; (ii) a declaração de impenhorabilidade dos bens da ECT relacionava-se ao fato de cuidar-se de empresa pública, mantida pela União Federal, a qual 
pertenciam os seus bens; e (iii) a ECT é prestadora de serviço público de competência do Estado.

Em 14 de outubro de 2003, a Segunda Turma do STF julgou o Emb. Decl. no Agravo de Instrumento n. ${ }^{\circ}$ 410.330-0/SP, no qual questionava-se decisão do ministro Nelson Jobim, através da qual havia reformado o entendimento do TST que havia indeferido a expedição de precatório para o pagamento de crédito devido pela ECT. O ministro havia fundamentado sua decisão no entendimento pacífico do STF de que a ECT teria o direito à execução de seus débitos trabalhistas pelo regime de precatórios, por se tratar de entidade que presta serviço público. O ministro Nelson Jobim, relator, rejeitou os embargos, tendo sido acompanhado pela unanimidade da Turma sem quaisquer reservas. $\mathrm{Na}$ decisão dos embargos, valeu-se dos seguintes fundamentos para decidir: (i) o relator poderia julgar as causas que versem sobre o mesmo tema, ainda que o precedente utilizado não tenha sido publicado (entendimento firmado pelo STF); e (ii) a jurisprudência do STF havia firmado entendimento segundo o qual a execução contra a ECT deve observar o regime de precatórios.

Em 10 de fevereiro de 2004, a Primeira Turma do STF julgou o Ag. Reg. no Agravo de Instrumento n. ${ }^{\circ}$ 243.250-6/RS, que questionava o entendimento do STF de que o decreto-lei n. ${ }^{\text {o } 509 / 69}$ havia sido recepcionado pela Constituição (que estendeu à ECT os privilégios conferidos à Fazenda Pública, dentre eles o da impenhorabilidade de seus bens, rendas e serviços, devendo a execução fazer-se mediante precatório, sob pena de vulneração ao disposto no art. 100 da $\mathrm{CF}$ ). Nos termos do voto do ministro Sepúlveda Pertence, relator, a Turma, por unanimidade de votos, negou provimento ao agravo regimental no agravo de instrumento.

Em 06 de setembro de 2005, a Primeira Turma do STF julgou o Ag. Reg. no Agravo de Instrumento n. ${ }^{\circ}$ 238.960-0/RS, em que mais uma vez questionava-se o entendimento do STF de que o decreto-lei fora recepcionado. O ministro Cezar Peluso, relator, negou provimento ao agravo regimental no agravo de instrumento, condenando a parte a pagar multa por litigância de má-fé. A decisão foi unânime. No mesmo sentido, foi a decisão do Ag. Reg. no Agravo de Instrumento n. 395.654-7/RS, de 14 de fevereiro de 2006, também julgada pela Primeira Turma e relatada pelo Ministro Cezar Peluso.

Em 29 de novembro de 2005, a Segunda Turma do STF julgou o Ag. Reg. no Recurso Extraordinário n. ${ }^{\circ}$ 344.975-3/RJ, através do qual se questionava decisão do ministro Gilmar Mendes de acordo com o qual o STF havia firmado entendimento segundo 
o qual a ECT teria direito à execução de débitos trabalhistas pelo regime de precatórios, por se tratar de entidade que presta serviço público. Em seu voto, o ministro Gilmar Mendes, relator, afirmou que o agravante não havia conseguido demonstrar o desacerto da decisão, fundada da jurisprudência da Corte, segundo a qual a ECT estaria sujeita ao regime de precatórios, quando da execução de seus débitos. Nos termos do seu voto, por unanimidade, a Turma negou provimento ao agravo. 


\section{B. OS CASOS DA IMUNIDADE TRIBUTÁRIA RECÍPROCA}

Em 22 de junho de 2004, a Segunda Turma do Tribunal julgou o RE n. ${ }^{\circ}$ 407.0995/RS, em que o município de São Borja estava executando a ECT pela falta de pagamento de impostos municipais. O Tribunal Regional Federal (TRF) havia negado à estatal o direito de gozar da imunidade tributária recíproca, decisão em face da qual a ECT interpôs o RE, sustentando que (i) o art. 173, $\S 2^{\circ}$ da Constituição seria aplicável exclusivamente às empresas públicas que exploram atividade econômica em regime de concorrência com o setor privado, não incidindo sobre a ECT, empresa pública federal prestadora de serviço público reservado à União; (ii) o art. 12 de decreto-lei n. ${ }^{\circ}$ 509/69 não teria sido revogado; (iii) os bens da ECT seriam públicos e, portanto, impenhoráveis e imprescritíveis; (iv) a ressalva à imunidade da União, de suas autarquias e fundações (CF, art. 150, VI, “a”, §3º), a impostos sobre o patrimônio, quando houver contraprestação ou pagamento de preços ou tarifas pelo usuário, seria aplicável exclusivamente à prestação de serviço público por particulares; e (v) que goza da imunidade prevista no art. 150, VI, a, da CF.

O ministro Carlos Velloso, relator, conheceu em parte do recurso e na parte conhecida deu-lhe provimento. Foi acompanhado pela unanimidade da Turma sem quaisquer reservas. Os argumentos centrais utilizados pelo ministro para decidir foram os seguintes: (i) o destinatário do art. 150 da CF é entidade estatal que explore atividade econômica $\left(\$ 3^{\circ}\right)$ ou em que haja contraprestação ou pagamento de preços ou tarifas pelo usuário $\left(\$ 2^{\circ}\right)$; (ii) a ECT faria jus ao benefício por tratar-se de prestadora de serviço público, o serviço postal, "serviço público de prestação obrigatória e exclusiva do Estado: $C F$, art. 21, X”; e (iii) as empresas públicas prestadoras de serviço público têm a natureza jurídica de autarquia, pelo que não poderiam ser equiparadas às empresas privadas e integrariam o conceito de fazenda pública. O conhecimento em parte do recurso deve-se ao fato de que o ministro afastou seu pronunciamento sobre a recepção ou não do art. 12 do decreto-lei n. ${ }^{o}$ 509/69, questão que segundo ele não estaria no cerne do debate. Segundo ele, a questão deveria ser tratada apenas do ponto de vista constitucional, pois para fins de caracterizar uma imunidade, pouco importa a legislação ordinária. Nesse sentido, em seu voto ele afirma: “A questão, portanto, não está no afirmar se o DL 509, de 20.03.69, artigo 12, teria sido recebido ou não pela CF/88. A questão está, sim no afirmar que a ECT está abrangida pela imunidade tributária do artigo 150, VI, a, da CF”. 
O RE n. ${ }^{\circ}$ 407.099-5/RS serviu de precedente para os julgamentos do RE . $^{\circ}$ 356.122-7/RS, do RE n. ${ }^{\circ} 354.897-2 / R S$, do RE n. ${ }^{\circ} 398.630-9 / S P$, do RE n. ${ }^{\circ}$ 428.8214/SP, do RE n. ${ }^{\circ}$ 437.889-2/RS e do Ag. Reg. no RE n. 357.291-1/PR. Serviu também de precedente para as decisões do RE n. ${ }^{\circ}$ 424.227-3/SC e do RE n. ${ }^{\circ}$ 364.202-2/RS. Nesses dois casos, porém, o STF negou provimento ao recurso, em face do entendimento segundo o qual a imunidade recíproca prevista no art. 150, VI, "a”, da Constituição somente é aplicável a impostos, não alcançando as taxas, que estavam sendo objeto de cobrança por parte dos municípios de Inbituba e de Viamão.

Em 25 de maio de 2005, a Primeira Turma julgou o Ag. Reg. no RE n. ${ }^{\circ}$ 328.8431/MG, interposto pelo Estado de Minas Gerais contra decisão singular do STF que, baseada nos entendimentos anteriores do Tribunal, concedeu imunidade tributária à ECT, impossibilitando que a Fazenda Pública do Estado de Minas Gerais lhe cobrasse Imposto sobre a Propriedade de Veículos Automotores (IPVA). A discussão central do acórdão refere-se a questões processuais (se a questão poderia ou não ser apreciada em sede de agravo), mas a questão da natureza jurídica dos serviços postais acabou gerando algum debate entre os ministros.

O ministro Marco Aurélio assinalou que "[a ECT] não é Fazenda, é empresa pública, pessoa jurídica de direito privado". A sua fala, o ministro Sepúlveda Pertence chamava atenção para a natureza jurídica dos serviços que presta: "Sim, que desempenha serviço público". Diante disso, o ministro Marco Aurélio pondera: "Mas exerce, também, atividade econômica". O ministro Carlos Ayres discorda: "Não, é exclusivamente pública", ao que é acompanhado pelo ministro Eros Grau: "É exclusivamente pública, até porque a própria Constituição o diz”. O ministro Marco Aurélio volta os olhos à previsão constitucional: "Não, a Constituição apenas revela, e isso vem de alvará da época do Império, que a União manterá o serviço". O ministro Eros Grau então encerra o debate: "Perdoe-me Vossa Excelência, acho que tenho a meu favor a doutrina. Posso enunciar quem diz que é serviço público".

Em 05 de outubro de 2006, o Plenário do STF julgou o Ag. Reg. na Ação Cível Originária n. ${ }^{\circ}$ 789-2/PI, o Ag. Reg. na Ação Cível Originária n. ${ }^{\circ}$ 814-7/PR e o Ag. Reg. na Ação Cível Originária n. ${ }^{\mathbf{7 6 5}-1 / R J}$. Os agravos regimentais foram interpostos pela ECT em face de decisões monocráticas em que o ministro Marco Aurélio havia denegado a concessão de tutela antecipada que impediria que os Estados do Piauí, Paraná e Rio de 
Janeiro, respectivamente, exigissem da ECT o recolhimento de valores a título de Imposto sobre a Propriedade de Veículos Automotores (IPVA).

Buscando que lhe fosse concedida a tutela, a ECT alegou que a conclusão do ministro tinha sido dissonante com o pacífico entendimento adotado pelo Tribunal segundo o qual, como empresa prestadora de serviço público obrigatório e exclusivo do Estado, estaria abrangida pela imunidade tributária recíproca. Defendia ainda estarem presentes os pressupostos autorizadores da medida. O Tribunal, por maioria, deu provimento ao agravo regimental, tendo sido vencidos os ministros Marco Aurélio e Ricardo Lewandowski.

No julgamento desses agravos os ministros se dividiram em três linhas decisórias. Uma linha que considerava que a prestação dos serviços postais é de atividade econômica. O ministro Marco Aurélio foi o defensor dessa posição. Entendia que seria aplicável à ECT o art. $173, \S 2^{\circ}$ da CF e o art. $150, \S 3^{\circ}$ da CF. O primeiro pelo fato de ter ela personalidade jurídica própria, integrar a administração indireta e ter natureza privada, e o segundo em razão de ele vedar a aplicação da imunidade quando se tem exploração de atividades econômicas regidas pelas normas aplicáveis a empreendimentos privados ou quando haja contraprestação ou pagamento de preços ou tarifas pelo usuário.

De outro lado, uma linha decisória que considerava que a prestação dos serviços postais é de serviço público, sem fazer qualquer ponderação em relação às diversas atividades por ele englobadas. Foi a posição dos ministros Eros Grau (que fundamenta seu voto no texto da Constituição: "Não tenho dúvida: a Constituição estabelece que o serviço postal é um monopólio estatal’), Carlos Ayres (em razão de ser o serviço postal uma atividade estratégica e genuinamente estatal, própria da integração e coesão nacional; e pelo fato de o reconhecimento da imunidade diminuir os custos da manutenção da empresa com sua frota de veículos) e de Cezar Peluso (que preferiu não antecipar juízo de valor em definitivo, aguardando o julgamento da ADPF n. ${ }^{\circ}$ 46-7/DF).

Numa linha intermediária podem-se englobar os posicionamentos dos ministros Ricardo Lewandowski e Joaquim Barbosa. Votaram em sentidos diversos, mas ambos chamaram atenção para a diversidade da rede postal. O primeiro acompanhou o voto do ministro Marco Aurélio por considerar que (i) a ECT hoje compete com a iniciativa privada no tocante à prestação de alguns serviços; (ii) ela exerce uma série de serviços que não são estritamente públicos (banco postal, dinheiro fácil, importa fácil); e (iii) deveria haver uma preocupação com as agências franqueadas, examinando-se se a isenção do IPVA se estenderia também às centenas de franqueadas do correio que, segundo ele, em 
geral exercem vários serviços em que competem efetivamente com as empresas privadas, razão pela qual teriam com a isenção uma condição privilegiada.

O ministro Joaquim Barbosa foi quem iniciou a divergência em relação ao voto do ministro Marco Aurélio, mas em seu voto considerou que a ECT é empresa pública que executa ao menos um conjunto de atividades de caráter público. Segundo ele, a estatal executa serviços que inequivocamente não são públicos nem se inseririam na categoria serviços postais, como a atividade bancária Banco Postal. Porém, ele entendeu que a ponderação deveria ser feita por ocasião do respectivo julgamento de mérito, tendo em vista que segundo a ECT “...os veículos cuja propriedade é tributada com o IPVA são usados para serviços de coleta, remessa ou entrega de correspondência, documentos, objetos, bens e valores".

Em 26 de abril de 2007, o Tribunal Pleno julgou o Ag. Reg. na Ação Cível Originária n..$^{\circ}$ 811-5/DF. Por meio do agravo, o Distrito Federal se manifestava contra decisão monocrática do Ministro Gilmar Mendes. O DF alegava que a ECT não poderia gozar da imunidade quanto a todos os seus bens e serviços, indistintamente, pelas seguintes razões: (i) a exclusividade da União na prestação do serviço postal não foi estabelecida pela CF (art. 21, X) e a Lei n. ${ }^{\circ}$ 6.538/1978 apenas qualifica como serviços públicos monopolísticos algumas das atividades desempenhadas pela ECT; (ii) a ECT realiza atividades de cunho notoriamente econômico, não enquadradas como serviço público.

O ministro Gilmar Mendes, relator do acórdão, negou provimento ao agravo, tendo sido acompanhado pelos demais ministros sem quaisquer reservas. Sua razão de decidir fundamentou-se na jurisprudência firmada no STF (inclusive para a concessão de tutela antecipada) pela qual às empresas públicas prestadoras de serviços públicos se aplicaria o $\S 2^{\circ}$ e não o $\$ 3^{\circ}$ do art. 150 da $\mathrm{CF}$. Sobre as alegações da agravante de que algumas atividades da ECT teriam nítida natureza econômica (como o Banco Postal e o Sedex), ressaltava que a natureza jurídica e a amplitude do conceito dos serviços postais prestados pela ECT estava em debate na ADPF n. ${ }^{\circ} 46$, sendo conveniente deixar a sua análise para o momento da apreciação do mérito dessa ação.

Em 22 de novembro de 2007, o Plenário do STF julgou o Ag. Reg. na Tutela Antecipada na Ação Cível Originária n. ${ }^{\circ}$ 912-8/MS, interposto pelo Estado do Mato Grosso do Sul contra decisão que havia concedido antecipação dos efeitos da tutela à ECT, para que se abstivesse do pagamento de IPVA. O ministro Ricardo Lewandowski, relator, negou provimento ao agravo regimental, tendo sido acompanhado pelos demais ministros. 
Suas razões de decidir foram as seguintes: (i) o STF estaria sistematicamente, em casos idênticos, deferindo o pedido de antecipação de tutela; e (ii) o STF teria se orientado no sentido de que o periculum in mora fica evidenciado pela simples possibilidade de apreensão dos veículos utilizados pela administração pública; no caso, a apreensão poderia inviabilizar a prestação dos serviços postais.

Em 17 de março de 2008, o Plenário do STF julgou o Ag. Reg. na Medida Cautelar na Ação Cível Originária n. 1.095-6/GO. O Estado de Goiás interpôs agravo regimental contra decisão do ministro Carlos Ayres, que havia deferido o pedido de antecipação parcial de tutela, suspendendo a exigibilidade do crédito de ICMS sobre o serviço de transporte de encomendas realizado pela ECT. O Estado sustentava (i) que a atividade da ECT não tinha por fim o transporte interestadual de mercadorias, motivo pelo qual não se enquadraria na definição de "serviços" de que trata a alínea "a" do inciso VI do art. 150 da CF; (ii) ausência de verossimilhança; e (iii) que haveria periculum in mora in reverso, residente nos danos irreparáveis causados ao Estado de Goiás pela parte dos créditos objeto da ação.

O ministro Gilmar Mendes, relator, votou pelo não provimento do recurso de agravo, tendo sido acompanhado pela maioria dos ministros. Mais uma vez, o ministro Marco Aurélio foi voto vencido sustentando que a ECT é pessoa jurídica de direito privado que explora atividade econômica. Para ele, empresa pública, pessoa jurídica de direito privado, não pode ser confundida com União, Estado, Município e Distrito Federal. Além disso, a previsão do art. $173, \S 2^{\circ}$ constituiria obstáculo à garantia de tratamento diferenciado às empresas públicas e sociedades de economia mista.

No mesmo dia o STF julgou a Ação Cível Originária n. ${ }^{\circ}$ 959-4/RN em que a ECT pedia que lhe fosse reconhecida a imunidade tributária recíproca prevista no art. 150, VI, “a”, da Constituição, com relação ao IPVA do Estado do Rio Grande do Norte, de modo a “...escapar de qualquer sanção pelo não recolhimento de IPVA, diante da propriedade de veículos utilizados no desempenho de suas atividades típicas...".

O ministro Menezes Direito entendeu que o caso comportava julgamento antecipado, por ser matéria exclusivamente de direito. Sua razão de decidir pautou-se na jurisprudência pacificada do STF no sentido de que (i) a ECT é empresa pública que presta serviço público e não atividade econômica; (ii) dessa peculiaridade advém sua natureza autárquica; e (iii) a distinção entre empresas públicas prestadoras de serviço público e empresas públicas exploradoras de atividade econômica não se limita ao art. 173 da CF, 
alcançando o art. 150 da CF (a excludente do $\S 3^{\circ}$ não poderia abarcá-la). O Tribunal, por maioria de votos, julgou procedente a ação.

O ministro fez referência à decisão da $\mathrm{ADPF}$ n. ${ }^{\circ}$ 46-7/DF, à época em tramitação, para afirmar que, independentemente da confirmação do monopólio da estatal, ela permaneceria como “...empresa pública constituída única e exclusivamente para a prestação dos serviços públicos de que cuida o art. 21, X, tudo assentado na jurisprudência específica desta Suprema Corte...”. No mesmo sentido, votou o ministro Carlos Ayres, chamando atenção para o fato de que, por não se tratar de atividade econômica, sobre a ECT não incide o art. 173, §1 $1^{\circ}$, II da CF. Em sentido contrário, foi o pronunciamento do ministro Marco Aurélio, na mesma linha dos seus pronunciamentos anteriores.

Em 16 de setembro de 2008, a Segunda Turma do STF julgou o Ag. Reg. no Agravo de Instrumento . $^{\circ}$ 718.646-1/SP, interposto contra decisão do ministro Eros Grau que havia negado seguimento ao agravo de instrumento, impossibilitando que o município de Santos cobrasse da ECT o Imposto Predial e Territorial Urbano (IPTU). O município alegava que (i) a ECT não goza de imunidade tributária recíproca por ser empresa pública federal com personalidade jurídica de direito privado; (ii) que a Constituição Federal, ao explicitar quais entes da Administração Indireta estavam abrangidos pela imunidade tributária, aludiu apenas a autarquias e fundações públicas, pelo que as empresas públicas e de economia mista ficaram de fora da incidência do art. 150, VI, a da CF; e (iii) a controvérsia dos autos não é pacífica no STF, sendo objeto de discussão na ADPF n. ${ }^{\circ}$ 46, pendente de julgamento. O ministro Eros Grau, relator, negou provimento ao agravo, tendo sido acompanhado pela unanimidade dos membros da Turma. Segundo ele, por meio dos demais julgados, o STF teria declarado a compatibilidade do decreto-lei n. ${ }^{\circ}$ 509/69 com a CF/88.

Em 17 de março de 2009, a Primeira Turma do STF julgou o Ag. Reg. no Agravo de Instrumento n. ${ }^{\circ}$ 690.242-0/SP, em que o município de Santos pedia a processamento do recurso extraordinário, ao qual havia sido negado seguimento ante o reconhecimento de que a imunidade recíproca dos entes políticos é extensiva à empresa pública prestadora de serviço público. O ministro Ricardo Lewandowski negou provimento ao agravo regimental (sem debates), e foi acompanhado pela unanimidade da Turma sem reservas.

Em 12 de maio de 2009, o STF julgou o Ag. Reg. na Ação Cautelar n. o 2.3246/RS, interposto contra decisão monocrática que havia indeferido a concessão de medida 
liminar para atribuição de efeito suspensivo a RE em que se discutia a incidência do Imposto sobre Serviços de Qualquer Natureza (ISSQN) sobre as atividades de franquia postal. A decisão agravada havia se apoiado em dois fundamentos: (i) a imunidade tributária recíproca não se aplicaria aos empreendimentos privados e àqueles em que haja contraprestação ou pagamento de preços ou tarifas pelo usuário $\left(\mathrm{CF}\right.$, art. $\left.150, \S 3^{\circ}\right)$, mas a atividade examinada, à qual se pleiteava imunidade, era desempenhada por entidade privada com intuito de exploração econômica; e (ii) o segundo fundamento relacionava-se a uma questão de ordem mais processual.

A agravante, Bela Vista Comércio de Produtos e Serviços Postais Ltda. alegava em seu favor: (i) superveniência de elemento novo, consistente no encurtamento do prazo para a realização da licitação que iria definir os novos franqueados da atividade postal; (ii) a orientação firmada pelo STF considerava taxativa a lista de serviços tributáveis com a incidência de ISS definida em normas gerais em matéria tributária; e (iii) registrou a existência de erro material na decisão. Pedia então a reforma da decisão para que fosse concedida a suspensão da exigibilidade do crédito tributário discutido nos autos do RE 505.220. O ministro relator Joaquim Barbosa acolheu o pedido para correção do erro material, tendo rejeitado as demais alegações. Foi acompanhado pela unanimidade da Turma sem quaisquer reservas.

A razão que o levou a assim decidir foi a seguinte: a decisão do Tribunal do Estado do Rio Grande do Sul tinha se fundamentado no exame da conformação do contrato de franquia, tendo concluído que o acordo entre as partes deixava claro tratar-se de agenciamento. Conforme o voto condutor do acórdão recorrido, explorado pelo ministro Joaquim Barbosa, a franquia não prestava serviços postais e/ou telemáticos, mas de agenciamento, “...colocando referidos no mercado mediante o recebimento de comissões da EBCT'. Diante disso, o ministro entendeu que eventual conhecimento e provimento do RE dependeria (i) da descaracterização do contrato de franquia postal como agenciamento; e (ii) do reconhecimento de que franquia postal não é serviço previsto na lista de serviços anexa ao DL n. ${ }^{\circ}$ 406/1968 ou da LC 87. Para ambos, segundo o ministro, seria necessário rever a interpretação da norma infraconstitucional, bem como reexaminar os fatos e provas, o que não poderia ser feito mediante agravo.

Em 13 de maio de 2009, o Plenário do STF julgou a Ação Cível Originária n. ${ }^{\circ}$ 765-1/RJ. A ECT pedia que o STF se pronunciasse pela inexigibilidade de cobrança pelo Estado do Rio de Janeiro do IPVA, e afastasse as sanções decorrentes do não-pagamento 
do tributo. Fundamentava seu pedido no fato de desempenhar atividades típicas de serviço público obrigatório e exclusivo. O Estado do Rio de Janeiro contestou a inicial sustentando a ausência de imunidade da autora, tendo em conta tratar-se de exploração de atividade econômica pelo Estado. A ação foi julgada procedente, por maioria de votos, vencidos os ministros Marco Aurélio e Ricardo Lewandowski, que a julgavam improcedente, e o ministro Joaquim Barbosa, que a julgava improcedente em parte. Podem-se verificar nos votos três linhas decisórias.

A primeira linha decisória relaciona-se aos votos dos ministros Marco Aurélio e Ricardo Lewandowski. O primeiro reproduziu seu entendimento, na mesma linha dos seus pronunciamentos anteriores. O segundo acolheu os fundamentos do voto do ministro Marco Aurélio (a imunidade do art. 150, II, "a" se aplicaria essencialmente a pessoas jurídicas de direito público; e em razão da previsão do art. $173, \S 2^{\circ}$ ), manifestando uma clara preocupação em relação à extensão da imunidade a empresas que exercem práticas de natureza tipicamente comercial.

Nesse sentido, partia de dois pontos de análise: (i) parte das atividades exercidas pela ECT corresponderia efetivamente a serviço público, mas do seu ponto de vista, existiria uma outra parte, bastante considerável, que visaria apenas o lucro, tal como se fosse uma empresa privada; e (ii) o serviço da ECT é franqueado. Segundo ele, existiriam quase 1.500 franquias da ECT distribuídas por cerca de 500 municípios em todo o Brasil, e lhe causava perplexidade o fato de o STF estar concedendo imunidade a elas. Com isso, o STF estaria terceirizando a imunidade constitucional para acobertar uma atividade de caráter nitidamente privado e comercial: "[t]odos os seus veículos estão isentos de IPVA, $e$ suas atividades estariam isentas dos impostos dos demais entes federais. Isso me causa perplexidade...". Para o ministro, as franqueadas não estariam compreendidas nessa imunidade.

A segunda linha decisória relaciona-se ao voto do ministro Joaquim Barbosa. Segundo ele, é necessário considerar o que chama de natureza anfibiológica da ECT, pelo fato de ela exercer de um lado atividades típicas do Estado e de outro atividades econômicas (dizia ele: “Ela tem, inclusive, um banco, não é?"). Por essa razão, ele considerava necessário que o ente tributante fizesse essa distinção no momento de exercer o seu poder tributário. Julgou com isso parcialmente procedente a ação, por abrir a “...possibilidade de o ente tributante fazer essa triagem entre o que é afetado ao serviço 
eminentemente postal e o que é atividade econômica". Segundo ele, ao atuar como empresa privada, a ECT deveria se submeter às regras de direito tributário.

A terceira linha decisória, majoritária, foi conduzida pelo voto do ministro Eros Grau, segundo o qual o art. 173 claramente se aplica única e exclusivamente a empresas estatais exploradoras de atividade econômica, e segundo ele “...a Empresa Brasileira de Correios e Telégrafos é uma empresa prestadora de serviço público. Está previsto no art. 21 da Constituição". Quanto à extensão do privilégio às franquias, o ministro entendeu que elas de forma alguma descaracterizam o serviço público. Segundo ele: "Se eu pensar na cidade de São Paulo (...) lá há uma empresa concessionária (...) chamava-se MTC, que tinha uma série de franqueados e permitia a outras empresas a prestação do serviço (...). São como empresas franqueadas, sem que isso absolutamente descaracterize o serviço público que (...) é serviço público por definição constitucional...”.

Em linha assemelhada são os votos dos ministros Carlos Ayres e Cezar Peluso. O primeiro chamava atenção para o fato de que quando uma empresa como a ECT obtém lucro, ela não faz do lucro um fim, pois ela o obtém para continuar prestando a atividade. O ministro Cezar Peluso, por sua vez, enfatizava não ser possível estabelecer a priori, nem empiricamente, nenhuma distinção sobre a propriedade dos bens porque se todos eles fossem subtraídos da empresa, ela não poderia desempenhar a prestação de serviço público que lhe foi atribuída.

A partir do voto do ministro Ricardo Lewandowski, os ministros discutiram se a imunidade também se estenderia às agências franqueadas, mas o STF acabou não se pronunciando em relação ao tema, concluindo que não estava sendo discutido no caso. A partir do voto do ministro Joaquim Barbosa, os ministros também discutiram se seria possível discriminar para quais serviços a ECT utilizaria os veículos. A ministra Ellen Gracie ponderava que o IPVA é atribuído a débito de quem é proprietário do veículo (a ECT), não fazendo parte da hipótese de incidência tributária a forma como ela se utilizará do veículo.

Em 20 de outubro de 2009, a Primeira Turma do STF julgou o Ag. Reg. no Agravo

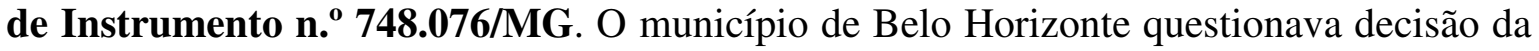
ministra Cármen Lúcia, que havia negado seguimento a agravo de instrumento por ele interposto contra decisão que não havia admitido recurso extraordinário contra julgado do Tribunal Regional Federal, que havia conferido à ECT direito à imunidade tributária recíproca prevista no art. 150, VI, “a” da Constituição. 
O município alegava que (i) a questão da imunidade discutida ainda deveria aguardar solução definitiva da ADPF n. ${ }^{\circ}$ 46-7/DF, na qual se analisaria a natureza jurídica do conceito de serviços postais, definições que seriam essenciais para o encerramento do recurso, em que se buscava limitar a imunidade da ECT aos bens e serviços utilizados na prestação de serviço público em caráter de monopólio; e (ii) ainda que o Tribunal reconhecesse a imunidade em favor da ECT, ela não poderia ser geral e irrestrita, devendo limitar-se aos bens e serviços vinculados à prestação do serviço público postal monopolista, não atingindo outros serviços realizados pela empresa em regime absolutamente concorrencial.

A ministra Cármen Lúcia, relatora, negou provimento ao agravo regimental sob os seguintes fundamentos: (i) a ADPF n. ${ }^{\circ} 46$ tinha por objeto a verificação da recepção da lei n. ${ }^{\circ}$ 6.538/78, que havia instituído o monopólio das atividades postais, matéria que segundo ela era totalmente diversa da imunidade tributária recíproca; e (ii) o STF havia firmado entendimento segundo o qual as empresas públicas diferenciam-se das empresas que exercem atividade econômica. A ministra foi acompanhada pela maioria da Turma, tendo sido vencido o ministro Marco Aurélio, que entendia que a imunidade do art. 150, VI, "a" da CF apenas alcança pessoa jurídica de direito público.

No mesmo dia, a Primeira Turma do STF também julgou o Ag. Reg. no Recurso Extraordinário n. ${ }^{\circ} \mathbf{5 5 2 . 7 3 6 / R S}$, através do qual o município de Porto Alegre também questionava decisão da ministra Cármen Lúcia, que havia negado seguimento a agravo de instrumento por ele interposto contra decisão que não havia admitido recurso extraordinário contra julgado do Tribunal Regional Federal, que havia conferido à ECT direito à imunidade tributária recíproca prevista no art. 150, VI, “a” da Constituição.

O município questionava a decisão alegando que, nos termos do art. $150, \S 3^{\circ}$ da Constituição, não se poderia aplicar a imunidade tributária aos casos em que se tem exploração de atividades econômicas regidas pelas normas aplicáveis a empreendimentos privados ou quando haja contraprestação ou pagamentos de preços ou tarifas pelo usuário. Segundo o município, a ECT recebia preço ou tarifa do usuário do serviço, como remuneração. Alegava ainda que a ADPF n. 46 estava sendo julgada pelo STF, e nela estava sendo discutida a controvérsia sobre a natureza jurídica dos Correios.

A ministra Cármen Lúcia, relatora, negou provimento ao agravo regimental sob o fundamento de que o STF já tinha reconhecido à ECT imunidade tributária, por oferecer serviço público cuja prestação é obrigatória e exclusiva do Estado. Foi acompanhada pela 
maioria da Turma, tendo sido vencido o ministro Marco Aurélio, que entendia que a imunidade do art. 150, VI, "a" da CF apenas alcança pessoa jurídica de direito público.

Em 06 de abril de 2010, a Segunda Turma do STF julgou o Ag. Reg. no Agravo de

Instrumento n. ${ }^{\circ}$ 518.325/RS, em que o município de São Leopoldo questionava decisão do ministro Joaquim Barbosa que havia negado seguimento a agravo de instrumento. Sustentava que a imunidade tributária recíproca só é aplicável ao contribuinte de fato e que deveria ser concedido o mesmo tratamento concedido à ECT. O ministro relator Joaquim Barbosa pronunciou-se contrariamente ao município. Foi negado seguimento ao agravo pela unanimidade dos ministros da Turma, que acompanharam o relator sem quaisquer reservas.

O ministro Joaquim Barbosa fundamentou seu voto nas seguintes razões: (i) o alcance da imunidade tributária recíproca é definido pela sua vocação para servir como salvaguarda do pacto federativo, para evitar pressões políticas entre entes federativos ou para desonerar atividades desprovidas de presunção de riqueza; (ii) a imunidade recíproca opera como um instrumento de proteção de instrumentalidades estatais, não podendo ter como efeito jurídico colateral o desequilíbrio das condições de concorrência econômica, nem o benefício de entidade particular, voltada à exploração econômica e lucrativa de qualquer objeto; (iii) a função da imunidade tributária não é permitir ao ente federado pura e simplesmente contratar serviços onerosos a preços inferiores aos praticados pelo mercado em geral; e (iv) os precedentes invocados pelo município não seriam aplicáveis ao caso, pois reconhecer a imunidade da ECT quando presta seus serviços não significa reconhecer a imunidade do ente público quando ele adquire bens em operações onerosas e que tem por objetivo o lucro.

Em 20 de abril de 2010, a Segunda Turma do STF julgou o Ag. Reg. no Recurso Extraordinário n. ${ }^{\circ}$ 443.648/RS, impetrado contra decisão do ministro Joaquim Barbosa, que havia entendido que não era possível deixar de aplicar a imunidade se o ente tributante não especificasse o modo pelo qual os serviços, a renda ou o patrimônio da ECT não estavam sendo aplicados na execução dos serviços públicos que justificavam a imunidade recíproca. Nas palavras do ministro, “...compete ao ente tributante identificar com precisão os critérios que descaracterizariam as atividades da autora como públicas, no caso concreto". O município de Porto Alegre sustentava que a ECT não poderia ser beneficiária da imunidade recíproca por ser entidade que desempenha atividade econômica insuscetível de receber benefícios não extensíveis à iniciativa privada (art. 173, CF). Nos termos do 
voto do ministro relator, a Segunda Turma do STF, em votação unânime, negou provimento ao agravo regimental.

O ministro Joaquim Barbosa fundamentou sua decisão nas seguintes razões: (i) o STF havia consolidado orientação segundo a qual a ECT é beneficiária da imunidade recíproca (art. 150, VI, "a" da CF); (ii) o ponto que segundo ele ainda estava pendente de definição relacionava-se à extensão da imunidade ao patrimônio, renda ou serviços estranhos à atividade principal da entidade, matéria que segundo ele seria enfrentada nos autos do RE n. ${ }^{\circ}$ 601.392; e (iii) no caso em análise, a parte agravante não fazia distinção entre as atividades protegidas pela imunidade e as atividades de exclusivo interesse privado-econômico, o que o afastava da decisão do RE. Segundo ele, questionava-se apenas a inaplicação total da imunidade recíproca à atividade postal, tese que já havia sido rechaçada pelo STF.

Em 04 de dezembro de 2009, foi publicado o julgamento da Repercussão Geral em Recurso Extraordinário n. ${ }^{\circ}$ 601.392/PR. Um recurso extraordinário havia sido interposto contra acórdão do TRF da $4^{\mathrm{a}}$ Região, de acordo com o qual a imunidade tributária da qual a ECT era beneficiária restringia-se aos serviços tipicamente postais mencionados no art. $9^{\circ}$ da lei n. $^{\circ} 6.538 / 78$, razão pela qual o município poderia cobrar Imposto sobre Serviços (ISS) relativamente aos serviços não abarcados pelo monopólio concedido pela União, que também são realizados por empresas da iniciativa privada. A ECT recorreu da decisão sustentando que (i) a imunidade deve alcançar todas as atividades postais realizadas pela empresa; (ii) executa serviços próprios da União e correlatos, de modo permanente e sem fins lucrativos, arcando com despesas não cobertas pelo preço cobrado nas postagens; (iii) há risco de prejuízo à prestação dos serviços postais, caso haja a obrigatoriedade de recolhimento do ISS; ressaltava estarem em jogo milhões e milhões de reais. Esse recurso extraordinário pende de julgamento final.

Em $1^{\text {o }}$ de setembro de 2010, o Plenário do STF julgou a Ação Cível Originária n. ${ }^{\circ}$ 789/PI, em que a ECT pediu que o Tribunal se pronunciasse no sentido da inexigibilidade, pelo Estado do Piauí, do IPVA e do afastamento de sanções decorrentes do não-pagamento do tributo, considerado o desempenho de atividades típicas de serviço público obrigatório e exclusivo. O Estado do Piauí contestou a inicial, sustentando a ausência de imunidade da autora, tendo em conta tratar-se de exploração de atividade econômica pelo Estado.

O ministro Marco Aurélio, relator, alinhado aos seus pronunciamentos anteriores, julgou improcedente o pedido formulado, reiterando os fundamentos que utilizou no 
julgamento da ACO n. ${ }^{\circ}$ 959-4/RN. Em sentido diverso, o ministro Dias Toffoli conduziu a corrente majoritária, pela procedência do pedido para declarar a inexistência, por parte da autora, do dever de recolhimento do IPVA relativo aos veículos de sua propriedade, restando definitiva a decisão de antecipação da tutela.

Suas razões de decidir foram as seguintes: (i) a jurisprudência do STF, desde o julgamento do RE n. ${ }^{\circ}$ 407.099/RS firmou-se no sentido de que a ECT, empresa pública prestadora de serviço público, é beneficiária da imunidade tributária recíproca $(\mathrm{CF}$, art. 150, VI, “a”), entendimento que foi confirmado na ACO n. ${ }^{\circ} 765 / \mathrm{RJ}$; (ii) por ser a ECT empresa pública prestadora de serviço público em regime de privilégio decorre seu ingresso no âmbito de incidência do $\S 2^{\circ}$ do art. 150 da CF; (iii) no julgamento da ADPF n. ${ }^{\circ}$ 46 confirmou-se que a ECT é prestadora de serviço público em regime de exclusividade, estando fora do regime de "monopólio" encomendas e impressos, e debateu-se a distinção das atividades exercidas pela autora que teriam nítida natureza econômica, a demandar certa ponderação quanto à espécie de patrimônio, renda e serviços protegidos pela imunidade recíproca; (iv) apesar da $\mathrm{ADPF}$ n. ${ }^{\circ} 46$ não há óbice à integral aplicação ao presente caso do mesmo entendimento firmado no julgamento da ACO 765/RJ, oportunidade em que o Tribunal entendeu que no caso de imunidade tributária relativa ao IPVA, como este, não caberia fazer distinção entre os veículos afetados ao serviço eminentemente postal e o que seria de atividade econômica; (v) “...entendo não haver necessidade de mudança de entendimento desta Corte, em especial quanto ao IPVA, pois, independentemente de estar ou não o veículo afetado ao serviço eminentemente postal, a ECT permanece como empresa pública constituída para a prestação dos serviços de que cuida o art. 21, X, da Constituição Federal, e, como assentado na jurisprudência específica desta Suprema Corte, faz jus à imunidade tributária prevista no art. 150, VI, ' $a$ ', e $\$ 2^{\circ}$, da Carta Magna"; (vi) a questão retornará à discussão do Plenário quando do julgamento do RE n. ${ }^{\circ}$ 601.392/PR, com repercussão geral conhecida, que versa sobre a definição da extensão da imunidade tributária ao patrimônio, renda ou serviços estranhos à atividade principal da ECT, mas aborda apenas o Imposto sobre Serviços (ISS), o que o diferencia essencialmente do presente caso.

O ministro Dias Toffoli foi acompanhado pela ministra Cármen Lúcia sem quaisquer reservas. O ministro Ayres Britto também acompanhou a divergência, salientando que "Trata-se de manter um serviço público - não é só de prestar -, a União 
tem o dever de prestar esse serviço, porque usou da expressão 'manter' o serviço, o que se vai refletir até na modicidade dos custos das tarifas dos correios".

Ao final, o Tribunal, por maioria, julgou procedente a ação, contra o voto do ministro Marco Aurélio.

Em 17 de novembro de 2011, o Plenário do STF julgou o Ag. Reg. na Ação Cível Originária n. ${ }^{\circ}$ 819/SE, interposto pelo Estado de Sergipe em face de decisão do ministro Menezes Direito em que ele julgou procedente o pedido de reconhecimento do gozo pela ECT da imunidade recíproca ( $\mathrm{CF}$, art. 150, VI, "a"). Fundamentalmente, o Estado de Sergipe buscava afastar a incidência da cobrança do Imposto sobre a Propriedade de Veículos Automotores (IPVA), no âmbito daquele ente federativo. No mérito, alegava que a decisão deveria ser reformada por ter partido do pressuposto da prestação exclusiva de serviço público pela empresa, quando esta também desempenha atividades de conteúdo econômico não abrangidas pela imunidade.

O ministro Dias Toffoli, relator, negou provimento ao agravo, destacando, quanto ao mérito, que a concessão de imunidade tributária à ECT é matéria que resta amplamente difundida nesta Corte, entendimento que foi reafirmado na ACO n. ${ }^{\circ}$ 789/PI, cujo pronunciamento reproduziu. Ao final, o Tribunal por unanimidade negou provimento ao agravo regimental, sem quaisquer reservas.

Em 26 de maio de 2011 o Plenário do STF julgou a Repercussão Geral no Recurso Extraordinário n. ${ }^{\circ}$ 627.051/PE. A ECT havia interposto recurso extraordinário questionando decisão do TRF da $5^{\mathrm{a}}$ Região, segundo a qual, por ser a ECT pessoa jurídica de direito privado, se sujeita às mesmas obrigações tributárias que as empresas privadas, razão pela qual deve incidir ICMS sobre o transporte de mercadorias que realiza, por não estar protegida pela imunidade constitucional. Em seu favor, a ECT alegou violação ao disposto no art. 150, VI, "a" da CF, sustentando que, com base na jurisprudência do STF, a imunidade tributária que lhe é atribuída é geral e irrestrita, aplicável a todo e qualquer imposto estadual. Defendeu que a atividade de transporte de encomendas não pode ser alvo de incidência de ICMS, pois faz parte do ciclo que compõe a atividade postal. Neste sentido, para fins de fixação da imunidade tributária, não interessaria qual serviço está sendo prestado pela recorrente, pois todos os recursos obtidos pela ECT serão revertidos em favor do serviço postal, destinado à coletividade. Em preliminar de repercussão geral, procurou demonstrar a repercussão da matéria. 
O ministro Dias Toffoli, relator, manifestou-se pela existência de repercussão geral da questão constitucional suscitada, no que foi acompanhado pelos demais ministros. Chamou atenção para a necessidade de o Plenário do STF enfrentar definitivamente a questão relativa à imunidade recíproca no que diz respeito ao ICMS e à sua incidência nos serviços de transporte prestados pela ECT. Neste sentido, mencionou diversas decisões em que foram objeto de discussão no STF os limites da imunidade tributária deferida aos Correios. O ministro ainda ressaltou que a questão “...transcende os interesses das partes, com repercussão na esfera de direitos de todos os Estados da Federação, dada a natureza da empresa pública e dos serviços por ela prestados". Esse recurso extraordinário pende de julgamento final. 


\section{O CASO DO “MONOPÓLIO” POSTAL (ADPF N.` 46-7/DF)}

$1{ }^{\circ}$ Aspecto: Natureza jurídica e exclusividade da União na prestação do serviço postal

Em 05 de agosto de 2009, o Plenário do STF finalizou o julgamento da ADPF n. ${ }^{\circ}$ 46-7/DF, ajuizada pela Associação Brasileira de Empresas de Distribuição (ABRAED), contra a ECT. No caso a ABRAED pedia que os ministros julgassem a ação totalmente procedente a fim de se:

(i) "reconhecer a violação aos preceitos fundamentais da livre-iniciativa, da livre concorrência e do livre exercício de qualquer trabalho...";

(ii) "declarar (...) a inconstitucionalidade da lei 6.538/78, especialmente sobre a questão do monopólio de entrega de correspondências";

(iii) "...declarar o que se entende por carta, que por motivos de segurança e privacidade continuam sendo prerrogativas da argüida, restringindo tal conceito de carta ao papel escrito, metido em envoltório fechado, selado, que se envia de uma parte a outra, com conteúdo único, para comunicação entre pessoas distantes, contendo assuntos de natureza pessoal e dirigido, produzido por meio intelectual e não mecânico, excluídos expressamente deste conceito as conhecidas correspondências de mala direta, revistas, jornais e periódicos, encomendas, contas de luz, água e telefone e assemelhados, bem como objetos bancários como talões de cheques, cartões de crédito etc." (petição inicial, p. $36)$.

Por maioria de votos o STF julgou improcedente a ADPF e deu interpretação conforme ao art. 42 da lei n. ${ }^{\circ} 6.538 / 78$ para restringir a sua aplicação às atividades postais descritas no art. $9^{\circ}$ do referido diploma legal.

Em termos gerais, firmaram-se três posicionamentos: (i) uma posição que entende que o serviço postal deve ser privado (sustentada pelo ministro relator Marco Aurélio); (ii) uma posição, que prevaleceu no julgamento, conduzida pelo ministro Eros Grau, segundo a qual o serviço postal deve ser estatal (ministros Eros Grau, Joaquim Barbosa, Cezar Peluso, Ellen Gracie, Cármen Lúcia e Carlos Britto, cujo entendimento, questionado ao longo da decisão em razão do "empate" inicial ${ }^{290}$, se aproximou mais do voto do ministro Eros Grau); e (iii) uma terceira posição, intermediária (pela procedência parcial da ADPF,

\footnotetext{
${ }^{290}$ Por tratar-se de julgamento de ADPF, era necessária maioria de 6 votos, que foi obtida com o pronunciamento final do ministro Carlos Britto, pela improcedência da ação.
} 
em diferente extensão), de acordo com a qual alguns serviços devem permanecer sob a exclusividade da atividade estatal e outros podem ser delegados à iniciativa privada (representada pelos ministros Gilmar Mendes, Ricardo Lewandowski e Celso de Mello voto cujo inteiro teor não foi acostado aos autos).

\section{c.1) $1^{\text {a }}$ Posicãa: corrente minoritária (ministro Marco Aurélio):}

O ministro relator Marco Aurélio, voto vencido, acolheu o pedido da inicial para declarar que não foram recepcionados pela $\mathrm{CF} / 88$ os artigos da lei $n .^{\circ}$ 6.538/78 que disciplinaram o regime da prestação do serviço postal como monopólio da União. O entendimento do ministro respalda-se nas seguintes razões de ser: (i) desde a CF/1934 fixou-se entendimento segundo o qual cabia privativamente à União manter o serviço postal e a despeito de a proposição normativa não ter evoluído com o passar do tempo, o alcance do verbo "manter" se alterou (a lei n. ${ }^{\circ}$ 6.538/78 não foi recepcionada pela CF/88 em razão das mutações operadas no direito administrativo brasileiro, de acordo com as inovações perpetradas no que tange às limitações de participação do Estado na economia); (ii) o Estado interventor é ineficiente (p. ex., ineficiência das empresas estatais), razão pela qual o pêndulo retornou à iniciativa privada, o Estado deixou de ser o principal agente financiador do desenvolvimento econômico, e há uma maior intervenção estatal por meio da regulação (deve-se adotar o modelo de Estado gerencial, em que sua atuação se dá de forma subsidiária, ou seja, o que possa ser realizado de maneira satisfatória pelas empresas privadas não deve ser assumido pelo Estado); (iii) o serviço postal durante muito tempo foi executado pela União (e não somente mantido) porque não havia no país empresas com capacidade operacional e técnica suficientes para desenvolver com presteza e agilidade a entrega de correspondências por todo o território nacional (era um monopólio natural); (iv) os serviços postais enquadram-se no que o ministro denomina "terceiro setor", hipótese em que a atividade pode e deve ser prestada por particulares; (v) quando o legislador constituinte quis remeter à necessidade de exploração direta da atividade pelo Estado, o fez expressamente (art. 21, incisos XI, XII alíneas a, b, c, d, e, f), e a CF é exaustiva também no tocante à instituição do monopólio da atividade econômica (artigos 21, XXIII e 177), pelo que "Somente o intérprete mais criativo poderia concluir que o verbo 'manter', a compelir a União a assumir os ônus relativos aos serviços postais, significa na verdade 'prestação direta ou mediante delegação a empresa pública, em regime de reserva de mercado'. A prevalecer esse entendimento, é dado imaginar uma interpretação extensiva, no sentido de dizer que, onde na Constituição se lê 'manter', leia-se 'monopólio', o que é 
absolutamente risível"; (vi) manter significa um conjunto de serviços que devem ser garantidos necessariamente pela União, o que abrangeria inclusive eventual exigência de prestá-los diretamente, quando não houver interesse econômico suficiente à implementação da atividade em determinados pontos do território nacional - a atuação do Estado na atividade econômica deve ocorrer apenas quando esta se mostrar falha ou insuficiente, de modo que o poder público aja de maneira a corrigir as imperfeições que o mercado sozinho não for capaz de corrigir; (vii) não há qualquer menção na $\mathrm{CF} / 88$ ao monopólio na prestação de serviços postais, e quando a lei foi editada em 1978 atendia-se a previsão da $\mathrm{CF} / 67$, repetida na EC n. ${ }^{\circ}$ 1/69, no sentido de que a legislação infraconstitucional poderia fixar monopólios, isto porque naquela época a atuação estatal na economia não se fazia de forma subsidiária; (viii) não se pode admitir que a liberdade de iniciativa conviva com o monopólio, sendo possível conviverem diferentes regimes de realização da atividade: “ $E$ preciso avançar e superar esse dilema que, na essência, apresenta-se falso, haja vista a possibilidade de conviverem diferentes regimes de realização da atividade: a prestação subordinada ao regime público, sujeita à observância dos princípios de universalidade e de continuidade do serviço, em termos fixados em contratos de concessão ou permissão, com as garantias que lhe são peculiares, e a prestação subordinada ao regime privado, observando-se os princípios de liberdade de iniciativa e de concorrência, podendo ser submetida a um regime de autorização por parte do Poder Público, a depender do tipo de atividade desempenhada"; (ix) a controvérsia sobre os custos de universalização da atividade não necessariamente é resolvida através do mecanismo do subsídio cruzado; no setor de telecomunicações foi criado um Fundo de Universalização do Setor de Telecomunicações - FUST; (x) o PL n. ${ }^{\circ}$ 1.491/1999 idealiza outro cenário para o setor postal, nos moldes do setor de telecomunicações (Fundo de Universalização de Serviços Postais - FUSP, criação da Agência Nacional de Serviços de Correios como ente regulador, possibilidade de o serviço ser prestado tanto no regime público, quanto no regime privado); (xi) "Nenhuma atividade é, em si mesma, um serviço público. Tudo depende da maior ou menor intervenção que o Estado deseje realizar na atividade econômica"; (xii) experiências do direito comparado se utilizam de modelos diferentes do monopólio cuja prevalência quer fazer crer a ECT; (xiii) o sistema de franquias do Brasil serve como reforço de argumentação no sentido de que não se pode considerar o serviço postal como um serviço público exclusivo e monopolístico; mesmo o art. $175 \mathrm{CF}$ proibindo a delegação de serviço público sem que seja precedido de licitação, a ECT realizou entre 1990 e 1994 
quase dois mil contratos de franquia, talvez por perceber que não se tratava mais de serviço público; e (ix) por mais que se pretenda modernizar a ECT, a permanecerem as amarras que decorrem da submissão desta ao regime de direito público, no sistema de monopólio, os principais prejudicados serão certamente os consumidores finais.

\section{c.2) $2^{\mathrm{a}}$ Posicão: corrente majoritária (voto condutor do ministro Eros Grau):}

Foi condutor de posição oposta e vencedora o ministro Eros Grau que, com a maioria do Tribunal, julgou improcedente a ADPF. Em seu voto, o ministro partiu do entendimento segundo o qual a exposição atinente à atividade econômica em sentido estrito (voto do ministro Marco Aurélio) perde o sentido porque o serviço postal é serviço público: "De qualquer modo, o que está afirmado lá [em parecer acadêmico] e o que tenho afirmado, inclusive em trabalho acadêmico, é que o serviço postal é serviço público. Portanto, a premissa de que parte o argüente é equívoca. O serviço postal não consubstancia atividade econômica em sentido estrito, a ser explorada pela empresa privada. Por isso é que a argumentação em torno da livre-iniciativa e da livre concorrência acaba caindo no vazio, perde o sentido". Trata-se, segundo o ministro, de serviço público por definição constitucional, e de serviço a ser prestado exclusivamente pela União (a ECT atua e deve atuar em regime de exclusividade na prestação dos serviços que lhe incumbem).

Entende o ministro que é necessário apartar-se o regime de privilégio, de que se reveste a prestação dos serviços públicos, do regime de monopólio sob o qual, algumas vezes, a exploração de atividade econômica em sentido estrito é empreendida pelo Estado: "Monopólio é de atividade econômica em sentido estrito. Já a exclusividade da prestação dos serviços públicos é expressão de uma situação de privilégio". Afirma que os regimes jurídicos sob os quais são prestados os serviços públicos importam em que sua prestação seja desenvolvida sob privilégios, inclusive em regra o da exclusividade na prestação, o que inclusive torna atrativo para o setor privado a sua exploração em situação de concessão ou permissão.

Neste sentido, o ministro afirma que “...para que empresa privada pudesse ser admitida à prestação do serviço postal, que é serviço público, seria necessário que a Constituição dissesse que o serviço postal é livre à iniciativa privada, tal qual o fazem os artigos 199 e 209 em relação à saúde e à educação, os quais podem ser prestados independentemente de concessão ou permissão. Os artigos mencionados excepcionam o 
art. 175 para dizer que a prestação de serviços de saúde e educação são livres à iniciativa privada".

A partir daí, o ministro entende que "Quanto ao âmbito do serviço postal, está bem desenhado nos artigos $7^{\circ}$ e seguintes da lei $n .^{\circ}$ 6.538/78, também recebida pela Constituição de 1988". Ainda, afirma que o Estado deve atuar de maneira forte e não de forma subsidiária, de maneira que a evolução da tecnologia deve refletir-se na vigência da $\mathrm{CF} / 88$ em aprimoramento tecnológico da ECT. No que tange ao modelo de Estado, o ministro afirma: "No Brasil (...) exige-se, muito ao contrário do que propõe o voto do Ministro relator, um Estado forte, vigoroso, capaz de assegurar a todos existência digna. A proposta de substituição do Estado pela sociedade civil, vale dizer, pelo mercado, é incompatível com a Constituição do Brasil e certamente não nos conduzirá a um bom destino".

Posição semelhante a do ministro Eros Grau foi a do ministro Joaquim Barbosa (voto vista), que também julgou improcedente o pedido. $\mathrm{O}$ ministro iniciou seu voto a partir das seguintes questões, que ele procura responder ao longo do voto: a) qual a definição do serviço postal, atividade econômica ou serviço público; e b) sendo ele considerado serviço público, se ele deve ser prestado em regime de privilégio da União, por meio da ECT, ou se pode ser delegado a terceiros e em que extensão. A partir dessas questões, o ministro expõe suas razões de decidir: (i) o serviço postal é serviço público, conforme doutrina majoritária e o art. $21, \mathrm{X}$ da $\mathrm{CF}$, do qual se extrai que a titularidade do serviço é evidentemente da União; (ii) o serviço postal é do interesse de toda a coletividade; (iii) ao se referir à competência da União de manter o serviço postal, a CF determina que cabe à União assegurar sua execução em todo o território nacional (dado corresponder a interesse coletivo significativo e ser fator importante da integração nacional); (iv) o serviço postal é prestado exclusivamente pelo Estado, em regime de privilégio, mediante outorga legal à ECT (o serviço não está elencado no art. 177 da CF por não se tratar de atividade econômica; serviço público exclui a ideia de monopólio); (v) as empresas filiadas à ABRAED não pretendem operar em todas as áreas em que atua a ECT e muito menos em todo o território nacional: "Querem essas empresas atuar apenas naquele setor mais lucrativo e de maior interesse econômico: entrega de documentos comerciais. Ressalte-se que o trabalho por elas efetuado restringe-se às grandes cidades e capitais do País, não alcançando municípios pequenos e distantes do centro econômico nacional"; (vi) o art. $9^{\circ}$ da lei n. ${ }^{\circ} 6.538 / 78$ estabelece as atividades a serem prestadas pela 
União em regime de privilégio e em seu art. 47 define claramente o que seja carta e, diante disso, "Não há como excluir desse conceito legal de carta os boletos bancários e notificações para cobrança de débitos, faturas de consumo de gás, luz e outras, bem como qualquer correspondência que contenha informação de interesse específico do destinatário, como o são quaisquer cobranças de débitos"; e (vii) cabe ao legislador o papel de estabelecer as hipóteses de prestação do serviço específico de entrega de correspondência comercial (no qual se inclui as cobranças de débitos) pela iniciativa privada, mediante contratos de concessão e permissão: “Entendo que a possibilidade de quebra do regime de privilégio em relação ao serviço específico de entrega de correspondência comercial (no qual incluo as cobranças de débitos) deve ser tratada pelo legislador ordinário, a quem cabe estabelecer as hipóteses de prestação desse serviço pela iniciativa privada, mediante contratos de concessão e permissão. Não cabe a esta Corte substituir o papel do legislador e fixar os critérios e formas para a prestação desse serviço público".

À esta corrente, pela improcedência total da ação, também se filiou o ministro Cezar Peluso. Entendeu o ministro que o serviço postal se trata de serviço público, pois tende a assegurar a comunicabilidade como condição necessária não apenas à integração, mas também à coesão nacional, e que a qualificação dogmática de privilégio pode ser bem aplicada a este caso.

No mesmo sentido, pela improcedência do pedido, foi o voto vista da ministra Ellen Gracie. Inicialmente, afirma que a ação não merece ser conhecida: “...sob o disfarce de agressão aos princípios constitucionais da livre concorrência e da liberdade de iniciativa o que pretende a arguente é que se lhe atribua a parcela menos penosa e mais rentável do mercado de entregas de correspondência, o que se faria mediante leitura reducionista do texto constitucional, quando refere a serviço postal, para dele excluir tudo que não fosse correspondência privada e confidencial. O conhecimento desse pedido leva a uma vulgarização do nobre instituto da ADPF que a Corte, segundo me parece, deveria evitar, sob pena de desvirtuarem-se as finalidades para as quais o instituto foi concebido".

No mérito a ministra afirma que o serviço postal é serviço público e não atividade econômica em sentido estrito e por isso deixa de ser incluído no rol de monopólios do art. 177 da $\mathrm{CF}$, pois este diz respeito exclusivamente às atividades de cunho econômico. Segundo a ministra, trata-se de serviço que o constituinte confiou à União para que o mantivesse, com exclusividade, serviço que ela tem o dever de prestar em todo o território 
nacional e que exercita por delegação legal a uma empresa pública expressamente constituída para tal finalidade.

Em suas palavras, “...por não ser atividade econômica em sentido estrito é que não se lhe podem ser aplicados os princípios da livre concorrência e da livre-iniciativa, como pretende a arguente. Tudo porque o serviço público vem informado pelo princípio da supremacia do interesse público e, por isso, é mantido ainda em condições deficitárias, como é o caso da entrega de correspondências em locais remotos e de difícil acesso de novo vasto território nacional. Garantir condições de comunicabilidade e de remessa de mensagens ou objetos a todos os brasileiros é objetivo que responde a mais do que o simples interesse individual dos missivistas. Diz respeito aos superiores interesses da integração nacional".

À corrente conduzida pelo ministro Eros Grau também se filiou a ministra Cármen Lúcia: "Vou acompanhar a divergência, Ministro, por entender que o que foi posto, ao iniciar a divergência, pelo Ministro Eros Grau, rigorosamente no sentido de ser serviço público, como diria Pontes de Miranda, assim o é porque a Constituição assim o quer: que o serviço postal e o correio aéreo nacional sejam de competência da União e, nessa condição, exclui da submissão obrigatória os princípios que foram listados pela arguente neste caso, que seriam da livre-iniciativa e da livre concorrência, exatamente porque o regime jurídico aqui é diferenciado".

A ministra ainda se refere à realidade do setor postal, mas em alguma medida a desconsidera: "Farei juntar voto no sentido de acompanhar integralmente a expressão do Ministro Eros Grau, com a devida desculpa do Ministro-Relator. Mesmo com as ponderações de Vossa Excelência, quanto à dinâmica da vida, principalmente dessas novas formas de comunicação, eu diria que a Constituição não é imutável, pode ser mudada, que a própria lei, naquilo que ela especificamente estipulou como podendo ser, ou não cabendo no caso do artigo $9^{\circ}$, pode ser repassada por outra, mas, considerar não recepcionada nem dar interpretação conforme, não estou convencido disso".

\section{c.3) $3^{\text {a }}$ Posicão: corrente minoritária "intermediária" (voto condutor do ministro Gilmar Mendes): \\ Posição intermediária foi inaugurada pelo ministro Carlos Britto, que posteriormente alterou sua opinião. No seu pronunciamento final entendeu que as atividades postais são serviços públicos, reservados à competência da União.}


Em seu posicionamento inicial, pela procedência parcial da ação, afirma que essas atividades, além de serem de titularidade pública federal, correspondem ao único serviço público não passível de transpasse para a iniciativa privada, mediante os institutos da autorização, concessão ou permissão, e essa especificidade decorreria da destinação das atividades, qual seja, "...favorecer a comunicação privada entre as pessoas, a integração nacional e o sigilo da correspondência”. Porém, ao entender correspondência epistolar como “...uma comunicação de caráter rigorosamente privado entre pessoas no plano da privacidade...", conclui se estaria excluindo da exclusividade da União em prestar esse serviço os documentos e encomendas de caráter mercantil, esse seria o cerne da questão. Neste sentido, afirma: "Senhor Presidente, neste primeiro momento inclino-me por entender que essa exclusividade a qual me refiro circunscreve-se às atividades que impliquem comunicação privada e comunicação telegráfica. Aquilo que tiver caráter rigorosamente mercantil, comercial, eu excluiria dessa atividade da União. Então, julgo procedente em parte, para dizer (...) que a recepção da Lei n. ${ }^{\circ} 6.538 / 78$ pela Carta Magna de 88 se restringe às atividades relacionadas com entrega e envio de cartas, o que se chama tecnicamente de correspondência agrupada, e atividades correlatas, como fabricação e distribuição de selos".

A partir disso, trava-se uma discussão entre os ministros Nelson Jobim e Carlos Britto. O primeiro questiona "A parte rentável, que financia a entrega de cartas, pode ser privatizada?", ao que o segundo responde "Não entendi bem". Nelson Jobim então mostra seu ponto de vista divergente: "Porque o mecanismo tem financiamento cruzado, ou seja, se tira a parte rentável da empresa, inviabiliza-se a outra", ao que Carlos Britto responde "Digo o seguinte, o que tiver caráter nitidamente mercantil, eu excluiria. Julgo procedente em parte".

A esta posição intermediária (no sentido de que a lei foi recepcionada em parte) se filiou o ministro Gilmar Mendes. Às fls. 116-117 o ministro proferiu um voto inicial, posteriormente o julgamento foi suspenso em razão do pedido de vista do ministro Menezes Direito (que posteriormente afirmou sua suspeição), os autos retornaram a Presidência e o ministro Gilmar Mendes reajustou seu voto, em que fundamentalmente melhor explicitou suas razões de decidir, tendo adotado, no entanto a mesma decisão final, proferida desde o momento inicial. Decidiu-se por: “a) julgar parcialmente procedente a arguição, fixando a interpretação de que a prestação exclusiva pela União da atividade postal limita-se ao conceito de carta, cartão-postal e correspondência agrupada, nos 
termos do art. $9^{\circ}$ da Lei $n .^{\circ}$ 6.538/78, não abarcando a distribuição de boletos (v.g. boletos bancários, contas de água, telefone, luz), jornais, livros, periódicos ou outros tipos de encomendas ou impressos; b) dar interpretação conforme ao art. 42 da Lei $n .^{\circ}$ 6.538/78 para restringir a sua aplicação às atividades postais descritas no art. $9^{\circ}$ do referido diploma legal".

Afirmou que o STF já se manifestou no sentido de que a ECT, no que se refere à atividade postal, presta serviço público e não atividade econômica em sentido estrito, e que o serviço postal (art. 21, X da CF) é serviço público, entendimento que se funda sobretudo em interpretação sistemática da Constituição. Mesmo considerando que a atividade postal é serviço público, entende que não há como negar o tratamento constitucional peculiar sobre esse tema, qual seja, o fato de diferentemente dos incisos XI e XII do art. $21 \mathrm{CF}$, o inciso X não fazer referência à exploração direta ou mediante concessão, permissão ou autorização da atividade.

A este respeito, o ministro afirma: "Entendo que a utilização do verbo 'manter', ao invés de 'explorar diretamente (...)', significa que a Constituição concedeu ao legislador ordinário alguma flexibilidade quanto à escolha adequada do modo pelo qual a Administração assegurará a prestação do serviço postal a toda sociedade. Não há como negar que o verbo manter, nesse contexto normativo, é mais abrangente do que 'explorar diretamente ou mediante autorização, concessão ou permissão'. Dessa forma, o legislador ordinário poderá, por exemplo, determinar que o serviço postal seja prestado por exploração direta pela Administração Pública; pela exploração indireta, mediante autorização, concessão ou permissão; ou por outros meios, inclusive a execução pela iniciativa privada, nos termos da legislação, mantendo a União o papel de ente regulador".

Destaca que a lei n. ${ }^{\circ}$ 9.074/95 (art. $1^{\circ}$, VII) dispõe que os serviços postais se sujeitam ao regime de concessão ou quando couber de permissão, e que a delegação do serviço postal é admissível, desde que o legislador assim discipline. Ademais, observa que o modelo de franquia postal é tratado na legislação (lei n. ${ }^{\circ} 11.668 / 08$ e decreto n. ${ }^{\circ}$ 6.639/08), de modo que, segundo entende, "Evidentemente, a franquia postal não se confunde com a clássica concessão e permissão de serviço público, o que já revela que o legislador pode dispor sobre a execução do serviço postal para além das hipóteses do art. 175, da CF, desde que respeitados os princípios constitucionais, especialmente os da Administração Pública". 
Diante disso, o ministro entende que quando a $\mathrm{CF}$ afirma que cabe à União manter o serviço postal e legislar sobre o tema (art. $21, \mathrm{X}$ c/c art. 22, V), a ela impõe o dever constitucional de proteger o núcleo essencial dessa atividade, "num contexto de complexa mutação das circunstâncias fáticas", em vista do que afirma: "Cabe à União, portanto, tendo em vista o contexto econômico, social e tecnológico, avaliar o modelo de prestação do serviço postal em determinado cenário, com vista a preservar a universalidade $e$ eficiência desse serviço público".

Partindo dessas formulações e do significado da exclusividade na prestação da atividade previsto no art. $9^{\circ}$ da lei n. $^{\circ} 6.538 / 78$, o ministro reconhece que é possível diferenciar "carta", "cartão-postal" e "correspondência agrupada" dos conceitos de "encomenda" e "impresso", na medida em que a lei não os indicou entre as atividades sob monopólio da União, de modo que, interpretado o monopólio restritivamente, nem todos os serviços postais estão submetidos à prestação exclusiva da União. Dessa forma, de acordo com o ministro, “...a prestação exclusiva pela União da atividade postal limita-se ao conceito de carta, cartão-postal, correspondência agrupada e fabricação de selos, nos termos do art. $9^{\circ}$ da Lei $n^{\circ}$ 6.538/78, não abarcando a distribuição de boletos (v.g. boletos bancários, contas de água, telefone, luz), jornais e periódicos, os quais se inserem na noção de 'encomenda' ou 'impresso' e não são indicados no referido art. $9^{\circ}$ entre as atividades de prestação exclusiva ('monopólio') pela União".

Em seus posicionamentos iniciais, anteriores a este voto reajustado, o ministro Gilmar Mendes sinaliza uma preocupação com o distanciamento da lei em vista da realidade de prestação dos serviços por empresas privadas. A este respeito, manifesta-se no seguinte sentido: "Em relação à questão da recepção ou não, assumo uma posição intermediária, propondo uma interpretação conforme. Eu até bosquejava a ideia de que esta norma da Lei de 78 era compatível com a Constituição anterior. Parece que a própria evolução social e econômica estaria a sinalizar, aqui, um tipo de processo de inconstitucionalização. A própria dinâmica, hoje, dos serviços estaria a indicar a participação dos atores privados e uma certa obsolescência dos dispositivos, pelo menos se lidos na sua literalidade estrita. Eu não consigo imaginar, por exemplo, que nós possamos invocar essa ideia do serviço público monopolístico para a entrega dos jornais, que se faz em geral, hoje, às cinco horas da manhã, e dizer que toda essa atividade, hoje realizada por empresas privadas, tivesse que ser desempenhada exclusivamente pela Empresa Brasileira de Correios e Telégrafos. Parece que isso está sendo revisto pela 
realidade, imaginando a sociedade aberta dos intérpretes da Constituição". A essas ideias o ministro Marco Aurélio acrescenta: "De reserva de mercado".

A partir disso, trava-se uma discussão entre os ministros Gilmar Mendes e Marco Aurélio, voltada a este problema da realidade setorial, discrepante da legislação, ou ao menos da interpretação que lhe tem sido dada. Diz Gilmar Mendes, complementando a ideia de Marco Aurélio: "Sim; ou a dizer que todas essas atividades que se exercem universalmente no Brasil são exercidas de forma ilícita, porque essa seria a outra conclusão". Completa Marco Aurélio: "Exato. Se assentado o monopólio, a exclusividade, de forma linear quanto à Empresa Brasileira de Correios e Telégrafos, na prestação de serviço, ter-se-á a clandestinidade". Gilmar Mendes: "Quer dizer, se essa atividade é ilícita, é clandestina, teremos que ver. Veja, realmente frustrando uma atividade que é dinâmica, e ninguém imagina que seja necessária para a sociedade, pelo contrário, nós perderíamos talvez a eficiência". Marco Aurélio: "No que nós outros, acatando esse serviço, estaríamos contribuindo para a ilegalidade". Gilmar Mendes: "Se era de fato legítimo e constitucional, condizente até com o modelo anterior da Constituição, parece que a dinâmica dos tempos, a própria atividade plural do mercado fez um tipo de processo de inconstitucionalização". (...) Gilmar Mendes: "É o tipo de tema que está a demandar ou uma completa reinterpretação ou uma reconfiguração pelo legislador daquilo que se entende de manutenção do serviço postal. (...) Então, queria assentar essa conclusão provisória e essa perplexidade".

A partir desse posicionamento do ministro Gilmar Mendes e das discussões travadas, o ministro Carlos Britto (ainda filiado a sua posição inicial, intermediária), chama atenção para a necessidade de se definir o que seja serviço postal, o que, segundo ele, não o deixava confortável, a despeito de já ter proferido seu voto: “Com o voto de Vossa Excelência, robustece em mim a idéia de que realmente é preciso definir o que seja serviço postal. O que não se compreender na definição de serviço postal está fora do conceito de serviço público. Por isso que Vossa Excelência falou de boleto, de jornal. (...) Avancei no meu voto, talvez para preservar três bens jurídicos: a integração nacional, o sigilo da correspondência e a privacidade. Adiantei no meu voto isso. E realmente esse é um tema que me causa uma inquietação intelectual. Não me encontro ainda confortável, a despeito do magnífico voto de Vossa Excelência".

A posição intermediária, inaugurada pelo ministro Carlos Britto (que posteriormente mudou de entendimento) e à qual o ministro Gilmar Mendes se filiou, foi 
também adotada pelo ministro Ricardo Lewandowski, que considerou a ADPF parcialmente procedente, tendo dado uma interpretação conforme aos diferentes dispositivos impugnados, inclusive no que tange às sanções penais, relativamente à infringência das atividades exercidas sob o monopólio estatal. Segundo o ministro, " $E u$ entendo que a competência privativa da União para manter o serviço postal, nos termos do artigo 21, X, da Constituição Federal, não engloba a correspondência comercial e a entrega de encomendas. Esses serviços não estão, a meu ver, abrangidos pelo monopólio estatal, que se limita ao serviço postal stricto sensu, ou seja, à entrega de correspondência pessoal, inclusive ligada à garantia que a Constituição estabelece relativamente à inviolabilidade do sigilo da correspondência, das comunicações telegráficas, e à emissão de selos, etc., enquanto serviço público".

Considerando a realidade de prestação dos serviços postais, entende o ministro que “...estão fora do monopólio estatal a entrega de talões de cheque, de cartão de crédito, de cartões de cobrança, brindes, documentos, amostras trocadas entre empresas, jornais, revistas, impressos que constituem uma atividade tipicamente econômica, até porque uma solução em sentido contrário militaria contra a realidade já delineada no mundo globalizado. Eu entendo, também, que estão excluídas desse monopólio as entregas de encomendas, os serviços de 'courier', mesmo porque já convivem com o correio estatal, não só no Brasil como no exterior, há muitos anos, com êxito, empregando centenas de milhares de pessoas".

O ministro pondera ainda que a livre-iniciativa configura um dos fundamentos do Estado democrático de direito e deve servir de baliza para a interpretação de todos os outros dispositivos da Constituição, pelo que não se pode dar interpretação extensiva ao comando constitucional que estabelece o monopólio.

Ao final do julgamento, tendo os ministros proferido seus respectivos votos, criouse um impasse, que foi solucionado a partir de uma "aproximação" do voto do ministro Carlos Britto do voto do ministro Eros Grau, condutor. Carlos Britto: "O meu voto está muito mais próximo do Ministro Eros do que do Ministro Marco Aurélio, porque entendo que a atividade não é econômica, é típica de serviço público. (...) pela dinâmica da rejeição e da atração, ele é muito mais atraído pelo voto do Ministro Eros do que pelo voto de Vossa Excelência, porque entendo que o serviço é tipicamente público, exclusivo da União, que tem a obrigação de manter, e, assim, obedecer ao princípio constitucional da continuidade". 
Procurando conciliar seu posicionamento com o voto anteriormente proferido, o ministro afirma excluir do conceito de serviço postal as encomendas e, após o voto do ministro Gilmar Mendes, a entrega de impressos, como jornais, revistas e outros periódicos, para que a liberdade de imprensa não fique prejudicada, cerceada de alguma maneira. Esse seu entendimento o aproximaria mais do voto do ministro Eros Grau do que do ministro Marco Aurélio. Diz o ministro: “...eu excluiria do serviço postal exclusivamente as encomendas e os impressos e tudo o mais ficaria sob não monopólio, mas sob o serviço exclusivo da União". Afora encomendas e impressos, tudo o mais (p. ex. boletos de tributos) estaria no âmbito material de compreensão da dicção constitucional "serviço postal".

Segundo o ministro Carlos Britto, “...quando eu fiz aquele primeiro voto, eu tive o cuidado de explicitar que se tratava de um tema de difícil cognição, não só na prática, extremamente complexo, que levava a divergências radicais. Como à luz do próprio Direito, todos nós tínhamos dificuldade em precisar o alcance material dessa dicção constitucional 'serviço postal'. Está bem claro no meu primeiro voto. Depois disso, a Ministra Ellen Gracie trouxe um substancioso voto que me impressionou bastante, entre outras coisas, porque Sua Excelência falava de financiamento cruzado, dizendo que as receitas do serviço público, prestado pelos Correios e Telégrafos, se compensam, de sorte que algumas financiam outras". E prossegue o ministro: “...Assentei o regime juspublicístico do serviço e não o jusprivatístico, na linha do voto do Ministro Eros Grau. Eu nem sabia que na prática isso já estava excluído. Excluí, como efetivamente excluo, do âmbito material de incidência desta expressão 'serviço postal', os impressos, a partir do voto de Vossa Excelência, proferido anteontem, e contemplo aquela minha primeira preocupação: também afasto do âmbito de incidência as encomendas, ou seja, os volumes entregues para destinação a terceiros. Então, excluiria exclusivamente do meu voto ou do âmbito de incidência material dessa expressão constitucional 'serviço postal' tão-só os impressos e as encomendas". Gilmar Mendes: "Portanto, boletos, contas, Vossa Excelência deixaria no conceito de cartas?". Carlos Britto: "Deixaria”. Gilmar Mendes: "Na verdade, então, temos maioria no sentido da improcedência".

Diante dessas discussões e posicionamento, o advogado pondera que esses serviços referidos pelo ministro Carlos Britto (entrega de jornais, revistas, periódicos) já não integram o monopólio/exclusividade dos correios. No mesmo sentido foi o posicionamento da advogada Maria de Fátima Morais Seleme: “É uma questão apenas de fato, Excelência. 
Então, eu gostaria de rápidas palavras, deixar bastante explicitado que ao Correio cabe a prestação de serviço postal de correspondência, valores e encomendas. E que a Lei 6.538 apenas considerou como monopolizadas, expressão que não é a mais adequada, mas exclusivas da ECT, o recebimento, expedição, transporte e entrega de objetos de correspondência, ou seja, carta, cartão-postal e correspondência agrupada. 'Encomendas' é serviço postal, porque nós precisamos levar às vezes o medicamento para todo o Brasil, mas também pode ser feito pela iniciativa privada, e impressos: jornais, livros e periódicos não são monopolizados, têm apenas tratamento tarifário diferenciados. Então, nos Correios a prática e a lei nos autorizam a agir dessa forma. Nesse sentido, com autorização do Senhor Ministro, achei importante. 'Encomenda' é serviço postal, porque nós precisamos fazê-lo em todo o Brasil, mas não é monopolizado. (...) Não é exclusivo. E impresso também. Fazemos em todo o Brasil e com uma tarifa diferenciada porque se trata de jornais, periódicos, livros, etc. e nós não o fazemos com exclusividade. Apenas carta fechada ou aberta de interesse específico do destinatário, seja ela uma comunicação social, administrativa ou comercial".

$\underline{2^{\circ} \text { Aspecto: Persecução penal (extensão da aplicação do art. } 42 \text { da lei n. }{ }^{\circ} \text { 6.538/78) }}$

Ao final do julgamento, Ricardo Lewandowski propôs que o Tribunal se manifestasse acerca da questão da persecução penal - ponto anteriormente levantado pelo ministro Gilmar Mendes - pois seria ponto fundamental, por exemplo, manifestarem-se sobre se as empresas que entregam encomenda podem ou não ser objeto de persecução penal. Após longa discussão sobre se isso era ou não objeto do pedido, o Tribunal decidiu dar interpretação conforme ao art. 42 conjugadamente com o art. $9^{\circ}$ (restringindo sua aplicação exclusivamente no que concerne a cartas, cartões-postais e correspondência agrupada), para que se evitem situações de pouca clareza e insegurança jurídica.

Em seu reajustamento de voto, o ministro Gilmar Mendes trata especificamente deste aspecto. Em relação aos dispositivos da lei relativos a tipos penais, especialmente o art. 42, entende que deve lhe ser dada interpretação conforme, sendo possível restringir sua aplicação às hipóteses do art. $9^{\circ}$ da lei, na medida em que o "monopólio" ou regime de exclusividade é limitado a atividades postais específicas. Isso porque a circunstância do tipo penal - a caracterização do delito se dá mediante a técnica da exclusão, de modo que se a conduta não estiver permitida, então é delituosa - revela uma falta de precisão para saber se a conduta está autorizada, sendo também necessária uma interpretação quanto aos 
limites das hipóteses permissivas, antes do seu cotejo com as ações que motivaram a denúncia. Isso enfraqueceria sua função de garantia (taxatividade), em violação ao princípio da reserva legal estrita, pois o princípio da legalidade $\left(\mathrm{CF}\right.$, art. $5^{\circ}, \mathrm{XXXIX}, \mathrm{CP}$, art. $1^{\circ}$ ) apresenta desdobramentos, “...entre os quais se destaca a taxatividade, pela qual se reputa inconstitucional toda e qualquer lei penal que, de forma vaga, imprecisa, afaste do destinatário o entendimento de seu alcance”. 